\title{
КАЗАНСКИЙ
}

МЕДИЦИНСКИЙ

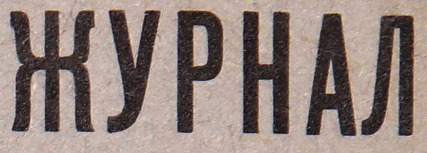

Издание Совета филиалов научных медицинских обществ Татарской ACCP

Орган Каванского государственного медицинского института и Казанского института усовершенствования врачей им. В. И. Аеяина

1937 r.

(Год издания XXXIII)

No 12

A E $K$ A $B$ P B

КАЗАНЬ 


\section{РЕДАК ПИЯ:}

заслуженный деятель науки проф. Е. М. Лепский (ответств. редактор), д-р Г. Г. Кондратьев (ответств. секретарь), проф. А. Н. Миславский, проф. В. К. Трутнев.

\section{В ЖУРНАЛЕ ПРИНИМАЮТ УЧАСТИЕ:}

Проф. А. Ф. Агафонов, проф. В. Е. Адамюк, проф. С. М. Алексеев, проф. М. П. Андреев, проф. 3. Н. Блюмштейн, проф. Л. М. Броуде, проф. И. П. Ва-сильев, засл. деят. науки проф А. Р. Вишневский, проф. Р. Р. Гельтцер, профБ. Г. Герцберг. доц. Б. С. Гинзбург, дощ. Д. Е. Гольдштейн, доц. М. И. Гольд. штейн, проф. Н. К. Горяев, засл. деят. науки проф. В. С. Груздев, проф. А. Д. Гусев, проф. В. А. Гусынин, проф. И. В. Домрачев, проф. А. В. Кибяков, доц. Л. Н. Клячкин, проф. И. Ф. Козлов, проф. Р. И. Лепская, проф. Б. Л. Мазур. проф. 3. И. Малкин, проф. П. В. Маненков, проф. М. И. Мастбаум, проф, В. К. Меньшико з, проф. В. В. Милославский, проф. А. Н. Мурзин, д-р М. В. Нежданов, проф. Г. М. Новиков, проф. Л. И. Омороков, проф. И. Н. Олесов проф. Я. Д. Печников, доц. Ю. А. Ратнер, проф. И. И. Русецкий, проф. Н. В Соколов, проф. А. Г. Терегулов, проф. В. Н. Терновский, доц. Л. И. Шулутко

Адрес редакции: Казань, ул. Толстого, № 14, тел. 34-02.

\section{Социалистическое здравоохранение, социальная и профессио- нальная гигиена, профпатология.}

С О Д Е Р Ж А И Е:

И. И. Попов и Р. М. Перчук (Одесса). Испытания сердечно-сосудистой системы у лиц, подверженных морской болезни.

А. А. Колачев (Шахты). О легочном раке у углекопов

\section{Клиническая и теоретическая медицина.}

3. Е. Отвиновская и Б. В. Успенский (Оренбург). Тифоподобные заболевания с палочкой Гертнера в крови . . . . . . . . . . .

Проф. С. В. Кофман (Ташкент). О ранних симптомах заболевания позвоночника туберкулезом .

B. В. Шкляев (Омск). Изолированный перелом ладьевидной кости запястья

Л. Е. Корыткин-Новиков и О. А. Бродский (Одесса). Хронические абсдессы грудной железы. .................. 1436

Проф. В. К. Трутнев (Казань). Об инородных телах трахеи и бронхов. . $14+2$

Проф. А. Б. Воловик (Ленинград). Ревматические пульмониты у детей. . 1448

Е. Н. Липовецкая (Саратов). Эндоназальный метод применения туберкулинотерапии у детей

С. М. Вяселева (Казань). К вопросу о влиянии активной иммунизации на носительство дифтерийных палочек

M. М. Золотарева и Н. И. Медведев (Сталино). К клинике retinitis albuminurica gravidarum.

П. И. Вахрамеев и Н. А. Борисов (Омск). Лечение переливанием крови помутнения стекловидного тела .

А. Н. Гордиенко и З. В. Старосветская (Краснодар). Влияние пищевого режима на феномен Артюса . . . . . . . . . . . . . . .

М. А. Ерзин (Казань). Динамика колебаний глютатиона при экспериментальных пороках сердца. 


\section{КАЗАНСНИЙ МЕДИЦИНСКИЙ ЖУРНАЛ No 12 AE $\mathrm{KA}$ Б P b \\ ГОА издания XXXIII \\ 1937}

\section{Сощиалистическое здравоохранение, социаљьная и профессиональная гигиена, профпатология.}

Нз отделения профессиональных болезней (завед. ㅍ-р И. И. Попов) Научноисследовательской лаборатории гигиены труда МСу Черного мори (завед. доц. M. Е. Медвелев).

\section{Испытания сердечно-сосудистой системы у лиц, подверженных морской болезни.}

\section{И. И. Попов и Р. М. Перчук.}

Морская болезнь (ж. б.), ироисходящая вследствие ряда неюбычных раздражений организма во нремя морской капки, складывается, как известно, главным образом из следуюцих симгтомов: головной боли, головокружения и слабости; затем наступают изменения в окраске лица-то гиперемия, то побледнение его, нелритные оцущения со стороны сердца (сердиебиение, замирание сердца), холодный пот, слюнотечение, икота, зевота и, наконец,-в наиболее резко выраженных случаях тошнота, рвота и общее состояние, напоминающее шок.

Таким образом, морская болезнь в основном слагается из симптомокомплекса аниионевротического типа.

Каков же патогенез этого симптомокомплекса? Существует ряд теорий, из которых ведуцими являются теории повышенной возбудимости вестибулярного аппарата (Квикса), раздражения блуждагшего нерьа (Фишера), анемии или гиперемия головпого мозга, шока (цит. у Прайора).

Большинство авторов, разрабатываюгци вопрос о патогенезе морской болезни, являютсл, однако, в этом вопросе односторонними. Они уцитывают лишь часть сложного симптомокомIллекса: придавая первенствующее значение рецепторной части рефлекторной дуги, они отодвигают на второй план значение еффферентной части этого слокного рефлекса. Наиболее иранильным нам кажется взгляд Брунса о едином рефлекториом процессе, при котором ненориальные ощущения качания через многие пути (оптиеские, кинестетические и др.) проводятся в центральную нервную систему и через нервные ядра вестибулярного aипарата переходят на связанные с последним центры блуждзюйего нерва и вазомоторные центры.

Грудно представить, чтобы у лиц, подверженных резкому укачиванию (морской болезни), были чрезмерно возбудимы лишь органы чувств, восприпимагцие идгередающие в цен- 
тральную нервную систему необычные раздражения от кацания судна; позтому необходимо а ргіогі долустить, что подверженные морской болезни-вообше легко возбудимые субъекты, внушаемые, с лабильной вегетативной нервной системой и резкими вазомоторными реакциями.

Проявления морской болезни испытынагот, как указывает Палеес, почти все люди, но резко болеюпих меньше; среди последних преобладают лица, главным образом, молодого возраста, женского пола; млденцы и старики знацительно менее лодвержены этой болезни. Среди заболевающих морской болезнью имеется много невропатов. В этом отношении напрашивается аналогия с болезнью летчиков, во многом схожей с морской болезнью. Рувинский, которому пришлось проводить профотбор в летные школы, счнтал 15\% обследуемых негодными из-за резкой возбуднмости их вестибулярного аппарата (реакцня Воячека), но в итоге забраковано было лишь 8\%, причем значительное больиинство-по состолнио нервной системь, главным образом, вследствие наличия ангионевроза. Интересен вывод автора, что как раз у подобных лиц вращение на кресле Барани вызывает сильную реакцню, что конституция их нервной системы-вегетативный невроз-находит свое отображение в лабильности отолитового аппарата.

Выявление подверженности морской болезни лиц, впервые лостулаюцих на водный транспорт, имеет большое значение, т. к. нередко уже принятые в морские школы в дальнейшезі вынуждены из-за этого покидать их. Поэтому мы поставили себе задатей выяспить, имеются ли какие-либо определенные пробы и признаки, на основании которых можно было бы заранее определить стелень подверженности того или иного субъекта морской болезни. С этой џелью в 1935-36 гу. мы лровели изучение более ста человек, подвергнув их клиническому обследованию и функциональным испытанням. Пронзведенные нами пробы связаны были с определением кровяного давления и счетом пульса как в спокойном состоянии, так и после физической нагрузки (в 20 приседаний); кроме этого, мы учитывали реакции пульса иі кровяного давления на раздражение вестибулярного аппарата качанием на качелях Хилова и вращением в кресле Барани, Полученные результаты испытаний мы сопоставляли со степенью выраженности укачивания (морской болезни), которая устанавливалась нами путем наблюдения за зтими лицами во время их практихеского 2--3-месячного плавания.

Возраст испытуемых был в пределах 17-25 лет, в среднем 20 лет; пол-мужской. У большинства плавательного стажа не было. Указанная однородность этой группы представляла несомненную ценность с точки зрения поставленной нами задачи; морская болезнь в этом возрасте зачастую резко выражена, а реакция на налрузки-наиболее демонстративна.

Рассматривая данные ислытаний, мы исходили из формулировки Ланга, согласно которой сердечно-сосудистую

скстему 
и иннервируюший ее отдел нервной системы нужно с точки зрения функции рассматривать вместе, как единый аппарат кровообрацения. Кроме этого, мы исходини из непригодности в этом отношении,-как показал нам и нащ опътразличных суммарных индексов (Лукомского, Мартине и др.), т. к. в обшем числовом индексе ис цезают ценные особенности реактивности на магрузку отдельно лульса, отдельно-колебаний кровяного давления и пр. Индекс Лукомского у наших испытуемых колебался между 2 и 7 , гоказывая этим функщиональную достаточность сердечно-сосудистой системы; лишь у одного он был ниже 1 (функциональная слабость), а у $4-$ свыше 8 (лица с резкой лабильностью реакций). Результат функциональных проб зависит не столько от максимальных возможностей серденно-сосудистой системы испытуемых, сколько от стелени физической тренированности, поцотовленности к нагрузке. Исходя из этого, мы уцитывали в результатах функциональных исыытаний лищь реакции пульса и кровяного давления на разлицные нагрузки.

Подверженные морской болезни были разбиты на 3 группы в зависимости от стелени укачиваемости; не дававшие признаков морской болезни отнесены к нулевой группе.

Среди 8 человек нулевой группы (т. е. вовсе не дававших симнтомов укачнвасмости) у одного испытуемого обнаружена недостаточность двустворчатого клапана; никаких ощущений расстройства деятельности сердца обследуемый не нслытывал, нсе фунциональные пробы были внолне удовтетворительны. у другого из этой группы обнаружена эссенциальная гипертония без всяких субьективных ощущений, с хорошими функциональными пробами. Очевидно, в обокх этих случаях сердечяососудистая система была хорошо адаптирована тонусом вегетативной нервной системы. Среди плавсостава имеются гинертоники и лица с пороками сердца, и мы не находим обыцно у них связи морской болезни с әтими заболеваниями. У остальных 6 человек нулевой группь никаких отклонений от нормы ни со стороны сердечно-сосудистой, ни со сторонь вегетативной системы не было обнаружено.

В 1-й группе, составленной из 24 человек со значительными прожнлениями морской болезни (головокружение, головная боль, слабость), 4 человека обнаружены с не вполне полноценной сердечно-сосудистой системой: характерны для них были нерезкие функциональные шумы, склоншость к небольшой тахикардии и одышке при нагрузке. У одного обнаружено вагусное сердще, брадикардия; последняя незначительно изменялась даже после нагрузки. У двух выявлена гипертония без особых функциональных нарушений. $У$ остальных лиц этой групны объективно никаких изменений не выльлено; лишь у некоторых функциональные щробы выпадали слегка пониженными, выражаясь, главным образом, в небольшой тахикардик при ортоклиностатинеской пробе или после нагрузки.

Во 2-ю групгу вошли 37 человек с более значителыным 
призаками морской болезни (кроме признаков 1 степени нзменение окраски лица, холодный пот, слюнотечение, икота, зевота). У 4 -вторичная миастения. У 7 человек выявлены гипиные гризнаку тақ наз, „юнопеского сердца“, т. е. легко возбудимого, склонного к резким переходам от замедленного или норыального пульса к тахикардин; несколько расплывцатый, иногда резистентный верхушешный толчок; расщепленный, нещистый, хлопающий 1 тон на верхупке, инолда-не строго локализованный мягкй систоличесқий шум. Эти лица эмотивны, с пекоторыми признаками эндокринонатии, часто-с небольшим увеличением цитовидной железы и другими признаками; у некогорых - склонность к субффебрильной температурс, не зависялей от инфекции. Все они практически здоровы, трудоспособны. У 4 человск-явления невроза сердца с ангионеврозом; 4 велонека-с явлениями транзиторной гипертонии. Кроме этого, у 3 чел. обнаружено вагусное сердце с явлениями гипотонии.

Третья іруппа объединяет 37 человек, отличавшихся резкими степеняи морской болезни (кроме признаков l и II степенейтоннота н рвота). Здесь мы имели 2 случая вторичной миастении сердца, 5-с т. н. "юношеским сердцем“, 2-c неврозами сердца c ангионеврозом, 7 случаев транзиторной гилертонии $c$ явленияи ангионсвроза, 6 сл. вагусного сердца с гипотонией, аниионеврозом.Функциональные пробы почти у всех указанных лиц выпали неудовлетворительно. Остальные из атой группы нередко давали те или иные функщиональные пробы пониженными.

А. Фушкциональные ислытания, связанные со с че 'т о пу ульса.

1. Тахи-брадикароия, орио-клиностатинеская проба с пульсок. Орто-клигостатнческую пробу мы считали шоложительной при учашении пульса свыше 12 ударов в минуту. Фарфель применял указанную пробу и сопоставлял со степенями отолитовой реакции по Воячеку (врацение в кресле Барани); при этом он находи. большее уцащение пульса при более ныраженной рсакцин.

Таблица 1.

Харакmер пульса и орто-клиностатическая проба в зависимости ом cmeneнu морской болезни.

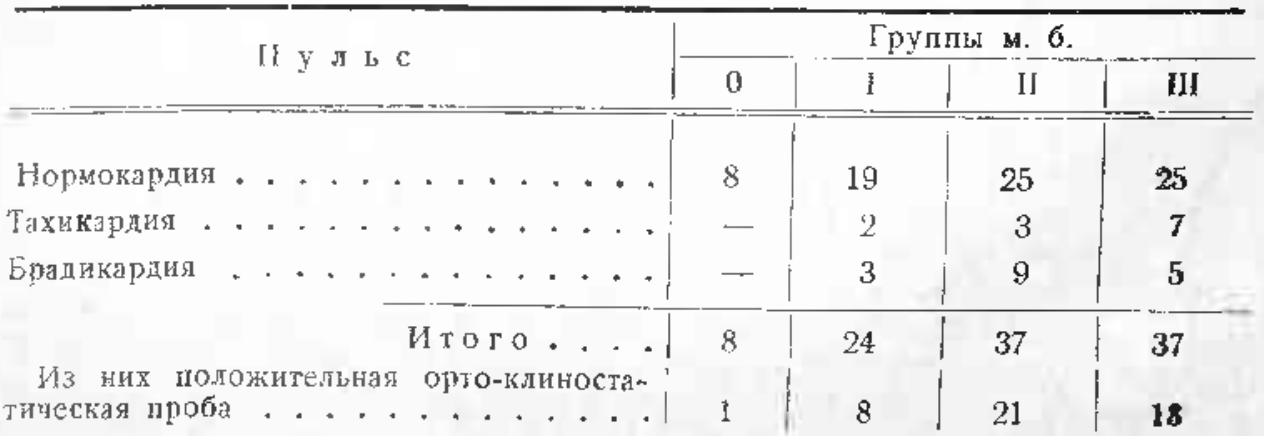


Интересно отметить, что орто-клиностатическая проба нерезко выражена в 0 и I группах, пульс ускорялся на 12-16 ударов, а в общем он был не чаще 96 в 1'. Во II и III группах проба нередко давала ускорение в 20-30 ударов, соответственно чему иульс ускорялся до 120 в $\mathbf{l}^{\prime}$, а в одном случае (III группа)-до I40.

Эти проб́ы показали, что с увеличением степени укачиваемости чаще встречаются случаи бради- и тахикардии, чаще выпадает положительной орто-клиностатическая проба.

2. Реакция пульса на нагрузку. Разниная мысль в том направления, что у лиц с выраженными степенями укачиваемости (H и IIl труппа) вообще возможна склонность отвечать на всякого рода раздражители большей частотой сердечных сокращений, мы выявили диапазоны пульса у испытуемых между состоннием его в спокойном положении и после физической нагрузки. В виде нагрузки цавалось 20 ритмичных приседаний в течение 50 секунд. Первый счет ироводился в горизонтальном положении обследуемого, второй также в горизонтальном, но тотчас после нагрузки. Так как нам важно было учесть реакщию, то мы во второв случае принимали счет шульса в течение ближайших после нагрузки 15 секунд.

Таблица 2.

Реакиия пульса на нагрузку в зависимости от степени . .6.

\begin{tabular}{|c|c|c|c|c|}
\hline \multirow[b]{2}{*}{ Реакции пульса } & \multicolumn{4}{|c|}{ Групвы м. 6.} \\
\hline & 0 & I & II & lal \\
\hline $\begin{array}{l}\text { Срсанее ускорение пульса после на- } \\
\text { грулки . . . . . . . . . . . . . }\end{array}$ & $310 / 0$ & $43 \%$ & $54^{\prime} / 0$ & $51^{0} ; 0$ \\
\hline 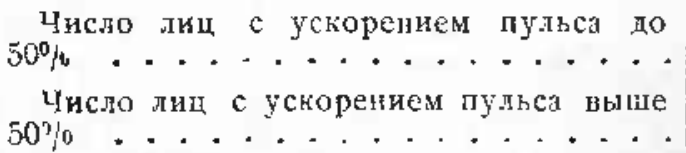 & $\begin{array}{l}8 \\
0\end{array}$ & 15 & 14 & 19 \\
\hline
\end{tabular}

Вo il группе все 9 человек с брадикардией дали наивысшие цифры ускорения: ни у одного из них не было ускорения ниже $50 \%$. В 1 II группе общий процент ускорения ниже, цем во Il групие за счет большего числа в зтой группе случаев с тахикардией, не дававших в общем ускорения ныше $50 \%$, и меньшего числа лиц с брадикардией, характерных резким ускорением пульса.

В результате мы видим, что с увеличением степени укачиваемости в болышинстне слудаев увеличивается учащение пульса носле нагрузки (II и Ill группы).

3. Время установки пульса после нагрузки. В функциональной диагностике, в частности относящейся к сердечно-сосудистой системе, имеет знацение не только величина реакции, но также и длительность ее. Проверни время восстановления пульса после указанной нагрузки в 20 приседаний, мы нашли следующее: 
Таблица 3.

Bремя установки пульса после нагрузки в зависимости от cmenemu $M .6$.

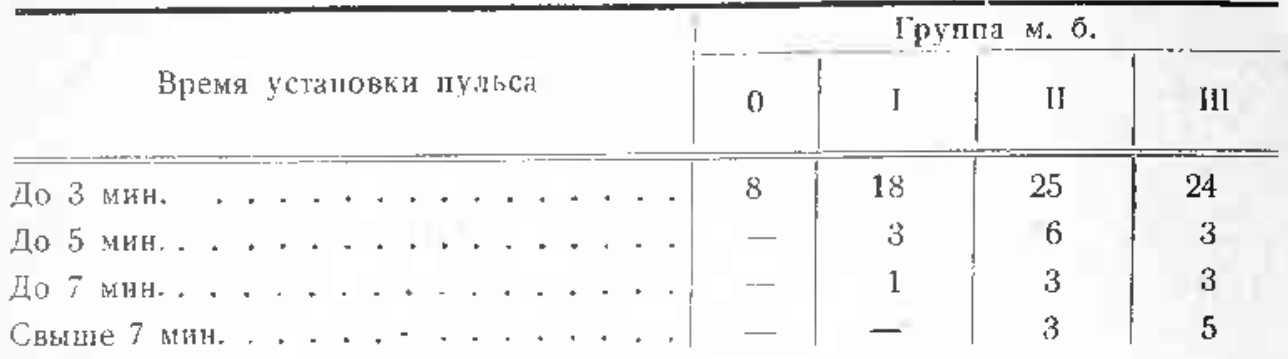

Следовательно, параллельно увеличению степени м. б. нередко увеличивалась у испғтуемых длительность восстановительного периода пульса после нагрузки.

Б. Функциональные испнтания, связанные сизмерением кровяного давления.

1. Кровнное давление мансимаяное, минимальное, алплатуда 6 спокойном состоянии ири горизонтальном положении. Мы сцитаем у наших испытуемых максимальное гіровлное давление нормальным в пределах от 105 до 130. Лиц с максимальным давлением ниже 105 сџитаем склоннымк ж гицотонии; при давлении выше 130-склонными к гипертонии. Как видно из таблицы 4, гипертоники встречаются почти одинаково часто во всех групиах. Разница лишь в том, что функииональные пробы у гинертонинов первых двух групп удовлетворительны, а в последних группах-неудовлетворительны. Но гипотоники уже чаще встречактся среди лиц II и III группы. В минимальном давлении обрапает на себя внимание резкое увеличение числа лиц с относительно повышенным минимальным давлением ( 80 и выше) в lll группе по сраннению с остальными. Случаи с пониженным минимальным давлением, т. е. ниже 50, не представляют особого интерсса, их вообце мало; то же можно сказать и об амплитуде выше 75. Броснется в глаза частота случаев понижения амплитуды ниже 50 среди лиц II и III групп.

В результате сопоставления данных кровяного давления во всех группах можно сказать, что гипертония сама по себе не вызывает склонности к морской болезни; лишь те гипертоникн подвержены укачиваемости, у которых функциональные пробы выпадают неполноценными. Гипотоники же чаще встречаются во II и III группах. Высокое минимальное давление, а равно и понижение амплитуды его также часто наблюдаются в III группе.

2. Кровяное давление максимальное, минимальное $и$ амплиmуда после нагрузки. По Кабанову, увеличение максимального и понижение минимаяьного давления после нагрузки-благоприятный фактор; одновременное повышение или понижение 
Кровяное давление и степени м. б.

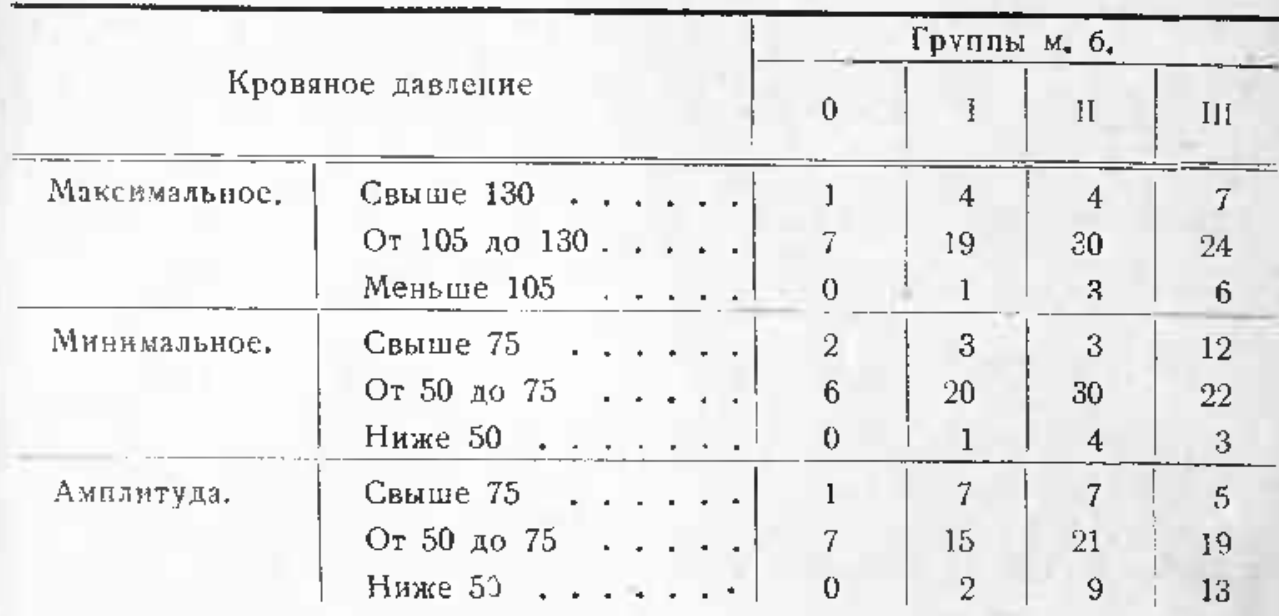

максимального и минимального давления-неблагоприятный; понижение максималыного и повышение минимального-плохой.

Средним максимальным кровяным давлением для наших испытуемых является $122 \mathrm{~mm} \mathrm{Hg}$, причем среднее повынение его после нагрузки в 20 приседаний равно $22 \mathrm{~mm} \mathrm{Hg}$, что составляет $\mathbf{1 8 \%} \%$. Среднее минимальное давление для всех обследуемых-63 mm Hg, тричем среднее понижение его для всех групп было $13 \mathrm{~mm} \mathrm{Hg}$ а в процентах--21\%

Таблица 5.

Кровяное давление после нагрузжи в зависимости от степени ж. 6 .

\begin{tabular}{|c|c|c|c|c|c|}
\hline & & \multicolumn{4}{|c|}{ Группы м. 6.} \\
\hline Kровяное & давление в $\% \%$ (средн.) & 0 & 1 & Il & III \\
\hline Максимальное & $\cdots \cdot \cdot$ & +20 & +16 & +19 & +17 \\
\hline Минимальное & ............... & -30 & -21 & -21 & -15 \\
\hline Амплитуда . & ........... & +76 & +64 & +66 & +52 \\
\hline
\end{tabular}

Из функционального испытания, результаты которого изображены на табл. 5, следует, что во всех 4 группах в ответ на нагрузку максимальное кровяное давление поднималось в одинаковой мере достаточно; если же взять из II и IH групи только гипертоников, то они дали в среднем сравнительно невысоки подаъем давления (11\%). Характерным для резко укачивающихся (III гр.) является относительно небольшое падение минимального давления (зачастую оно остается без изменения нли даже повышается) и относительно небольшой процент увеличения амплитуды.

3. Время восстановления кровяного давления после нагрузки. По аналогии с пульсом нас интересовало время установки кро- 
вяного давления после нагрузки во всех 4 группах. Если пульс, как правило, приходил к исходному, главным образом, между 1 и 3 минутами после иагрузки, то кровяное давление лишь в 2 случаях восстановилось на первой минуте, а в больиинстне слуцаев носстановление происходило между 3 и 5 минутами.

Таблица 6.

восстановление кровкного давления после нагрузки в зависимости от cmenени. . б.

Время восстановления кровяного давлсния

До 5 мин.

Цо 7 мин.

Не восстановияось до 7 -й мин.

Выводы из результатов этой пробш те, что кровяное давление так же, как и пульс во II и IlІ группах, в немалой части с.лучаев имеет склонность к более длительному восстановительному периоду после натрузки.

Суммируя все полученные данные фулкциональных испютаний, можно сказать, что для лиц, в зпачительной степени лгдверженных морской болезни, характерно некоторое ослабление функциональной сиособности сердецно-сосудистой системы и отсутствие тренированности ее; среди них часты случаи тахи-и брадикардин; эта браднкардия нестойка, после нагрузки резко переходит в тахикардию; даже орто-кииностатицеская проба часто изменяет эту брадикардию в тахикардию.

Мэйтлэнд, наблюдавший пульс у лиц, страдающих норскон̆ болезнью, говорит о симпатических и парасимпатических расстройствах, о чередовании их, так что часто труцно решить вопрос о типе расстройства; в наиболее прких случаях, говорит он, пульс бывает брадикардичен, с замедлением при вставании, или с все увеличиваюцейся тахикардией при вертикальном положении. После нагрузки пульс зачастук медленно восстанавливается. Все это может быть в достаточной мере объяснено дистонией ваго-симпатической нервной системь. Тем же ибълсняется повынение минимального давления и нестойость гипотонии. Эти результаты функционального испы'绍н: не противоречат клиническим данным.

В. Реакции пульса и кровяногодавления при раздражении вестибулярного аппарата.

В качестве раздражителей мы применяли искусственное раздражение вестибулярного алларата путем качания испытуемых на специально оборудованных качелях Хилова. В тех случаях, где мы этим не достигали нужного эффекта в смысле получения синдрома, тождестненного с морской болезнью, мы пользоа 
вались пелосредственно после качания вращением на кресле Барани. Теоретически эти раздражители отождествляются с некоторыми элементами воздействия на организм при морской качке.

1. Реакция пульса на качание и вращение. М. Фишер у $14 \%$ ислытуемых находил после вращения пульс без измененяя, у $40 \%$--ускорение и у $46^{\mathrm{j}} / 0-$ замедление. Флэк находил у опьтных пилотон малое изменение пульса после вращения на кресле, но в случаях головокружения, тошноты и рвоты-учашение его. Фарфсль у большинства ислытуемых находила учащение пульса носле врашения, причем оно было наибольцим у лиц с резко выраженными степенями отолитовой реакции.

Непосредственио до опыта с качанием и вращением мы сосчнтғндли у испытуемых пульс и определяли крөвяное давление в горизонтальном положении, причем это исследование производнлось в комнате, смежной с той, где находилось кресло, что нсключало возможность неточности в методиже, которую допустил $M$. Фишер.

В громадном большинстве случаев пульс реагировал на качание и врацение учащением числа ударов во всех 4 группах обследуемых, цричем средний процент ускорения равнялся 16. Но это учащение было не одинаковым в каждой из 4 групи (см. табл. 7). Из всех испытуемых 91 чел. дал учацение пульса, У 4 человек иульс оставался без изменения. У I3-замедлялся. Не изменялся пульс, а также в части случаев замедлялся, гл. образ., в 0 и 1 групиах. Особенно интересно, что из чаев с тахикардией в I и ll группах в 7 произошло замедғение пульса, и все они дали в среднем $3 \%$ замедления. Иначе реагировали 6 чел. с тахнкардией из III груплы: ни один из них не дал замедления, и средний эроцент ускоргния выразился у иих в 22. Только в III группе все 100\% обследуемых реагировали на эту пробу учащением пульса. Кроме того, необходимо подчеркнуть, что среди лид IIl группы в день пронзведения указанноц лробы выявлено 11 чел. с брадикардиец, в то время как мы ранес отметили (см. табл. 1) лишь 5 такнх случаев; все эти 11 чел. с брадикардией реагировали на иснытание резким учацением пульса и дали в среднем $32 \%$ ускорения. Между тем 8 чел. с брадикардией из лиц, отнесенньх к і и IIL групиам, показали учащение пульса лишь на 17\% в среднем.

Таблица 7.

Pеакции пульса на канание и вращение 8 зависимосли от cmeneнu $\%$. 6 .

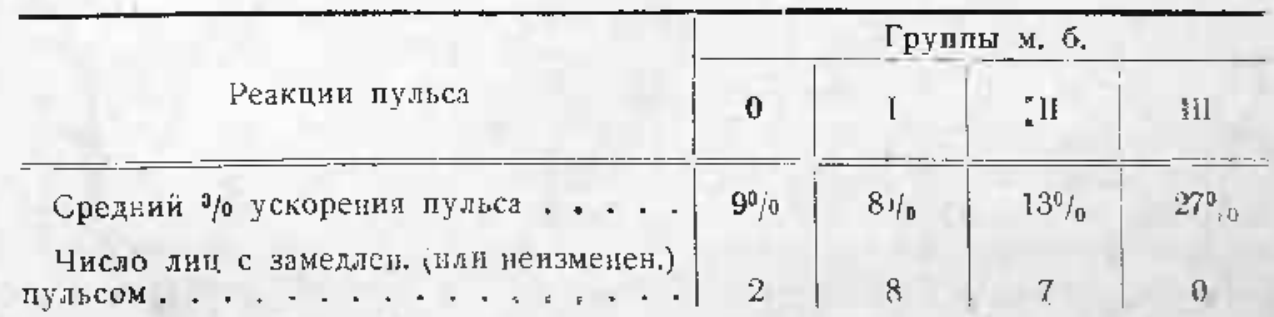


Отсюда бесспорно можно заключить, что лица с резкой стеленью подверженности м. б. (III гр.) характеркзуются резкой реакциё пупьса (в смисле ускорения его) на качание и вращение, дейстующие как раздражитель вестибулярного аппарата, наподобие качанио судна. Немалое число пиц из этой группы характеризуется своей нсустойчивостью в смлсле легкого перехода от замедлениото пульса к ускоренному. В III группе случаи с тахикардией характеризуются еще более резким ускорением пульса на указанное раздражегие.

2. Реакция кровяного давления на кашание-врашение. Кровяное да́лление согласно статистике, приведенной фарфель, по данным одних авторов уиеньшаетси, по мнению других-увеличивается после врашелия на кресле; Фарфель находила у большинства пспьтуемых увелитение кровяного давления, по тем меньцее, пем более резко выражсна стспень O. R. (отолитовой реакции); Флэк находил увеличение кровяного давления у лиц с резкнми степенями O. R.; M. Фишер в 55\% находил его понышенным, в 12\% -пониженым. Все это касается максимального данления. Минимальне и Фләк и Фарфель находили повлылащимся иосле вращения, причем последним автором отмечалась зависиность повышения давления от степени $O . R$.

Как пульс, так и кровяное давление измерялись до и тотчас носле испьтания на качелях н кресле. Максимальное кроняное павление прнблизительно одияаково нзменллось во всех четыpex rруппах (см. табл. 8); во всех 4 групाах имеется приблизительно одинаковое число случаев неизмененного или иониженного максимального давления (см. табл. 9). Юзменения же миниального давления после указанного исльтания совершенно различнғ для всех групп: у пиц из нулевой группы минимальное кровяное давление понизилось в среднем на $18^{\circ} / 0$, у первой груплы на $10 \%$, а $\mathrm{y}$ лиц из II груплы лроизошло понышение минимльного давления на $4 \%$, в لil групле повышение достигло 11\%. ІІараллельно с зтим в каждой последующей группе увеличнвалось и число лиц, рсагировавших на испытание повышением минимального данления. Соответственно изменениям максимального и минимального кровяного давления изменялась и амплитуда кровяного давления во всех 4 группах, причем в 0 группе все 8 чел. дали увеличение ее, выразившееся в среднем в $40 \%$; в I грушле среднее увеличение амплитуды равнялось $24 \%$, причем у 4 чел. амплитуда оставалась без изменений, во II группе среднее увеличение амплитуды выявлено в 12\%, причем из 37 обследуемых у 7 чел. амплитуда оставалась без изменения, у 11 понизилась; наконец в II группе это увеличение составляло для всех лишь $10 \%$ и из 37 чел. әтой группы 4 чег. вовсе не дали изменения амплитуды, а у 10 она понизилась.

Характерным для большого числа лиц с резкими степенями укачиваемости (II и ІІІ групшы) в зтом испытании является повышение минимальғого кровяного давления, сравнительно небольщое увелияение амплитуды кровяного давления и в немалом 
Таблица 8.

Реакиии кровяного давления на кацание и вращение в зависимости от сmеneни $\mathrm{s}$. 6 .

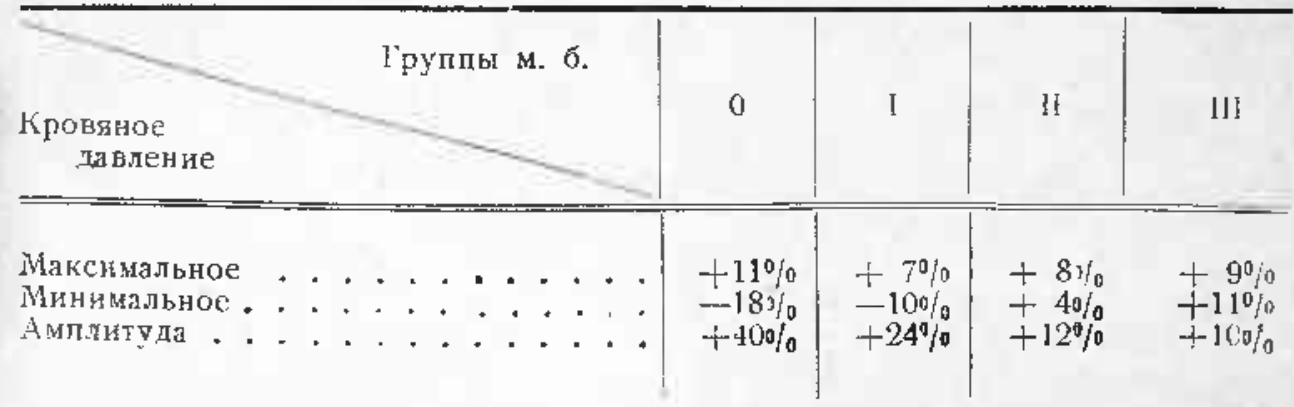

Таблица 9.

Реаквии кровяного давления на качание и враццение в зависимости от степени $\boldsymbol{\mu}$. 6 .

\begin{tabular}{|c|c|c|c|c|c|c|c|c|c|c|}
\hline \multirow[b]{2}{*}{ I"pyintix M. 6.} & \multirow[t]{2}{*}{$\begin{array}{r}\text { Реакции кров. давл. } \\
\text { (число случаев) }\end{array}$} & \multicolumn{3}{|c|}{$\begin{array}{c}\text { Максималь- } \\
\text { ное }\end{array}$} & \multicolumn{3}{|c|}{$\begin{array}{l}\text { Минималь- } \\
\text { ное }\end{array}$} & \multicolumn{3}{|c|}{ Амплитуда } \\
\hline & & + & 0 & - & - & 0 & + & + & 0 & - \\
\hline $\begin{array}{l}0 \text { группа : } \\
1 \text { группа : } \\
\text { Il группа : } \\
\text { III групла : }\end{array}$ & $\therefore \therefore:$ & $\begin{array}{r}6 \\
18 \\
26 \\
31\end{array}$ & $\begin{array}{l}1 \\
3 \\
7 \\
4\end{array}$ & $\begin{array}{l}1 \\
1 \\
4 \\
2\end{array}$ & $\begin{array}{r}6 \\
16 \\
7 \\
6\end{array}$ & $\begin{array}{l}2 \\
4 \\
8 \\
8\end{array}$ & $\begin{array}{r}0 \\
2 \\
22 \\
23\end{array}$ & $\begin{array}{r}8 \\
18 \\
19 \\
23\end{array}$ & $\begin{array}{l}0 \\
4 \\
7 \\
4\end{array}$ & $\begin{array}{r}0 \\
0 \\
11 \\
10\end{array}$ \\
\hline
\end{tabular}

числе случаев--уменьшение амплитуды кровяного давления.

Если сопоставить даннье функциональных испытаний при помощи нагрузки в 20 приседаний с приведенной пробой пульса и кровяного давления в зависимости от качания на качелях Хилова и вращения на кресле Барани, то последние пробы нам ничего нового в смысле характера реакций не дали, лишь все эти реакции были более рельефно выражены и в большем числе случаев. В амбулаториях и медпунктах, где нет подобных, специльно сконструированных качелей или кресла Барани, эодверженность морской болезни может быть выявлена методами функционального исследования сердечно-сосудистой системы:

Факторы, влияющие на предрасположениекм. б.

В этом отношении нас прежде всего интересует, насколько та или иная заболеваемость отражалась на организме в смысле усиления склонности к укачиваемости. Нами отмечались случаи склонности к м. б. у лиц плавсостава, перенесших тяжелые инфекционные заболевания, как тиф, малярия. Случаи невроза сердца с признаками ангионевроза почти исключительно встречаются во II и Ill группах. Мы наблюдали случай, когда моряк с большим плавателыны стажем, не подверженный в прошлом 
м. б., после бывшего 3 года тому назад заболевания малярией, дававшей в послсдующем обострения, начал страдать м. 6 . Отмечаемая в литературе склонность к м. б. у желудочнокишечных больных может быть объяснена тем, что зачастую и расстройство деятельности желудочно-кицецного тракта $y$ этих лнц нахопится в больной зависимости от неустойчнвости вегетативной нернной системы.

Фарфель находила влияние на стелень O. R. мышечной силы и роста: чем мышечная сила меньше, чем рост выше, тем степень O. R. более ныражена. $M$ ы произвели изучение соматики обследуемых и подобную занисимость не могли констатировать.

В заключение нужно отмстить, что по нашим данным средк пиц, не имеюшіх плавательного стажа, 8\% не подверғались заболеванию м. б. и $22 \%$-в очень слабой степени, $70^{\circ} \%$ укачивалйсь, нз них $35 \%$ в резкой степени. Практика показывает, что из числа первично резко укачиваюцихся тиц часть привыкает к морской канке, и в дальнейнем тяжело не болеет м. б. Некоторые из обследованных нами переходили на протяженин 3 месяцев плавательной практики из III во II, из Il в I группу м. б. Лицаже с выракенными гризнаками облдего невроза в первые годы занятий уходят из морских учебных заведений вслед ствие резких провнлений м. 6.

\section{Bmsodix:}

1. Ведуцая роль в патогенезс м. б. прннадлежит вегетативной нервной системе. Негетативный пенроз, антионевроз характерны для лиц, резко укачиваюпиися.

2. У лиц, поднерженных резким стеленям м. б., часто обнаруживаются проявления дистонии, лабильности сердечно-сосудистой снстемы, что н свог очередь занисит от подобного же состояния вегетатинной нервной системы.

Лабильность всгетатинной нервной системы, характердая для лиц, резко укачивацоцихся, находит свое отображение и в лабильности отолитового апнарата (Рувинский).

3. Чем больше фунжинональнғх проб́ сердечно-сосудистой системы указывает на лабильность ее у испытуемого и чем они жрче выражены, тем более достонерно пожно высказаться о предрасположении испьтуемого к м. 6.

4. Функциональные пробы сердечно-сосудистой системы разпражением вестибулярного апларата (канели Хилова, кресло Барани) вьзывают такие же реакции, как и после физическои нагрузи, но они более демонстративны.

5. На предрасположение қ м. б. могут влиять перенесенные тжслые инфекционные заболевания.

6. ІІри приеме в морские учебные заведения необходимо давать предночтене лигам с хорошими функционалыными пробами серденно-сосудистой и вегетативной нервной системн; лиц с шлохим сердечно-сосудистым аппаратом и плохой негетативной н. с. в смысле резкой лабильности их не следует прннимать.

В сомнительных случая надо устанавливать соответствуюциц контроль после тренировочного плавания. 
Tuтерапура. 1. Воячек, журн. „Ухо, горло, нос." 1927.-2. Јориневскй и Юориневская, Руководство по физической культуре и врачебному контролю. 1935- - 3. Л а н г, БМЭ, т. 30, стр. $254-\cdots 4$. Јукомский, Труды Центр, лабор. по нзученню проф. болезней на транспорте. 1928,- 5. Палеес. Морская болезнь. ЂМЭ, т. 18, стр, $732,-6$, Прайор, Морская гигиена. 1930,-7. Рувинский, Журн. ушн., нос., гор. болезней, т. 11, № 3, 1924.- 8. Саркизов-Серазини. Лещсбная физкультура.-9. Фарфель, физиолог. журнал. т. ХХ, вып. 2, ]936. - 10. Хилов, Вестни советск. отоларингологиж, № 4, ] ч33 и № 1, 1934.- 11, Bruns, "., Med. Kin. № $26,1914,-12$. Bruns O., Munch. med. Woch, 977, 1926.-13. Fisches J. Munch. med. Woch., № 30, 1913. -14. Fischer M., Fortschr. der Med. № 1, 1934.1.5. Flack, Brit. M. J. lan. 1931. - 16. Maitland, Brit, M. J. lan, 1931.

W1з тераневтиеского отделения (зав. А. А. Колачев) Шахтинской горбольницы имени В. В. Јенина (Гав. врач С. С. Драгицин)

\section{0 легочном раке у углекошов.}

\section{A. А. Колачев.}

Геория возникновения легочного рака вследствие хронически разлражений и восцдлений дыхательного тракта, в частности, на почве лневмокониоза, пользустся в данное время большим вниманием. Основанием для әтого взгляда послужил ряд патогистологических исследований, обнаружинших при хронических воспалительных процессах и пневмокониозе эпителиальную пролиферацио и метапластические изменения в слизистой бронхов и альнеоларном эाителии (Асканази, Шморль, Фрид, Давидовский), т. е. предкарциономатозное состояние.

Учитывая теоретическое и особенно социально-практическое значение раковой проблемы, исследователи обратились к вынснежию ролн пылевых профессий в этиологии легочного рака. Был опубликован ряд работ, в которлх авторы гытались установить зависимость обнаруженного ими легочного рака от вдыхания самых разнообразных газов и ныли на произведстве: окиси железа (Дрейфус), паров дихлорэтилена (Кикут), бензина у шоферов (Николов). Исследования проводились у рабочих сигарных фабрик (Зейфарт), у рабочих газовых, анилиновых, дегтярных и других производств. Но принодижые авторами слуцаи были едижичны и мало доказательны.

Брокбенк, проанализировавший все олубликованные случаи эрофессионального легочного рака, и Кеннавей, изучивший 18280 случаев смерти от рака легких и гортани в Англи за время с 1921 ло 1932 год, не нашли связи между легочным раком и лрофессией. На этом основания высказана была точка зрения, отрицающая возможность профессионального легочного рака.

Однако наличие профессионального легочного рака является неоспоримьм фактом у рабочих, длительно занятых на плохо оборудованных в санитарно-гилиеническом отношении германких фабриках в Людвигсгафене и Грисгейме, производящих хромать (Гросс, Телеки, Пфейль). То же отмечается у горнорабочих 
Шнееберга (Саксония) и рабочих Иохимсталя (Чехословакия), находящегося в 36 километрах от Шнееберга.

Действие хрома вполне объяснимо его химическими раздражаюцими свойствами, вызываюцими целый ряд изменений со стороны кожи и слизистых, и практическое значение этого вида легочного рака не выходит за пределы нескольких фабрик, вырабатывающих хроматы. С другой стороны, этиология шнеебергиохимстальского рака, оставаясь до последнего времени загадоцной, возбуждает общее внимание, в виду инкриминируемой раку связи с пневмакониозом.

Со времени опубликования Гартингом (1879) первых случаев легочного рака у пнееберлских горняков по $1912 \mathrm{l}$. в Шнееберге умерло от легочного рака 279 человек. Смертность от легочного рака по отношению ко всей смертности горняков составила за этот период $41 \%$ (Телски), а по мнению Ростоского и Заупе-даже $71 \%$. Естественно, что столь высокая смертность, повлекшая за собою постепенное бегство рабочих с этого рудника, насчитывавшего в 1879 году-700 рабочих, а в 1929 году 54 чсл., привлекла к себе всеобщее внимание, и вызвала ряд тщательных исследонанй, направленных на изучение цнеебергского легочного рака.

Работы Ростоского, Заупе, Шморля, исследовавших рабочих этого рудника в течение нескольких лет, и положили начало учению о карџиногенной роли пневмокониоза.

При рентгенообследовании (Заупе) 154 рудокопов-в том числе н прекратившнх работу--был обнаружен ряд лиц с явлениями пневмокониоза и одновременяо легочного рака и ряд лиц с чистым пневмокониозом, из которых у 4 человек в дальнейшем развился легоциый рак. Мысль о значении пневмокониоза, как этиологического фактора, казалось, была подтверждена гистологическими исслсдованиями Шморля, изучиншего 21 случай шнеебергского легочного рака и пришедшего к мысли о его возникновении из пневмокониотически измененных, индурированных, прорвавшихся лимфатических желез легких и из рубцов слизистой оболочки бронхов пневмокониотиков.

Обнаружение Леви (1929) легочного рака также и у добывающих урановую руду горнорабоџих Иохимсталя и появление затем работы Ция (1930), обследовавшего рентгенологически 332 рабочих этого рудника и констатировавшего пневмокониоз у 188 челонек (почти 60\%), значительно укрелили эту теорию. Распространению ее также способствовало появление сообцений, категорически отрицавиих какую-либо роль бисмула, никкеля, серебра, кобальта и мышьяка в возникновении легочного рака. Ни одного случая легочного рака у рабочих серебряных, бисмутовых и никкелевых рудников обнаружено не было. При обследовании рабочих других, кроме Шнееберга, кобальтовых рудников и заводов, вырабатываюџих стекло, в состав которого входит кобальтовый протоохид, легочный рак также не был обнаружен. Что касается мышьяка, добываемого, как и кобальт, на шнеебергском руднике, то тщательные поиски его в моче, 
нолосах и ногтях рудокогов, а также в воздухе шахт, в виде диэтиларсина, не уненчались успехом. При обследовании рабочих мышьяовых фабрик в Мильденгютте (Зауге) у 25\% рабочих были обнаружены легкие лневмокониотические изменения, но случаев легочного рака обнарукено ие было.

С точки зрения карциногенной роли пневмокониоза легко находили свое объяснение, во-первых, часто встрецающаяся пораженность раком обоих легких, во-вторых, медленное течение его (до 3,5 лет) у џнееберг-иохимстальских горняков, поскольку пневмокониотические изменения могут препятствовать пролиферации эгителия в склерозированной ткани.

Однако дальнейшее изучение нопроса привело к резкой кригике этой теории. Пирхан и Сикл (1932) не нашли пневмокониоза у иохимстальских рудоколов, несмотря на большое число случаев легочного рака, обнаружеиного на вскрытии (47\%). Ктому же последний встречался в нодавляющем тисле случаев у крепильщиков, поднергающихся действию пьли несравненно меньпе, чем забойщик, и наблюдался при различных степенях пневмокониоза без зависимости от интенсивности лоследнего.

Эти данные, в связи с появлением в печати сообщений о случаях легочного рака среди лиц, длительно работавших в радиевых лабораториях (Нейтцель), и о возможности развития легочного фиброза под влиянием радия (Бельт и Дейнеке), вновь привлекли общее внимание к радию и его эманации, как прғчине легочного рака у горняков шнееберл-иохимстальских рудников, ғода и воздух которых содержат огромное количество $\ni$ манации радия.

Мысль о возможном влиянии на развитие легоцного рака ингалированной содержащей радий пронзводственной пыли вскоре была опровергнута исследованиями, обнаружившими в рудничной пыли меньшее содеркание радия, чем в обычном граните.

Содержание радия в легких рудокопов, подвергавшихся в течение длйельного времеци действию пыли, содержацей радий, также оказалось столь ничтожным, что о влиянии его на легочную ткань не приходилось и думать (Бегунек, Мартланд).

Чельниц (1935), высказал взгляд, что на развитие шнеебергского рака влияет кремневая кислота, содержащаяся в пыли, вдыхаемой при работе.

Учитывая, что пневмокониоз углекопов в современном представлении рассматринается как антрако-силикоз, обязанный свонм происхождением длительному вдыханию угольной пыли с большиим иногда содержанием в нсй силиция, мы поставили перед. собою задану изучить вопрос, можно ли рассматривать антракосиликоз как предкарциноматозный процесс, как фактор, способствующий возникновению легочного paка.

Частота антрако-силикоза у углекопов достигает довольно значительньх цифр, колеблясь от $11 \%$ у горняков антрацитовьх копей Донбасса (Мошковский) до $23 \%$ у горняков Пенсильвании (Сайерс), а по данным английских авторов у старых горняков Уэльса доходие даже до 40,8\%. Чрезвычайно значительна также 
מысокая заболеваемость углекопов хроническими легочными стра даниями, которие-нацример у горняков Шахтинского антрацитового района-встречаются в 49.2\% (Массино), а в Бельгии даже в 95,5\% всех обследованных (Мартиі). По смертности от легочных заболеваний (исключая цневмонию и туберкулез) среди 72 обследованных профессий з Соединенных Штатах Америки первое место заниман углекоцы (Гофман).

Высокое содернание силиция в легоцной ткани углекогов, доходяাее по Куммину и IIладдену до 42,1\%, а по Ашнеру до $44,9 \%$ сухого остатка легких, казалось, обьясняло цастоту легонног рака у углекопов. Это подтверждалось патололо-анатомическими данными Липшица, согласно которым в Цвиккау (Саксонкя) пегочный рак встречался среди углекопов зикобы ж 5 раз чаще, чем у лищ, работавпих на открытон ноздухе.

В целях исследования нами были ироверены 3429 кірточек 3АГC на лиц, умерших в городе Шахты и в близлежапцих рудничнх поселках, в возрасте свыше 15 лет, за время с I/I 1934 г. по 1// 1937 [., причем за указдниый период времени на 153 слуная смертн от рака легочный рак был отмечен в 8 случаях.

Ни одного случая дегочного рака среди умерших горняков, чнсло которкх в городе и различны поселках колебалось от 20 до 25\% об́пего цисла умерших в зтом возрасте не иказалось.

Прн ироверке хранящихся в пенсиониом отделе Шахюинского Горсовпрофа 602 сиидетельств о смерти горняков, перешедших в инвалиды, до 1932 года ни одного случая смерти от легочного рака также об́наружено не было.

Необходимо отметить, что как в городе Шахты, так и в близлежаних рудниках горняки обслуживаютси кналифицированными, с большим практическим стажем врачами и густой сетью ренггено-кабинетов, так что принисать полученные результаты исключительно слабому диагносцированиюлегочного рака нет достатоцных оснований, тем более, пто последний обнаружен среди местного населения (не горняков) в больнем проценте случаев, यем в некоторых других городах нашего Союза.

У иитывая все же неполноленность даных ЗАГС, мы обратили особенное внимание на изучение частоты легочного рака у горняков, проходяних церез Шахтинсую ВТЭК и через терапевтическое отделенне местной городской больницы.

Все горняки, цроходившие ВТЭК, исклкочя травматиков, подвергались рентеноскспии легких, а подавляюшее больиинство лид с больним профстажен--стацонарному, комплексному, вклкцая рентгенографию, обследованию. Несмотря на столь тщательное обследование, ни у одного человека из 3500 горняков, прошедших ВТЭК за 1932-1936 г леконоло рака обнаружить не удалось.

Что касается данных стационара, то на 16652 больных, из которых 4310 были горники, прошедших через терапевтическое отделение горбольницы за 1929-1936 гг, легочный рак наблюдался в 7 случаях, из которых только в одном случае у горняка. 


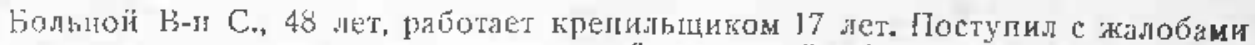
па кашели, периодически-с кровянистой мокротой, боли в иравой толовнне ррудной киетки и прогрессируюцее исхудание в теление последни пяти месылев. Рептген: ателектаз верхней доли правого легкого и начальные явлсния алтракоза. Подозрснис на рак. На секіии карцинома верхней доли лравого эегкого с одиночағми метастазами в средостении. Расширение лравого верхнего бронха. Умерснио выфаженный фиброз и сплопияя уголғная пигментация ббонх легких, бронхопулиональных и бифуркапиогных желез. Последние вилерплязироганы, мягк, нс слаянц с окружаюшими тканями.

Гистологически: мслкоклеточаы̆ рак и зыраженный фиброз со зазиительным скопнением угольных частил в легочной ткани обоих легких.

Столь низкая заболеваемость углекопов легоцным раком отвечает, по нашим наблыденим, вообще низкой заболеваемости углекопов раковой болезньк. По даниым тералевтического отделения Шахтинской больницы, где за 8 лет прошло 6652 больных, рак пилденарельпого тракта наблюдался у 91 человека, из иих у 19 горняков $\left(0,44^{\circ} / 0\right)$ и 72 у прочих больных $(0,58 \%)$. 1з 9 случаев кожного рака, зарегистрированных Шахтинским нендиспансером в $1936-1937$ гл, лишь один случай относился к горняку.

'О, что тегочный рак встречается среди горняков не чаще, цем у лиц других профессий, паходит свое подтверждение и в патололо-анатонических данных южно-африканских авторов, которье обнаружили легочный рак среди 1083 умерших рудокопон с силикозом н 4 стучаях, у 1109 рудокопов без силикозав 6 случанх и среди 1023 лиц, никогпа не работанших в шахтах - в 6 случаях.

Еднничные случая легочного рака, комбинированного с rневнокониозом, опубликованы Гюйоном, Линчем и Смитом (азбестоз), Дубле, Фиано и Джезо (силикоз) и Пенкоост и Пендергрэсс (антрако-силикоз). Если учесть, что в Америке по Ланца нмеется 500000 лй, подвергаюцихся действио ндыхаемого ими силиция, то на основании этих случаев нельзя говоритьо какой.либо связи легонноло рака с пневмокониозом.

Выводы: 1) Легочный рақ у горняков llахтинских антрацитоних рудников нстречается весьма редко.

2) ППневмокониоз горняков-углекопов (антрако-силикоз) не служит предрасполагающим моментом к возникновению легочного рака.

3) Заболеваемость углеконов раковой болезнью значительно ниже, чен у прочего населения. 


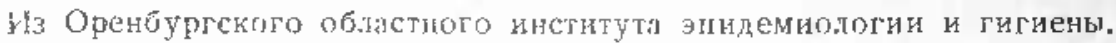

\section{Тнфоподобные заболевания с палочной Гертнера в крови.}

\section{3. Е. Отвиновская и Б. В. Успенский.}

Роль Гертнеровской палочки (по международной классификации 1933 г. S. enteritidis) в этиологии гғиевых отравлений давно известиа. По зтому вопросу имеется больиая иностранная я русская литература. Иоффе в свосй работе "О группе b. enteritidis Gärtner" приводит данные Сепеджа и Уайта, согласно которым „среди отравлений алиментарного характера $1 / 4$ всех случаен приходится на долю Гертнеровской палоцки". Хорст Габ̆с сообцает, что палочка Гертнера в Гейдельберге в 1932 1933 гг. была вылелена в 13\% случаев пицевых отравлений. Такой процент $(10-15 \%)$ принодится в этой же статье и по материалам Кауфмана.

В клинической картице заболеваний, вызванных палочкой Гертнера, преобладают явления гастроэнтерита и общего отранления организма. Обыхным обьектом для выделения палочки Гертнера служат остатки иищевых продуктов, рвотные и каловые массы пострадавших. Нахождение ири массовых отравлениях Гертнеровской палочки в грони больных описывается редко (Пшеничников, Райхер).

Больцинство авторов сцитает, что роль Гертнеровских палочек в клинике нестных и обцих заболевапий нгевлика. Беме и Ритгер, а также Дэн, сообцают о случаях холецистита, Нейман-о случаях цистита, Стюарт и Крикориан, Олиций, Пеш, Габс и др. опкывают случаи менингита.

Особый диагностический интерес иредставляют тифогодобные заболевапия, при которых н крови и выделениях человека находят различных представителен паратифозной группы, считавเиихя ранее мало или даже совсем непатогеними для человека. Примером может служить всиынға паратифа $\mathrm{N}$ в $1921-$ 1922 гг. После описания этой всыынки, связаной по Нвашенцеву с возвратным тифом, имеются сообіцения об отдельных случая подобных заболеваний (Диугач о 4 случаях в Ростове н/Дону, Грекон об 1 случае в Ташкенте).

Поэтому мы сиитаен не линним сообиить о трех случаях заболеваний с дианнозом "брғшной тиф", при которых в крови была найдена палочка из группы Г'ертнера.

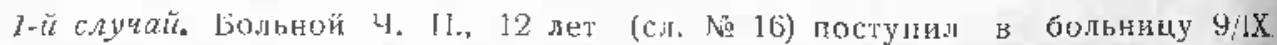

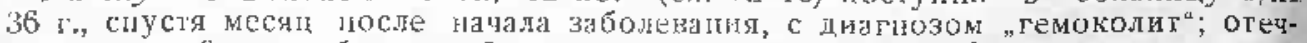
ность правой ноги, боли и области паха; стул жидкий 5-6 раз в сутки, головиые боли. Температура $39,3^{\circ}$. Дома в натале заболевания был кровавый понос, потом временное улучшение, после которого вновь повысилась температура, наступили явления тромбофлебита. Легкие все время $\mathrm{N}$, ссрдце $\mathrm{N}$, желтуги не было. Течение болезнн волнобразиое: утихали боли, уяеньшался отек, синжа- 
лась темыература, затем повая атака: повыщеиие температуры, боли, увеличение отека. Процесс охеатил поогередно обе ноги. Взее время понос от в сутки. Больной вынисан после 66 дисй пахожаденя в больнице; иоги в норме, њонос прекратился, общее состояние знахительно улучшнлось, но температура оставалась жабияьной, тпк пуго о полиом выздоровлении говорить нельзя.

Исследование крови: на 4642 день болезни лейкоцитов 4840 , ға $63-\ddot{4}-5600$.

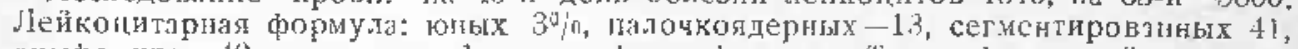
энмфоцигов 40, моноцитов 1, эозинофилов 1, кіеток Үюрка ], г. е. нейтро-моноэрзилопеня с исбольия сдеигом пейлрофилов. Малярийных паразитов не наидепо. Из посева крови на 46-й день болезни выделена палочка Гертнера; на1 65-й-бактерий в крови не обпаружено.

Реакция Видаля на 46-й день болезни положитеныа с палочками тифа 1:40). паратиф̆а В 1:110, с диэентернйıыми Шига 1:100, паратифа А и дизентерийными пллочкаи флекснера отрипательн; с палочками Гертнера не была постанден. Ћовторная р. Видаля на 63-й день болезни-положительна с палочками бртош ного тифа $]: 800$, паратифа В $I: 400$, Гертнера $1: 2000$, с дизелтерийными палочками Џига и Флексіера 1:400, ларагифа А отрицательа. На 75 -й дена болезни льз мочи выделена чглочка Гертиера, па 89-й посев отритателен. На 79-й лень болезни в моте белка "033\%, в осалке жного лейкоцитов, на 83-й и 88-й ден болезни-моча N. На 64 -й и 75 -й дешь из кала выделена слабо агглютинируюпцаяся палоцка Флекснера.

Заключение лецанего врача: „если бы из крови и мочи не быля выделсна палочка Гертнера, клиническое наблюдение впонне мирилось бы с диағнозом:

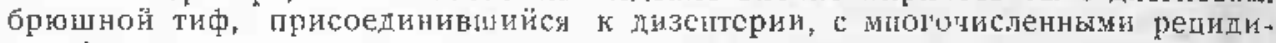
вами*.

2-й cлунай. Боцьой В-в Ал-др, 11 лет (№ 32). Поступил в больниту $28 / \mathrm{X} 36 \mathrm{r}$. на 14 -й день болезня с диагнозом „катаральня пневмония “. Болезнь пачалась с головной боли и кашля. Жалобы на бояь во всем теле и резко выражешую слбость. Бросляся в глаза бледио-серый цвет тожи; желтушности

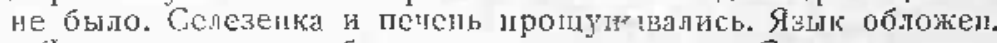

Явления в легких бистро пришли к порме. Стул ғсе время нормален. Пульс отстает от температуры (100 при $\left.39^{\circ}\right)$. Тоны сердца гыухи. На 17 -й день бозезии единицые розеолы па животе. Никаких осложнений пе наблюдалось. Тсмпера . гурная кривая тинитна дия брюшного тифа.

Ііри посеве крови на 15 -й ден болезии выделена палочка Гертіера. На 31-й ден ее обнаружить в крови не удалось.

Реакция Видаля на 15-й и 31-й день почти с оямнаковыми результатамн: положительна с палочками брюшного тифа-1:4!), ларатифа $A-1: 10$ ), паратифа В.. 1:109, с палогкам Іертнера больпе 1:80 . Колитес, во тейкоцитов на 15-й денб, 33!), па 31-й день-5500. Лейкоцитарпая формуліа на 15-й день: зоных $30 / 0$, плаликолдериых 16 . сегментир ваных 48 , лимфоцитов 28, моноцитов 5 , т. е. псйкопеия со сдвигом нейтрофилов. При посеве иопи на 31 -й день ничего иатологического не обнаружено.

З-й случай. Больная К-э, 8 лет (№ 33). Живет на одном дворе с больным В.м (2-й случай) и заболела почти однонрененно с ним $15 / 16 / \mathrm{X} 36$ г. В больницу поступила на 10-12-й день болезни в дороцем состоянии, несмотря на высокую температуру. Я્રык слегка обложен. Селезснка плотная, выступает на 2 пальн, печепь-на 1 палец. Легкие и сердие N. Стул нормальный. Все время дорошес самочуяствне. На 18-і день болезни поднялась температура, появился гаротит, рассосавшиёся за $3-\cdots 4$ дня, Іроб̆ыла в больнице 24 дня.

Цағиые апализов: на 14-йдень болезпи из крови выделена палотка Гертнера, на 30 й лень- посев кровг отрицательый. Реакщия Видаля на 14-й день положительна с палочками тифа-1:200, паратифом B-1:200, Гертнера-1:800, паратифа А- -о рипательна. На 30-й дснь реакция Внцаля с пзлонами тифа-1:400, ларатифа B- 1:200, Гертыера 1:400, шарттифа А-отринательна. Количество лей-

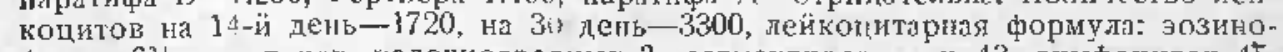
филов $6^{3}$; , юных нет, палочкоялерных 3 , сегментировннных 43 , лимфоцитов 45 , моноцитов 3 , т. е. пейтро-монопения без сдвигd нсйтрофилов. На 21 -й денк болезни при поссве мочи Гертұеровских палоџек не обнаружено.

По заключению лечащего врауа оба эти слудая клинически протекаяи как брюшной ғиф: у В·а-как случай средней тяжести без осложнений, у К-нойкак легкий случай. 
В отнопени әлидемиологи наших случаев мы выяснили крайне мало. В первом случае больной был досталлен в детскук? больнишу из района, где наблюданись дизеитерийые заболевания (у этоло больноло из кала была выделена палочка флекснера-см. вL $111 \mathrm{C})$.

Двя других заболсвания были у дстсй сезонных рабочих, жипущих в обшежитиях $6-10$ мес. Одновременность заболенания пьух больных нзз этих обцежигий заставил предположить, не било ли тая вспышин заболеваний цишеного характера; однако тпательғын опрос населения общежитий этого не подтвердил. Mы не могли отметить также у живупих в этих общежитиях контакта с животньни.

В этих же общенитиях за нремя с иннаря по ноябрь наблюдалось 3 случан брлотного тифа. У одного из болевших бргшным тифом, только-что выписавшегося из больницы, поставленназ нами р. Бидаля была шоложительной с далочкой тифа и отрицательной с Гертиеровской. Повидимому, и Іертнеровская и тифозная инфекции супествовяли в этих общежитиях самостоятельно, и напи случаи следует сцитать спорадическими. Непосредстненного источника инфекции установить пе удалось.

Характериспика выделенных кулыпур. Кровь, взитал из локтевой вены, частьо засевалась в желтный бульон, частьо выливалась в стерильнуо гробирку и шла лля юостановки р, агглютинации. I Іосле отсаснынания сыворотки, сгусток такле заливался жельным бульоном и ставился в термостат. 1Ј посева крови и сгустка перез суткн (а в случае отрицательноло результата вторично через 5-7 дней) делался внсен на косой ауар. В первом из отысанных выле слутаев культура была выделсна из посева пелой крови, во второн и трстьем-только из посева сгустков; параллельнй засев пелой крови и суустка может дать, следовательно, больчий процент положительных результатов.

Мона и кал от всех больных зассвались неносредственно на среду Элдо и в желчннй бульон.

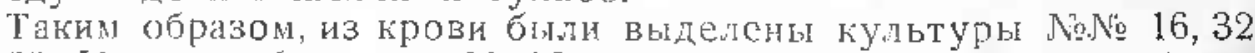
и 33. Из мочи больного № 16-культура № 16м. Из қала больного No 16 - культура № I6r, оказанцшяся слабо агюлютинируюшейсн палоцио̆ Флекснера (iосле 2-10 пассала через тлюкозу).

Учитьвая возможность смепияной ннфскиит и нозмокность ноявлендя в крови палочки Гертнсра, как сопутствующего

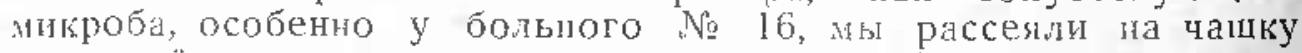

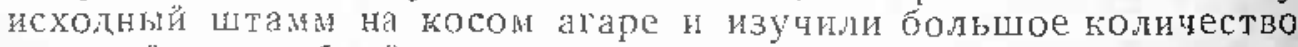
колоний в пробной агглютипақи, птачсь найти колонию палочек тифа или паратифа $A, B, 11$ коланий изучено биохимически н 20 посредством микроаглютинақия. Несмотря на тщательные поиски, нам не удалось обнаружить жолопий цругого тила; неизменно мы получали одни и те же результаты; все колоник имели вал; давйли образование газа в тлюкозе и маниите, аггльтинацию с сывороткой тифа, паратифа А, B, суипестифер, Бреслау ие выше, цем $1: 100$, и только с Гертнеровской сывороткой 
также постоянно мы получали агглютинацию в ботее высоких разиеденияіх.

Морфологическая би бионмическая характеристика еыделенных птаммов видна нз следуоцей таблицы:

Tаблита биохининекой харакперистики.

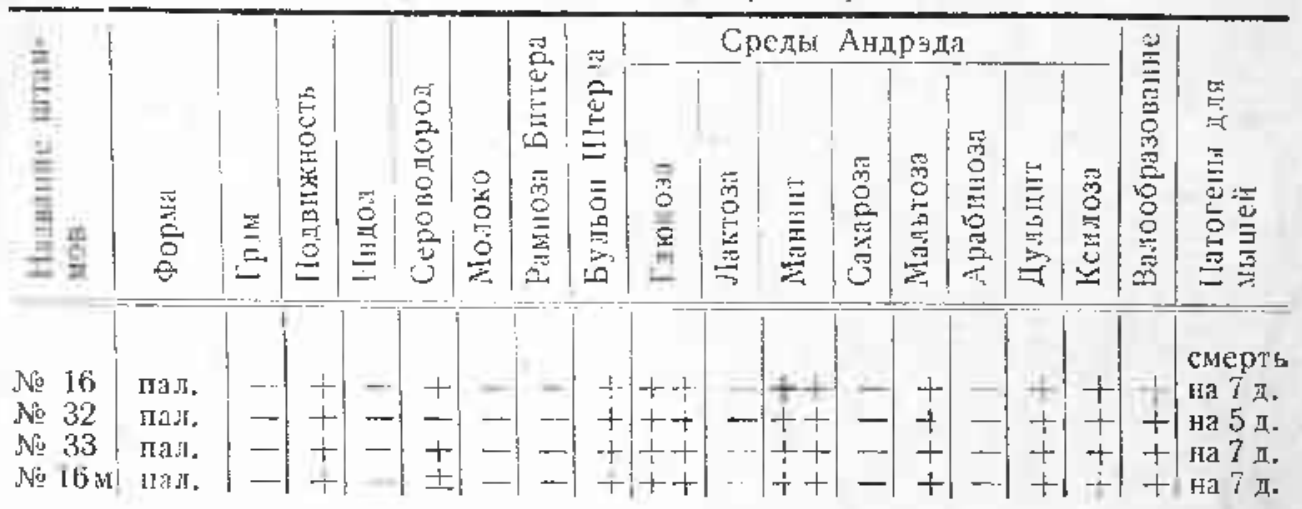

Методика заражения: мыши слизывали по ] пепше агаровой культуры. После смерти из всех органов, из крови сердца и нз головного и спинног мозга выделены культуры, идентиныые с культураи, послужившими дія заражения.

Для серологической характеристики выделенных штаммов одиовременно и при одинаковых условиях ставилась прямая р. агтлотипации и р. Кастеллани.

Tаб̆лиt, серологической характеристики.

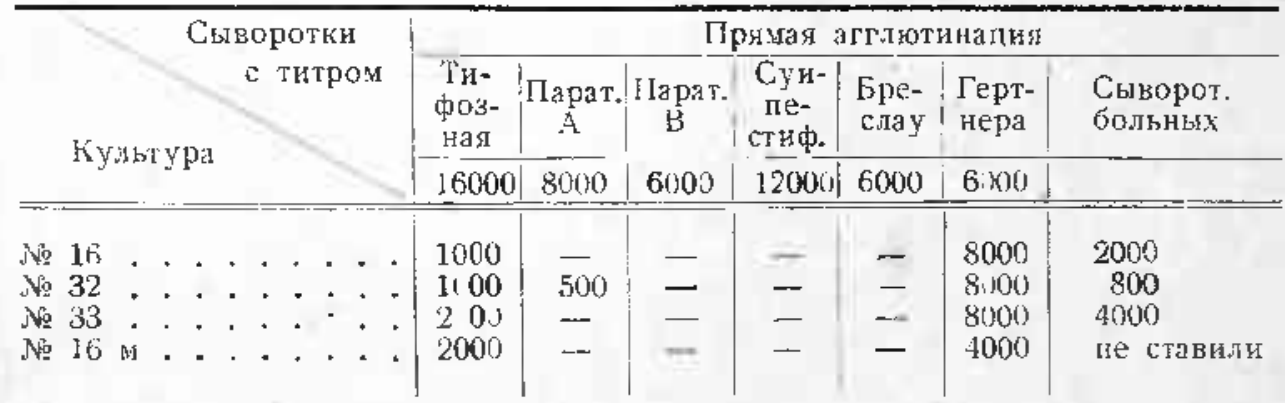

P. Кастеллани производилась путем насыщения сывороток тифозной, паратифозной А и В, Бреслау, суипестифер и Гертнеровской штамыами №№ $16,32,33$ и 16 м и цоследующей постановкой р. агглютинации с соответствуощими музейными штаммами. Результат во всех слудаях был одинаков: наши итаммы не извлекали агглютининов из всех упомянутых сывороток, кроме Гертнеровской. Из последней же они полностью извлекали все агілютинныь.

Вакцинами из культур № $16,32,33$ иммунизировани 3 кроликов. Через 10 дней после последнего введения вакцины, сыворотки от всех кроликов в равной степени (1:2000-1:4000) аггльтинировали культуры № 16, 32, 33 и музейный Гертнеровский штанм. 


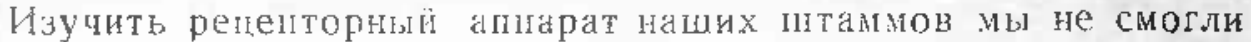
лвнду отсугствия тиноных сывороток и были вынуждены ограничнться приведеными исследованиями. Нельзя не пожалеть, что эти сыворо'ки явыяются еiце малодоступными, и поэтому мы, как и рид дру!их авторов, не имели возможности идентифицировать выделеннде штамы по международной классификации Salmonella, принитой в 1933 r.

В провсдениц нами методах исследонания наши штаммы серологичеки, биохияически и биологически вели себя, как типичные h. enteritidis Gärtner. На основании же биохимических свойств можно думать, что все 4 niтамма относsтся к типу Gärtner-Kiel (ғо биохимической классификации Кауфмана и Митсуи), отнесенному по мсждународной классификации к варианту Dublin.

Bы $802 \%$. 1. Все паблодавшиеся намн случа тифоподобного заболевания вцзваны цалочкой І'ертнер-Киль.

2. Заболевания, вызываемғе палочкой Гертлер-киль, могут протекать клинически как брњшной тифф.

3. Все тифоподобные заболевания қолжны подергаться бактериологическому исследонанию для выяснения роли Гертнеровской палочки в этиологии этих заболеваний.

4. Гертнеровская иалоцка может вызывать не только вспышки пиненых токсикоинфеғций, но и давать отдельные спорадические тифоподобные заболевания.

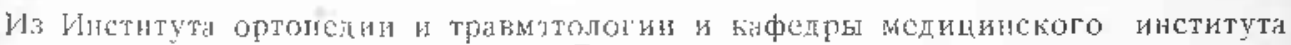
в Taшкенте.

0 ранних сиялтомах заболевания позвоночника туберкулезом.

\section{Проф. С. B. Кофман.}

Туберкулез эз костях гнездится гредпочтительно на местах нанбольсго скопления губчатой (сионгиознои) ткан, именно в позвонғах, главным образом-в их телах. Около $45 \%$ случаев заболевания костным туберкулезом палают на позвоночняк.

В результате заболевания позвоночник деформируется, юолуцается общеизвестный gibbus; по наним наблюдениям в $20 \%$ случаев наблодается слондилит без горба: последний еще не развился или вообще процесс протекает без образования горба. В этих случаях симптомы, как объективные, так в особенности суб́ъективные, весьма разноречивы и разнозначущи; они ставят исследующего нрача втуиик. Симитомы говорят то за интеркостальную нейралгию, то за язву 12-перстюй кишки, за печеночную или почечную колику, аппендицит, пиелит, ишиас и т. п. Онн очень часто приводят к сонершенно ненужной, часто вредной терации, как медикаментозной, так и хирургической.

В теңение последних 20 лет мы запимались изучением зтого явления и пришли к следуюшим выводам. 
Туберкулезный процесс протекает медленно, долгое время остается латентным (по нашим и других авторов наблюдениямне меньше года, а то и полутора). Смотря по локализации в самих позвонках-то на передней, то на зацней поверхности, то внутри тела их...-результаты разруиительного действия туб. процесса выявляюося различно. В одних случаях процесс влияетна спинноё мозг и его оболочки, наруцая отправления висцеральншх органов грудной и чаще брюшной полости; в других случаях вызывает рорматицю口 изменения, ввнде спадения позвонка и выталкижания его кзади. Несомненно, что в единичных случаях бывает и быстрое появление горба; такие факты в литературе описаны. Но иногда, когда спондилит иротешает медленно, он несомненно находит сианала огражение во внешности больного.

Предтечей горба являются признаки недостаточности позвоночник, ело неспособности носить вышележащие части тела и придавать им желательное положение. Этот момент врач должен уметь подметить и расшифровать. Осмотр, наблюдение, тщательнос изучение формы тела, все то, что так умель культинировати старые врачи и от чего мы пाочти совсем отошли вследствие поянлсния иных способов исследования, может нам дать многое. Надо только всегда перел своим мысленным взглядом инеть формы тела нормального человека и хорошо знаты все пвижения его при вылолнении тех или других функций.

Пользуясь осмотрон как методом исследования, надо всегда сүавить совершенно раздетого больного перед истоцником света (окном) так, цтобл он бн,л освещен равномерно; наб́людатель при этом становится мекду нсточником света и исследуемым.

У здорового чсловека ири осмотре его сиины можно наблюдать идушую вдоль всего позвоночника борозду-sulcus spinalis, она тянется от затылка до крестца; смотря по степеки развития мускулатуры исследуемого борозда эта то более глубокая, то болсе мелкая; в глубине борозды ясно выступают остистые отростки. При напряжении мускулатуры спины так, чтобы лопатки сошлись, борозда эта углубляется, при әтом мускулатура резко выступает и на ощупь становится твердой.

Если исследуемый-носитель какого-либо заболевания позвонкон, у него эта борозда псясно выражена на всем протяжении, она часто бывает прерванной. Ғсли заставить его напрячь, выпрямить свой позвоночник, то при заболевания позвонка зто вьпрямление пе удается по всему позвоночнику, какая-нибудь часть его остается пеподвижыой; мускулатура вокруг этой части окажется сокрашенной, но без результата. IIри туберкулезном поражении такой участок также остается нелоднижным, но мускулатура вокруг него оказы в ае тся мя кощ, а не напряженной. В данном случае мы наблюдаем парез участка спинной мускулатуры-она аягка как тесто, она не сократилась на зтон месте, она не в состоянии ни двигать позвоночник, ни переносить тякесть тела. Это уплоцение мы называем сим птомом ладони; он очень рано свидетельствует о поражснии позвоночника туберкулезом: рань- 
ше, чем это может ныявить даже рентсловский снимок, который вообпе в расілзнавании туб. поражения позвонков часто несостоятелен. Мы инеен внашей казунстике случай, в котором нашими сотрудникали растознан слондилит, тогда как рентге. новский снимок пи прижизпсно, пи на препарате ничего патоногнческого со стороны позвоночника не обнаружил, а стало зто очевидным только при сагитальном распиле позвоночника. Налице өписанного ушлопения нас никогда не обианывало относительно состоння позвоноцника. Если это уплоцение захватывает болышуг часть позвоночника, или мы нообце не наблюдаем наличия борозды, ны смсло утверждаем, что поражен весь позвоночник, в чем мы в однон случае тотального поражения ныели возможиость убедитьсл. Часто уплоненис имеет вил ромба или үебольного овала. Если такого больного исследовать в лежачем положения, то уплопенис мы также наблюдаем, но мускулатура вокруг него ны так мягка и несколько контрагирована. Это модно обълснит тем, что она только парэтична, а не паралцзована, и в состолния еце проявлять свои сократительные способност. этот факт не был замецен проф. Fraserom из Эдинбурга, который тикже подметил появление описанного намн уллощения (fiattening) прн спондилите.

Для врачей-терапентон знакомство с этим ранним симптомом особенно важно потому, что по наним паблюдениям и по литературным данным spondylitis tub. весьма часто вылвляется после констатиронания поражени респираторнгі органон, в особенности плевры.

Mы топагаем, что осведомлепность об описанном симптоме номожет выяснить гораздо раньше эричину жалоб на межреберную невралию и другие болезнепиые явлиия и вместе с зтим даст надекду на успешное действие терапии. 
Из госпнтаьой хирург. клииики Омского мединстиута инен М. К. Кллииина (директор проф. А. А. Ожерельев).

\section{Нзолированный перелом ладьевидной кости запястья}

\section{В. В. Шкяяев.}

Переломы составляют одну из основных глав транматологин: на их долю падает от 15 до $20 \%$ нсех попреждений целонеческого тела. Из этого цисла более $50 \%$ составлялот перелонд нерхней конечности, лричем частота локализации их на этом участке распределяетс примерно слелуюшцм образом: на ключицу падает от 30 до $32 \%$; на плечо $15 \%$; на предплечье 34 $35 \%$; на запястье $3-6^{*} / 0$ и, наконеш, на кисть $15-16^{\circ} \%$. Таким образом переломы костей запястья встрецаются не так уж рсдио.

Небезинтересно отнетиты қстати, что авторами некоторых работ по этому вопросу знльются не клиницисты, а рентгенологи (Дьяненко, Заркевич и др.), что объясняется повидимому тем, что наибольиее количество материдла копцентрируется у по следних.

Нз костей запстья в громадном болышннсне случаев травмнруетсы иервый ряд этого отдела, как наиболее фиксированнын; наоборот, несколько больпая подвижность отденыных костей второго ряда ослабляет действие травмы.

Чaие всего страдает ладьевидная кость. Так, на материале Гамбургской портовой больницы за время с 1921 по 1931 г. жа 217 зарегистрированных повреждений запястья перелом ладьевидной кости отыечен в 103 случаях (48\%). Данные Эдена, основаныне на материале австро-германского архива страховых обиеств, з этом отношении епце более показательны: из 234 переломон костей запястьи 147 случаев, или 63\%, падает на ладьевидные кости.

Второе место по частоте занималот переломы трехгранной костн-29\%. Остальные кости запястья травматируются значительно реже.

Изолированны иерелом os naviculare њиервые был устанонлен на вскрытии Летенэром в 1839 г. Естественно, что с тех Iор в изучснии переломов ладьевидной кости проделана болыпая работа: этот вид переломов описан многими авторами, установлена их клиническая картина, разработана анатомия њ физиология как здоровой, так и поврежденной кости. Ђольшое количество экспериментальных изысканий и клинических наблюдений, қак русских, так и иностранных авторов, не исчерпало однако со всей полнотой этоло вопроса. Остаетсы много неисного не только в части лечения и патогенеза, но и в ранней диагностике этих переломов.

Совершенно естественно поэтому, ито современная литература не перестает уделять зтому вопросу должное и вполне заслуженное внимане.

Матерналом для настоящей работы послужили восемь случаев 
нзолнрованного иерелома́ лацьевидной кости запястья, пропедших через хирургиеский кабинет центрлльной поликлиники Омской ж. д. с начала 1935 по июль 1936 г. Все случаи относятся ж. людям физитеского труда-рабочим железнодорожного транспорта; из них мужцин от 20 до 40 л.-7; женгина-1 в возрасте 58 лет. Характер повреждения: иоперечных переломов через середину кости-4; отрыв периферического копца-1; оскольчатых косых исреломов перифрерического фралмента-1; оскольчатых лереломов с лученой стороны в средней третн-1; переломов со знацитльно выраженной дерорыацисй и смеценисм-1. Из этого числа 6 переломов свежих и 2 старнд, давностью примерно в 1 год. Праная рука повреждалась 6 раз, левая-2. В 6 случаях переломы не сопровождались почти никақим сыешением отломков.

В вопросе патогенеза nереломов лальев. пости мы не имеем и по настоялсе время единс'на миений. Вольф об̆ясняет механизм повреждения псредячсй удара с ладони чериз кости второго ряда залястья с одновременты противоударом со стороны луча. При отвсдении кисти этому перелому способствует ущсмление ладье видной кости нежду головчатой костыо и головиой луча. Магнус н Росток полагант, что нерелом os naviculare rроисходит не только под влияиисн тяжельх однократных травм (напр. падение на руку), но и в результатс незначительных повторных воздействий, жоторые нередко едва ли могут быть названы травмами. Волконич отондестияет механизм перелома лапьсвидной кости с механизом классического перелома луча - падение на согнутую в лучезапистно суставс и радиально отведеннук кисть.

Костручио, ириходы к тем ке выводам, считает однако нелременным услонием цля получения порспома определенные взаимотношения между кистьо и лредллечьем: при действии силь со сгороны предлиечья угол при разгибании должен равняться 90", ш кость должна находиься в радиально огведении. Жолондзь, образно сравнивая ладьевидную и полулунную кости с „буфером", заложенным между плечом в целом и дистальным рядом костей залястья- „раскосаяк", приходит к заключенио, что согласно законам механики "буферы" (в данном случае ладьевидная кость) должны ломатьсл чаще и скорее нежели "раскосы " между которыми эти "буферы" залокены. Iloэтону, 1ю ело миению, при указанном мсханизме лацьенидная қость ломается чаце дияфиза туча.

Наконеп, в последнее вреня Заркевич, на основании изучсния жеханических условнй перелома на труіах, приходит к выводу, что „живая кость дает перелом не только от пасилия, но перелом в ней подлотовляетси патологическим процессом“.

Механизм повреждения в нашем материале представляет доволын пеструіо картину: в ляти случаях перелом наступил при гадении на вытянутую руку в положении тыльного сгибания кисти; в двух-кисть, наоборот, находилась в ладонном сгибании. Наконел, в одном случае причиной перелома послужила непосредственная травма лучезалястного сустава (удар тылом кисти о рельсу при lіадении), 
Возникает естественный вопрос о более точной дифференцнации механизма иереломов ладьевидной кости, так как, несмотря жа наличие вышеприведенных теорий, остастся совершенно невыясненным вопрос, почсму в одних случаях ломается луч, а в других ладњсвидыая кость, тогда как часто и в том и другом случаях в анамезе указывается на аналогичную, ло своему характеру, травму. Надо думать, что необходим целый ряд дополнительных факторов и в механизме травмы и в самой структуре ладьевидной кости, которые в своей совокупности могли бы обусловить перелом этой кости.

Ранняя дифференциальная диагностика изолированных перел10мов ладьевидной кости несомненно трудна яе только клинически, но и ири рентгенографик. Нелравильное положение кисти при рентгснографии может нослужить притиной просмотра перелома, так как щель перелома три облдном тыльно-ладонном сниме в ноложении разгибания не всегда видна.

ГІодобный случай имел место и в нашем материале.

Больной В-ков, 19 лет, токарь қотельиого цехл, 19 Vil 36 г., возврадаясь ветером с работы, улал и ударился тылом нрввой кисти о рельсу. Объективнопезнцительна припухлость в путезапястіом суставе и болезненность при движении. На рентеногріние костные нзиенелия не обнаружены (обычный тыльнолалоннй снимок в поножении разгйаня кисти). Чсрез 5 дней больной вылисан на работу. 26/Vll, т. е. через день после погашеиия б/листка В-ков внові, обратияся в поликлинику с жалобами на сильные боли, ограничение подвижности и припухлость в лугезапастном суставе. ІЈовторный снимок кисти, ни уже согнутой в кулак: тадьевиднан кость разломана на 2 равныс масти без смецения фрагментов Т'ыльная шинка по Розеру на 3 педели с последующим физиотерлдевтическим іечением. На контрольном реитгене, хорошая костная мозоль. Жалоб не предьявля.

Во избежание подобного рода ошибок Шнек советует при фасном снимке кисть слегка согнуть в кулак, благодаря чему она устанавливается в положение легкого тыльного сгибания и ульнарного отведения. Тогда ладьевидная кость и щель между отломками становится видной на всем своем протяжении, Для бокового сника он считает целесообразным положение полутронадии, так как при зтом ладьевидная кость видна на пластинке но всо длнну и не закрывается соседними костями.

Допущсние ошибок в диагностике связано повидимому не только с техническни погрешностями ренгенография. Шнек считает, что при переломе ладьевидной кости цель между отломками не всегда видна сразу, а констатируется иногда через 2-3 и даже 4 недели после травмы (привожу по Заркевичу).

Наконец, нельзя обойти молчнием с точки зрения ошибок в диагностике и такие случаи, когда и объективные данные и субъектинне ощущения самоло больного (боль, наруиение функций и гр.) выражены настолько слабо, что вообще нет никаких оснований говорить о переломе ладьевидной кости.

Для илиюстрации иривожу наш случай.

Больной Т-лин, 33 пет, слесарь. Обратился в хирургический као̆ияст полнклиники зо поводу инородното тела в мягких тканях тыла левой кисти. Других жалоб нет. Рентгегограма показала, помимо илородного тела, старый полереqный перелом ладьевидной костн. Отломки не срослись (псевдопртроз). Ли- 


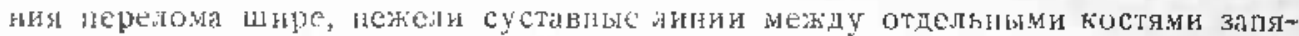

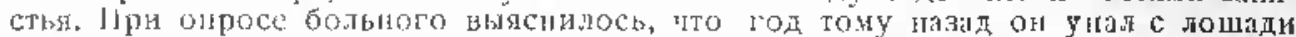

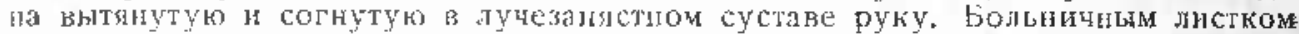

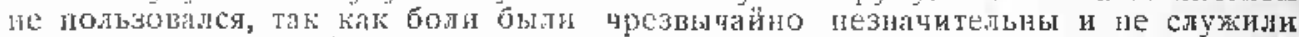
ломехой в работе (в то вреня больной работал вестовым). О су ществованик лерелома даже пе предполагы. Рукой вылыеет прекрасно.

Mbсль о возможности свежего перелома ладыенидной қости базируется с тони зрения клиники гланным образом на наличии достаточно резкой болезнениости ири пальпании сбласти „анатонической табаксрки" й ладьевидной кости, онределяемой как с тьльпой, үак и с волярной стороны (в нанем материале зтот симлтон всегда инел несто), на прниухлосүи, то сдна заметной, то сильно выражецной, и па ограничелии фупкция лучезапястного сустав. Кровоподтек и костнан крепиталия сопровождает перелом далеко це нсегда́. Крениталия может паблылатьсы, но может и не бнть, что стонт в зависниости как от характера самого нерелома, так и от наличия кровокзлияния. 13 напғен материяле крепитация не отмецалась ни разу.

В застарелых случаях перелома тальевидной кости все вынеприведенные симтомы могут быть выражены н различной степени, они могут то ослабевать, то ниовь усиливаться, особенно После форсированных движений.

Самым серьезным и улорным явлением при старых переломах явалетс парушение подвижности в кистевом сустане в зависимости от образования loxarthrosis interscaphoidea, arthritis deformans и анкилоза. $K$ этону надо қобаннть еще очень частое наступление мншецной атрофии н, как следствие этого, ослабление мышемной силы кисти, внккугее за собой подчас инваi) идность.

\section{Іривоку паш случай.}

Колхозник А-нюк, 28 г.; обратилез в поликлиния в начале 1936 г. но поводу болей, резколо оспабения мышечной силы (при измерения силы сжатия днщанометром слев́ $45 \mathrm{kr}$, справа $16 \mathrm{~m}$ ) и орранненгя подвижности в правом лудезапстиом суставе.

Iрриерно тод тому назад в пьяном виде А-нок упат иа ходу с крестьянсих дрожек па тыльо солуутую в кистевом сустве иравую руку. Через нескалько

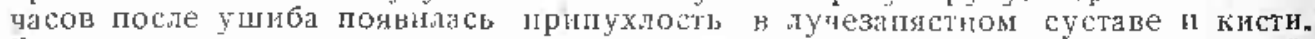

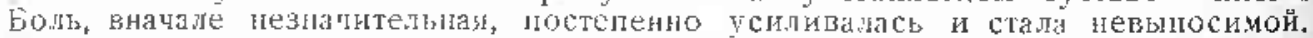

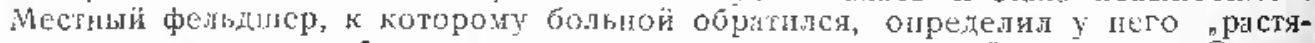
жение связок сустй и рекомендовал пелаты сотреваний компресс. Спустя $2-3$ недети припухлость п болезиеность несколько уменьшились, по резкое ограниение подвижности н јевозиожность попьзоваться травмированной копечиостью прн работе остллись. В дальнеішем к зтому зрисоединилось и зна-

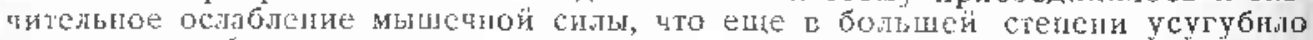
нетрудоспособность.

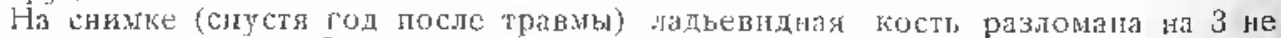

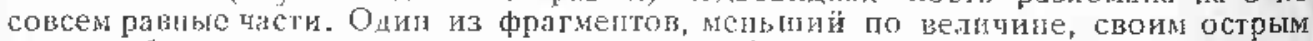
краем, обраленным в локтевую сторону, как бы вклинияся аежлу двумя остальпыми. Края разлома без четких контуров. Между несросшинися отломками щңель, в $1 / 2 \rightarrow$; м.

Yutzeler, изучая причины пссндортроза после перелома ладьевидной кости, считает, что наклонность к образованиго ложного сустава зависит от нещостаточного образования костной мозоли при одновременном неблагоприялном механическом моменте 
яследствне тяги суставных сунок. Нсследование автора обна ружило настолько обиирное кровоснабжение ладьевидной кости, что оно не может служить прициной образонания пожиого сустава. Псендортрози наблюдаютс преимунественно после поперечных переломов os naviculare. При этом линия перелома проходит между обеими суставными сумками и соответствующими связтами, сосдиняюлими ладьевидную кость в проксимальном налрашлении с лучевой, а в дистальном-с многоугольной костьо. Вследствие тяг их возникает dislocatio ad long. cum distr.

В практическом отношении, следовательно, важно помнить, что все попереиные переломы, проходяиие через средину тела ладьенидной кости, необходимо длительно и тщательно фиксировать, тогда как остальные переломы этой кости должны хорошо срастаться и после 2-3-недельного покоя. ІІри отсутствии лечения образование костной мозоли может наблюдаться лишь шри особо благогриятных условнях, из которлх прежде всего необходимо указать на сколачинание отломков.

Приведенные выше теорстические предпосылки намечают и опредетенную линию поведения практическоло врача при лечении свежих переломов ладьевидной кости.

Выбор метода фиксации нрид ли имеет в даниом случае рецаныцее значение. IІри поперечных переломах в средней части с расхождением отломков, т. е. в случаях, где требуется длительная фиксапия, мы предлочитали пользоваться круговой гилсовой повязкой, наложенной приерно от границы нижней и средней трети иредилечь до пястно-фалангового сочленения. Тақим образом папњ и локтевой сустан оставлялись совершенио свободными, чро давало возможность производить движения в них с первых же дней после иммобилизации. Фиксация с периодитеской сменой повязки для рентгенологического коптроля продолжалась в среднем от 6 до 8 недель. Во всех трех свежнх случаях поперечного перслома в нашем материале в результате проведеиия указапио̆ методики лещения отмечена консолидация отломков и полнос восстановление трудоспособности.

В остальных трех случаях, касающихся отрывов небольших периферических фррагментов, дело ограничилось наложением тыльнои шинин по Розеру на $18-20$ дней с послелуицим физиотерапевтинским печением (массаж, ванны, гимнастика). В двух провсренных на рентгене случаях мы имели также restitutio ad integrım. В застарелых и далеко зашедших случаях перелома лальевидной кости Л Іолано считает паиболее целесообразным способом лечения просверливание нссросиихся отломов по Беку с поспедуюпей фиксащией сустава на 5-6 недель. Преимуществом сиособа автор синтает технисскую простоту, надежность и безопасность вмешательстиа. Мы не ирибегаем к оперативному лечению лереломов ладьевидной кости, и своего опыта в зтом вопросе не имеем. Наличие псевдоартроза в нашем материалс отнечено 2 раза, причем один из больных после 1-го обрапения большс не явилс. Сушествование ложного сустава 
зо втором случас цикаким расстройством не сопровождалось и леченя не требовало. Таким образом, поделиться опытом в леценин переломов этого рода мы не ножем.

Наш материал нооб̆це пебольший, и делать какиельибо выводн, основываясь на нем, трудно. Одлақо он демонстративет В том отношения, что: 1) в нем доминируют по преимуществу свежие случаи изолировапиых нереломов ладьежидной кости, сносвременно и иравильно распознанные и надлежалим образом леченың и 2) эти персломы пост все ирослежены до конца.

Әто дает нам некоторые основания утиерждать, что при своеврсменной дияннотике соотнетствуюлюе лечение перелома ов naviculare дает вцолне блалолриятые результаты. Hабборот, случан своевременно не распозниныле и залуценнце, как правило, бонталте псендортрозами со исеми вытекатоцими отсюда пос.'едствиями.

Литература. 1. Дьяченко В. А., Ортонед. и аравм., жол. 4. 1929.-2. Заркевнч Н. Ф., там же, кн. 2. $1934-3$. Колонлзь А. М., Нов. хир. архия, т. 38 , кн. 3 1935,-4. Сорокни А. 3., Воснно-медид. журнал, том III, вил. 2, 1932.5. Тоцтий В. М., Харьков. мед. журн, том 15 кн. 3 1913.-6. Миронов Е. Я., Coнет. хнр., том 3, выл. 4-5.-7. Минина Р. М., Там же, кн, 11, 1936.8. Cupey H., Mischr. Unfalish 1. 1935,-9. Yutzeler H., Dtsch. Z. Chir, 1932.10. Polano H. K. Der Chirurg. 8. 1935.-1I. Thompson J., Amer. I. Surg W. S. 21. 1933.-12. Schneck F., Zbl Chir, 1933.

Из тереой хирущияескй киинки Одеского мединститута (директор щроф. H. H. СоKOilOB).

\section{Хронические абсцессы грудной железы.}

\section{Л. Е. Корыткин-Новкков и О. А. Бродский.}

Хронические аосцессы грудной железы предстанияот большой практический интерес. Это заболевание встречается далеко не часто. Так, по статистике لенормана из 175 поражений грудной железы 121 падает на рак грудной железы, 50 случаевна острый мастит илишь 4 случя на хронический абсцесс.

Iредставын собон онень часто картину, сходную с раком грудной железы, заболевание это ошнбочно дает повод к совериенно напраспону радиканному опсративному вмешательcTBy.

Статистические данияе показывают, что в наилучшим образом оборудованных клиниқах опибки диагноза рака грудной железы, как иравило, бывают в прелелах от 6 до 12\% (Герцен).

Опикки прижнзненного распознавания з.окачественных новообразований вообце состанлякт: по русским даннлм-13,9\% (Меріов), по германским- 13,2\% (Любарш), по английским-от 20 ло 28\% (Мейер, Джилфорд), пाо американским-20\% (Вуд). Телерь, благодаря методам скорой патолого-морфологической диаюостики злокачественных онухолей, процент ошибок в диагнозе снижается. 
При неясной картине заболевания грудной железы диатноз хронического абсцесса грудной железы не ставигся потому, что о нем не думают, а межуу тем по вышеприведенным соображениям он заслужинаст самого серьезного внимания со сторонь хирургов-клиницистов.

Зтиэлогическим мсментом данного заболевания могут быть: кормление грудью, острый мастит, различного рода травмғ и инфекция.

По Реклю, женпина, перенесшая мастит, сохраняет в продолжение многих лет инфекцию в патентном состоянии в тех неболыших плотных узелках, которые остаются после заболевания. Под влицниеи тех или иных причин эти узелки увеличиваются в обьеме, становятся чувствительными и преврашаются в небольпие абспессы. Такая картина может также наблюдаться и у жснцин, никогда не беременевших или не кормивших грудью.

Действие травмы представляется или в виде отдельных значительных ушибов, вызывающих гематомы, или же в виде множественных мелких травм, которым особенно подвержены большие, дряблые, значительн обиисшие груди полных женщин.

На таких грудных железах встречаются экскориации, экзема подгрудной складки, могущие вызвать лияфангоит, в свою очередь ведущий к образованию хронического абсцесса. В прежнее время иножественные мелкие травмы причинялись нередко давлением металлических пластинок от корсета.

По Лесену, общая инфекция, как грипп, ангина и др. может играть этиологическую роль в развитии хроиического абсцесса.

Исследования Рона, ГІассэ, Кзстлина, Нойфельда и др. показывают, что в гное абсиессов грудных желез могут быть находимы стафнлококки, стрептококки, руосуапеus и тенококк.

Б. Эрихсен различает даже две формп хронического абсцесса грудной железљ: хронич. разлитой абсцесс и хрон. инкапсулированный. ІІерная форма, ио его мнению, встречается во всех возрастах как у замужних. так и у незамужпих женщин, развивается в клетчатке позади грудной железы и исходит в больцинстве своем из ребер ${ }^{1}$ ). Вторая форма развивается в самой железе из безболезненных, медленно увеличиватицися затвердений, которые в течение целых месящев постепенно размягаются в щентре. Самуэль Гросс наблюдал последнюю форму абсцессов у молодых пезамужиих женцин, а также и у рожавших, особенно в той груди, которая во время кормления почему-либо мало функцнонировала.

Клиническая картина таких абсцессов представляется в виде небоньий, иногда крупной опухоли, плотной или упругой, иногда флюктуирующей, не спаяниой с кожей и подлежащими тканями, часто соверіпенно безболсзненной, покрытой нормального қвета қожей. І Іодмышечные железы могут быть увеличены; плотные, безболезненные, они иногда црезвычайно напоминают раковые железы. Дельбэ указываст, что характерным в данном

1) 110 существу эта форма ие отнаситея к маститам. Il р и м. редак ци и. 
случас являетси несоответетвие поражения лоды ышечных лим ратнчески желез давности пролесса в грудиой железе, а именно:

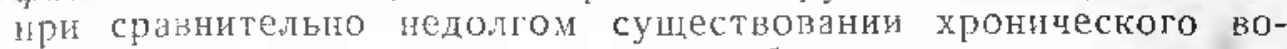

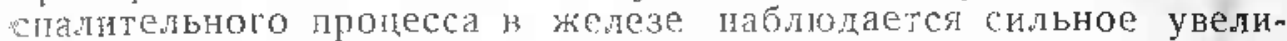
чение многчисленных шимфатических желез, не соответствуюшее развитию предиолагаемого рака.

Нанболее трудиы и ответственным является все же диферен-

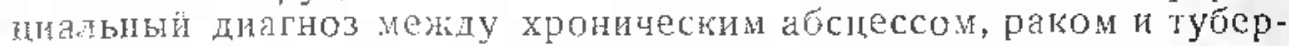

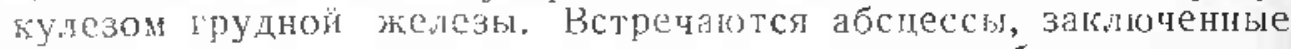
в очень плотную калсулу, содержащую весьма небольшое коли-

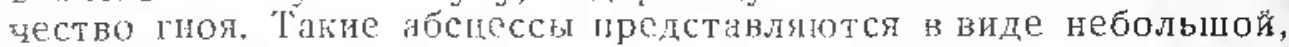
плотнй, совериенио безболезненной опухоли, без каких-либо признаков упругости или флкктуании, без резко выраженных

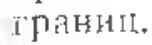

В связи с тем, что тание абсцессы встречаттся цаще у пожилых женцин в перноде менопаузы и сопровождаютсы иногда уреличнием подмышечных желез, имеющих при этом характер раконых, становятся лонятными те ошнбки, которые указаны виде и тоторыс далеко нередко ведут к слишком радикальному олеративному менательству.

Некоторье анторы указывалот подыеченнье ими отлиние.иние признак. Так, паприер, фока сиитает характерным дли абсцесса плоскостное срапцение с кожей, тогда как ири раке олухопь спакваетсл в отдельных точках фриброзныни отростками, илущими из плубины от опухоли к поке, причем кожа принимает вид апельсинной корки.

Необходия такке лиферепширвать абсыесс железы от туберкулезного заболевани, прсдстанляюшего инолда при распозназани знациедьные трудности, особенно в начальном іериоде развития. Со времен Дюбара, нлервыс описавшего туберкулсзное поражение прудной желези, нанболее характерным считается: 1) ранние явления шденита подмыленых желез, откуда процесс и начияастсл, пережоля потои на трудную железу; 2) многочисленность олагов поражения; 3) малая болезненность и торпидный эид всего шроцесса; 4) доџольно раннее вонлечение в иропесс кожи с последуицим образованием характерньх свицсй; 5) паличие туберкулезного прощесса в другх органах (легких,

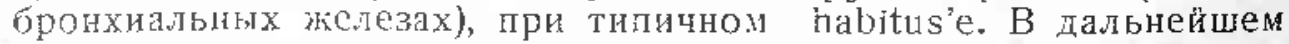
отдельһые узлы соединяются межху собою и имеют тенденцио к размягчнию, зследствие развития пропесса творожистого перерожделня: полость такого очага содержит обычно казеозные массы. Весьиа нередко вокруг центрального фокуса разиягчения имется более свежие, еще плотные бугры. Оконцательная диагностика ставитя на основания микроскопического исследования содержимого и гистологической картины срезов.

Одиако Ленориан считаст все әти признаки недостаточными для установени точного дианоза, так кақ и свосвременно произведеный пробыны прокол инолда не дает положительного результата ввиду присутствия незначительного количества и нногда тусгого гноя, как это было у двух из наших болығых. 
В таких случаях можно рекомендовать широкий разрез подозрительного узла, как первый этап могущей понадобиться радикальной операции, о чем заранее должна быть тредупреждена больная. В случае, если разрез показывает наличие злокачественлого новообразорания, макроскопический вид которого бы вает характерен, тут же приходится рану закрывать щищцами Мюзо, меныть перчатки и илструменты и производить ехегеsis mammae a distance. Произведенный таким образом разрез не ведет к диссеминации опухоли. Такой разрез уничтожает сомнения, если қаже не огределяет рода опухоли.

Проф. Соколов рскомендует полное иссечение такого абсцесса вместе с капсулой, $\uparrow$. к. разрезы без вылуцения капсулы иногда дают долго не заживающие свищи. Экстирпация опухоли-гнойника была проведела в двух из наших случаев (у б-ных ЏІ-дт и В-вой), где мы получили гладкое послеолерационное течение и заживление ран per primam intentionem.

Интересные примеры ошибочной диагиостики можно привести из литературы.

Слуцаи, сообшаемне Јенорманом: I) Б-ная, 21 гола, опухоль груди. Опухоль небольшая, уплэщенная, улругая, совершенно безболезненная, покрыгая нармальной кожей. В подмышечной обласии с обеих сторон пропупываются небольшие лимфттические железы.

Диалиоз: киста трудной железы. ['ри операции-вылущение опухоли-был вскрыт карман, из которого ныделился гной.

2) Женщина, 45 яет, постули ла по поводу опухоли грудноз железы, Опухоль луотная с јеясными гряницами, бугристая, безболезненная, не спаянная с грудной мышцей, покрываюцая кожа свободіа. Юрощулываются плотныс пакеты подмышечных желез.

Диаг:оз: Cincer mammae. Слелана радикальна операция: ампутация грулной железы с удалением обеих грудых мышц. По вскрытни удаленной опухоли обнаружены абсцессы. наполнешыс зеленоватым гноем.

Сулружинский из Нежинской окружной б-цы сообцает о б-ной 24 лет, лостуиивлей для операции по поводу опухопи правой грудной железы. Опухоль с теченисм времени заметно увеличивалась. Олухоль плотная, безболезнення, без резких гранищ, не спаянная с кожей. Сосок не втянуг, выделсний из него не замецалосқ. В подмышечной впадине несколько плотных лимфатилеских железок. Во врсмя операини калсула прорвалась и оттуда вытек серовато-желтый гной.

Aнгерер сообццет о больной 39 лет, у которой во время послецней беременпости в правой грудной железе образовиля плотный узел, быстро увеличиваюпийся. Кожа сращена с опухолью, железа фиксирована $\mathrm{k} \mathrm{m}$ pect ralis m jor. Подмышедные лимфатические железы увелитены, сосок втянут. Прокзведена ампутация патmде с вылущением подышечных лимфзтическх желез. На разрезе прспарзта незначительное количество гноя. Микроскопическим иследованием обнаружено обильное развитие соединитсльной ткани с воспалительной инфильтрацисй.

Среди нсех заболеваници үрудной железы, наблюдавшихся нами за последние пять лет, интересны метыре случая;

1) Б-ная ПТ-скақ (ист. б-ни № 6355), 32 дет, поступила для оперэции по повопу оп хой левой грудной железы. Копсультацией с проф. Н. Н. Сокоговым и проф. Н. Н. Исаченко постален бы. диягіоз сапсет mam. sin. н больной предлодена бына операция удаления грудной железы, В анамезе нет указаний иа какос-либо заболевание грудиых желез в прошлом. Из перенесенных заболеваний отыечает: корь, брюшной тиф, троекрлтное заболевание воспаленисм легких и экссудативное воспаление плевры. Условия работы и жилицнобытовые хорошие. 
Б-ная гравильного телосложения, удовлетворительного питания. В легких имеюгся сухие рассеянные хрипы, особенно в Залних шастях, и явления сухого плевриха В сердис изыенений не обнаружено. Со стороны органов брюшной

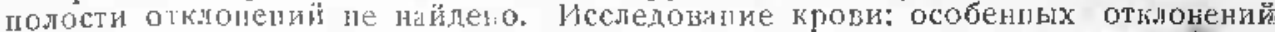
пс обнаружено. R W отрицтсльная. В левой грудной железе, в всрхие-вну-

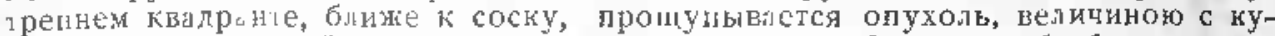
риное яйц, пнотнӧ консистенции, мло лодвижна, бугристая, безболезненая, с кожей не спаяная. Сосок пезијцисльпо втянуг. Аксилярные слева лимфатипеские жетсзы увеличены, цлотыы.

Б-ная подвергнута предвиритльной rлубокой Rö-терапии по Винцу (полулила 4 сеанса), и на 8-й день произведена операция. На разрезе преларата обнаружепо песколько узиов, заключающих в себе небольшие полости, наполmentise riocm.

Гистологичесое исследование: преларат иредславляет собою участок ткани грудной жслезы с редко встречаюимися нзиенивиими свою форму железистыми элементами, Знафитсльне развитие плотной, зредой соединияельной тканя, окаймляюцей в видс калсуды отдельые онаги. На лреларате мусылирует вослалительтый шроцссс, который о отдльных местах представляет собою мошиые сколления гнойыл тслец, пимфоцитов, лейкоцитов. Клеток бластоматозного роста пигде не обнаружено (Серебряников).

2) Б-ная Б-сс (ист. 6-ни № 986), 48 лет, постулнла для оперативиого лечения по поводу опухоли левой грудной железы, которую она заметила $4 \mathrm{M}$-ца назад. Олухоль довольно быстро увеличилась. В прошлом, 10 пет тому назад, отмещат заболевание гнойым маститом этой же груди, по поводу которого тогда оперировалась. Ilосле этого считала себя все время злоровой, имеет 4 детей. Бз-пая правилього телосложения, внолие удовлетвориельного питания. Со стороны сердла, дегких и других ор: анон изменений нс обнаружено. Анализ крови: изменсний со стороны белой и красной крови нет. R. W. отрицительная. В лсвой грудной железе, в нижнеларужном жваданте, обнаруживается опухоль с курипое яйно. Опухоль неправильой круглой формы, бсзболезнеиная, товольно плотная, с кожей не сляяная. Подмышечиые лимфатические железд слева увешиныы, ясно прошупываются. Диагноз: са патmaе. До операции б-ная полуикла 5 сеансов глубокой Rö-терапии.

На 8-й день операция; до раликальпой операции сделана пулкпия опухоли, которая результата не дала. ІІроизведена только amputatio mammae sin. без удаления лимфитических желсз (ло Винцу).

На разреsе препьрата в лептре опухоли оказалась полость, налолнения густьм гноем. Исследовапие гноя, бактериоскопическое н путем посева, показало, что гной стсричьный.

Гистологическое исследонание опухоли: на препарате имееся богато развнтая. волокнистая соединительна ткань с ясно вилимым воспалением, и только в отдельных участках сохранела ұормальня слруктура грудной железы. Прнзнаков злокатествениого роста в препарате ие обиаружено. (Серебрянииков).

3) Гз-ная IHІ-дт Е. М., 53 л. (ист. б-ни № 7612), уиительница. Постулила по поводу опухоли правой грудной железы, которую заметила три меслца тому назад. Oпухоль за это время незнанительно увеиичилась. Ральне никакими инфекционными заболеваниями не болена. Рожала три раза, имсет двух взрослыхдетей. При жормлении последнего ребенка 5 лет тому назад были трецииы и небольшое воспалиие в области соска правой грудной жслезы, которое довольн скоро пролло без операции, шричсы кормленис она не прекращала. Все время считала себя совсршенно злоровой.

Б-ная правнльного телосложения, удовлетворительного питания. В сердцс и летких, а также в орган брюпной полости измелений не обнаружено. Ајлиз крови: патологических явлений не обнаружено. $R$. W.- -отрияатељьня.

В правой грудной желсзе, в нижне-внтрсннем квадранте ее, имеется опухоль, величишою с куриное яйцо, при пальпации безболезненная, бугристая, мало лолвижная, сосок чуть втянут. Подмынечные пимфатические желсзы увеличены

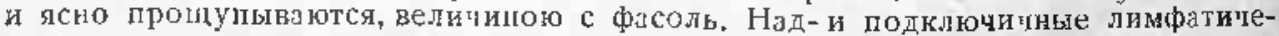
ские железы не прощупываются

Диагноз; carcet mam. dex. Б-ная погухила предварительио 4 селиса глубокой Rӧ-терапии (по Винцу).

На \&-й день-операция. Сначала пронзведена пункция tumor'a, при посредстве 
которой в щприц добыт густой с желтоватым оттенком гной. Дальше пе наружно̆ новерхности маmiюае произведен послойный Warren'овский разрез, доходяпий до опухоли. Опухоль выделена и удалена целиком. В полость, где была эпухоль, введен тонкий дренаж на сутки. Швы, асептическая повязка.

На разрезе прсларата обнаружен один узет, содержащий в себ́е полость, нашолнену ю густым гноем.

Гистологическое исследование; на срезе, сденанном из стенки опудоли, ткали нормальной грудной железы не видно. Обнаружено довольно большое количество соединительной ткани, пронизаниой гнойными тельцами и лимфоцитами. Sісно заметыа картина воспалительного лропесса. Бластоматозного пронссса нет. (Заевыошин). Бактериологическое исследование гноя: гной стерильный.

4) Б-ная В ва, 26 лет (ист. б-ни № 158), поступила по поводу замеченной ею 6 месқцев тому назад опухоли величиною с орех в правой грудной железе. За это время онухоль значительно увеличилась. В прошлом никаких инфекдионных заболеваний не отмечает. Лет семь тому назад, в прнвую грудную железу имела упиб, сопровождавщийся кровоподтеком; замужем 3 года, ле рожала, имела два искусственныд аборта.

Б-ная хорочего питания, правильного телосложения. Со стороны сердца, легких и лр. органов отклонеңий от нормы не обнаружено. Анализ крови: лейкоцитариля формула без особенных изменений. К. W. отрицательная.

В правой грудной железе, в верхне-наружном квадранте, имеется впухоль с голубнное яйцо, плотноватая на ошупь, безболезненная, чуть бугристая, іғоти гравильой круглой формы, с кожсй не спаянная.

!роизведенной на операционном столе пуикцией опухоли добыт сливкообразный гюой. Через радиарный разрез лроизведено вылущение опухоли. Цренаж на сутки. Рана зиита. Асептическ я повазкӓ. Макроскопическим обследованием опухоли установлшо, тто мы имеєм дело с осумкованным абсдессом. Гистологюсское исследование: на срезах, взяых из разных удастков стенки опухоли, видно большое развитие зрелой соединительной ткани, и только местами изрсдка имеются скопления гнойных телец и лейкоцитов. Видна картина воспалительного процесса. Бластоматозного росты нет. Нет также признаков туберкулезного процесса. (Засвлошин). Бактериологическое исследование показало, цто гной стерильный.

Как видно из кратко приееденных историй болезни, ошибодно диагноз был поставлен В первых двух слуиаях и правильнов третьем и четвертом. Хотя во втором случае, имел опыт одного случая, мы уже думали о хроническом абсцессе, но произведенная пункция, ввиду наличия густого гноя, нам в постановке диагноза не помогла. Все это лишний раз показывает трудиости, которые встречаются на пути постановки диагноза этого довольно редкого заболевания, и говорит о необходимости помнить о хроническом абсцессе при определении характера опухоли грудной железы. 


\section{$-1442=$}

Из клиники болезней носа, горла и ушей Казанского госуд. медицинского ннслитая и Йı-та усовершенствовиния врачей им. В. И. Ленина.

\section{6 инородных телах трахеи и бронхов.}

\section{Проф. В. К. твутнев.}

По вопросу об инородных телах трахси и бронхов накопилась очень болатая литсратура. Особенно больюе количество работ по этому вонросу появилось за последние 20 - 25 лет. Казалось бы, что нет нужды возврацаться $\mathrm{k}$ даниой теме. Тем не менее мы позволяем себе занять ен внимание читателя, так как некоторые вонросы той сложпой проблемы не получй единодушного разрелисни, а также и потому, что материал концентрируется по преияушесту в специлыных журналах, мало доступных широкому пругу врачей. С больными же, носителями ннородных тел трахеи и бронхон, приходится иметь дело не только бронхоскописту, ларингоотиатру, но зачастую оказание помоши вынолнет хирург, а иногла и врач, не имеюций хирургической подготовки. l Іе лишним счйаем выступить и потому, чло в нашем раслорлжения оказдлась относительно немалая коллекция инородных тел, извлсченных из трахеи и бронхов.

Поставить диагноз инородного тела трахеи и бронхов, как известн, в большилстве случаев не трудно. Здесь врач базируется главным образом на ананнестических данных. I Іропуская перед своим взором жлинический материал, прошедший в течение 20 лет, должен согласиться с тсм, что почти всегда удается безошибочно ставить дианноз только на основании одного анамнеза.

Дополнитепьные мероприятия, о которых речь будет ниже, лишь уточняли и подкрепляли предположение, высказанное на основании анамкеза. Харақтерным в анамнезе является неожиданное возникновение кашля, затрудиенного дыхания в той или иной стенени, а иногда к этому присоединяется и нарушение фонаторной способности. Все эти симлтомы возникают вдруг у здорового человека, который обычно сам указывает, что данные явления наступил после того, как был неуданно „ироглочен" какой-нибудь предыет. I Іоложение врача несколько осложняемс, когда доставлиот мзлолетнего пациента, аспирировавшего corpus alienum в отсугстии взрослых. Большим подсыорьем в таких слуцаях служит фјеномен флотирования. Мри кашле, плаче и смехе подвншные инородные тела очень часто вызывдот „щелканье“, возникалиее благодаря ударам инородного тела о сгенки дыхатсльного тракта. јЈиш в редких случаях этот признак мокет ввести в забиукдение.

Все же цолагатьс искліочительно на один анамнез не рекомендуется.

В октяре 1936 г. В Кузанскую ушную киннику явилась граяданка К., 45 вет, и сообщила, тто две недсли пазад, но время еды репы она поперхнулась. 
ІІоявилось значительное затруднение дыхания. Немедленно обратилась за помоцью в больницу, откуда была отправлена с предноложительным диагыюзом .инороднос тело трахеи “. В момент осмотра в клинике больная не имела ясно выражениог нарушелия дыхания. Пияиенка усиленно подчеркивлет ощушение неловкости в горле и неудобство при глотани справа. Под местной поверзностиой анстсзией произведена верхняя трахеобронхоскппия. Инородное тьло не найдспо. Отмечена небольпая набухпосюь слизистой оболонки подсвязонного иростаяста. Через два дня после операции больная выписана из клиники в

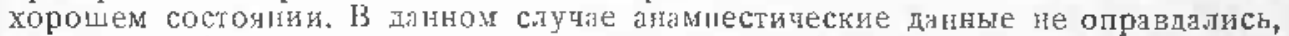
так как не бьло ыроявлено тштельнсти при собирании анамиеза Через день после операция больная сообиила об одной детали, о которой умолчала в момент постулнсния в клинику. Оказываетс, у больнй был бурный пристуи капля, и тогда, по ее словам, изо рта выскочил кусочек регы. Державдесея и посіс элого затрудненное дыхание обусловндось полсвязочным даринтитом.

Этот случай демонстрирует диагностическую ценность точного анамнеза при инородных телах трахеи и бронхов.

Поучительной в этом же отношении является история болезни мальчика P., 9 лет.

$17 / \mathrm{X} 27$ года больной был доставлеи в клинику с явлениями затрудщенного дыханя Родственници палисна сообпили, что в течение последыего дия ребенок был под набмюденисм бабушки. Накануне, вечерож, пеожидаино, во врсмя игры, у мальчики появились кашель и залрудненное лыхание. В кличику больной был догтавлен с предположительным дигнозом „инородное тело трахеи". Haше винмание было фиксировано ни повышенной температуре (до $\left.37,7^{\circ}\right)$ и на том обстоятельстве, что момент аслирации инородного тела никто пс наблюлал. В гортани обнаружсна пебольщя гйеремия сиизистой оболочки, $\mathrm{B}$ виду резко выраженного затрудиени дыхания решено больного подвергнуть брондоскоии. Верхняя трахеобронхоскопия, к которой прнступни без всякой анестезия, не удалась. При попығке введения броихоскопа в гортань у боньного появилась синюха и ос ановиа пыхания. Немсдленно произведена травеотомия с последующсй нижнй трахеобронхоскопией. Инородное тело не найдено. Трахея забита слизью и гноем. На стенках ее в нижгем отделе обниружены сероватого цвета пленки; біктериологитеское исследование материзла, взятого из трахеи, дало присутствие b. Lofflet'a. Исследование матернала из глогки и носа дало отрицательный результат.

Дважды находился в клииие пю излечении гр. С., 59 лет, поступивщий лервый раз 8/11 $27 \%$ Больной ири перном осмотре сообщил, что $20 / \mathrm{X} 26$ г. во врекя обеда закашлялся, почувствовав попзвиу у с пијей кость. Неудержимый кашель держался в течспис 2 часов сразу же иаступило затрудненное дыхание. В декабре ирисоединлась охриплость и в мокроте замечена кровь. Летился безуспешно. В прошлом, по заявлению о́льного, легкие были здоровы. 11од местной анестезисй четыре раза проияведена трахесбронхоскопия (19/1I, 23/1I,

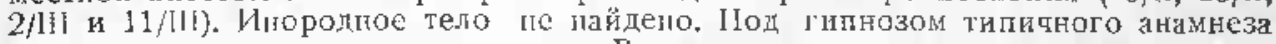
многокр'тно искай инородное тело. Видимо, оно во время кашлевого тодчка было выведено наружу, чего больной нс занти.

С мругой стороны, мы имсли больных, в анамнезе которых щри самом тцательном опросе не удавалось получить и намека на аспирированиое илородное тело. Больные бронхоскопировались по другому поводу, в связи с нагноительным процессом легкого. $\mathrm{K}$ удивленио больных, а также и хирурга иногда в бронхе обнаружньалось инородное тело.

Больной С. в течение ряда лет паходился под наблюдением очень опытного интерниста в связи с бропхоэктазами. Во время бронхоскопии из бронха этого больного была издепсиа больших размерлв говяжья кость. Только после операции больной вспомнил, что нацало легочного процесса совладает с моментом, когда он чем-то "подавился" н. охоте.

Прнведенные случаи пюказывают, что при всей диагностиче- 
ской ценности анамнез не всегда имеет решающее значение. Данные его должны быты подкреплень результатами других. методов исследования, из которых на первое место должна быть поставлена трахеобронхоскопия, значение которой увеличивается еше и тем, что она одновременно служит и терапевтической манипуляцией, лучшей из сушествующих.

Небеслолезны данные, которые мы в этих случаях получаем от перкуссии и аускультации. Почти категорически решаетсл вопрос, когда под влиянием инородного тела целитом выключается из акта дыхания все лелкое или один из его отделов. На осповани личного опьта и литературного материала у нас создалось впечатление, что такого рода инородныс гела встречаются редко. Чаше приходитсл иметь дело с инородными телами, которые по своему объему не представ.ияот пробки,

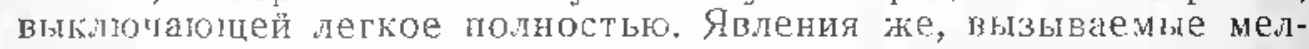
кими инородними телами, столь не характерны, что интернист на основании их не может дать определенного заклғчения. Уместно отыетить, что интернисты чаще склонны обращать вниматие на вторичные явлсния, упуская изииду перьоюричину, направля подчас действия лечацего врача-ларинголога на ложны远 путь.

Большие надежды в этих случаях возлагались на исследование рентгеноскими лучами. Нет сомнения, что каждый больной этой группы, если его состояние позволяек, долхен пройти через кабинет ренттенологы. В подходящих случаях мы получаем оцределенный ответ, удовлетворлющий нас. К сожалению, этот отьет мы мокем получить от рентгенлога лишь в неболынм количестве случаев. Современные возможности рентгенолога в этой области пока ограничень. Случалось, мы, как и другие враии, голучали отрицательный ответ, а через пекоторое время при помощи бронхоскопа извлскали инородное тело.

3a двснадцатв лст супествования Казанской ушной клиники зарегистрировано 55 больных $с$ диагнозом инородного тела трахеи и бронхов. Гор годам они расиределяютсі следующим образом: $1926-2,1927-15,1928-18,1929-3,1930-1,1931-5$, $1932-3,1933-3,1935-3,1936-2$. Из них мужчнн-33, женціин 22 .

Чаще всего носителями инородного тела были дети: до 2. лет-11, с 2 лет до $5-20$, с 5 до $10-9$, с 10 до 20 лет-7, сныше 20 лет-8.

Таким образом, положение, н свое время вндвинутое Готтштейном, сохраняеґ силу и по отношеник к нашему материалу. Как известно, им было собрано 111 случаев, которые по возрастному признаку раслределяются следугини образом: до 1 года-6, от 1 г. до $2 \%-11$, от 2 до 6 лет- 35 , от 6 до $12 \pi е т-$ 17, от 12 до 18 лет-6, от 18 до 63 лет-36.

Более $60 \%$ инородных тел трахеи и бронхов падает на больных в возрасте до 12 лет. Бріонингс, анализируя материал Готтштейна, справедливо подчеркивает, что наибольший подъем кривой оңносится к 2-3-летнему возрасту, и резко падает кривая 
ж 15-летнему возрасту. Прекрасной иллюстрацией в зтом отношении служат статистические данные Саратовской ушной клиники, любезно предоставлениые мне доцентом А. А. Потаповым: до 1 года. 6, от 1 l. до 3 л. -87 , от 3 л. до 5 лет-34, от 5 до 10 лег-14, свыше 10 лет-19.

Из сводной статистики Казани и Саратона видно, что 89\% всех носителей инородных тел трахеи и бронхов относится к пациентам до 10 лет. I Іонятно, какое огромное значение приобретает этот отдел для детских врачей, $к$ которым нередко в первую очередь являются такие больные.

Еще большее значение этот вопрос имеет для ларингологов, которым чаце всего приходится оказьвать радикальную медицинскую помощь носителям инородных тел верхнего дыхательного тракта.

Как было уже указапо выше, наилучшим из существующих диагностических и терапсвтических методов является трахеобронхоскония. $\mathrm{K}$ сожалению, әто исследование, ироизводимое на взрослых иногда даже в условиях амбулаторной обстановки, у детей сьязано с большими трудностями, иреодолеть которые пе ғ силах подчас и очень опытный специлист. Я имею в виду техннческие трудности нерхней трахеобронхоскопик у детей. Эти трудности стоят в связи с двумя основными моментами: во-дервых, не легко проводить трахеобронхоскопию на детях, потому что хирург принужден манипулировать в анатомически затруднительных условиях; иногда ириходится применять трубки с днаметром, не превынанщим 5-7 мм, при которых подробный осмотр глазом операционного поли почти невозможен или очень затруднен. Нужно обладать большой опытностью и находчивостъю, чтобы точно ориентироваться в такой об́становке. Второй момент, который затрудняет работу бронхоскописта на детях, заключается в том, что местное обезболивание на детях не цостигает пели, а общий наркоз чреват многими ошасностями пля подобного рода больных; мы никогда не применяем на детях местной анестезии, так как самая обстановка, в когорую попадает ребенок-пациент, так его нервирует, что эффект, получаемый от обсзболивания, сводится к нуло. Если ко всему этому прибавить обнлие слизи, появляющейся во ряу и глотке как во нремя введения инструмента, так и в последующем периоде, то стапет понятны стремление некоторых специалистон заменить верхнюю трахеобронхоскопию у детей нижней. Подкрешление своей позиции прсдставители этого течения нидят и в том, что иногда после верхней трахеобронхоскопии, произведенной на ребенке, приходится делать трахеотомию по поводу стеноза гортани, вознижающего на почве отека подсвязочного пространства. Как правило, мы применяли верхнюю трахеобронхоскопию на детях, хотя $\mathrm{B}$ единичных случаях в ближайшие сутки за зтим иринуждены были трахеотомировать своих пациентов. Удачно проведенная верхняя трахеобронхоскопия не только позволяет через $2-3$ дня выписать ребенка из клиники, но оснобождает его от многочисленных опасностей, связанных с 
наличием раневой поверхности и с нопением в трахее инородного тела (канюли), могущего послужить толнком к возникновению легочных налноктельных процессов.

Считан бесполезным местние обезболивание ири трахеобронхоскопии у детей, м катсгорически позражаем против шримепения общего наркоза и олерируем без всякой анестезии. Если приняь во ннималие, что в большинстве случаев через $3-5$ минут удавалось изнлечь инородное тело, понятн й стинет наша линия поведения. Ничем не олравдывается (кроме отсутствия техничсской подготовленности) применение обцело парқоза для операции, продолжительность которой не превышаст пяти минут. Нмеются при трахеобропхоскопии и особые условня, которые побуждакот возражать иротив общего наркоза. Носители инородных тел трахеи и бронхов нередко поступают на лечение $c$ явлениями знамиеньноло затрудпения дыхания и воспалительных процессов трахеи и бронхов. Гри этих услоциях малейшее ухудшение дыхания мокст оказаться гибельным. Общий наркоз, вклоча дентельность вспомогательных дыхателыных мынц, нногда сыужит тем последним толчкон, появление которого обусловливает смерть пациента при трахеобронхосколии в первые минуты ее производства.

Если вниматсльно просмотреть киинический материал бронхоскопистов, оперирующих детей лод обпци наркозом, можно найти у них подобные случаи. Обычно здесь станыт летальный исход в зависимость от других причин, Лет пятнадцать назад я имел полобный печалыный случай, и ни разу я не видел их с той порь, жак отказаля от применения общего наркоза. Насколько опасным является общи й наркоз при трахеобронхоскопии у детей, мокно видеть из следующего нашего наблюдения,

В клинику был достав

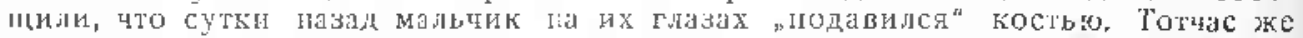

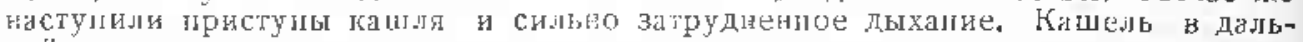
нейшем несколько умсньшися, явления Же затруденного лыхния остались без изменсиий. Обиее состонние больного тижелюе. Јјризаки кислородного голодания сильно выражены. Дыхание свистияе. Немедленно приступипи к верхией трахеобронхоскопии без всякой апсстезни. В лижнем отдсле трахеи

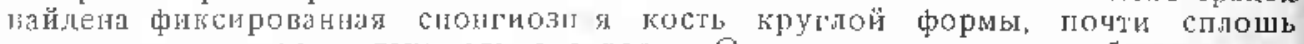
закрываюшая аросвет дыхательлого торла. Отдельными мелими зублами кость влилась в слизистую оболочку. Цьдание осуцествляется через отверстия, ограпиченые стенкой трахеи и отдельными мелкими шилами кости.

Можцо думать, что при общем наржозе в этом случае летальный исход блл бы некзбехен. В сьязи с ныключепием из акта дыхания вспомоталельных мыши н лодавлением кашлевого рефлекса организм при даныых условия оказался бы несостоятельны:.

Рекомендуя, как правило, верхнюю трахеоброгхоскопию у детей при инородных телах, иы предполагаем не только наличие хорошей технической подготовленности хирурга, отсутствие которой Якщ считает единстненым противопоказанием, но и обязательное производство данной операции в условиях стационарной обстановки, где в каждую минуту в случае нужды ква- 
лифицированный врач может произвести трахеотомию. Еще на заре трахеобронхоскопии шравильно было указано Калером на основании анализа немалого клинического материала, что у детей после производства верхней трахеобропхоскопии в некотором проценте случаев наступает стеноз гортани, требующий горлосечения. Обынно с зтим осложнением приходится иметь дело в первые 48 часов после трахеоброшхоскопии. С улучшением инструментария и повњшением технической ловкости хирурга этот процснт снизился, но не сведен к нулю.

В условиях работы периферической больницы, пе располагающей подчас инструментарием, а иногда не имеющей лица, владеющего техникой трахеобронхоскопин, врач должен, наи кажстся, вести себя следующим образом. Правильнее всего будет, если больного эвакуируют в учреждение, где может быть применена трахеобронхоскопия. Если же инородное тело фиксировано в гортани, больному должна быть вставлена трахеотомическая каноля, когда врач предполагает, что инородное тело мокет вызвать последулоций отек гортани. Только после этого пациент препровождается в распоряжение сиециалиста.

Смысл трахеотомии в этом случае лежит в том, что больной гарантирован от асфиксии, могуцей наступить из-за стеноза гортани, иногда быстро развиваюцегося при данных условиях на почне травмы.

В 1929 году нам пријлось встретиться со следующим случаем. Ребенок аспирировал инородное тело (семя подсолнуха). Был поставлен правильный диагноз, й гредложена рациональная медицинская помоць. Родители отказались дать разрешение иа ироизнодство операции и унесли ребенка домой. Через двое суток в клинику с криком вбежала мать, имея на руках поцти безжизненного мальчика, и сообщила, что 5-6 минут назад, после сильного приступа кашля, у ребенка внезапно наступило ухудшение дыхания, мдльчик посинел. Немедленно произведенная трахеотомия, несмотря на все принятые меры, не сохранила ребенку жизни. Инородное тело оказалось вклинениым в подсвязочном гространстве и как пробка закрынало просвет голосовой щели. Повидимому, это вклинение подвижного инородного тела произошло в момент приступа кашля. Поэтому в случаях с поднижными иноролиыми телами, могущими вызвать осложнение, ажалогичпе вышеописанному, можно рекомендовать врачу, работающему в условиях цериферической обстановки, производство трахеотомия. Нередко эта операция при цанном страқании можст увенчаться полным услехом. Нногда после рассенения колец трахеи во время кашля инородное тело выбрасығается из трахеи наружу. В других случаях, во время выдоха или кашля согрus alienum подводится к отверстию, проделанңому в трахее, и врач извлекает его пинцетом.

При инородных телах, находяџихся выше трахеостомы, обеспечивается пациеиту свободное дыхание. Для экстракции же инородного тела пациент в дальнейшем при спокойной бб́становке отправляется к специалисту. 
Мало эффективной оказывается трахеотомия, если инородное тело фиксировано в одном из бронхов. Но и здесь, пользуясь носовым зеркилом с удлиненымм браншами и освецая лобным рефлектором, можно при помощи изяцных корнцангов пытаться извлечь инородное тело. Некоторым слециалистам эта манипуляция удавалась. При неудаче больпй передается бронхоскопнсту.

Ленинғрадский обл, ииститут ОЗДиП (директор щроф. В. Н. Иванов).

\section{Ренматические пульмониты у детей.}

\section{Проф. А. Б Воловик.}

Секционный материал свидетельстнует с несомненностью, что ревыатический ироцесс поражает различіые отделы карлиоваскулирной системы, в том числе и крупные сосуды. С клинической точки зрения поражения этих сосудов и в частности легочной артерии представляют собой мало, вернее, совсем почти не изученную главу. Это отставание клияики от патологии не является случайным и обвясняется оцевидно теми затруднениями, на которые наталкиваетея клиницист, пытающийся распознать пульмониты при помощи обынных методов исследования. Об этом свицетельствует имеющаяся по вопросу о поражении стенки легочной артерии литература, относящаяся главяым образом к взрослым людям. Помнению Британишского, выслушиваемый при митральных пороках на легочной артерии систолический шум и акцент второго тона могут иметь различное происхождение. В известной части случаев әти акустические яв.ения возникают на почве расширения легочной артерии, которое обусловливается либо повышением внутрисосудистого давления, либо является результатом поражения сосудистой стенки-пульмонита. Рснтгенологически в том и в другом случае определяется раслирение и усиленная пульсация дуги легочной артерии. В условия хороџо компенсированного митрального порока систолический шум и акцент второго тона на легочной артерии в сочетании с рентгенологическими изменениями $c$ ее стороны указызают $c$ больной вероятностью на наличие пульмонита.

В иностранной недиатрической литературе, даже в специальжых монографиях, только нскользь упоминается о пульмонитах. В журнальных статьях имеется описание нескольких отдельных случаев (Агирре--Рикардо-Мосто). В советской педиатрической печати этот вопрос еще совершенно не освещен. Занимаясь юузуением заболеваний сердечно-сосудистой системы у детей на протяжении рида лет, мы имели уже случай подвести некоторые итоги в отношении поражений аорты и коронарных сосудов в детском возрасте. В настоящем сообцении мы имеем 
в внду поделиться наблюцениями над пульмонитами у детей в целях привлечения внимания педиатров к этому вопросу. Переходим к краткому описанию наших случаев.

1. Еюизавета Б., 13 лет. При ктиниеском обследовании обнаружено: сердедный тогчок средлей силы в 5 межрсбсрьи; сердце раслирено влево и вправо ңа $1 / 2$ см и вверх до з ребра. Систолическй шум на всех отверстиях серцда. Он синьнее и жестие па легочной артерии. Там же и резкий акцеит на втором тоне. ПЈулас удовиетворительный, ритминый. Печень не прощулывается. Рентгенологысски отмечаетс: митральная конфигурация сердца, умеренное уветнчение обоид желудочков и тевого предсердия. Дуга тегочной артерии выпячена и усиленно пульсирует.') Клинический диагноз: недостатопность двухстворки, пульмонит.

2. В. В., 16 л. Перенес скарлатину в 9-летнем возрасте. Порок сердиа обларужен у нальчика около 3 лст тыму пазад. Нспынвает одышку при физицески иалряенижх. При осмотрс сердечный толчок не сильный, в 5 межреберьи. Сердпе расширено умерепно влево и слегка влраво. У верхушки-систолический шум. На легочной артерии такой же, но елье более жесткий и сильный шум и резкий акцент на втором тоне. ГІульс ритмиянй, удовлетворительный, пе-

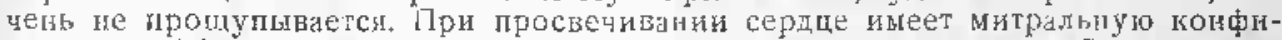
турадию. Оо́а желудочка и левое предсердие умерєно увелигены. Резко выступаст и сильно пульсирует дуга легочной артерии. Клинический дияноз-недостатониость двухстворки, цульмонит.

3. Д. К., 16 ฯ. В 11-летнен возрасге перенес первый приступ ревжатического полиартрита. Спуся 3 года-рецидив ревиатизыа, а за 4 яесяца до обследования в киинке-третьс обострение полиаргрита. При исслеловании отыечается расинрепие сердая влево на $1 \mathrm{~cm}$, вправо на $1 / 2$ см, вверх до 3 ребра. Ссрдечиый толчок средней силы в 5 межреберьи. у верхушии систолический шуз. На пегочной артерии этот шуя более жестий и сильный. Там же акцент на втором тоне. Пульс ритияый, удовлетворинелыный. Печень пе прощупываетсл. На экране определяется митралыая конфигурлция серда, умеренное увелидение левого желудочка и левого предсердия. Правый желудочек иезначиельно расширен. Дуга лсгочной артерии резко выступвет и усилено пульсирует. Кииническия днагноз: недостаточность двухстворки, пульмонит.

4. М. С., 13 я. В декабре 1936 г. перенесла ревматичсский полиартрит. Спустя 5 месяцев при кииническом об́лледовании ссрдце расширеюо влево на $1 / 2$ см, а вправо на । см. На лсгочной артерии выслучивается нсрезкий систолический шум и акпспт на втором тоне. Рентгеноскопия обнаруживаст умеренное увеличеиие правого желудочка и незначительное левого. Сердие имеет митральную конфигурацию. Lуга жегочиой артерни резко выступает и усиленио лульсирует. Клинический диагноз: ревматический миокардит, пульмонит.

5. ј1. К., 15 л. 5 лет перенесла скирлатину. Жануется на сердцебиение и одышку при беге и подъеме на лестниџу. Гри лервом осмотре в 192 г. границы серды нормальны, у верхушки и на лејоцной аріерии гыухо систоличсский шум. Максиму его на негочной артерни. Там же пкцеит на втором тоне. Пульс рнлмичый, уловлетворительный. При просвсчивании серлие нмеет митрзльую конфигурацию, размеры его не увеличены, Дуга легочной артерии выпячсна. Сиуся год, при повторном исследовании, со стороны сердца клинитески и рептгенологически те же измснения, что и раныше. При последующем осмогре по прошествин 3 лет систолйеский пум ша легочной артерии стал пссколько слабее. На экране отмечается иитральная коцфигурация сердца, обуслов.еная резким выпянивнием дуги пегочиой артерии. Последняя выполняет талию сердца в первом косом полюженин. Пульсация пегочной артерии знапительно усилсна, Размеры сердй все еще зампно не увеяичены. Еще спустя год-кинниески и ренгенотогически та же картина. Киинический диагноз! пульмонит.

Приведенные слугаи могут быть разбиты на 2 группы. К пер-

1) Рентгенолические исследования производились в рентгеновском отд. Ин-та ОЗДи!І или в кардиологическом отд. Гос. рентген, ит-та. 
вой относятся дети с пороками мнрального клалана, а ко второи-те случаи, где не имеетсл sных признаков клапанного поражения. Обцим для всей первой гругпы (З случая) является наличие относительг нерезко выраженной митральной недостаточности.

У всех детей отнсцастся небольиое увеличсние серцечных границ. У верхушки и на легочной артерии определяется систолихеский пуул, причсм на последней он сильнее и жестче, чсм на верхушке, и сопровождается более или менее резко выраженым акцентом второго тона. Рентеноскопия обнаруживает, как правило, отчетлиос выбухание дуги легочной артерии и усилеппуо ее пульсацию. Клинически и ренггенологически порок во Всех случая хорошо компенсирован, и иризнаки расстройства кровообрашения отсутстнуют полностью.

Спрашивается, можно ли на основании всех әтих данных утверждыть, что в наших случая имелось расширение легочной артерик на почве пушьхонита. При разрешенин әтого вопроса следует уиесть, что усиление или изменение тембра систолического шума на легочпой артерии по сравнению с верхушкой не указывают обязательно на расширение легочной артерди. Как свидетельствуют нашд наблюдения, в ряде таких случаев (у нас их бнло 8) при наличии указанных выше акустических явлений на легочной артерии рентгеноскопия не обнарухивала характерннх пля распирения указаниой артерии изменений. C другой стороны, при констатации этих измснений на экране систолическй̆ пум на лерочой артерии иожет быть мснее сильным и жестки, чем у верхушки, или он вовсе отсутствует.

В приведснных ныше случаяхакустическим явлениям со стороны легочной артерии сопутствовали и қостаточно резко выраженнье рентгілыогическе ее кзиенения. Это не оставляет сомиения в том, что у наших больных дейстнитсльно имелось расцирение легочной артсрик. Что же шасается ироисхождения этого расширения, то поскольу порок у всех детей был достаточно хороно компенсироеан и признаки расстройства кровообращения полностью отсутствовали, нет достаточных оснований считать, ио расцирсние леточной артерин нызиано значитсльным и стойким повынением виутрисосудистогодавления. Гораздо более веролтно прелполокение о том, что в основе этого расширения лежит пораженис стенки легочной артерии. Поэтому мы в согласин с Британишскин склонны трактовать указанные случаи как сочетапие недостаточности митрального клапана с пульмонитом.

Что же касается дстей второй групиь, то иітерпретация этих случаев наталкинается несомнегно на рsі затруднений. В случае 5-м цевочка находилась под нашим наблғдением на протлиенин 5 лет. Явлспия со стороны сердца и, в “астности, на легонни артерии держались все время стойко, не ослабевая заметно и не прорессирул. Констатированное на экране уже при первом осиотре вылячнвние луги легочной артерии в последуюшеи увеличйось еце в большей мере. Также возрасла 
и сила ее пульсации. В плане диференциальной диагностики надо прежде всего исключить врожденные пороки: стеноз легочной артерии, открытый Боталов щроток, незаращение межжелудочковой перегородки. Сделать это довольно нетрудно ввиду малой внраженности клинических явлений и их неизменяемости на протяжении пяхи лет. IІо этой же причине легко исключить и приобретеншый цорок-- недостаточность двухстнорки. Далее следует иметь ввиду фушциональные шумы, которые встречаотся в детском возрасте далеко не редко. Нельзя отрицать, что по характеру, тембру и интенсивности выслушиваемый у нашей девоцки шум можно легкј принять за функциональный. Акценгу на втором тоне легонной артерии нельзя приписынать особого значенил, т. К. в детском возрасте при известных условиях он может рассматриваться и как физиологическое лвление. Супественную роль играет здесь, конечно, обнаруживаемое при просвечиваник расыирсние легочной артерии.

Вірочем не следует упускать из вида, что выпячивание дуги легочной артерии может наблюдатьсы и у детей со здоровой сердечни-сосудистой системой на почве врожденной аномалии развития: неправильного деления сосудистого ствола и в связи с зкстракардиальным туберкулезным процессом (Шенфельд и Франк). Наряду с эгим цирротицеские процессы в легких специфического или неспепифического характера могут привести к рубцовому смещению легочной артерии, а отсюда-и выбухание ее дуги на экране (Гольст). ІІименитсльно к нашему случаю все эти факторы довольно легко исключить, нвиду отсутствия явных туберкулезных измснений в легких или цирротических процессов в них. Нарастание же рентгенологических изменений со стороны легоцной артерии свидетельствует против врожденной аномалии развития артериального ствола в нашем случае. Гаким образом шутем исклочения мы приходим к выводу о том, что у этой больной дело тақже илет о пульмоните.

У второй девочки отметася нерезко выраженный ревматический миокардит, а клинические и рентгенологические яаления со стороны леночной артерии были анылогичы тем, которые наблюдались и у других четырех детей. При трактовке этих изменений можно сослаться на соображения, высказанные по поводу предыдушело слуцая. Как и там, здесь нетрудно исключить врожденные пороки, недостаточность двухстворки, рубцовне смепения легочной архерин и т. п. Поэтому и данный случай, опять-таки путем исключения, мы склонны рассматривать как пульмонит, присоединившийся к поражению миокарда.

Описанными выне наблюдениями не исчерпывается наш материал по пульмонитам. Мц выбрали из него для опубликования лишь те случаи, где наличие пульмонита не вызвало у нас особых сомнений. Надо, конечно, оговориться, что и у әтих детей диагноз пульмонита является до известной степени предцоложительным, так как во всех случаях отсутствуе секционное подтверждение. Как бы то ни было, наши наблюдения свидетельствуют, что распознавание пульмонитов у детей представляется 
далеко не всегда пегкой, а подчас и вовсе неразрешимой задаџей. При наличии систолического пума, акцента второго ғона легоннй артерии и соответствующих рентгеногических изменений -.. ныпяциание и усиленная пульсация дуги легочной артерия,-если при этом не имсетсл признаков расстройства кровообращения на почне порока клаланов или поражения сердечной мышцы, можно с достаточной вероятностыо диагносџировать пульмонит. В том же случае, когда плинические явления со сторонь легоциой артерии оказывалотся недостаточно ныраженными, а на экране определяется вылячивание қуги легочной артерии, для постановки диагноза пульмонита необходимо предварительно исключнть все другие пропессы и состояния, которње могут вести к появлению указанных рентгенологических изменений. Наконещ, при недостаточности сердечной мынцы и на„ичии явлений расстройства кровообращепия прижизненлая диагностика пульмонита вряд ли пвлетсл возмокной.

Если попғтаться провести сравнение между аортитом и иульмонитом в плане их клинического распознавания, то нужно отметить, что диагностика аортита базлруется в значительной насти случаев только на рентгенологических данных.

К.нстатания на экране диффузного расцирения грудной аорты, а чаще--расширения и усиленной пульсации ее восходяпего отдела, позволяет при отсутстнии поражения аортальных клапанов диагносцировать с достаточно большой вероятностью аортит. Әта диагностика облегчаеся супественно в том отношении, что не существует други процессов, которые в таких условиях могли бы шривести к расширению аорты в целом или ее частей, помимо аортита. При распознавании гульмонитов приходится. однако, учитывать, как упоминалось выше, что пелый ряд экстракардиалын процессов слособен обусловить появление на экране выбухання дуги легочной артерии. Поэтому дианносику иульмонитов приходится базировать в зиачительно большей мере, чем при аортитах, на синтезе клинических и рентгенолоуичесих изменений, конечно, с теми огонорками, которые был высказаны ранее.

Как видно из нащих наблюдений, пульмониты в подавляющем большинстве случаев ирисоединяются, а быть может, и возникают однеременно с поражением клапанного апларата нли сердечной мышщы (в четырех наших случаях из пяти).

Литературные дынные также указыналот на относительную редкость изолированных пульмонитов.

Если при жортитах нам удалось показать, цто присоединение их к клананным порокам может иметь место как в недалеко зашедших случаях, так и гри комбинированных прогрессируюцих пороках, то в отношении пульмонитов мы лишены такой возможности. При наличии расстройств қронообращения нельзя высказаться определенно о характере констатируемого клинически и рентгенологически расширения легочной артерии.

Что касается исхода пульмонитон, то судя по нашему 5-му случаю, они шрнводят, понидимому, подобно аортитам к стой- 
ким изменениям сосудистой стенки. Окончательное суждение по этому вопросу станет возможным лишь при дальнейшем накоплении соответствуюияего материала.

ІІрогноз артериитов легочной артерии сам по себе, повндимому, благоприятен. Об этом свидетельствует тот же случай 5-й, где, несмотря на ıрогрессирование расиирения легочной артерия, размеры сердща не подвергались изменениям, а деятель ность его не ухудшалась на протяжении 5 лет. Позтому при оценке состозния сердечно-сосудистого больного ребенка норажение других отделов кардиваскулярной системы играєт значительно больпую роль, чем иульмониты.

По поводу этиологии последних у нацих детей сомнения могут быть только в отношении одного случая № 5. В анамнезе этой девочки из перенесенных заболеваний отмечалась только скарлатина и цритом за 5 лет до обнаружения унее пульмонита. Никаких данных, свидетельствующих о наличии у ребенка туберкулеза нли сифилиса, нет. Отсутствуют также и какие-либодругие ироявления ревматизма. Поэтому вопрос о том, существует ли в данном случае непосредственная связь между пульмонитом и скарлатиной или же артериит легочной артерии представляет собой единственное проявление ревматизма, приходится оставить пока открытюм. В остальных случаях сочетание пульмонита с ревматическим миокардитом или митральным пороком не оставляет сомнений в его ревматической әтиологии.

В начале настоящей статьи мы упоминали, что в клиническом изучении ревматических поражений больших сосудов делағся только нервые шаги. В этой связи намечающиеся из. наших наблюдений выводы носят, разумеется, предварительныи характер. Дальнейшая углубленная разработка клиники ревматических сосудистых поражений $\mathrm{y}$ детей несомненно внесет сюда ряд ценных дополнений и коррективов.

Быводы. 1. В ряду клинически выянляемых пораженй сердечно-сосудистой системы при ревматизме у детей определенное место должно быть отведено и пульмонитам.

2. Артерииты легочной артерии присоединяютсл в подавляющем больцинстве случаев к поражению клананов сердца или его мышцы. Как изолированное заболевание они наблюдаютея ловидимому редко.

3. Клинически при пульмонитах онределяются систолический шум и акцент второго тона на легочной артерия. Рентгенологически пульмониты характеризуются выпячиванием и усиленной пульсацией дуги легочной артерии.

4. Следует однако иметь в виду, цто появление систолинского цума и акценга второго тона на легочной артерии не указывает обязательно на ее расширение, а паблюдаемое на эжране вылячивание дуги легочной артерии может вызываться разлицными экстракардиальными шроцессами.

5. Сочетание указанных вые клинических и рентгенологиче ских изменений является поэтому нсобходимой предпосылкой в постановке дианноза пульмонита. 
6. При наличии этого сочетания распознавание пульмонита, ассоциируюнегося с пороками митрального клапана или с поражением сердечной мышцы, может быть проведено только при отсутстви гризнаков расстройства кровообрашения, т. к. н этом случае отсутствуст повод к повышению внутрисосудистого дав.ения, способного обусловить распирение легочной артерии.

7. Пульмонит, кақ изолированное заболевание, может быть диагносцирован лишь путем исключения всех других состоянй н прогессов (врожденные пороки, туберкулезные изменения в легких, цирротические процессы в них и т. д.), которые могут вызвать сходные клинические или рентлелолические изменсния со стороны легочной артерии.

8. В результате перенесения пульмонита могут наблюдаться стойкие и нсобратимые изменения стенки сосуда.

9. Непосредственый прогноз пульмонита следует считать благонриятным, ввиду относительно небольшоло влияния, оказываемого им на дсятельность и состояние сердечно-сосудистой системы в целом.

Лumepanypa, 1. Британичски , Сов, врат, газета, № 7, 1934 г,-2. Гольст. Клинитеския мсдиц., т. XI, № 5 6, $19^{\prime} 3$ r.-3. Aguire - Ricardo-Mosto, Zent. f, Kinderh-B. 99. H. I. 1934 Г.-4. Schonfeld u. Frank, Monát. f. Kinderh.-B. 67. $411-414,1936$ г.

Из Саратовского туберкулезного института (директор А. Михаймов).

\section{Эдоназальный метод применения туберкулинотерапи у детей.}

\section{Е. Н.. Липовецкая.}

В области туберкулипотерапии детей были периолы увлецений ж разочарований, и до сих пор не выработаны ни единая методика, ни формы ее применения, ни дозиронка.

Туберкулинотерапия путем втирания равных частей туберкулина и ланолина (Петруики, Медовиков, Кресслинг) пе дала нам опутительных результатов.

Распространенный способ лечения туберкулином-подкожный в детском возрасте иало применим, так как, несмогря на высокие разведения, все же получается обострение процесса и резкая общая реакци. На основе нашего опыта мы пришли к следующему убеждснию: если при туберкулинотерапии взрослых в вопросе об анәргизирующей или аллергизирующей терапии можно еще спорить, то у детей, где мы имеем лело преиму шестненно с формами туберкулсза, протекающими с аллергией типа Ранке II и лде постоянно возможна тендепция к генерализащии прощесса, надо стремиться к понижениг специфической і неспецифияеской чувствительности.

Соглашаяь с Гайеком, считающим, что задача сиецифической терапия заключается в том, ұтобы подавлять неблагоюриятные 
реакции, усиливать благоприятные и увеличивать выносливость к туберкулину, мы считаем, что добиться этого при подкожном введении туберкулина необычайно трудно, даже при предварительном исследовании туберкулинового титра в каждом отдельном случае. Вот почему, получив неблагогриятные результаты при подкожиом методе, мы продолжали искать другие способы применения туберкулина, Познакоминшись с әндоназальным слособом применения туберкулина (Иванова „Врач. газета“. № 20, 1933 г.), при котором, по мнению автора, мокно применять большие дозы, не опасаясь реакции, мы решили исіытать его, расширив показания.

„В более редких случаях применяется иммунизация через слизистую носа (Дзжержговский, Рамон-против дифтерии) или через слизистую зева (Бслоновский-против скарлатины). Однако последние методы не имеют серьезного значения, так как при них невозмокно учесть количество поступающего антигена. Поэтому Рамон рекомендовал свой способ лишь в тех редких случаях, когда все другие методы иммунизации почему-либо нелсупествимы (Коршун-Б. Мед. Әнциклопедия).

Мы отдавали себе отчет в неточности дозировки при данном методе и в Бозможности неполной всасываемости туберкулина. Но нас привлекала возможность применения больших доз без угрозы получения общих и очаговых реакщий.

Рамон исходил из идеи нейтрализации всякого рода токсинов при прицоснонении со слизистой носа, что было им блестяще доказано путем профилактической иммунизации капельным методом скарлатинозным, дифтерийным и другими токсинами.

Суюность действия тубернулина до сих пор неизвестна. Хотя тубсркулинотсрапия применяется не как метод прямой иммунизации, а как метод воздействия на аллергик, нам казалось, что к эндогазальному применению туберкулина можно подойти с точки зрения местной иммунизации по Безредка. Слизистая, и қожа обладают почти одними свойствами, а именно, когда вирусы проникают через слизистую или кожу, онределенная груипа клеток обладает известной автономностью. Эта групна к.леток, оставаясь связанной со всем организмом, способна заражаться и зашищаться от инфекции собственными силами, сообщая нммунитет всему организму.

Позже мы познакомились с сообщением об эндоназальном лечения порогико гинофиза несахарного диабета (А. Атабек, "Проблсмы эндокринологии", № 2, 1936 г.). Автор ірименял эндоназдлное внедение сухого пороцка задней доли гипофиза в случаях несахарного диабета и получил очень хороший терапевтический эффект; ряд других авторов тякже успешно проводил этот метод печения. Успех этого метода терапии и преимушесиво его перед подкожным, по мнению автора, зависит от путей оттока жрови н лимфы из слизистой носа, так как большое количество сосудов носа изливает свою кровь непосредственно в мозговье синусы. Для нас, в частности, важно то что лимфатическая система носовой полости представлена гу- 
стой сетью сосудов, сообщающихся $\mathrm{c}$ шейными лимфатическими железами, так как лимфатическая система несомненно играет известную роль в туберкулезном иммунитете.

Атабек, сраннивая результаты әндоназального и подкожного введения препаратов гилофиза, приходит к заключению, что дело не только в возможности введения больших доз, но и в отсутствии побочных явлений при эгом методе. Автор отмечает отсутствие раздражения и явлений воспаления слизистой носа, обьясняя это физиологической ролью носа и анатомическими особенностями строения его, так как слизистая носа является защитным барьером между вредным воздействием внешней среды н организмом.

На нашем материале мы получали интенсивные воспалительные реакции со стороны слизистой носа лишь у детей с высокой аллергией, дававших резкую реакциғ Пирке, в остальных же случаях незначительные катаральные явления легко поддавались $2 \%$ раствору шротаргола, которым мы, так сказать „блокировали слизистую.

Методика эндоназального применения туберкулина б́лла следующая; мы пользовались альттуберкулином К ха производства Hôchst'a; разведение делали в физиологическом растворе с добанлением $1 / \%$ карбол. кислоты. Туберкулин вводился н нос узкой пипеткой 1 раз в 2-3 дня гв зависимости от температурной и местной реацин), при полулежачем положении больного попеременно в правую и левую ноздрю. Несмотря на рекомендацио автора начинать с З-го разведения и сразу переходить на цельны туберкулин до $0,4-0,8$ чистого туберкулина, мы начинали с 3-г или 4-го развеления туберкулина, ирибавляли по одной капле и, доходя до 5 капель, переходили к 1 капле следуюшего разведения и так далсе до 5 калель чистого туберкулина.

Целалось это I) с целью растянуть лечение на более продолжительый срок, как это рекомендуется всеми, занимавшимися туберкулинотерапией, 2) во избежание местных вослалительных реакций. ІІри наличии воспалительной реакиия в промежутке между вкапываниями туберкулина мы применяли 24/о раствор протарлола или коларгола. Более 5 калель одного разведения мы не находили возможным вводить, так как жидкость, попадая в носоглотку, лавала неприятное оцуцение. В начале нашей работы мы производили определение туберкулинового титра по Эрландсену (реакция ІІирке-ІІетрушки 5 разведениями). Впоследствии, видя безвредность веедения через слизистую ниса й больших доз, мы прямо начинали с 4-го или 3-го разведетия, постепенно перехоля к большим дозам, останавлинаясь на 5 капля чистого туберкулина, последнюю дозу мы повторяли несколько раз. Через 2-3 недели повторьли лечение, начиная с 2-3-го разведения.

Если почему-либо приходилось надолго прерывать лечение, то по возобновлении его мы нанинали с более сильного разведения, чем то, на котором мы кончили до лерерыва. Титро- 
вать же внутрикожным способом, как это делается при подкожном методе туберкулинотерапии, здесь мы сочли ненужным, так как осторожное применение даже больших доз оказалось совершенно безвредным.

Эндоназальную туберкулинотералию мы начали на материале детского легочного и костного отделений Тубинститута. Параллельно работа проводилась по нашему предложеиню врачами детских отделений тубдиспансеров, д-рами Степановой и Талер, любезно предоставившими нам свой материал для общей обработки, за что мы приносим им сною благодарность.

Всего проведено в стационаре 30 и амбулаторно 43 случая. По диагнозам больные распределялись следующим образом:

Тбк периферических желез-25; кератиты, фликтены-13; тбк костей со свипами-5; экссудативные плевриты-6; хроннч. интерстициальные легочные процессы с участием плевры-5; фиброзные тбк шроцессы-2; хронич. лимфогематогенные рассеянные формы-2; 'юбк кожи-2; остальные 13 случаев, как незакониекные, в обработку не вошли.

Случаи с тбк желез мы подразделили на закрытые формы и со свицами. Закрытые железистые формы за редким исключением рассасывались, не подвергаясь размягчению, пакеты уменьшались в размере, оставляя впоследствии мелкие плотные железы, причем рубцовая ткань рассасыванио не подвергалась, што отмечено также в вышеупомянутой работе Ивановой.

При открытых железистых формах терапия данала быстрое размягчение, иногда вызывала появление новых, также размягчающихся желез. Но размягченные железы впоследствии подвергались рубцеванию, свици цокрывались свежими грануляциями. Процесс сопровождался иногда незначительным повышением температуры. В одном случае обширной скрофулодермы процесс медленно поддавался лечению; оцутительный результат получился при комбицрованном лечении с компрессами из рыбьего жнра.

Хорошие результаты цолучаются при лечении кератитов и фликтен, причем во всех случаях в начале лечения отмечалось обострение процесса. Некоторые случаи дали рецидив, но ири повторении курса лечения получались стойкие положительные результаты.

В нескольких словах следует остановиться на результатах лечения экссудатинных плевритов. Все амбулаторные случаи дали, по словам лечащих врачей, чрезвычайно быстрое рассасывание экссудата, что отмечается также придругих методах туберкулинотерапии. Џаблодавшнеся в нашем стационаре 3 случая свежего плеврита у детей одного возраста, дали слелующие результаты:

В одном-общирный экссудативый плеврит, леченный эндоназально туберкулином, рассосался совершенно в тецение двух недель, несмотря на то, что рсбенок принужден был оставаться в гипсовой кроватке (тбк спондилит); такое же быстрое рассасывание мы получнли у другого ребенка под влиянием комбинирова ног, применения салицилового ватрня и хлористого кальция. 
Быстрый успех лечения в данном случае мы объясняем тем; что ребенок попал к нам из крайне тяжелых жилищных условий (сырой, темный подвал). В третьем случае также свежего плеврита под влиянием салицилового натрия и хлористого калыция экссудат долг не рассасывался, несмотри на то, что ребенок находился н весьма благоприятных о́ытовых условиях.

Из двух случаев тбж кожи один представлял собой запущенную обширную волчанку кожи туловища и конечностей в сочетании c тбк костей. В данном сыучае мы отметили несомненный сдвиг в смысле улучшения старых очагов и прекращения появления новых. Общее состояние больного улучшилось, но на костный тбк процесс тераиия не оказала никакого влияния.

Кроме того, мы применли эндоназальное лечение в 5 слуџаях тбк костей со сницаии, иротекавщими крайне вяло, с целью вызнать некоторую реакцио организма, однако мы не получили никаких рсзультатов, возможно-потому, что в этих случая большое значение играла смешанная инфекщия.

В последием мы имели возможность убедитья, кокда одыа девоцка (Кл. М, 10 лет) подиерглась теленияо в состояния крайнего истощения после продолжительного пихорлдочно периода и о илього в иледенин уноя, причем можно было ожидаль, что мы ихеем дело с г нерахизацией процесса. Вгкрытие по-

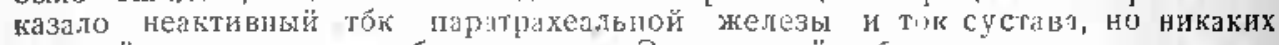
явлспий ген рализации тбк продесса́. Этот слуцай убедил нас в том, что и в состоянци резкото истопения әндопазальна туберкулиногерапия в применяемой нами дозировке безвредна.

Перейдем к описанию наиболее интересованшихнас легочных процессов.

Из них мы подвергли лечению часто встречающиеся в детском возрасте хронические интерстициальные процессы с участием плевры в период обострения. Таких случаев у нас было три, и мы вынесии убеждение, что туберкулинотерапия на течение әтих форм существенного влияния не имсла. Острые катаральные янления обынно скоро проходили, но через некоторое время под влиянием каких-либо факторов рецидивировали.

Несколько случаев инфильтраций в стадии затянувшегося об. ратного развия дали рассасывание инфильтрации с оставлением частичных индурационных изменениӗ.

В одном случае междолевого плеврита с тбк шейных желез мы полуцил явное обострение процесса, выразившееся в появлении свежей прикорненой инфильтрации в другом легком, впоследствии подвергнувшейся распаду (появлсние БК).

В одном случае хронического диссеминированного тбклегких мы отметили сдвиг в обпем состоянии ребенка, улущшение формулы крови, снижение субфебрилитета и катаральных явлений в легких без изменения ренггеновской картины их.

В одиом спучае фंиброзного тб́к процесса у девочки 6 лет из детдома нам удалось добиться скойкого исчезновения БК и катарлльных явлений. Через $2 \frac{1}{2}$ года посяе лечеиия в легких у ребенка кат:ральных яв.пений не оказалось.

Наконец, остановимся па последнем случас, клечению поторого мы шристувили с большими оғасениям $M$, Ш., $1+$ дет, поступияа виервые с распространенным очаговым правосторонним лроцессом, по поноду которого был на- 
ложен искусстиенный пневмоторякс, осложнившийся иневмоплевритом, после которого искусственный пневмоторакс продолжать не удалось.

Через год-њощный фиброз со смещелием органов средостеиия вправо, но с продолжающимся суғ ф брилитетом и БК в мокроте, высокой РОЭ и отклонением формулы влево, С.льва рентгеноскопических видимых изменений не окдзалось, по кииически отмечался жесткий характер дыхания. В это время мы и цриступили к эндоназальной туберкулинотерапии с одной капли 4-го разведения. Незначиельные повышения тємпсратуры мы внатале отнесли за сует вслышек тропической млярии, но все же решили девопку лодвергнуть рентгсногряфии, иричем слеяа нашли мелкоочаговую диссемизацию в среднем легочном поле и подозренис на каверну под вторым ребром.

Церез полтора месяца в среднем поле-тяжистость, канерны не видно, но через $1 \frac{1}{2}$ года девочка полибла от спонтанного пневмоторакса, вследствие прорыва каверны слсва́ в плевру.

Заканчивая настоящее сообиение, мы бы хотели сказать несколько слов о реакщи на эндоназаљьную туберкулинотерапию.

В половине случаев через несколько часов повышалась температура не выше 37,2 , обпее ссстояние не нарушалось. В двух случаях мы толущй свежие инфильтрация и в одном-вспышку iролесса на второй стороне. РОЭ и формула крови либо водсе не изменялись, либо мы видели незнацительное замедление РОЭ и сдвиг вправо формуль крови, но почти всюду отмечалось увелицение количества лимфоцитов.

Приступая к оцение полученных нами результатов, мы считаем возможным сделать следугщее заклочение: 1) эндоназальное применение туберкулицогерапии является вполне әффекіивным при тбк желез и при других скрофулезных проявлениях ( тбк кератиты, фликтены, spina ventosa, скрофулодерма), тбккожи, свежие эксудативные плевриты.

2) Хронические интерстициальные прощессы с участием плевры не поддагося этому методу гечения.

3) Из других фори леточного тбк у детей некоторый эффект дают фиброзные й хронические диссенинированные процессы. 
Из Казанского ннститута энидемиологии и микробиологии ТНКЗ (наупный руководитель проф. Р. Р. Гельтцер).

\section{【 вопросу о влиянии активной иммуннзации на носительство дифтерийных палочек.}

\section{С. М. Вяселева.}

Если в активной иммунзаци против дифтерии мы не имели елце до сих пор средства, гарантируючего во всех 100\% от заболевания, то во всяком случае это средство оправдывает возлагаемые на него надежды. Научная мғсль не останавливается на достигнутом, а ищет новых путей для увелиния эффективности прививоки упролцскя метода иммунизации. Гро. мадный материал по данным отечественных и иностранных авторов нлиостирует результаты противодифтерийной иммунизации сравнением процента заболеваемости и смертности от дифтерии средн привитых и непривитых групп детского населения.

Однако, по вопросу о влияник противодифтеридйы прививок на бациллоношение дифтерии и о ғазнице в ногительстве иммунного и неиммунного организма мы в доступной нам литературе нашли очень немногое.

Так, в 1926 году Орлов в отчете Подольской райониой лаборотории о противодифтерийной работе указывает, что проведенгая им в большом масштабе шикизация органзованнық дстей, а также обследованис на бациллоношение наметили обратную занисиость между положитепьой релкцей [Шика и распространением посктельства В другой своей работе, разбирающей релкци Целгера, Орлов подтверндает свок набыюдения, такие отмеха, тто степень иммунщзации детей пропорциональи степсли носительства дифтернйіой и псевдодифтерийной палочки.

В 1924 году поянилсь уже 2 более обстоятельные работы этого автора совместио с другими. Одна нз ыих (Орлова н ('тавровской) приводит результаты облледовани 3-х закрытых детских угрежденпй пи бацилоношение днфтерин, с учетом реации ШІка и общего спниарного состояния В этих уюрежденит значительный процент детей был шикотрицательным, благодаря ранее проведенной нммуизаци и частично благодаря споптапной иммунизации. Авторы дополюительно произвели прививки апатоксином дстям, до того пе иривитым, и, таким образом, иммуниал прослойка оказалась чрезвычайно большой, дойдя в летском костно-туберкулезном салиторин до $9 \% / n$. B результале этого бацилдоноценне среди дстского коллектив знатительно снизиось, а такае изменился харавтср поснтельслва п сторону падения вџрулснтного носительства. На этом основываелса вывод авторов, что активна иммунизация против дифтерия является одним нз методов ликвидаци лифтерийного балиллоношения.

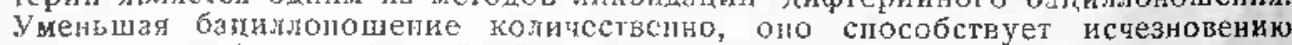
вирулентых форм дифтерийной палочки.

В пругой работе (Орлова, Ставровской и Грауи) приводится данные обследования детей млальего возраста дома младенца, где была вспышка дифтерии. На реакцю Шика все дети дома млалснца реагировали отрищательно; поэтому как показатсль иммунитета авторы взяли законченпую активную иммунизацию и сюда же к группе иммуныв отнесли дстей до 3-мссячкого возраста. Обследование на бациллоношение дазо очень высокие цифры, хотя среди носителей преобладали носители авирулентных форм. 3 этой же работе указывается на то, что заболенания и носительство (вирулентное и авирулентное) распространяются преимущественно среди детей не иммунизировапных. Кроме гого, авторы предполагают, что вирулентная дифтерийная палочка, попадая в иммунный организм, теряет или понижает свою вирулентность. Это предлоложенне 
ясходит из наблюдений над сиучаями, когда дети с законченной имнунизацией через заведомый контакт с носителяии вирулентных дифтерийных палочек также становятся носилелями, но уже авирулентных палочек.

Рошковская и Коробицына, разбирая динамику распространения дифгерийного бацилиношения па тримере ленинградского дома малютки, отягощенного бұцизлокошением, приходят $к$ апалогичным даныым В грудном отделении этого учреждения, где виачале огсутствоваяа лгрослойка активно иммунизированынх, наличие вирулентных итаммов среди носителей сосавляло $72^{3} \%$. Благодаря дальнейшей иммуниз'ции детей этого отделения процент вирулент ного носительства понижаегс, дойдя до 16,6\%. В малюточном отдении, при наличии 10 , јо иммунизированных, не оказалось ни одного посителя вирулентных птаммов. В грудиом отделении наблюдался наиолее широкий охват бациллоносительством детей по сравнению слругими отлелениями дома младенца.

Фигатнер, об́следовавший школьников l и тельство цирулентых штаммов дифтерии обнаружено лишь у детей, не подвергавшихся еще иммунизация. Герцева и Зиновьева на основании обследования 797 детей, относиғельно которых имелись сведення о шротинодифтерийных прививках, нашин, что на 503 чел. привитых приходилось 5 , $(11,3 / 0)$ здоровых носителей; на ¿و4 непривитых - $0(10,20 / 0)$ носителей.

Настоящая работа имеет целью излокить имеющийся материал по обследованию на бациллоношение дифтерии детского организованного даселения за 1936 год. Обследования произнодились исключительно по эпидемическим показаниям, т. е. при наличии случая заболевания в детском коллективе. Нами разработаны данные, касающиеся об́лледования школьников, детей детских садов и различных интернатов (детский дом, дом охраны мат. млад., Институт глухонемых и проч.). Группа обследованных детей, посещающих ясли, нами сознательно не обработана, взнду слишком малого охвата этой групाы шротиводифгерийпыми прививками, что не давало возможности выделить в ней достаточную прослойку из привитых. Сведения о прививках получались от обслуживающих детские учреждения врачей с указанием, когда прививался ребенок и какое получил колимество прививок. В разработанный материал вошли только те привитые, иммунизация которых была 3-кратно или 2-кратно (по новой инструкции) выполнена не раньше, как 2 месяца назад до выявления бациллоносительства, Всего нами обследовано 3046 человек, из них 1073 привитых и 1973 челов. непривитых. Разрабатывая материал, мы старались обе разбираемые группы (привитых и непривитых детей) взять в наиболее однородных условиях, қак в смысле возраста, посещйемых учреждений, так м в смисле обцей эпидемиологической ситуации. IІо табл. 1 можно проследить распределение обследованных по детским учреждениям. Больше всего обследовано школьников-1445 чел., затем дошкольников-947 чел. и, наконец, меньше всего детей закрытых учрсждений, интернатов--654 человека.

Разбирая суммарный средний процент бацилоношения среди привитых и непривитых $(12,9 \%)$, мы видим, घто он стоит довольно близко к литературным данным других авторов. Сравнивать данные по бащиллоноцению вообще весьма затруднительно, так как цолучаются резкие колебания процента носительства в ту и другую сторону, зависящие как от разницы общего числа обследованных, так и от контингента носителей, 
Таблици і.

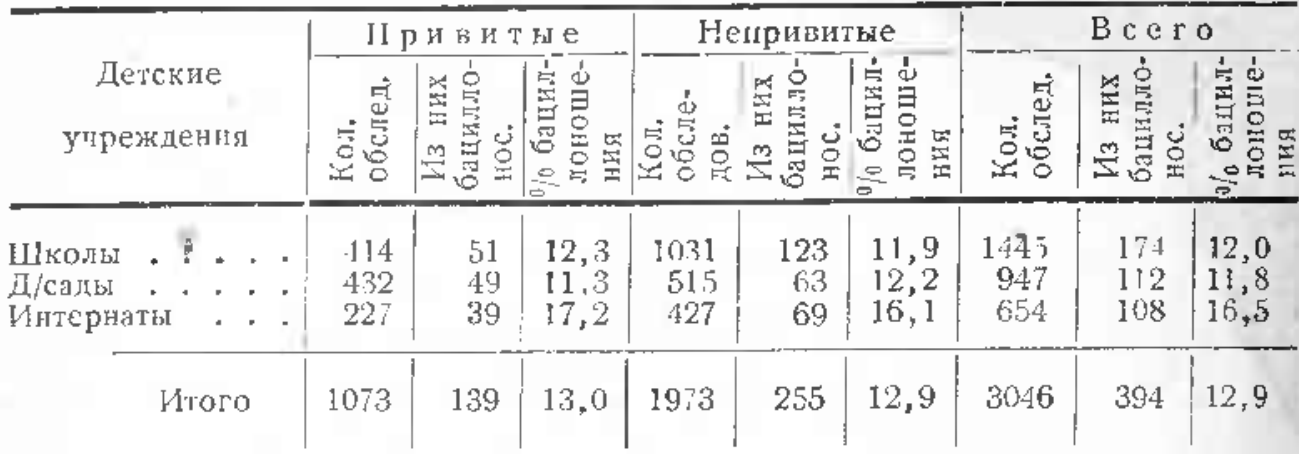

т. е. были іи обследованные лица в контанте с болыными или не были.

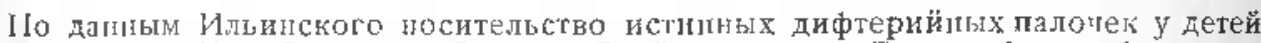
составило 12,3\%. Башенин, Бнргср, Брийловская и 'Трахтенберг; обследовав в Москве 14434 чет., обнаружили 12,6\% дифлерийных носите:ей. Јепехнн, Морозов н Иоселевия считают, что количество здоровых бациллоносителей по давпым Киева колебанось за 1927-31 гг, в пределах от 2,7 до 12,70i .

По даным Данилевича (Ленинград), обший процсат носнтелей среди детей равен 8,2, а срели детей до 7 лет-11\% Раинек, проводившй обследование в школах Висбадена, юашеп, что в классах, давших заболевания, тисло восиелей доходиіо до $15 \%$. Другие авторы, производившие обследовалия среди детей, контакта пе имевыни, конетно, дают значительно менцшие цифры носительства. Вообще, по различным данным процелт лоситсльства варьирует от 0,2 до 50 и выше.

Гри сопоставлении घастоты бациллоносительства среди иммунизированых и неиммунизированых детей нельзи отметить какой-либо разницы. Из табл. I видно, что та и лругая групіа дают почти одни и те же цифры бациллоношения: привитые$13,0 \%$, непривитье- $12,9 \%$.

Относительно длительности бациллоношения разногласий в литературе меньше; в больиинстве случаев очищение от бацля происходит в течение первых 15 дней. При разборе сроков носигельства у привнтых и непривитых по нашим материалам можно видеть знацительную разницу (табл. 2). В то времл как бациллоносителей $\mathrm{c}$ длительностьо бациллоношения до 15 дней среди привитых детей имеется $89,7 \%$, среди нелривитых-

Таблица 2 .

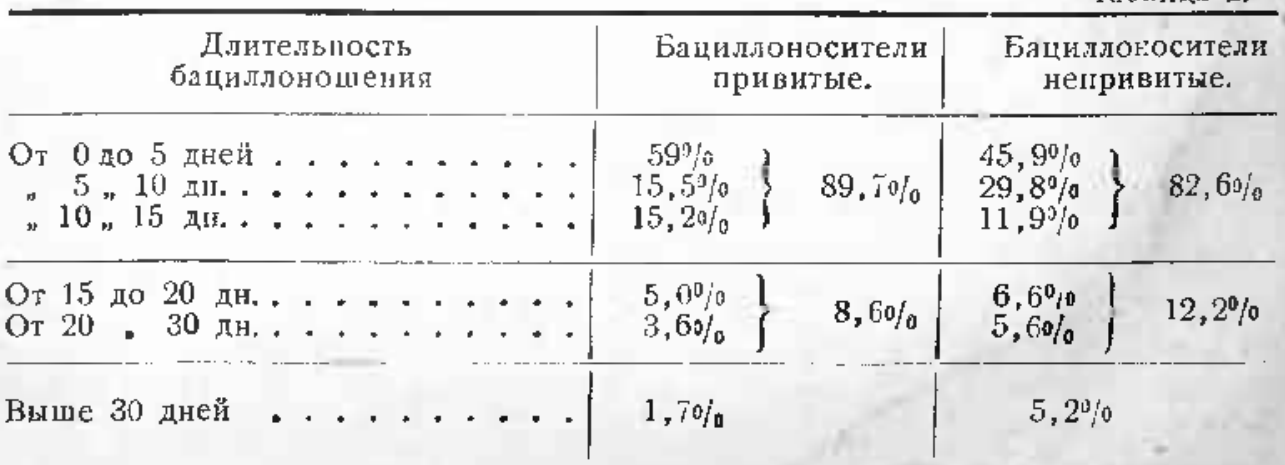


$82,6 \%$. Затем, группа гіривитых с длительностьо бациллоношения от 15 до 30 дней равна 8,6, непривитых-12,2\%. Наконец, бациллоносителей с периодом носительства выше одного месяца среди привитых отмечается $1,7 \%$, тогда как среди непривитых-в 3 раза больше, т. е. 5,2\%. Гакнм образом, эти данные указывают на то, пто среди иммунных детей зиачительно меныше длительных бациллоносителей, чем среди неимунных.

Орлов и Ставровская считают, что большая длительность носитеиьства имеется у тех лид, где выделялись вирунентные культуры и, наоборот, у „пасситных“ носителей (кратковременных) преоблалают авирулентіые культуры.

По даным Клауберга, который прокзвел обслепование в Берлине, явствует, что среди носителей дифтерийной далочки тил "grnvis " встречаетея в 3 раза реже, пем у больных, и при этон длительность при ,

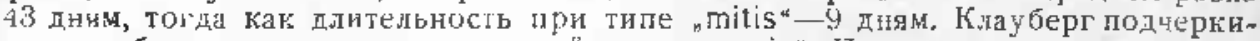
нает особенную оласность носителей тија "gravis". Iloэтому важно учест, что среди иммунизированных детей затяжных бацилловосителей значительно мекьше, ңежели среди неиммунизированных.

Вирулентность выделснных от носителсй штаммов днфтерийной культуры мы лоцвергии проверке на морских свинках путем внутрикомной пробы, частьюписгой культурой по методу Игльтоп и Бакстера и частью-смешаниов̈ по Хавенс и Повелла. Всего проверено 211 культур.

Оказалось, что процент вирулентных штаммов среди бацил лоносителей привитых равен 18,3, авирулентных-81,7, тогда как среди непрнвитых вирулентных штаммов $32,5 \%$ и авирулентных 67,7\%. Отсіода приходится спелать заключение, что дифтерийная палочка, находясь в носу или зеве активно иммунизированного бациллоносителя, претерпевает какие-то изменения биопогических свойств в сторону образования авирулентнвх форм. K такому же выноду в своей работе приходят Орлов, Ставровская и Браун, как уже отмечалось выше. Минервин, основываясь на экспериментальных даныых, касағыцхся изменений дифтерийпого микроба при прохождении через иммунный оргашизм, также указывает на этот факт. Он предварительно иммунизировал свинок дифтерийным анатоксином, испытывал их на присутствие иммуниета и затем вводил им внутритестикулярно эмульсию дифтерийной культуры. После такого пассирования выделялась культура, резко и стойко изменивцая свои бионогические, серологичсские и вирулентные снойства. Эти изменения щли в сторону приближения к дифтернеподобным штаммам.

Волрос об элидемиологическом значении того или иного бациллоносителя и степени его активности нуждается в более углубленной разработке. Количественное определение инфекта, а не только выяснение качестненной его сторонь, как это рекомендуют Гартох, Данилевич, Иоффе и др., изучение типажа дифтерийных бацилл у носителей,-все это должно быть применено для дифференциального подхода к привитым и непривитым носителям. Но әто будет дальнейшей задачей; на основании же имеющихся у нас материалов позволим ссбе сделать следующие выводы:

1. По нашим данным цастота бациллоносительства среди детей, активно иммунизированных против дифтерин и неиммунизированных, в среднем стоит на одних и тех же цифрах. 
2. Длительность бациллоносительства у иммунизированных короче, чем у ненммунизированных. Среди последних значительно больше детей со сроком носктельства, превышающим 15 дней и даже 1 месяц.

3. Из произведенной проверки вирулентности 211 дифтерийных культур следует, что привитые бациллоносители только в $18,3 \%$ ялляются носителями вирулентных штаммов, а в 81,7\%авирулентных. І зосители же не гривитые дают гораздо более высокне цифрь вирулентных штаммов, выраказощиеся в $32,5 \%$, и авирулентных-в $67,5 \%$.

Jumenamypa. 1. Башенин, Биргер, Бралловская и Трахтенберг, Гигиена и эпид., 요 12, 1927, - 2. Гартох, Казарновская и Беньяш, Микроб. ж., т. ХІІ, в. !, 1931.- 3. Гартох и Муратова, там же т. XII, вып, JI-III, 1931.-4. Гердева и Зиновтева, Труды Куйоышевского гос. мед. нн-та, сбор. 4, 1937.-5. Данилевия, "Проблсыы дифгерии",-6. Данилсвич, Сов, вр. газ, № 17, 19 5. - 7. Қльинский, Ж. ранн. дет. возр., т, Xl, № $11-12,19$ 1.-8. Иоффе, Доброхотова и Хрущева,

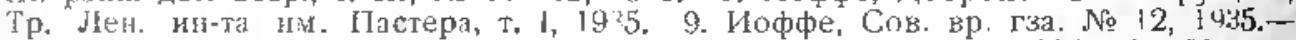
10. Леясхи, Морозов, Иоселсви', Ж эпнл. и микроб., № 3, 1934.-11. Минервин, Ж. зкспер. биол. и мед., т. ХIV, 38 серия, Б. 19.20.-12. Ортов, Ж. микр., пат., илф. 6-ней, т. IV, ь, 4, 192 .-13. Орлов и Ставровская, Ж. эпид. и мик" роб., 추 4, 193 t.- 14. Орлов, Моск. мед. ж., № 3, 192.-10. Орлов, Станровская ч Браун, Ж. эпнд. н микроб, № 4, 1934.-16. Рошковская и Коробидына, Про-

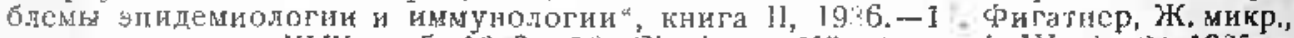
эпид.. иммун, т. XVII, в. 5, 19 6,-18. Clituberg, Nünch. med. Woch. 24, 1935.19. Reineck.-Реф. по Анн. Мечн. ин-та, т. I, в. I, 1935.

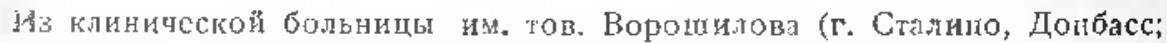
тлавврач Н. И. Миронович).

\section{K клинике retinitis albuminurica gravidarum.}

\section{ผ. М. Золотарева и Н. И. Медведев.}

Ослокнения со сторонь глаз при беременности довольно многорбразны. Встрецатся как сравнительно безопасные осложнениярасширепие лимфатических сосудов коньюнктивы, истерические расстроиства двигательных мышц, гемералопия беременных и др., так и серьезные страдания, подчас служацие грозными признаками общего тяжелого заболевания.

К последним относится и пеuro-retinitis albuminurica gravidarum. K счасгью r, а. g. встречается не так часто. Шиотщ при массовом обследовании 8400 беременных обнаружил его в 35 случаях, в то время как токсикозом беремепных страдало 680 из ело больных. IIо данным Силекса на 3000 беременных приходится один случай г. а. g. Адам в 1911 году описал 92 случая эклампсии, изних в 2 случаях был г. а. g., между тем Эш (1910г.) нз 496 случаев видел г. а. g. один раз. По Шиотцу среди женщин, страдающих эклампсией, у одной из шести набгюдается ретинит Боссе среди 300 рожениц наблюдал 4 случая, а Ларибуазе на $122 ! 6-5$ случаев и т. д.

Несмотря на то, что приведенныс материалы неоднородны 
(часть авторов проводила поголовное обследование беременных, а часть только экламптицек), они дозволяют все же вывести заключение, что т. а. g. наблюдается не часто. Статистические данные различных авторов показывают, что приблизительно $2^{0} /$ беременын страдают осложнениями со стороны почек, но среди них сопутствующцие заболсвания сетџатки очень редки

Альбуминурический ретинит беременных в статистике общего альбуминурического ретинита занимает также относительно скромное месло. Так, Тутсуи на 110 случаев альбуминурическоло ретинита отмечает 8 случаев альбуминурического ретинита беременных.

R. a. g. пстречается преимуцественно у первородяцих, чапе во второй половине беременности, развиваясь медленно в течение недель, а иногда и месяцев. Бюрнье, разбирая 168 случаез r. a, g. по срокам беременности, представил их в следующих цифрах: до 6 месяцев 35 случаев $(21 \%)$ от 6 до 7 мес. 64 слуг. $\left(38^{\circ} / 0\right)$; от 8 до 9 мес. 56 случ. $\left(33^{\%} / 0\right)$ и после родов $8 \%$.

1олавляющсе большинство случаев r. а.g. (79\%) встреधается, следоватељьн, во второй половине беременности. В начале беременности наблюдаются явления интоксикации в виде рвоть, отсутствия аппелита, общего недомогания. C развитием г. a. g. больные отмечало прогрессинное падение зрения, туман, мер цание перед глазами. Затем появляются: головная боль, отеки, изиенения мочи и повышение кровяного давления.

Іри объективном исследовании обнаруживается: зичительиос понижение остроты зрения, иногда-шадение его до светоопущения; зрачки расширены, реакцин на свет ослаблена. При офталмоскопии часто отмечается гиперемия соска зрительного нерва, смытость его границ, расширение сосудов. В области maculae luteae, а также по периферии появляются характерные бляшки, часто образующие в области желтого пятна так называемую звезду. R. a. g. может осложняться часто кровоизлияниями в сетцатку, огском се (из-за повышенного давления и аутоинтоксикации), отслойкой сетчатки, иногда последующей атрофией зрительных нервов.

Изменения моци (значительное количество белка, эритроциты как свежие, так и вышелоченные, цилиндры) в сочетании с повыпенным кровяным давлением и увеличением границ сердца характерны для нефропатии беременных. Так, Вайсыэн находи. но всех случаях нейроретинита беременных кровяное давление выше $180 \mathrm{~mm} \mathrm{Hg.} \mathrm{Обычно} \mathrm{нет} \mathrm{воспалительных} \mathrm{изменений} \mathrm{со}$ стороны клубочков, а лишь дегенеративные; поэтому можно цредставить себс это заболевание как сочетание нефроза с ги. пертонией. По Грєнуву, Силексу чаще всего г. а. g. сопровождает почку беременных. Однако Тихомиров отмечает, что из работы Силексд нс видно, было ли обращено внимание ири последующих осмотрах на общее клиническое обследование, которое одно и могло показать, была ли то почка беременных или хронический нефрит. Есть указания и на острый нефрит, как этиологи धеский фактор, но острый нефрит у беременных встречается редко. 
На основанин литерлтурных данных следуег ситать, что чаше в основе ныеющегося г. а. g. Лекиү хронический нефрит, обострнвщийся из-за наслоившейся интоксикации бсрсмелных. Исследованиями Вильфа, Џадде, Шиотца

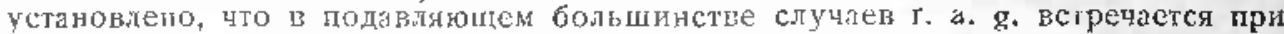
хроническом нефрнте, реже это заболевилие двляется следствием нефропатии бореметных. Вольф и Цалле в 106 с-учаях беременлосии, остожненяой заболе-

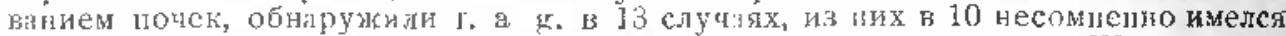
хронический нефриг. Вполне демонстратинными жнияются даніше Шиотца, где из 40 больных г. а. g. 33 подверглись длителяному наблюлению, и у 27 больпых бцл обиружіл хроническнй нефрнт. Закс из 210 слугев поражения

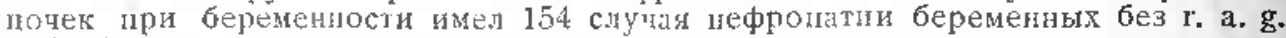
15 бо больных с хроническим нефритом.

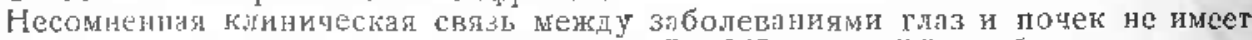

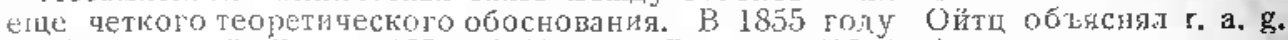

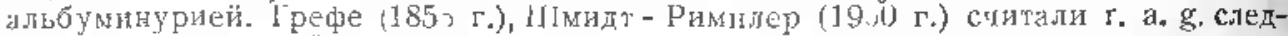
ствисм хронимекой уремик.

Иного миения прндерживатся Теодор, Mихсль, Ветс, Еведкий. Оги саитан заболевание почск и сетчати самостоятслынын, паралысльн идущими заболеваниями, с избирательным поражелием сосулистой систены. Отсюда

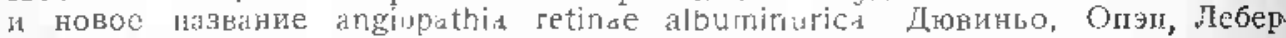

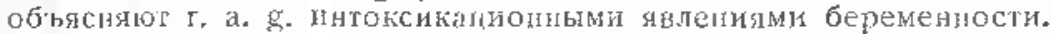

Џымер и цыненыейстер полакют, тло продукты обмена в плценте (syncytotoxin) токсичны длля почек н сстуатки.

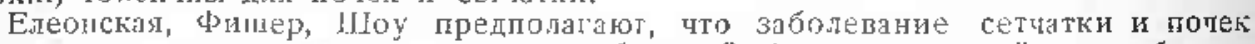
развивается самостоятельно из-за ослабленной функциональлой способлости почек и лействия ядовитых веществ.

Мијлиус говорит о слазмс сосудов сетчатки без поражения стенок их.

Ни одна из вынеперечислениы теорий патогенеза т. а. g. не может претендовать на закончснность и ясность; патогенез заболевания, относительная редкость его даже при хроническом нефрите остағося до сих пор проблемой, пе нашедшей еще своего полного разрсшения.

Патолололдатомические изменепия при r, а. g. локализуются как в нервпой, так и в сосудистой тканн.

Іренув различает четыре вида поражений:

1. Отек сентаки. 2. Жировос порсрождение нервной тканн. 3. Варикозные утолщения на нервиых волокнах. 4, Изменския в сосудах.

Отек сстуаки наблюдаеся обынно на участке вокруг соска, в этом месте сетчатка представляется муднй, выстоит выеред, и сосуды производят впедатление темных полосок, как при обычных отсіойках сетлатки.

Жировое перерождение особенно поражает оби споя идер и наружный рети. кулярный слой.

Типиная ильбуминурическал звезда по исспслованиям Димиера представляет собой скоплене кучек клеток с жировыми з:рнышками в радиарно-расходнщихся волокиах паружного волокиисто слов lенле, р сполагаясь в желюм пятне между наружным рстнкуляным и наружным ядерным слояни.

„Как раз это место, лежышее лаледо от калилярных сосудов ретины и хориоидеи, наио̆оне подвержено перерождению“ гопорит Шмидт-Рмиплер.

Малешьке белые пятна, покрынағшие сосуды сегнтки, доджны быть отнесены к жировому перерождению полдерживающей ткани, а большие глубже лежащие-к скопленю жировых зернышек в наружыых слоях сетчатки.

По Леберу жировые киетки-это клетки странствующего пигмснтиого эпнтелия, нагруленные жировнмн зернами, полученными из серо-фнбрназиого эксудата. і1осроение жира идет в с́мой клетке. При воспалении лочек Лаубер и Адамюк в 1909 г. находили в сетчатке лилоиды, аналогичные имеющимся при этом в почках.

Кровсносные сосуды лодвергаются склеротическому, гналнновому, реже амихондному перерождению, неогда с закупоркой просвета. Это особенно отра- 
жается на сетчатке, т. к, сосуды госледних являются конечными. Исследовлнне сгенки сосудов показало вослалительные изменения и перерождения их (Яма. гуши, Михель и др.).

Часть авторов (Теодор, Ямагуши, Копен) и др. считает заболсвзние сосудов причиюой поражегкя сегчтки. Силекс, Опэн, Рощон, Дювиньо, Лаубер и др. раслепиваюг измсления в сосудах как вторичные, вслсдствие интоксикацин.

По мнению Гренува, заболевание почек ведет к нарушению цнркуляции крови я замеллени кровотока; отсюда-венозный застой, обусловливающий вторицıые изменения.

Отек, воспаление зрительпого перва злканиваюся у Iaminae cribrosıe.

Ірогноз при г. а. g. зависит от времени проявления болезни, характера основного почечного заболевания и, следовательно, от того, как скоро после обнаружения т. а. g. разрешена или устранена будет беременность (самопроизвольные роди или оперативное вмешательство).

При поцке берсменцых или остром нефрите prognosis quo ad vitam благоприятиее, чем при хроническом нефрите, осложненном г. а. g, когда прогноз оказывается очень печальным.

Что касается prognosis quo ad visam, то после родов в тех случаях, где была нефропатия беременых, острота зрения может восстановиться полностью, с постепенным исчезновением патолюгических лвлений на глазном дне. Все это касается тех случаењ, где не было осложнений г. а. g. (воспалегия зрительного нсрва, отслойки сетчатки, кровоизлияний и др.), которые значительно усложияют дальнсйшее течение процесса. При хроническом нефрите изменения стойкие, мало обратиыые.

Лечсбные мероіриятия шри альбуминурическом ретините беременных представляют далеко не легкуг задачу, так как приходится решать вогрос о двух жизнях. В этом одна из серьезных трудностей, дакс если пред нами нефропатия беременных, как основная причина страдания. Если же дело касается старого, хроническоо процесса, обострившегося под влиянием токсикоза, положение оказывается особенно ссрьезиым.

Если r. а. g. проявляется в перпые песяцы беременности, то последня должна быть немедленно прервана. Значительно чаце, однако, г. а. g обнаруживается в последине недели или месяци беременности. В этих случаях необходим тшательный индивидуальный подход, но жизнь и здоровье матери осталотя опрецеляющими при выборе лечебных мероприятий. Шиотц рекомендует прерьвать беременность даже $\mathbf{c}$ последующей стерилизацией, если в результате наблюдения будут установлены признаки хронического нефрита, По этому вопросу нет полного едннодушия во взгиядах авторов. Одни (Силекс, Махамара, Кэббертсон и др.) настаинаю на прерывании беременности цезависимо от срока ее, другие жк (Аксенфельд, Снелл, Макко) рекомен дуют прерывать беременность только в первые шесть месяцев или до срока жизнеспособности плода, после этого временилишь в исключительных случаях. Мы полагаем, ито должны бытъ определенные данныс, говорящие о безопасности или относительной безопасности выжиданин, которые оправдывали бы отказ лечацего врача от срочного прерывания беременности. 
Такие гарантируюпце здоровье матери данные при этой грозной болезни крайне редки. Более того, женцина, имевшая беременность, осложнившуюся альбуминурическим ретинитом, должна быть категорически предупреждена об угрозе рецидива при новой беременност. Известнн случаи, когла женщины, оправивниеся от пгефропатии н альбуминурического ретинита, в дальнейшем совершенно благополучно переносили беременность и роды; однако наряду с этим мы наблюдаем женщин, которые при иовторной беременности слепнут и гибнут. Можно считать, что сюда относятся больные с обострением хронических почечных страдаяий, а не с почкои́ беременных. Однако и точно установленный диагноз нефропатии беременных не решает поставленной проблемы. Не исключена возможность, что повторная беременность у лица, перенесшего ранее нефропатию, вызовет тяжелый процесс н дискредитированных почках.

За последние два с половиной года нам пришлось наблюдать 5 больных с альбуминурическим ретинитом беременных; большая часть из них продолжаея оставаться под наблюдениеи и в настоящее время.

1. Бољьная Б., 27 дет, поступила в зкушерскую клинику ДаМИ 16/X] 1934 г. с 9-месячлон̆ берсмснностью и цастьми схватками. Беременность вторихная. І1ервая беременность и роды нормальные. Жалобы на головныс боли и плохое зрение на протяжении последних двух недель. Больная резко пастозна. Кровя-

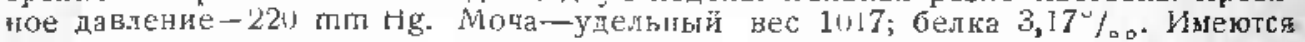
едииичне эритродиты и гиалиновые цилиндрк.

$16 / \mathrm{XI}$ родниа жнвого ребенка; после родов кровяное давление $-215 \mathrm{~mm} \mathrm{Hg.}$

19/1X исследоване окулист: Vis o. u. = (1,]. В области желтого пятна альбуминурические о́ляшки, кровоизлияния. Диагноз: Retinitis albuminurica gravidaruт. Сделана венепункция, вылущено 30 см³ крови.

За өремя преб́вання в клинике количество белка в моче уменьшилось до $1,85 \%$, удельный вес поднялся до $142 \%$, ковяне давледие держалось на высоких цифр х $-170-18 \%$

18/XI залючение терансвт: нефропатия беременных. Больная далее находилась под набиюдением глазного и терапевтического кабинетов поликлиники. До $21 / 1195$ г. зрегие поднялось до единицы, альбуминурические звезды исчезли, сосок в пределах пормы. Кровяное давление $120-10, \mathrm{~m}$. m $\mathrm{Hg}$. В моге шезначительиое количество бенка $-1,25^{\circ} /$ пе.

Больна была осмотрена ровно иерез год. Глазное дио-џорма. Острола зрения в обоих глазах $=1,0$. Кровяное давленис $120 \cdots 100 \mathrm{~mm} \mathrm{Hg.} \mathrm{В} \mathrm{мочс-следы.}$ белка.

В данном случае r. а. g., несомненно, зависел от нефропатии беременных. За это говорит быстрое и полное восстановление функция почек и глаз, а также іришедшее к норме кровяное давление.

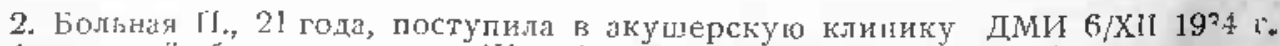
с 4-месяной беременностю. Жалобы паловокружение, ослаблепие зрения. рвоты и частые носовыс кровотеңспия. Тажое состоянне лродолжастя в тече-

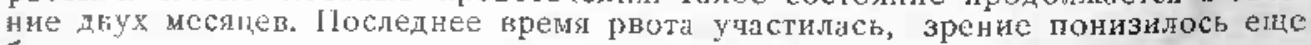
больше.

6/Xil обилне носовое кровотеченис; доствлена с тамполом в носу. Беременность вторая, тервые роды нормальные. Со стороны легких и сердца огқыонений от пормы нет. Кровяное данление-185 $\mathrm{mm} \mathrm{Hg.} \mathrm{Днагноз-лреәк-}$ лямпкия.

9/Xil ocмотр окуииста: Vis oc. $d .=0,02$; Vis oc. s. $=0,02.3$ рачки максимально рлсшнрены, слабо реагируют на свет. Колтуры сосков зрительного нерва ие- 
ясны, сосок слегка гиперемирован, альбуминурические звезды в maculae Juteae обоих гдаз, большое количество бляшек по периферии. Диагноз - retinitis albuminurica gravidarum. Дано заклюqение о необходимости прерывання беременности.

11/Х:I после введения мстрейринтера роднлся мацерированный плод.

$17 / \mathrm{Xll}$ Vis, uc. utr.= $=1,05 ;$ cocok лочти нормальной окраски, начннает контурироваться немного ясней, бляшки умсиьшились в количесле. Моча-удельный вес 1110,6 блка-0,4\%. Кровяное давление $14 \mathrm{~J}-110 \mathrm{~mm} \mathrm{Hg.}$

$26 / \mathrm{X}$ il Vis. oc. utr.= $(1,1 ;$ соски хорошо контз рируются, небольшая звезда в области желтого пятна, по пернферии остатки блянек. Через нескольно дней болъная по собсгвенному жсланию выпнсалась.

$20 / \mathrm{XI} 1935$ г., т. с поцти через год, больная снова поступила в акушерскую клинику с беремелностью в три с половиной месяца. По сповам больной, до этой беременности пувствонала себя хорошо, видела хорошо. Последиие дни появилась тошнота, рвота, головные боли. Больная полюостью потеряла зрение в левом глазу, в правом же зрение знацительно понизилось.

Исследование ожулиста: Vis, o. $\mathrm{d}=(1,4$, Vis. o. $\mathrm{s}=\mathrm{U}$. Альбуминуридески тинит обонх глаз. Гррелложено прерывание беременности. Ухудшение зрения продолжадось и, несмотря на аборт, больная потеряла зрение и в правоз глазу. Она была переведска в терапев'ическую клинику, где находилась с 2 „ХХ 1935 г. по 11/IV 1936 т. Со стороны общего status'a при поступлении отмепается только систолический шум на верхушке и акцент на втором тоне. Кровяное дивление $209 / 160 \mathrm{~mm}$ hig Мома: удельный вес 10,9 , белка $1,85^{\%} / 00$ эризроцитов $1-2$ в поле зрения, едишицные гиалиновые цилиндры.

23/XI. Cо стороны глаз: боли при движения глаз и при отдавливании глазпого яблока кзади (ретробупьбарный неврит интоксикационного происхождения). Соски зрительных нервов бледны, особенно справа, сосуды сужены. В области жеытого пятна много альбуминуридеских бляшек с отделыным кровоизлияними. Все время пребывания в клинике кровяное давление держится на высоких цифрах. Максимальное $200-215 \mathrm{~mm} \mathrm{Hg}$. В моче-белок, кровь, цилиндры, низкий удельный вес. Диагноз: хронический нефрит, злокачествен๒ая гиј:ртония, альбуминуричсский ретинит.

Со стороны глаз - полная атрофия соска зрительного нерва, громадиых размеров альбумннурические звезды, кровоизлияния.

$11 / \mathrm{V} 196$ года прн вв.нения уремин-смерть.

При вскрытии (протокол № 7ь9): резкая анемия всех органов брюшной, грудной и ферепной полости. Жировая дегенерация мыццы сердца, амилой сеяезенки, нефрозо-нефрит.

В этом случае повторная беременность дала рецидив альбуминурического ретинита. Можно думать, что больная ранее страдала хроническим нефритом. Беременность ускорила печальный исход заболевания. Альбуминурический ретинит осложнился. атрофией зрительных нервов.

3. Больная В., 20 лет, поступила $12 / 1$ 1935 г. в родилынй дом Донецжого института охматдета с шестимссяннй берсменностью. Последнис три недели заметила облие олеки, понижение зрения, судорожные подергивания вердней и нижней конецности. Жалобы на сильную головную боль. В анамнезе заболееание почек.

Iри осиотре обиаружены большие отеки, тоны сердца акиенунрованы, пульс папряжен, 104 удара в минуту. Кровяное давление $167 \mathrm{~mm} \mathrm{Hg,} \mathrm{в} \mathrm{моче} 3.7 \%$ 。 белка, единичные гиалиновыс цилиндры.

$12 f$ осмотр окулиста: Vis, o. u.- - слету пальцев у лица. Глазыое дыю в обонх глазах усеяло эксудативныни очагами, границы сисков зрительныз нервов сглажены, имеются свежие кровоизлияния. Диагноз: альбуминурический ретипит беременных. Џоказано прсрывание беремениости. В этот де денъ было проделано кесарево сечение под общия эфирным наркозом.

$14 / 1$ больная возбуждена, речь не нмеет смысла, выпадают отдельлые споги. Ригидность иижиих консчностей. Нешронзвольное мочеиспускание, даралич нижних конечностей.

2!/I Vis. oc. utr.= стету пальцев у лица, по всему глазному дну-зксудатив- 
рые участки й остатки кровоизлияний. Соски зрительных нервов бледноваты. Дияноз: начальнал атрофия сосков зрительиых нервов. За время пребываня

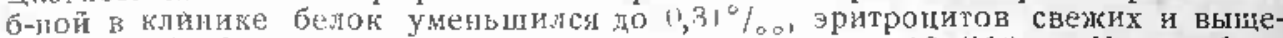
лочентых $3-5$ в прелараге, кровянос давление улало до $131 / 111 \mathrm{~mm} \mathrm{Hg}$ столба.

$9 / \mathrm{V} 1935 \mathrm{r}$. больня лоступила в стационар водолечебниды с диагнозом: жножественыъе кровонзлияния в мозг пा сле эклахпсии, хронический нефрит, склеротическая почка Кровяное давиение-1.5 $\mathrm{mm} \mathrm{Hg,} \mathrm{ниогда} \mathrm{доходит} \mathrm{до}$ 18: mт Нg. В моче цмеется белок, цилиндры, зритроциты, удельный вес низкий. Зрение - $1,1,2-1,13$, со стороны глазното дна-полная атрофия соска зрительпго нерва. Б области желтого пятна тигментные очаги. Поле зрения хужено.

\section{У этой больной альбумичурический ретинит осложнился атро-} фией зритеиьныхнервов. Со стороны почек-sтления хронического нефрита и силеротическая почка. Не исклюгена, по мнению невропатологов, возможпость, что больная до беременности страдаға диссеминированным склерозом.

4. Больная X,, 25 лет, постулила в экушерскую клинику $22 / \mathrm{XX} 1936$ г. для ңаблюдения по поводу презкамлтщеского состояния. Жалобы на головную боль и понияение зрелия. Общее сосгояне удовлетворнгельяое. Значительные отеки кони живота и голеней. Беременость около 8 мссяцев. Кровяное давление $19, \mathrm{~mm} \mathrm{Hg.} \mathrm{B}$ моче $3,7 \%$ со белта.

2 /IX венесекция-выпущено 400 см $^{3}$ крови, кровяное давление упало до 180.

$25 / 1 X$ исследование окулиста: зрение правого гілая $=(1,5$, зренне левого тлази $=0$, 1 . Колтуры сосков зритсльоло первз смазаны, сосулы узковаты. В левом глазу кннзу й киутри от соска вндны округлые проминирюшие, әксудативные очаги, отделыне мелке отаги по сосудам. На дис правого глазд-мелкае эксудативные очауи в обласли жеттоло хитна. Диагноз: альбуминурический ретини беременных. Рекомендовяно прерватъ беременость.

$26 / \mathrm{LX}$ кровяное давление $180 \mathrm{~mm} \mathrm{Hg}$. Кссарево сечение.

$2 \% / \mathrm{X}$. Vis, oc. d. $=1,0$ ?, Vis. 0. s. $=0,2$. Контуры сосков смазаны, эксудативные одаги уменъились в размерах и нерезко контурнруются. За время пребывания в клинике мас. кровпнос давленне колебалссп в пределах между 14.)-I15. Количество белка в моче умсньшиосы до 1,59\% \%о, имсктся единиआые эритродиты и гиалиновые цилиндры.

$25 / \mathrm{X}$ зрение правоғо глаза-0,7, зрение певого глаза-0,8. Соски зрительных нервоц бледн, особенно в височной половйе. В области жслтого пятн остатки альбуминуических бляшек. Кровяное давдеяие $120 \mathrm{~mm} \mathrm{Hg.} \mathrm{В} \mathrm{моче}$ $0,033^{\circ} /$ 。 белка, единичіыс эритролиты.

$25 / V^{\circ} 37$ г. Зрение оболх глаз 1,1. Соски зрительных нервов бледноваты, особеєно с височной стороны, сосуды узки, бляшек нет.

Быстрое улушшение зрения после прекрашцени беременности, исчезновение альбуминуричских звезд, улучиение общело состояния, нормальное жровяное давление и почтя нормальная моча дағот оснозание думатғ о нефропатии беременных. Но и здссь процесс оставнл свой след в виде деколорации сосков зрительных нервов.

5. Больная Л., Зо лел, поступила в терапевтическую клинику ДМһ 24/5V 1937 г. с жалобами на сильную толовную боль, отечность иища н ног и понижени зрения. У больной была тервая 7-месячняя беременность. 12/IV ннезано заметила ухудшение зрения в правом, а потом и в левои глазу. $19 / \mathrm{IV}$ родила мсртвого ребенка. В детстве перенссла заболсвание попек, в 1935 годунаблюдалась дважды гематурия.

Общи status-отеки иа ногах, лицо одугловатое, граница сердца увеличена влево га $1 / 2 \mathrm{~cm}$. Акцент на аорте, риты галопа. Кровяное давление $19-137$ $\mathrm{mm} \mathrm{Hg.} \mathrm{Моча-} \mathrm{удсльнын} \mathrm{всс-1} \mathrm{1н,} \mathrm{белка} 0,26 \%$, имеются единичные выне-

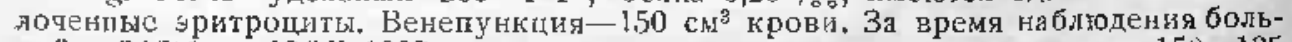
ной с 24/IV по 12/VI 1937 г. макс. кровяное давзенис понизилось до $150-135$ 
тп Нg, ғоловная боль уменьшилась. Моча: улельный вес в пределах 10101016 , белка $0,74^{\circ}$ оо, 3-4 әритропита в поле зрения.

"8/1V после венепункци зрение правого глаза--1,n, зрение тевого глаза(3,02. Дно обонх глаз: соски зрительных нервов гигерсмированы, контуры их стушеваны, вокруг сосков много эңсудативіы, лроминирующих очагон, в праном глазу парамакулярных, в левом-в области желтого пятна, При дальнейшем јаблюдении острота зрения левого глаза поднялась до 0,1 .

На месте 6 нших эксудативых очагов альбұминурические звезды больших размеров. По ходу сосудов кровоизлияния. Сосок зрнтельного нерва правсго глаза невритидеский, в лељом-бледноват, с паклонностьк к атрофии.

Длительность заболевания после родов, стойкость и прогрессирование глазных изменениё в сочетании с анамнезом и объективными данными заставляют думать, что в данном случае также имеется хронический нефрит. Онончательный диагноз может быть поставлен после более длительного наблюдения.

Итак, из приведенных пяти случаев альбуминурического регинита два явились следствием нефропатии беременных (1-й н 4-й), в остальных трех нмелся хронический нефрит.

Три случая осложнились атрофней соска зрительного нерва, последняя намечается и в пятом случае.

Что касается срока беременности, то только в одном, закончившемся летально, альбуминурический ретинит наступил в первой половине беременности, в остальных 4-х-во второй половине. Прервана беременность по глазным пгоазаниям во 2-м, 3-м и 4-м случаях. В первом наступили своевременные, а в пятом-преждевременнье роды.

Первый и второй случай альбуминурического ретинита наб̈людаются у повторно-роднгци, остальные-у первородяџих.

Bыводы: 1. Довольно распространенное представление об альбуминурическом ретините беременных как о болезни, протекаюпцей благоприятно $н$ с хорошим исходом, нуждается в серьезэьх коррективах.

2. Альбуминурический ретинит у беременных явльется лишь эокальным пронвлением в глазу общего тяжелого нарушения обомена.

3. Необходимо различать две груплы этих страданий:

а) 'альбумннуржческий ретинит у женцин, не страдавших до беременности заболеваниями почек;

б) альбуминурический ретинит у женшин, страдавших заболеванием почек и до беременности.

4. У беременных и рожениц, страдающих токсикозом с нефропатией и альбуминурическим ретинитом, при своевременных лечебных мероприятих ироцесс постепенно затихает и на иротяжении $1 / 2-1 \frac{1}{2}$ пет совершенно ликвидируется.

5. У лищ с дискрелитированной выделительной системой почек токсикозы беременности могут обострять старые хронические процессьг в почкх; у әтих лиц альбуминурический ретинит в прогностическом отношснии является не менее грозным признақом, чем у мужчии и небеременных женцин. Более того, токсикоз, родн, кормление лишь усложняют течение процесса.

6. ІІри исследовании беременной с альбуминурическим рети- нитом очень трудно точно выяснить патогенез и отнести забо«Каз, мед. журн;» № 12, 1937 г. 
левание к той или иной группе. Во многих случаях лищь дальнейшее наб̆'іодение позволяет точно решить этот вопрос, между тем как нередко требуется срочное вменательство.

7. При тяжелых общих и локальных (шри r. а. g) янлениях токсикоза показано безотлагательное ирерывание беременности.

8. При недленном нарастании токсикоза, нефропатии и при удовлетворительой функии органа зрения у лиц с беременностью больне $7 \%$ месянев возможно осторожное выжидание и в отдельных случаях нормальное разрепение родов с последуюпей регрессисй патологического процесса.

Из Омской дорожной стинци переливаня крови (зав. стапиией П. И. Вахрамесв)

Лечение переливанием крови помутнения стекловидного тела.

\section{П. И. Вахрамеев и Н. А. Борисов.}

Помутнение стекловидного тела представльет собой далеко еще пе выясненное заболевание. Этиологиеским фактором считают тубернулез, сифилис, другие инфекционные заболевания, гемофилию и пр. Все это указывает на то, что патологический процесс в стекловидном теле есть результат заболевания всего организма, а пе заболевание одного органа, и поэтому лечение должно иметь в виду общее воздействие на организм. Помутнение стекловидного тела характеризуется ицогда внезапной потерей зрения, отсутствием болевых спмтомон; офталмоскопически обнаруживаются нитевидные нли пғлеобразные помутнения, которые закрывают глазпое дно от иследования. Мғ считаем целесообразным упомянуть отдельно о помутнени стекловидного тела на пювне травмы. Эта форма развивается, в противоположность указанным, медленно и диет стойке изменения, а при офталмоскопии иомутнение имеет вид гомогенной массы. При этом виде заболевания локальное ноздействие на глаз, а также переливание крови не иметот успеха. I Там принлось встретиться с 3 случаями подобного вида помутнений. Зрение у всех 3 больных было резко понижено, и дальнейние наблюдения за ними не принесли нам положительных результатов. Всего через станцию переливания крови с 1933 по 1935 г. прошло 14 случаев и с 1935 по 1937 г. включительно 9 случаев (не считая трех упомянутлх) помутнения стекловидного тела на почве травмы. Во нсех 23 слугаях заболевание развивалось в течение первых суток и приводило к частичной или полной потере зрения на второй глаз. Первой группе больных в 14 человек применялось следующее лечение: обле-укренляющие, внутрь иод, ванны, аутогемотерапия, грязелечение и местное воздействие на глаз в виде атропина, дионина. Больные находились на лечении в стационаре от 2 до 4 месяцев. Понутнение стекловидного тела очень медленно шло на убыль, зрение. с 0,06 увеличивалось до $0,3-0,5$, и к концу выписки нз отде- 
ления у всех 14 больных остались в различной стелени помутнения. Из 14 человек к нам вновь вернулись для повторного лечения 5 больных. Лечение и наблюдение за ними убедили нас в том, что стойкого излечения у них не последовало. Всех больных мы шоднергали тщательному телесному осмотру, лабораторным и рентгеновскому исследованиям. Исследовали кровь на люэс. Все перечисленнюе виды исследования не дали нам возможности связать нроцесс в стекловидном теле с каким-либо заболеванием. Однако все 23 больных настойчиво утверждали, что заболеванию предшествонал грип. В какой мере грипозное состояние явилось причиного помутнения стекловидного тела, сказать трудно, однако исключить этот фактор нельзя ввиду того, что все 23 больных упорно указывали на потерю зрения после перенесенного ими грипа.

Ниже мы приводим таблицу данных, полученных нами при консервативном лечении помутнения стекловидного тела.

Таблица 1.

\begin{tabular}{|c|c|c|c|c|c|c|c|}
\hline № & $\begin{array}{c}\text { Начало } \\
\text { заболе- } \\
\text { вания }\end{array}$ & \begin{tabular}{|c|} 
Через \\
сколько \\
дней \\
поступил
\end{tabular} & $\begin{array}{c}\text { Зрение } \\
\text { прн по- } \\
\text { стулле- } \\
\text { пик }\end{array}$ & Летение & $\begin{array}{c}\text { Лродол- } \\
\text { жиель- } \\
\text { ность } \\
\text { течения } \\
\text { в мес. }\end{array}$ & Рецидив & $\begin{array}{c}\text { Зрение } \\
\text { при } \\
\text { выгиске }\end{array}$ \\
\hline $\begin{array}{l}1 \\
2\end{array}$ & Cpazy & $\begin{array}{r}3 \\
10\end{array}$ & $\begin{array}{c}0,04 \\
0,05\end{array}$ & Грязи & $\begin{array}{l}3 \\
21 / 2\end{array}$ & $\begin{array}{c}\text { Рецидив } \\
\text { Нет }\end{array}$ & $\begin{array}{l}0,4 \\
4,5\end{array}$ \\
\hline 3 & Постел. & 11 & $\left|\begin{array}{c}0.02 \\
06 a \text { глаза }\end{array}\right|$ & $\mu$ & 3 & Рецидив & 0,3 \\
\hline 4 & Cpasy & 14 & $\left|\begin{array}{c}0,04 \\
06 a \\
\text { rлаза }\end{array}\right|$ & , & 3 & " & 0,3 \\
\hline $\begin{array}{l}5 \\
6\end{array}$ & 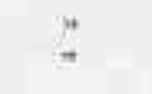 & $\begin{array}{l}5 \\
7\end{array}$ & $\begin{array}{c}0,1 \\
0,1 ! 5 \\
\text { оба } \text { ราเ }\end{array}$ & $n$ & $\begin{array}{l}2 \\
3^{1}:\end{array}$ & $\begin{array}{c}\text { Нст } \\
\text { Редидив }\end{array}$ & $\begin{array}{l}0,5 \\
0,4\end{array}$ \\
\hline $\begin{array}{l}7 \\
8\end{array}$ & Постеп. & $\begin{array}{r}12 \\
9\end{array}$ & $\begin{array}{r}0,113 \\
0,02 \\
\text { оба глаза }\end{array}$ & : & $\begin{array}{l}21 ; 2 \\
3\end{array}$ & $\begin{array}{c}\text { Hерт } \\
\text { Рецидив }\end{array}$ & $\begin{array}{l}0,3 \\
0,4\end{array}$ \\
\hline $\begin{array}{r}9 \\
10 \\
11\end{array}$ & Cpasy & $\begin{array}{r}13 \\
4 \\
2\end{array}$ & $\begin{array}{c}0,(15 \\
0,04 \\
0,02 \\
062 \text { глаза }\end{array}$ & " & $\begin{array}{l}2 \\
11 / 3 \\
2^{1 / 2}\end{array}$ & $\begin{array}{c}\text { Нет } \\
\text { Неизв. }\end{array}$ & $\begin{array}{c}\text { оба глаза } \\
0,5 \\
0,3 \\
0,2\end{array}$ \\
\hline $\begin{array}{l}12 \\
13 \\
14\end{array}$ & " & $\begin{array}{l}1 \\
5 \\
2\end{array}$ & $\left|\begin{array}{l}0,1: 5 \\
0,13 \\
0,05\end{array}\right|$ & 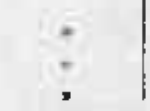 & $\begin{array}{l}2^{1 / 3} \\
3 \\
4\end{array}$ & $\begin{array}{c}\text { Нет } \\
\text { Рецйдив }\end{array}$ & $\begin{array}{l}0,5 \\
0.5 \\
0.3\end{array}$ \\
\hline
\end{tabular}

У всех больных р. Вассермана отрицательна, Из 14 случаев в 5 отмечен рецидив, у остальных больных - незначительное восстановление зрения; помутнение остается в стегловидном теле в виде пыли, и срок лечения затягивается от 2 до 4 месяцен, иричем отдаленны резу резутат у поступивших с рецидивами неудовлетворительный, и после повторного лечення зрение вяло нарастало. Почти в $50 \%$ отмечается двустороннее помутнение стекловидного тела. Больным проводилась аутогемотерапия больщими дозами, но безрезультатно.

Вторая группа обнимает 9 случаев помутнения стекловидного 
१ела. Этим больным ғ качестве лечения ироизводилось перели вание крови. После персливания крови очень быстро исчезало помутнение, и зрсние восстанавливалось, срок пребывания больных на койе редко доходил до 4 недель; кроме того, во всех случаях мы имели стойкий рсзультат, за исключснием одного случая, гдс настуцил рецидив. Прослеженные отдаленные результаты удивлетворителыны, 1 с ними не могут сравниться ранее полученные результаты от щрименения локальной тераиии. Переливание крови, воздействуя на весь орэанизм, имеет несомненное преимушество перед ранее примененным методом лечения помутнсний стекловидного тела. Физико-химические изменения стекловидного тела, пропитывание его белковым эксудатомвсе эло способствует выпадению органических н неорганических составных частей, вследствне цего и происходит нарушение прозрачности стекловидыого тела и появляются помутнения в виде пнли, тяжсй, хлопьев, как результат наруцения коллоидного ранновесия. Проявление местного патологического процесса в виде помутнения стекловидного тела есть комбинация нескольких причин. Этот процесс поддерживается и прогрессирует до тех пор, пока не наступит равновесия в белковых коллоидах.

У болыных второй группы (9 случаев) мы также проводили исследование жрови на сифилис с отрицательным результатом; обследовали их рентеном и производили лабораторные исследования так же, кақ и в первых случаях. $M_{\text {н }}$ установили, что помутннию стекловидіого тела предшествовало грипозное coctosние. Лечение помутнения стекловндного тела больных II группь сводилось к грименению 2-3-кратного переливания крови, после чего зрение резко улучиалось, помутнение становилось мсньше. Глазное дно стало достуіно осмотру. Кроме переливания крови больным назначалось уснленное питание; местное воздействие на глаз не применялось. Кровь переливалась небольшими количествами: 100-200 смّ. Интервалы между первым и вторым переливанием крови колебались от 5 ло 7 дней, В двух случаях нами было ироизведено переливание крови по $300 \mathrm{~cm}^{3}$. IЈосле этих переливаний наступнла резкая реакция, восстановление зрения затянулось. Герелитая групна крови была одноимениой, и мы в дальнейлгем отказались от применения больших доз. Причину этого нало усматринать в более резком воздсйствии на клстку в процсссе коллоидоклазии. ІІринодим наблюдения над больными при переливании крови с отдаленными хорошими результатами (см. табл. 2).

P. Вассерманаз у всех больных отрицательна.

Гаким образом, из 9 случаев рецидив настунил у одного больного, который к нам прнбыл через 2 месяца, в дальнейшем мы видели его через 14 месяцев и наблюдали стойкий эффект с повыленным зрением. В четырех случаях отмечалось двустороннее ломутнение стекловидного тела, и у всех 9 больных наблюдалось пониженное зрение другого глаза, хотя видимых жзменений в глазу офталмосколически не наблюдалось. Это понижсние выражалось от 0,2 до 0,4 . Надо полагать, что и во 
Таблица 2.

\begin{tabular}{|c|c|c|c|c|c|c|c|c|}
\hline No & $\begin{array}{l}\text { Начало } \\
\text { заболев. }\end{array}$ & $\begin{array}{c}\text { Чсрсз } \\
\text { сколько } \\
\text { дней } \\
\text { |поступй }\end{array}$ & $\begin{array}{l}\text { Зрсиие } \\
\text { мри по- } \\
\text { ступле- } \\
\text { нии }\end{array}$ & 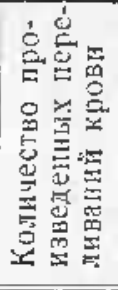 & 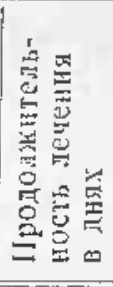 & Регидия & $\begin{array}{c}\text { Зрение } \\
\text { при } \\
\text { выписке }\end{array}$ & $\begin{array}{l}\text { Отдален, } \\
\text { результ. } \\
\text { зрения } \\
\text { через }\end{array}$ \\
\hline 1 & Сpasy & 14 & $\mid \begin{array}{cc}0,02 \\
06 а \\
\text { глаза }\end{array}$ & 2 & 16 & Нет & 0,8 & $U, 9 \quad 1 \quad \Gamma$. \\
\hline 2 & $\eta$ & $1 ! 2$ & $0,0.5$ & 3 & 21 & * & 0,7 & $0.8 \underset{8}{0}{ }^{0}$.. \\
\hline 3 & Постег. & 14 & $\begin{array}{c}0,01 \\
06 а \text { глаза }\end{array}$ & 3 & 25 & $=$ & 0,7 & {$\left[\begin{array}{c}0,9 \text { через } \\
1 \text { год. }\end{array}\right.$} \\
\hline $\begin{array}{l}4 \\
5\end{array}$ & Cpasy & $\overline{\mathrm{Cpa}} \overline{\mathrm{Y}}$ & $\begin{array}{l}0,0 \mathrm{I} \\
0,03\end{array}$ & $\begin{array}{l}2 \\
2\end{array}$ & $\begin{array}{l}30 \\
16\end{array}$ & $=$ & 0,6 & $9,8 \quad 1 \frac{1}{2} \mathrm{r}$ \\
\hline 8 & $n$ & 14 & $\left\{\begin{array}{c}0,07 \\
\text { оба глаза }\end{array}\right.$ & 2 & 26 & Рецидд. & $\begin{array}{l}1,0 \\
0,5\end{array}$ & $\begin{array}{l}1,014 \mathrm{M} \\
0,814 \mathrm{M} .\end{array}$ \\
\hline 7 & Поостел, & 30 & 0,06 & 2 & 20 & Het & 0,6 & $0.72 \mathrm{r}$. \\
\hline 8 & Cpa3y & Cpasy & $\begin{array}{c}0,03 \\
\text { оба глаза }\end{array}$ & 2 & 29 & $"$ & 0,5 & $0,7 \quad 10 \mathrm{~s}$ \\
\hline 9 & • & 5 & 0,03 & 2 & 12 & F & 0,7 & $0,89 \mathrm{Mm}$ \\
\hline
\end{tabular}

втором глазу в стекловидном теле имел место патологический ироцесс в виде молекулярных изменений, которые не давали заметных изменений при исследовании, Болыной процент двустороннего помутнения стекловидного тела в значительной степени подтверждает вғсказанную равее точку зрения, что помутнение стекловидного тела есть симптом болезни всего организма.

Наши сравнительно немногочисленные наблюдения позволяют нам высказаться за целесообразность применения переливания крови при помутнениях стекловндного тела. Переливанием крови мы воздействуем на патологическую структуру биоколлоидов стекловидного тела.

В литературе $ы$ нашли две работы: Архангельского, опубликованную в журнале „Врачебное дело“, и Баташева и Крьлова, огубликованнуг в журнале „Гематология" за 1936 г. Упомянутыс авторы описывают случаи с хорошим результатом от лечения переливанием крови помутнения стекловидного тела.

Баташев, Крылов лриводят наблюдеиия над примененисм ау тогемотерапии при помутнении стекловидного тела, нс давшей эффекта. Первой группе наших больных в 14 человек также применялась аутогемотерапия, но была оставлена. При леченик же помутнения стекловидного тела переливанием крови мы получили хорсший эффект и стойкий отдаленцый результат.

Выводы: 1. Помутнение стекловидного тела-страданис в этиологичесом отношении далеко епце не ясное.

2. Помутнение стекловидного тела одного глаза, видимо, дает молекулярные белковые изиенения в стекловидном теле второго глаза, что обусловливает понижение зрения второго глаза от 
0,2 до 0,4. Это подтверждается высоким процентом двустороннего помутнеиия стекловидного тела и падением зрения.

3. Помутнение стекловидного тела травматического характера зависит, видимо, также от обцих причин; здесь переливание крови успеха не ииеет

4. Переливание крови эвляется могучим средством в ледении помутнения стекловидног тела; при этом: а) срок печения сокрап(ается, б) зрение восстанавливается быстро, в) помутнения исдезант соверпенно, г) отсутствуют рецидињ, д) получается стойкий отдаленный результат.

Jз кафедры патофизиоиогии қуб. мед. и-та (зав. каф. проф. А. А. Медких).

\section{Влияние пищевого режима на феномен Артюса.}

\section{А. Н. Гордиенко и З. В. Старосветская.}

Ученис об аллергии в последнее мрсмя достилло больиих успехон. Благодаря успехам в области экспериментального изучения аллергин стало возиожным объяснить патогенез многих заболеваний. Одним из неразрешенных вопросов аллергии яв.ляется десепсибиизация аллергических состояний. Десенсибилизация по Безредка дает хорогие результаты только против общей анафи. аксии и родственной ей сывороточной болезни. Что касается аллергических заболеваний, как бронхиальная астма, сенная лихорадка и т. д., то метод десенсибилиздции по Безредка не дает тех рсзультатов, какие получены при экспериментальной анафилаксии и сывороточной болезни. Трудности десенсибилизацни при этих заболеваниях заклюшаетсн в тон, что не нсегда удается установить природу аллергена, вызвавцего это заболевание, а тақе в том, что введение аллергена нередко днет бурную обццю реакцию.

Местные аллергические пропессы отличаттся от общей анафилаксии тен, что десенсибилизировать животное при аллергическом состоннии, пользуясь методом десенсибилизации по Безрсдка, потти невозможно, а при такон состоянии, каким янляется феномеі Артюса, и совсем невозможно. Не случайно многие стремились найти новые способы десенсибилизации цри местных гилерергических процессах в форме рентғеновских лучей, грязей, минеральных вод, различных солей и т. д.

В настонщее время имеются факты, указынаюшие на зависимость между питанием и реакцией организма. Так, енце 20 лет тому назад Люитлен показал в олытах над кроликами, что кормление кроликов исключительно овсом повышает реактивность кожи к восиалительному раздражению, а кормление исключительно зеленью понижает ее. Это явление Люнтлен объясняет изменением ионного состава кожи, а именно: при этом происходит сдвиг в сторону $\mathrm{K}$ против Са и $\mathrm{Mg}$ прн питании овсом 
и сдвиг в сторону Са и $\mathrm{Mg}$ против $\mathrm{Na}$ и К при кормлении зеленьк. В дальнйшем многие авторы подтвердили данные Люитлена. Клаудер и Броунер при овощном режиме в $70^{\circ}$ сл слчаев получили шониженную реактивность кожи. Хаяши и Ногуши гакже установили зависимость между реактивностью кожи и эишевым режимон. Талалаен указывает, что избыточное питание углеводами создает возможность получения феномена Артюса у собак. Герценб́ррг, Ильнна и Денисова изучали влияние белковой диеты. на течение феномена Артьса у крыс. При этом авторы указывакт, что феномен Артюса выражен сильней при белковом гитании, чем гри комбинированном. Tе же авторы наблюдали усиление феномена Артіса при авитаминозе $\mathrm{A}$.

В связи с этим лредставляет несомнепний интерес влияние витамила $C$ на течение аллергических процессов. Жиру вперные указал на то, что аскорбиновая кислота предохраняет жнвотных от развития анафилактического шока. Кролики, предварительно обработанные иньекцией аскорбиновой кислоты, в 17 опытах не дали ни одного иока, в то время как не обработанные аскорбиновой кислотой дали после разренающей дозы 12 смертсльных случлев из 17 олытов. В дальнейшем тот же автор показал, что питание кроликов обычным кормом с прибавлениен язбытка свежей люцерны и листьев канусты в значительной степени уменьшает количество сыертельных исходов после разрешающей иньекции по сравнению со смертельными исходами у кроликов, получанших сухой корм. Одиовремепное исследование содержапия аскорбиновой кислоты в органах у кроликов иоказало, что кролики, получавшие капусту, содержат почти вдвое больше аскорбиновой кислоты, чем кролики, получавшие сухой корм. Шпитц и Гохвальд также установили, что введение аскорбиновой кислоты перед разрешаюцей дозой сенсибилизированным собакам предохраняет или резко уменьшает у больиннства собак развитис анафилактического шока.

Влияние пиши, богатой витамином $\mathrm{C}$, на местныс аллергические процессы указанными авторами не исследовано. О влинния авитамнноза С на местную аллергию было сообщение Харасаньин-Таде, проводившего свои опыты на морских свинках, из которых одна часть получала пищу без витамина $C$, вторая часть без витамина $C$ и $\mathrm{A}$. По наблюдениям автора авитаминоз $\mathrm{C}$ повыпает реактинность кожи, а комбинированный авитаминозпонижает.

Использование свинок для этой цели представляет некоторое иеудобство: c одной стороны, свинки очень чувствительны $k$ авитаминозу $C$ и, с другой стороны, очень мало пригодны для опытов с феноменом Артюса. Кроме того, упоминутый автор занимался исключительно авитаминозох и нс выяснял роли пищи, бог'атой витамином $C$.

Влияние пищи, богатой витамином C, на аллергические процессы представ.тет, несомненно, теоретический интерес и имеет практическое значение.

С этой цельо нами были шоставлены опыты на 30 кроликах, 
қоторые были разбиты на 3 количественно равные групиы: кро‘ики 1-й труппь получали исключительно сухой корм (овес и сено), кролики 2-й группы получали овес, сено и в избытке сирую капусту. Кролики 3-й групाы получали овес, сено и в избытке вареную капусту. Исследования Жиру показали, что дача кроликам в избытке свежей калусты ведет к большому накоплению аскорбиновой кислоты в их органах. Әто исследование послужило нам основаниен включить свежуло капусту в пищевой рацион опытнға животных и тем самым способствовать накоплению витания $C$ в орланах. Вареная капуста, в которой разрушен витамин, была вклочена с той џелью, чтобы рационы второй и третьей группы кроликов отличались только содержанием витамина C.

До начала сенсибилизации кролики в тетение 2 недель получали указанный пмнцевой рацион. IІосле 2-недельного пребыॐания кроликов на соответстнугылем рационе было ғачато введение лошадиной сыворотки лод кожу в количестве 2,5 см $^{3}$ с интервалом в 5 дней. Кролики все зрсия оставались на описанном рационе. Такая сенсибнлизация подкожным введением сыворотки позволила нам наблюдать не только конечный результат опыта, но и скорость развития феномена Артюса.

В таблице 1 мы принодим конечный резуыьтат после 7-кратного введения сыноротки под кожу. В таблице кожные явления после 7-й иньекции разбить нами на 5 групп:-отсутствие изменений на месте введения, -† едва прощупываемый инфильтрат, ++ значительный инфильтрат, -; ++ большой инфильтрат с покраснением и $十++\div$ некроз на иесте введения сыворотки.

Таблида 1.

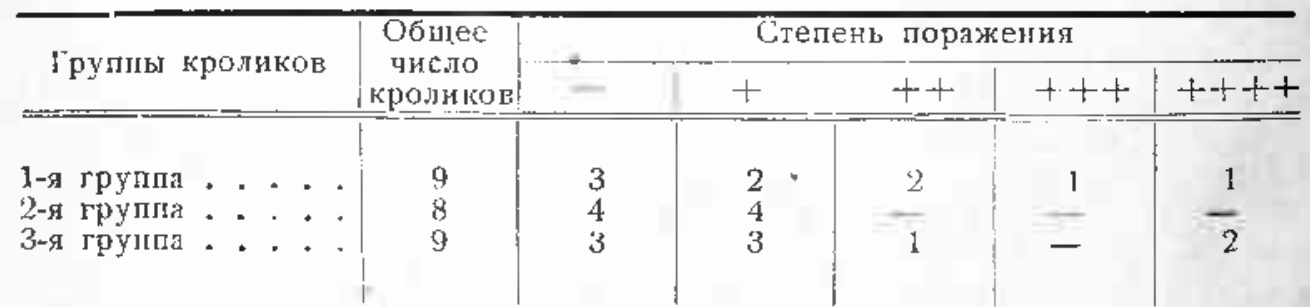

Из этой таблицы вицно, что 1 -я группа кроликов дала большее количество аллергических изменений, чем 2-я группа. Если принять но внимание тяжесть аллергческих изиенений, то 2-я групла дала незначительные, в то время как l-я группа дала более резко выраженные аллергическе изменения. 3-л группа зани мает среднее положение.

Если посмотреть скорость аллерлических изменений после каждой иньекции (табл. 2), то можно заметить, что кролики 1-й lруппы, начиная с 4-й иньекции, дают в большем количестве аллергические изменения, чем кролики остальных групп и в особенности 2пй. 5-я иньекция дала более выраженное различие между отдельными гругпами, при 6-й иньекции әти различия стираются и гри 7-й иньекции внонь наблюдаются более сильные изменения в 1-й группе. 
Габлица 2.

\begin{tabular}{|c|c|c|c|c|c|c|c|c|}
\hline \multirow{2}{*}{$\begin{array}{r}\text { lруппь } \\
\text { кродиков }\end{array}$} & \multirow{2}{*}{\multicolumn{2}{|c|}{ Иньекп. }} & \multirow{2}{*}{$\mid \begin{array}{c}\text { Общее } \\
\text { гисло } \\
\text { кроликов }\end{array}$} & \multicolumn{5}{|c|}{ Crenень пораженяя } \\
\hline & & & & $=$ & + & it & $+t+$ & $++\frac{1}{1}+\frac{1}{1}$ \\
\hline I sp. & $\begin{array}{l}3-9 \\
4 \\
5 \\
6 \\
7\end{array}$ & $\begin{array}{l}\text { urt. } \\
" \\
" \\
"\end{array}$ & $\begin{array}{l}9 \\
9 \\
9 \\
9 \\
9\end{array}$ & $\begin{array}{l}7 \\
3 \\
1 \\
5 \\
3\end{array}$ & $\begin{array}{l}2 \\
4 \\
3 \\
2 \\
2\end{array}$ & $\frac{\overline{2}}{\overline{2}}$ & $\frac{-}{5}$ & $\overline{-}$ \\
\hline $25 \mathrm{p}$. & $\begin{array}{l}3+9 \\
4 \\
5 \\
6 \\
7 \\
\end{array}$ & $\begin{array}{c}\text { й } \\
* \\
* \\
\end{array}$ & $\begin{array}{l}8 \\
8 \\
8 \\
8 \\
8\end{array}$ & $\begin{array}{l}3 \\
6 \\
3 \\
2 \\
1\end{array}$ & $\begin{array}{l}3 \\
2 \\
5 \\
6 \\
4\end{array}$ & $\frac{2}{-}$ & $\frac{-}{-}$ & $\begin{array}{l}- \\
- \\
-\end{array}$ \\
\hline $3 г р$. & $\begin{array}{l}3-9 \\
4 \\
5 \\
6 \\
7\end{array}$ & $\begin{array}{c}\text { ин. } \\
" \\
" \\
"\end{array}$ & $\begin{array}{r}10 \\
10 \\
10 \\
10 \\
9\end{array}$ & $\begin{array}{l}6 \\
5 \\
4 \\
6 \\
3\end{array}$ & $\begin{array}{l}3 \\
3 \\
4 \\
3 \\
3\end{array}$ & $\frac{1}{2}$ & $\begin{array}{l}1 \\
1 \\
- \\
-\end{array}$ & $\frac{-}{-}$ \\
\hline
\end{tabular}

Нужно отметить некоторую особенность н развитии аллергических процессов у кроликов I-й группы, получавших сухой корм: если число кроликон с аллергическими изменениями среди 2-й и 3-й группы все время увеличивалось, то у кроликов, получавших сухой корм, нарастание шло до 5-й инъекции включительно, а затем число кроликов, дающих инфильтрат, уменьшилось. Но зато у кроликов, получавших свежую капусту, мы наблідали более быстрое рассасывание инфильтратов, чем у кроликов, питавшихся сухим кормом.

Патолого-анатомическое вскрытие кроликов, получавших сырую капусту, показало отсутствие гнойных образований на месте введения сыворотки даже у тех, которые были нами отмечены, как давшие аллергические изменения. В то же время у кроликов, получавших сухой корм, были установлены в подкожной клетчатке некрозы, которые при жизни не обнаруживались лрн ощупывании, и кролики были отмечены, как не давшие аллергических изменений. Микроскопические изменения послужат темой отдельного сообцения.

Рассматривая результаты наших опытов, можно сказать, что дача свежей капусты уменьшает тижесть аллергических изменений после введения лошадиной сыворотки. Образование инфильтратов при этом идет значительно слабее, чем при обыцных условиях, инфильтраты быстрее рассасываются. При даче свежен капусты кроликам мы не наблюдали образования некрозов, что характерно для феномена Артюса. Что касается влияния сухой пищи на развитие феномена Артюса, то кролики 1-й группы дают несомненно более резкую местную реакцию, нем кролики, получавшие сырую капусту; если соноставлять феномен Артюса у кроликов при сухом корме с теми результатами, которые мы получали неоднократно с той же сывороткой и при помощи той же методики при обычной смешанной пище, то 
иожно сказать, что сухой корм мало усиливает феномен и даже несколько задерживает его.

Во второй части наших опытов мы проверили влияние пищевого режима на развитие анафилактического пока. В этой части опьтов мы стремилисы проверить данные, которые были получены вышеназваныңми авторами. Для этой цели мы использозали тех кроликов, у которых мы получали феномен Артюса. После 7-й инъекции қролики были оставлены на прежней диете в тешение 15 суток. По истечения этого срока кролики полу цили внутривенно по $4 \mathrm{~cm}^{3}$ лошадиной сыворотки. При этом из 6 кроликов, получавших сухой корм, 5 дали анафилактижеский шок; 3 из них погибли сейчас же после введения сыворотки, 2 остались живы, один не дал шока. Из 8 кроликов, получавших свежую капусту, три дали анафилактический шок, остальные шока не дали, у кроликов, получавших сухой корм и вареную капусту, мы не вндели ни одного, даже слабого, nioka.

Таблида 3.

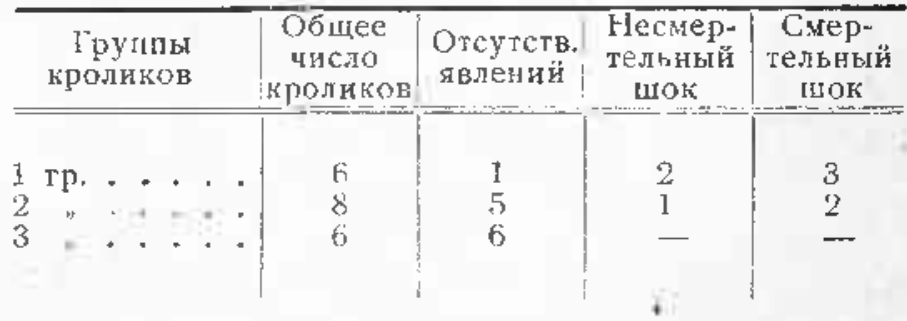

Принеденные в таблице и в тексте результаты свидетельствуют о том, что пребывание кроликов на сухом корме увеличивает их чувствительность к анафилактическому шоку. В то же время дача капусты уменьшает число сыертельных исходов после разрешающей инъекіци. Довольно парадоксалыиым является тот факт, нто из кроликов, получавших вареную капусту, ни один не дал щока. Это заставлнет думать, что в капусте имеются какие-то другие факторы, кроме витамина С, или же что для предохранения от анафилактического шока необходимо какое-то оптимальное количество витахина. Кигячение разрушдет только часть витамина C; при варке капусты даже в открытом сосуде активност витамина $C$ не вполне разрушается, а лишь понижается в 20 раз (Эдди, Щелоу, Пис, Рихтер и Уоткинс; цит. по Певзнеру); увеличение количества витамина при даче сырой капусты не ведет к прогрессивному уменьшению чувствительности к повторному введению сыноротки.

Различное влияние режияа на течение местных аллергических процессов и обшей анафилаксии лишний раз указывает на то, щто эти процессы имеют различные закономерности развития. В силу малой изученности патогенеза аллергических процессов, в настоящее время трудно сказать, каков механизм действия витамина С. Возможно, цто витамин С повышает окислительные цроцессы в клетках, как это полагают Џиитц и Гохвальд, и тем 
самым способствует более быстрому рассасыванию ннфильтратов, но можно допустить и другое толкование.

В последнее время было установлено, что повышение температуры животных при авитаминозе $\mathrm{C}$ занисит от повышения функщии щитовидиой железы. Более ранкими работами Кепинова, Бела, Лютихау было установлено, что удаление щитовидной железы у животных ведет к резкому уменьшению их чувствительиости $k$ повторному введению сыворотки. Блюм показал, щто введение тиреоидина морским свинкам, сенсибилизированным растительжым белком, ведет к более сильной реакции на повторное введение сыворотки. Щитовидная железа оказывает свое действие на вегетативную нервную систему, которая играет довольно важную роль в патогенезе анафилаксии.

Отсюда можно думать, что дача пищи, богатой витамином $C$, вызывает у животных значительную перестройку в нервно-эндокринной системе, что и оказываст свое влияние на тенение аллергических ироцессов и, в частности, на анафилактический шок.

Bsьоды: 1. Содержание животных на пищевом рационе с боль. шим содержанием витамина $\mathrm{C}$ ведет к уменьшению местных аллергических процессов.

2. Содержание животных на сухом жорме не усиливает местных аллергических процессов.

3. Содержание животных на сухом жорме, бедном витамином $\mathrm{C}$, ведет к увеличению обшей анафилактической реакции на повторнос введение сыворотки.

4. Прибавление свежей и вареной капусты в избытке к пнщевожу рациону уменьшает жоличество кроликов, дающих анафипактический шок на повторное нведение сыворотки. 
Из пабораторни чатологчческой физиологии ТИЭМ и Казанского roc. медњщиского иіститута.

\section{Динамика изменения колебанй глютатиона при зксперимен-} тальных пороках сердца.

\section{М. А. Ерзин.}

Понимане нехянизма декомпенсации сердца требует знания цак гемодинамических, так и протоплазмо-динамических факторов. Протоплазмо-динамические процессы интимно связаны с окислительно-восстанонительными гроцсссами. С этой точки зрения за последнее время придают большое значение глютатиону, как представителю термостабильной окислительно-восстановительной системы. После олкрытия Гопкинсом глютатнона ноявилось много работ, которые подтверждают нажную роль глютатиона, как окислительно-восстановительного фермента. Целой серией исследований (Гопкинс, Кендаль, Гроссман) установлено химическое строепие глютатиона, представляющего собой трипентид, состоящий из трех аминокислот: цистеина, глютаминовой кислоть и гликокола. Оказалось, что сульфидные групны SH глютатиона способны легко отдавать свой водород. с преврацением цистеина В цистин:

$$
\mathrm{CH}_{2} \mathrm{SH}+\mathrm{HSH}_{2} \mathrm{C}=\mathrm{CH}_{2} \mathrm{~S}-\mathrm{SCH}_{2}
$$

Гексанептид, присоединяя водород, вновь может носстанавливаться, образуя две молекулы глютатиона. Поэтому глжтатион встречается в двух формах: восстановлениой $\mathrm{SH}$ и окисленной-SS.

Когда глютатион в дисульфидной форме отщепляет от какогоино вещества нодород, то освобождаюцийся при этом в химилески активной форме кислород обладаст способностью вызывать харак'терное для тканевых элементов окисление. Таким образом глютатион может служить в организме переносчиком водорода н, благодаря паличию суль,гилрильных групп, является в этом отношешии катализатором, способстнул окислительновосстановительным процессам.

Пользуясь методнкой, предложепной Туннеклиф, ряд исследователей (Бланше, Бине и пр.) определили содержаиие глютатиона в различных органах и тканях. Они напли, что наибольшее количество его содержится в железистых органах (печень, иочки), тогда как в мышиах, в легких сго значительно меньше. В крови, по Голдэну, Хунтер и Иглис, он находится только в эрнтроцитах, причем в количестве, вдвое большем, чем в мышцах. В плазме крови его нет, как нет его и в хрящах. Габс наџел, что суцествует строгое соотношение между количеством гпютатиона и функциональной слособностыо мышц: наибольшее количество его содержится в сердечной мышие (Мунилла); затем в красных мыниах, нанменьшее-в белњх, обладающих 
наименьшей функционалыой способностьк. Злоканественные опухоли содержат больпе глитатиона, чем соответствующая жормальная ткапь. Эмбрион содержит глютатиона больше, чем злокачественная опухогь. В опытах Розенталя, Сонфорда и Веглиша у прис после продолжителынй мњшечной работы количество глютатиона в крови возрастало. В легочной ткани на $50-70^{\circ} \%$ находится глютатион в дисульфиттой форме $\mathrm{S}-\mathrm{S}$, в других же органах (иечень, селезенка и др.) -в восстановленной форме $\mathrm{S}-\mathrm{H}$.

Большой теоретический и клинический интерес представляют исследования относительно содержания глютатиона в крови. Глютатион находится в крови в сравнительно большем количестве, чем в других тканях, и содержится он исклюнительно в эритроцитах. Из исследований Габбе, который пользовался собственной методикой количественного определения глютатиона, видно, что в венозной крови на 90--98\% глютатион содержится в виде сульфгидрильной форми. В артериальной же крови от 60 до 100\% глютатнона бывает в виде дисульфидной формы S-... S. B эту форму он переходит в легких. В виду этого исследования глютатиона при сердечной недостаточности имет особенно больио значение.

Причины недостаточности сердца и оценка последней явғяется одной из самых неясных проблем патологии кровообрацения. Исследование одних только гемодинаминеских факторов не дает достаточно твердой опоры для функщиональной диагностики, и еле меньие-для понимания биохимических продессов в тканях при сердечно-сосудистой недостаточности. Сердечно-сосудистая система не является изолированной и независимой физиологической системой. Доставка О. тканям и эвакуирование продуктов метаболизма огределяет основную задачу сердечно-сосудистой фуниции, тем ную функциональную связь между

самым устанавливая интимсердечно-сосудистой системой и тканями. Следовательно, интенсивность метаболизма в тканях предьиляет опредспенные требования к сердетно-сосудистой системе.

Патологические изменения в клеточном химизме, отражающиеся на потреблении тканями кислорода, должны влиять на состояние сердецно-сосудистой системы и могут быть способствующими, а в некоторых случаях и первичными моментами, обусловливающими патологию кровообращения. Эти процессы в клетках, могущис играть роль патогенетических моментов в патологии кровообращения, Эппингер назвал протоплазмо-динамическими в отличие от гемодинамимеских. С этой точки зрения, по Эплингеру, патологн кровообращения является частью патологии обмена вепцеств, а сердечпого больного следует рассматривать как больного с расстройством обмена вешеств. Это делает необходимым оценку имеющихся данных о соотношении между деятельностью сердечно-сосудистой скстемы и окислительно-восстановительными процессами в тканях. В свете этих воззрений нам представнлось интересным выяс- 
нить механизм окнслительно-восстановительных процессов при әкспериментальных пороқах сердца у собак. С этой целью у подопытных животных мы вызынали экспериментальнуго недостатоцность аортального и трехстиорчатого килпанов сердца путем механического разрупения их.

Переходя к описанио явлений нарупения деятельности сердца и кровообрацения при педостатонности аортальных клапанов, мж должны указать на результать относяцихся сюда экспериментов, имегоци несомнени во многом руководящее значение пля правильной оценки характера клинических явлений недостаточности полулунных клапанов аорты. IН основания опытов искусственного прободения аортальных клапанов следует прежде всего отметить тот заслуживаюший интереса факт, что, несыотря на произведенное повреждение, наличность котирого определяется после травматицеского инсульта появлением характерного диастолического пума, артериальное давление сохраняется ня высоте, близкой к норме. Развивающаяся по истечении некоғорого времени, В зависимости о'т упомянутого воздействия на клананы дорты, гипертрофня мускулатуры левого желудочка сопровождается, как показывает наблюдение над вскрытыми сердцами жинотных, увеличением полости левой камеры, совериенно соответствуілцим клиническим явлениям. Получается так назызаемая экспентрическая гипертрофия. Описываемый шорок нслостаточности нолулунных клапанов аорты представляет, согласно экспериментальному наблюдению, мало отличнтельных черт от Данных кыиники. Наблюдаетсл характерная особенность пульса при названном пороке сердца у собак: он делаетсл полным и скорғм. За сильны растяжением сасудистой стенки следует ее бистрое сіадсние.

Описанные уклонсния от физиологических свойств сосуда являются, повидимому, одной из причин расстройств не только в капиллярном, но и в венозном кроворбращении. Исходя нз этого, нужно ожидать, что нарушение кровообращения, связанное с этим видом порока, должно неиосредственно влиять на протоплазмо-динамические процессғы в тканях, тем самым определяя и направляя динамнку окнслительно-восстановительных ироцессов в тканях.

Нзменения глютатиона при экспериментальных порокахсердца как в отечественной, так и в иностранной литературе не описанц. Имеюлциеся работы по изучению изменений глютатиона при сердечно-сосудистых заболеваниях у людей немногочисленны и подчас дают противоречивые результаты. Так, согласно Габбе, при состояниях диспноэ, недостаточности сердца, бронхиальной астме инет место увеличение глютатиона в крови. Вовси, Диксон, Яковлева отмечают довольно знасительное понижение глютатнона при тяжелых декомленсациях сердечно-сосудистой снстемы. По Малкину глютатион крови колеблется в нормальных пределах при болезнях органов кровообрацения в состоянии коипенсации. В свонх позднейших работах Малкин нашел, что при декомпенсированных сердечных пороках у людей резко 
увелидивается в венозной крови окисленная форма глютатиона́ и уменьшается восстановленная форма.

Пестрота результатов и противорецивость выводов различных исследователей по вопросу о содержании глютатиона крови шри болезнях аппарата кровообращения объясняктся, с одной стороны, недоучетом ряда привходящих моментов, могущих оказать влияние на уровень глютатиона крови (легочные, почечные, шеченочные, острые инфекционные процессы и т. д.), а с цругой стороны-различными пределами нормы глютатиона у людей в зависимости от применяемого метода определения. Большинсто исследователей, занимавшихся исследованием глютатиона при сердечно-сосудистых заболеваниях у людей, ограничивались определением только общего глютатиона. Между гем для вюяснения механизма окислительно-восстановительных процессов имеет значение определение обеих фракций глютатиона. Нас интересовал вопрос, как изменяются фракции глютатиона при чистых пороках клапанов сердца без принходяцих моментов. Мы определяли фракции глютатиона в крови у жиъотного с пораженными клапанами сердца во время развития патологического нроцесса.

Определенис обцего глютатиона нами производилось по методу Габбе, в принципе основанном на том, что при дейтвин. зольфрамовой кислоты все дисульфидные формы восстанавливаются. Восстановленный глютатион мы определяли осаждением крови трихлороуксусной кислотой по Бланшатье и Бине. При зтом восстановленный глютатион в неизмененном виде переходил в фильтрат. В дальнейшем мы придерживались методики Габбе. О количестве окисленного глютатиона судили по разности между общим и восстзновленным глютатионом. Параллельно с этим иы определяли индекс Габбе и ретикулоциты, желая проследить реактивность эритропоэтической системы при пороках сердца.

Наши экспериментальные исследования проведеиы на двух сериях собак, часть из них - c недостаточностью аортальных клананов, другая часть-с недостаточностью трнкуспидальных клапанов. У подопытных собак определялись фракции глютатиона крови на протяжении 15 и больше дней с тем, чтобы установить нормальную кривую колебания фракции глютатиона крови в норме и при пороках сердца.

Представленные таблицы и кривые свидетельствуют о строгой закономерности колебаний отдельных фракций глютатиона, дающих незначительное расхождение между общим и восстановленным глютатионом; это указывает на полноценность совершаюцихся окислительно-восстановительных процессов у обследуемого животного. Содержание ретикулоцитов в норме у собак колебалось в пределах от 0,48 до $0,5 \%$.

Как указано выше, опытные животные были подразделены на две группы. У первой группы собак мы изучали состояние окислительно-восстанонительных процессов в связи с недостаточностьо аортальных клапанов, у второи группы-в связн с не- 
достаточностью трехстнорчатого кланана. У собак первой группы, предназначенньх для налокения порока недостаточности аоргального килапнн, под морфийным наркозом обнажалась сонная артерия, периферический конец которой перевязынался лигатурой, центральный же конец-зажимался особой клеммой с подушечками, во избежание травмы стенок сосуда. Стенка артериғ в середнне этого отрезка надрезалась, и в это отверстие вставлялся серебряный пугончатый зонд. Для предупреждения артерияльнго кровотечения сосуд вокруг введенного зонда слегка перевязывался толстой шелковой ниткой, Затем клемма разжималась, планным движением зонда от периферии к центру мы нашупывали клапан и резким толчком зонда прорывали один или два клапана. Тотцас вслед за нарушением целости полулунных клапанов аорты, артериальный пульс приобретал скачуций характер, подъем и падение пульсовой волны были быстрыни. Вместе с тем выслушивался ясный диастолический шум, лучше всего--на месте сердечігол толчка. I Iосле наложения порока зонд вынимался из артерии, и оба конца артерии перевязывались. Накладывались швы. Рана в большинстве случаев зажинала без нагноеиий, первияны натяжением.

Таблица 1.

Таблица 3.
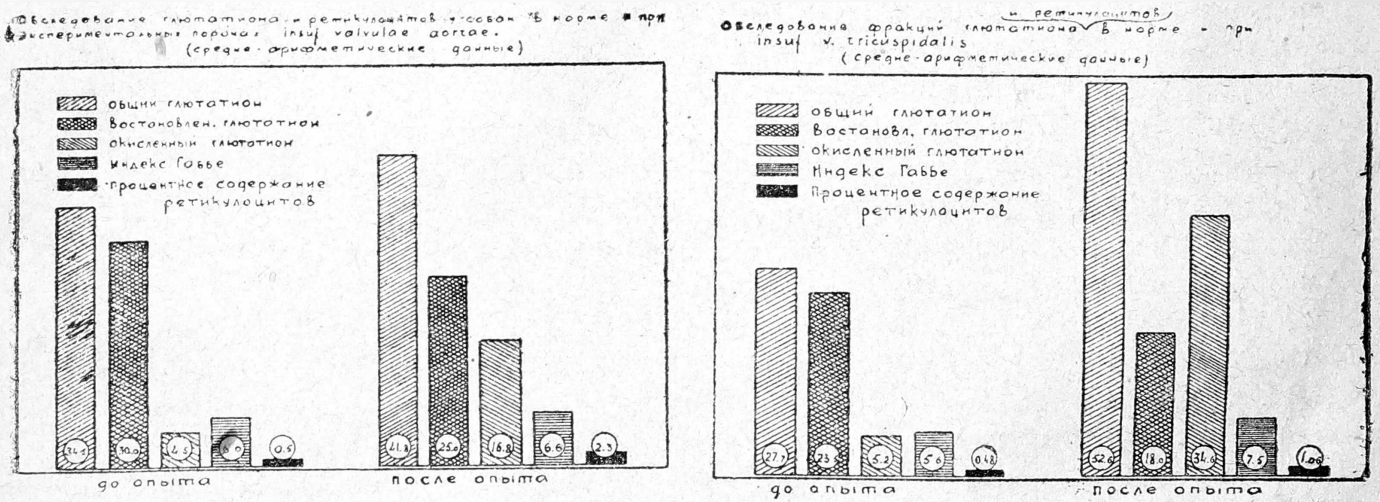

Исследование глютатиона мы обючно производили на другой, максинум на третий день. Фракции глютатиона определялись у некоторых собак ежедневно, у некоторых через день, в пронолжение того же срока, что и при норме. В таблицах 1 и 2 приведены цифры и кривые, показывающие изменение отдельных фракций глютатиона цри аортальных пороках. Из этих цифр видно, что по сравнению с нормой общй глютатион хотя и незнацительно, но нсе же увеличивается на 7,3 мго. Окисленная форма глютатиона возрастает по сравнению с нормой в $3 \frac{1}{2}$ pasa, т. е. возрастаст на I4,3 м $\%$, что указывает па значительное нарушение окислительно-восстановительных процессов шри экспериментальной недостаточности аортальных заслонок.

Прослеживая динамику изменения фракций глютатиона у собак с недостаточностью аортального клапана, мы установили интереснуг закономсрность: окнсленная форма увеличивается 


\section{Материал по обследованию глютатиона и ретикупоцитов у собак в норне и при зкепөрияентальных пороках}

\begin{tabular}{|c|c|c|c|c|c|c|c|c|c|c|c|c|c|c|c|c|c|}
\hline & \multirow[b]{2}{*}{$\begin{array}{l}\text { Iорода собак } \\
\text { и масть }\end{array}$} & \multicolumn{8}{|c|}{ Обсдедовано поо панения порока } & \multicolumn{8}{|c|}{ 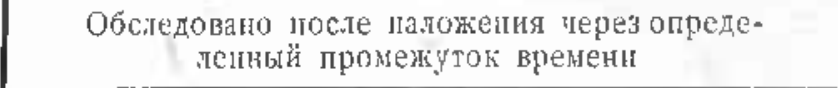 } \\
\hline & & 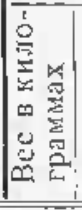 & $\begin{array}{c}\text { Время } \\
\text { опреде- } \\
\text { лепия } \\
\text { г.тюта } \\
\text { тиона }\end{array}$ & 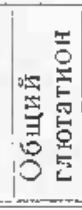 & 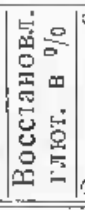 & 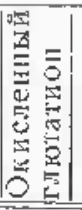 & $\begin{array}{c}\text { Колич, } \\
\text { эритро- } \\
\text { гциов } \\
\text { в I см'3 } \\
\text { m.m. }\end{array}$ & 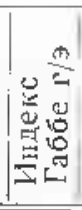 & 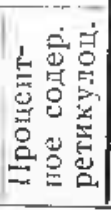 & $\begin{array}{c}\text { Вреня } \\
\text { ошреде- } \\
\text { ления } \\
\text { гіюта- } \\
\text { тиона }\end{array}$ & 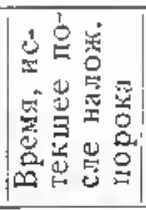 & 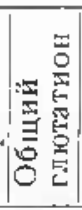 & 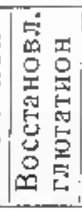 & 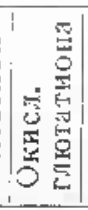 & $\begin{array}{l}\text { \$o.tise- } \\
\text { ство } \\
\text { эритро- } \\
\text { ци гов }\end{array}$ & 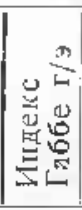 & 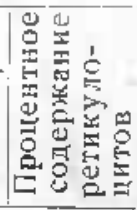 \\
\hline & Дворняжка (желт) & 5,5 & & 32 & 5 & 5 , & & 5,8 & 0,95 & 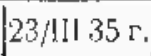 & 16 дมей & 48,2 & $2,32,0$ & $0 \mid 16,0$ & & 8,3 & $2, \mathrm{I}$ \\
\hline 2 & Сеттер гордо1: . . & 16,9 & $8 ; 1$ & 33,5 & $27,5 \mid$ & 6,0 & 5200000 & 5,4 & 0,1 & $29 / 1 \vee 35$ & 21 , & 45,2 & 230,1 & $\mid 15,1$ & 6500000 & $6,9^{\prime}$ & 0,32 \\
\hline 3 & Дворияжке (рыжs.). & 6,3 & $15 i$ & 40,5 & 34,4 & 6,1 & $68: 0000$ & 5,9 & $0,9] 8$ & $3 / \mathrm{V} 36$ & 18 & 48,2 & 231,0 & 14,0 & 0 & 6.7 & 4,1 \\
\hline 4 & Дворняж.(Шарик) & 17,0 & 15 & 32,2 & 28,0 & 4,25 & 54 & 5,9 & 0,18 & 15 & 30 & 39,0 & 9,0 & $15,0^{3}$ & & 6,9 & 1,1 \\
\hline 5 & Дворнякижа (Уран) & 18,0 & & $3 \overrightarrow{3}, 0$ & $0_{1}^{\prime}$ & 5,0 & 62 & 5,6 & 0,75 & $18 / 1 V 36$ & 16 & 40,1 & 25,7 & 14,4 & 60 & 6,6 & 0.65 \\
\hline 6 & Дворняжка (палая) & 10,0 & & $2 ?$ & & 5,3 & 65 & 4,5 & 0,2 & $17 / 11136$ & $10 "$ & 32,5 & 18,1 & 14,4 & ris 5 & 5,0 & 0,2 \\
\hline 7 & Пворияжка (черн.) & 9,5 & 181 & 29 & 22,3 & 7,2 & 5800000 & 5,9 & 0,98 & $5 / I \vee 36$ & 17 & 37,5 & 20,6 & 16,9 & 616 & 6,2 & 2,0 \\
\hline 8 & Дворняжка (рыж.). & 7,0 & $7 / N 36$ & 30,0 & 23,0 & 7,0 & 4700000 & 6,3 & 0,4 & $28 / V 36$ & 21 & 32,3 & 15,1 & 17,2 & 48 & 6,7 & 0,38 \\
\hline 9 & Такса . . . . & 4,0 & 1/IV 36 & 23,5 & 18,0 & 5,5 & 5000600 & 4.7 & 0.99 & $36 n$ & 19 & 25,0 & 11,5 & 13,5 & 0 & 4,9 & 2,4 \\
\hline & Дворняжия (черн.) & 4,5 & $7 / \mathrm{V}] 30$ & 22,0 & 20,0 & 2,0 & 4204000 & 5.1 & 1,2 & 6 & 21 & 35,0 & 20,0 & 15,0 & 00 & $7,-:$ & 1,9 \\
\hline & Собака № 12 . & 10,0 & $\ldots$ & 1500 & 48,5 & 1,5 & 62 & 8 & $m$ & - & $17 n$ & 52,5 & 35,0 & 17,5 & 540 & 8,2 & - \\
\hline & M IIC . . & - & - & 42,5 & 35,0 & 7,5 & 6 & 6,9 & 一 & 一 & 20 & 51,0 & 23,3 & 17,7 & 62 & 8,2 & $\rightarrow$ \\
\hline & Лаверак . . . & $|16,0|$ & $2: 1136$ & 3 &, 5 & 7,0 & 610 & 6,3 & $0, ?$ & $15 / 1136$ & 13 & 45,1 & 28,5 & 16,6 & 6 & 6,9 & 2,37 \\
\hline & Дворняжка (рыжі). & 13,5 & $10 / 1136$ & 29 & 24,3 & 5,5 & 5100000 & 5,8 & 0,985 & $22 / 1136$ & 12 & 38,3 & 20,1 & & 58 & 6,6 & 1,9 \\
\hline & Такса № 2. & 8,0 & $4 ;$ & 35 & 31,8 & 3,6 & 6 & 5,9 & 0,35 & 2 /III 36 & 25, & 40,1 & & & 6100 & 6,9 & 0,31 \\
\hline & IIInka $\pi$ & 9,3 & 10 & 39 & 31,2 & 5,4 & $6200: 00$ & 6,3 & нензв. & 1/LV $36^{n}$ & 20 & 42,3 & 25,4 & 16,9 & 70 & 6,0 & неизв. \\
\hline & ІІппиц ... . & 7,1 & $5 /$ V 36 & 50,1 & $|49,0|$ & 1,1 & $65(000)$ & 7,6 & 0.21 & 3 VII $36_{v}$ & 28 & 58,3 & & 19,8 & 67 & 8,7 & 0.3 \\
\hline & Средне-ар & $|9,56|$ & 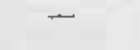 & $|34,5|$ & $|00,0|$ & $|4,5|$ & 5804000 & 6,0 & 0,5 & - & 19 & 41,8 & {$[25,0]$} & $\mid 16,8$ & 6050000 & {$[\overline{6.6}]$} & $1, \overline{18}$ \\
\hline
\end{tabular}


Таблнце 4.

обеледование гпютатиона в норме и при insuf v. tricuspidalis.

\begin{tabular}{|c|c|c|c|c|c|c|c|}
\hline \multirow[b]{2}{*}{ 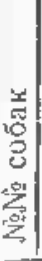 } & \multicolumn{6}{|c|}{ обследовано до наложения порока } & $F$ \\
\hline & 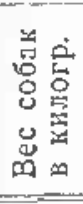 & $\begin{array}{c}\text { Общи й } \\
\text { глютіх } \\
\text { хион }\end{array}$ & $\begin{array}{l}\text { Восста- } \\
\text { 1овлен- } \\
\text { ный } \\
\text { улюта- } \\
\text { тион }\end{array}$ & 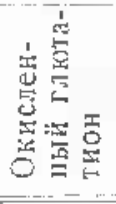 & $\begin{array}{l}\text { Копиче- } \\
\text { ство } \\
\text { эритро- } \\
\text { уитов }\end{array}$ & 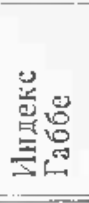 & $\begin{array}{l}\text { Процент- } \\
\text { ное со- } \\
\text { держа- } \\
\text { ние рети- } \\
\text { кулоци- } \\
\text { тов } \\
\end{array}$ \\
\hline $\begin{array}{l}1 \\
2 \\
3 \\
4 \\
5 \\
6 \\
7 \\
8 \\
8\end{array}$ & $\begin{array}{r}20,1 \\
8,5 \\
10,5 \\
9,3 \\
10,8 \\
13,0 \\
8,6 \\
13,1\end{array}$ & $\begin{array}{l}36,5 \\
24,0 \\
32,0 \\
27,9 \\
30,5 \\
21,5 \\
20,5 \\
37,2\end{array}$ & $\begin{array}{l}31,5 \\
19,5 \\
27,1 \\
22,7 \\
24,0 \\
19,0 \\
14,0 \\
30,3\end{array}$ & $\begin{array}{l}5,0 \\
4,5 \\
4,9 \\
5,15 \\
6,5 \\
2,5 \\
6,5 \\
6,9\end{array}$ & $\begin{array}{l}5400000 \\
622001 \\
490.100 \\
520000 \\
4810000 \\
4100010 \\
510000 \\
5200.00\end{array}$ & $\begin{array}{l}6,7 \\
4,0 \\
5,5 \\
5,3 \\
6,3 \\
5,2 \\
4,0 \\
7,1\end{array}$ & $\begin{array}{l}0,5 \\
0,25 \\
0,41 \\
0,67 \\
0,7 \\
0,3 \\
0,5 \\
0,48 \\
\end{array}$ \\
\hline & 11,7 & 28,7 & 23,5 & 5,2 & 5112500 & 5,6 & 0,48 \\
\hline
\end{tabular}

Габлица 4 продолж.

\begin{tabular}{|c|c|c|c|c|c|c|c|}
\hline \multirow[b]{2}{*}{ 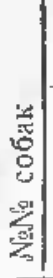 } & \multicolumn{7}{|c|}{ Обследовано } \\
\hline & 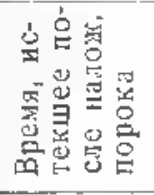 & 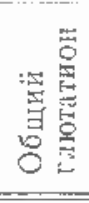 & 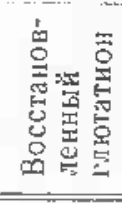 & 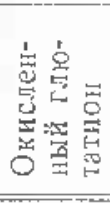 & $\begin{array}{l}\text { Количе- } \\
\text { ство } \\
\text { ритро- } \\
\text { дитов }\end{array}$ & 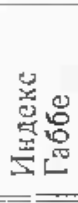 & $\begin{array}{c}\text { Продент- } \\
\text { пое со- } \\
\text { держа- } \\
\text { пие рети- } \\
\text { пулоци- } \\
\text { тов } \\
\end{array}$ \\
\hline 1 & 8 даней & 49,0 & $20, \overline{5}$ & 28,5 & 6180000 & 8.6 & 2,0 \\
\hline 2 & 4 & 58,0 & 10,0 & 48,0 & 72000003 & 5,2 & 0,98 \\
\hline 3 & 12 & 55,0 & 14,0 & 41,0 & 5900000 & 9,3 & 0,7 \\
\hline 4 & 5 & 42,5 & 14,0 & 28,5 & $7251 \div 00$ & 5,9 & 0,72 \\
\hline 5 & 8 & 53,4 & 16,0 & 37.4 & 6250000 & 8.6 & 0,79 \\
\hline 6 & 6 & 49,3 & 13.0 & 36,3 & $52100: 0$ & 8,4 & 0,8 \\
\hline 7 & 9 & 49,3 & 16,0 & 33,3 & 71000100 & 1). 2 & 1,0 \\
\hline 8 & 11 & 64,0 & 40,0 & 24,0 & 7500000 & 8,5 & 1,5 \\
\hline & 8 & 52,6 & 18.0 & 34,6 & 6573750 & 7,5 & 1,06 \\
\hline
\end{tabular}

не сразу, а имеет тенденцио возрастать постепенно. Во всяком случае, в более поздние сроки, после образования порока, дивульфиднап форма глютатиона становилась больше, чем в нацале. Эти данные позволяют нам утверждать, что даже при компенсированных пороках сердца иместся парушение окислительно-восстановительных процессов, и гинертрофия сердечной мышцы не спимает этих нарушений, как должны были бы мы ожидать, исходя из лредставлсний о ее компенсаторном значении.

Что касается ретикулоцитов, то последние возрастаю не сразу, а постеґенио, достигая на $15-16$-й день своего макси- 
мума, на котором остаются с незнацительны. колебаниями в течение всего заболевания.

У собак второй групиы мы также обследовали фракции глжтатиона до и лосле наложения порока правого сердца. Особым зондом (крючкообразным) мы проникали через яремную вену в правое сердще. IІосле внедения зонда в полость вены, чтобы попасть в полость правого сердца, приходилось отводить зонд несколько латерально от серединной линии шеи и, слегка ириподняв его нверх, осторожно ироталкивать вперед. При этих условиях зонд попадал в полость правого сердца, причем ощущалась мышечная стенка сердца. Оставленный в таком положении зонд при сокрашении сердца выталкинался обратно. После этого мы коротким рывком выдергивали зонд для того, чтобы имезоџимся на нем крючком с лезнием нарушить целость трикуспидального клынан. Показателем разрыва қлапанов служило появление лоложительного венного пульса и систолического шума, правда, не всегда прослушиваемого, несмотря на разрыв кงапана.

Таблица 5.

Тлблицан 6.
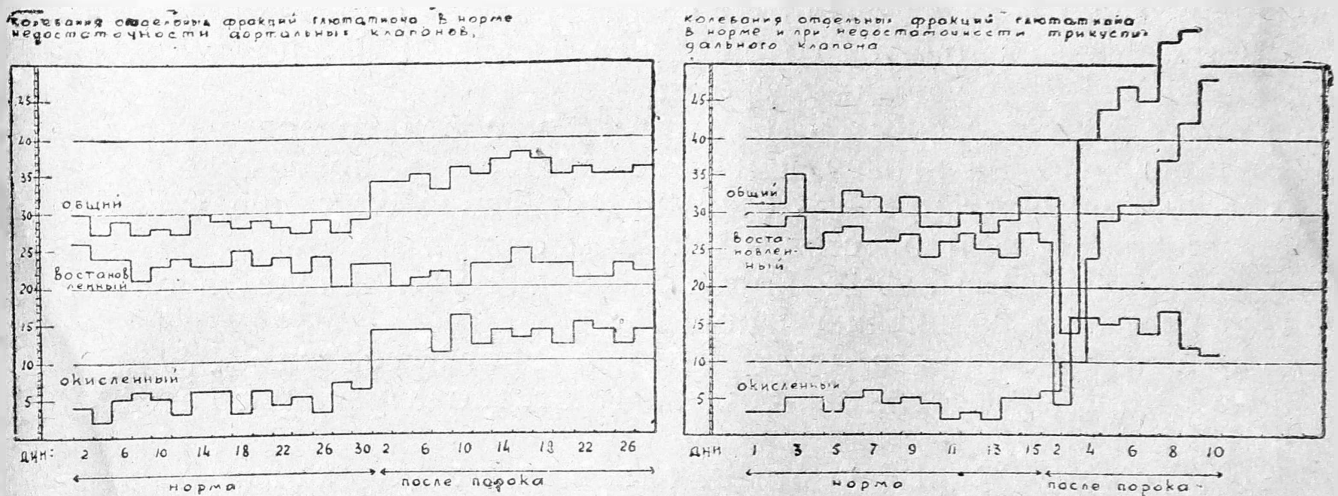

Обследование фракций глютатиона при трикуспидальном пороке в первые два дня показало резкое снижение обцего глютатиона (таблица 5 и 6) и увеличение окисленного. Начиная примерно с 3-4-го дня общий глютатион, как правило, давал резкий скачок вверх, восстановленный-резко снижался; окисленный глютатион по сравнению с исходным повышался в 7-. 8 раз. Резкое расхождение между общим и восстановленным I'лотатионом показывает серьезное нарушение окислительновосстановительных цроцессов при правых пороках серлца. При правых пороках сердца ретккулоцитоз настуцал раныше и й: вал резче выражен, чем при аортальньх пороках, и имел тенденцию к дальнейему увеличению.

Анализируя результаты, установленные при зкспериментальных пороках правого и левого сердца, следует указать на оспбенности и разницу в окислительно-восстановительных процессах, связанных с колебаниями глютатиона при этих видах кардиоп Т พй. 
При левых пороках обпий глютатион повышается медлепно, достигая своего максимума в более поздние сроки. При правых пороках в начальной стадин порока, в первые три дня, общий глютатион дает резкое снижение по сранению с нормой и затем, как иравило, нарастает го сравнению с нормой примерно п полтора раза, проввля тенденцию к дальнейшему повышенито. Нарастапие общего тиятатиона при иравых пороках, в отлиние от этол процесса при певых пороках, имет скачкообразный харақтер.

Восстаноленный глютатион при левьх пороках снижается незначитсльо, при граных пороках имеет место резкое сго снижепие. Окисленная фракция глютатиона при правых пороках сердия рсзко нарастаст, при левых пороках сердца нарастает незначительно. Сдвию ретикулоцитов в сторону увеличения при правых н левых пороках сердцат указывает на связы этого вида пороков сердца с эритроноэтинеской системон в сынде стимулирования ее функций.

Нужно отметить, что паблюдаемй ири правых пороках сердца ретикулоцитоз щроисходит в ранней стадии порока и Ілавным образом за счет 4-й групп, ретикулоцитон. ГІри левых пороках ретикулоцитоз совершается за счет 1 и 2-й групп и отмечастся в более поздние срокн.

В свете этих даниых нам кажетсл, что в патогенезе кардиопатин глютатион играет немаловажную роль, поэтому опреде. ление его ножет пролить свет на состояние окислительо-восстановителыных пропессов в больном организме.

Bыводы: 1. Гри левых пороках серлца увеличивается общий r. ютатион по сравнению с нормой:

а) в порме общего глютатнона в крови собаки $34 \% \frac{1}{2} \mathrm{м} \%$, после порока содержание обпего глютатиона увеличивается до $41,8 \mathrm{~m} \%$

b) восстановленный глютатион при этих пороках сердца падает по сравнению с нормой; нормальге содержание восстановленного глютатиона $30 \mathrm{~m} \%$, после норога- $25 \mathrm{~m}^{\%} \%$;

c) окисленный глютатион крови увсличивастся при пороках с аортальной недостаточностыо по сравненио с нормой: норма 4,5 мг\%; после порока- $16,8 \mathrm{~m} \mathrm{r}^{0} \%$.

2. При нравых пороках сердца:

a) общин глютатион крови увеличивается по сравнению с нормой; норма $32,7 \mathrm{mr} / 0$, после порока- $52,6 \mathrm{мг \%} \%$

b) восстановленный глютатион қрови падает при этих порожах по сранненио с нормой; норма $27 \frac{1}{2} \mathrm{mr}^{\circ} \%$, пюсле порока$18 \mathrm{M}^{2} / 0$;

c) окисленный глютатион увелицивается по сравнению с нормoй. Норма $5,2 \mathrm{~m}^{0} \%$, nucлe mopoka $34,6 \mathrm{мг} \%$. 
Из бактериологического огделения Саратовской городской санитарно-бактериоэотическй лаборатории (зав, лябораторисй И. А. Голидштейн).

\section{Случай септического заболевания, вызванного b. Proteus.}

\section{В. С Петерсон и Б. К. Рубашкина.}

В вогросе о натогенности b. Proteus нет достаточнсй ясности. Большинство авторов считает іротея условно патогенным видом. Однако векду широкого распространенкя b. Proteus в природе и слособлости его залушать на средах рост других нидов щриходитси с болынй осторожностью подходить к признанию его этиологического значения в каждом отдельном случае. Указания па протея, как на возбудителя мсстных заболевании, встрегантся в литературе не так редко. Хаузср в 1882 г. описал случай флегмонозного воспаления, при котором возбудителем был b. Proteus и стрелтококк. Бердников в руководстве проф. Златогорова указынаєт, что протей был найлен в патологичском матсриалепри кишечных расстройствах, отравлениях, перитонитах, циститах, пиэлонефритах, параметритах,отитах, мезингитах, абсцессах мозга. Mr встретили в литературе также несколько случаев нахождения b. Proteus при гнойных плевритах (Паули, ІШаре, Медведева).

Соббщения о достоверных случая обцих протеусних забоженаний встречаются редко. В доступной литературе пам удалось пайти следуюшие даные. Нохманн описал общее заболевание на почве гнойного мастоиджта. Посев был сделан в момент наивғсшсто подьема температуры $\left(40^{\circ}\right)$. Через 10 часов выросли в громадном количестве в. Proteus и 30 колоний стрептококка. Бертельсман и Мау описали случай уретральной лихоралки, при которой из крови выделен протей. Ленхартц описал случай гнойного перитонита, при котором агаровые культуры кз крови и гноя брюигны дали чистую культуру b. Proteus (трн ıоследних работы цит. по Клинебергеру Z-sch. f. Нуg. l908, т. XXVIll).

Гeбes (Deutsche Arch. f. klin. Med., 1914) оиисал случай менингита у новорожденного, при котором из сиинно-мозговой жидкостн и из крови был выделен b. Proteus. Кровь была взята из пальца в день смерти. Паули (Münch. med. Wochenschrift, 1917, № 1-2) описал случай огнестрельного ранения с перслоnом бедра. Из вонючего гноя раны бым выделен протей. Через день после операцин, сопровожданшейся выскабливанием полости острой ложечкой, развился энойнғй плеврит. В гное нз плевры был тажже найден b. Proteus. Aвтор считает метастатический занос инфекции по кровяному руслу несомненным. Оэрицательный результат посева крови он об̆ъясняет тем, что 
посев би, сделан через 3 недели посте наияысшего развития цнфекции, шри нормальной темлературе.

В определителе микробов Бердже (Кнев, 1936) упоминается о нахогках протея в крови, описанных Ассис (тифонодобнос заболевание) и Пачеко (легочный абсцесс).

Веиду скудности лнтературных данных ио этому вопросу, мы считаен нелишикы описать случай обпего заболевания, при котором роль і. Proteus, по нашему мнения, является несонененй.

Нами 11роизводились только бактериологические исследования. Клиниеского течения болезни мпие наблідали, а с нсй познакомичись из истории болезни, лобезно прелостанленной нам проф. linkoлаевцы (клиника уха, горла и носа Сар. мсдинститута).

Џольная O-ва, 45 лет, подвергалась операции по поподу тюйного воспатения

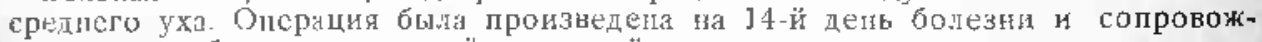
далась выскабливаннем острой эожечкой некрогизированых ді издаюших тругный запах частей костн.

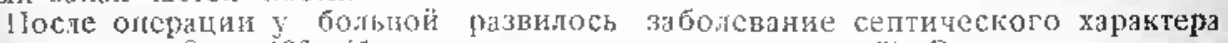
с подлемом то ло 40 (больная страдала также малярией). Рана имепа селтический вид и выделяла вонючий гњой.

На 20-й день поспе операцин появися метастаз иод подбородком. Через 2 жесяца после оперзцин болыня понила при явлспия со стороны нервной снстемы. fla искрыти был обнаружен абсдесе в области левой затнлочной มू०.11.

В течение болезии произиодиниси посевы крови, тноя из уха, из метастаза, э также станилась алтиятиация выделенных культур с сывороткой бо:ьной. І7осев крови (иа сахарный бульон, с лоследуючим высевом иа кровяной н простой агар) был произведен дважды-на 4-й и 9-й пель посяе операции. В обоих слуая была выделена одна н та же культура, хотя подробно изунена была лишь вторая нз пит, т. к. первын раз было залодозрено загрязиение.

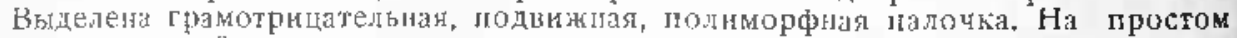
ауаре-ползуий рост, па кровяном-зеленовато-серые колонин, дающие гемолиз. На среде Эпло-беспветные колонии, давшис сіустя несколько аней дочерние колонии, Кугьура сбражинала глюкозу и галактозу с образованием кислоты и газа, па тевулезе давала кислоту лишь на пятый день, лактозы, мальтозь, манията и сахарозњ пе изменяла. Молоко купьтура пептонизировала без свергывания, желатипу разжнжала, индола не дғвала, питраты восстанавливала до нитритов. Реакдия иа сероводовород-положите:іна. Резкияя Вогес-

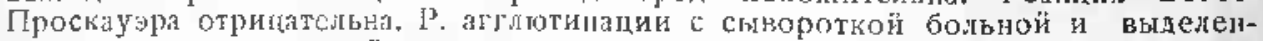
ной из крови кұльтрой дапа положительный на 2 креста резуыьтат в разведения $3: 10,2$

Исследование гпоя из уха дало спедуюпий результат:

Б мазке преобладает грамотрицлтельная иалоцка. Встречаются грамлоложительные кокки. Посев на кровяной и лростой агар дал почти тистую культуру трамотрицательной патоки и редкне колония стафинококка. Стрептококк отсутствова. Купьура оказалась 10 биохимической характеристике идентиной с культурой, выделенной кз крови, за иск-лючением гемолиза, который отсутствовая. Культура агллютинировалась сывороткой больной в разведении 1:100.

Гной из метастази дал следуюшее:

ірреоб̆дает грамотицлтельная галочка. Встречаются грамположительные кокки. Результаты бактериологического исследовация в томности те же, что и лри посеве гноя из уха. Однако культура нз метастаза, так же как и культура нз крови, давала гемолиз, чем только и отличалась от культуры из первичного очаге. Р. аггпотннации не ставилась, так как сыворотки больной у нас ужс не быто.

Выделеныл нами культуры являются, 110 нашему мнению, протеем. Основные прнзнаки, говоряцие за принадлежность их к роду Proteus, нижеследуюшие: 1) полиморфизм, 2) подвиж- 
:ость, 3) ползучесть роста, 4) образование дочерних коложий, 5) протеолитические свойства, выраженные на желатине м молоке.

Культуры в тоцности не соответствуют ни одному из видов, приведенных у Бердже. Ближе всех они стоят к виду Proteus americanus. Однако наши культуры отличаются от указанного вида отсутствием свертывания молока, отношением к левулезе и галактозе и отрицательной реакцией Вогес-Проскауэра. Близко стоят они также к виду Proteus mirabilis, от которого отличаются отношением к сахарозе и частично к левулезе. Таким образом, если принимать во внимание второстепенные признаки, мы могли бы признать их новым, 14-м видом протея. Однако целесообразнес считать наши культуры вариантом одного из названных видов.

$\mathbb{C}$ вой ств выделенных культур и близких к ним видов рода proteus.

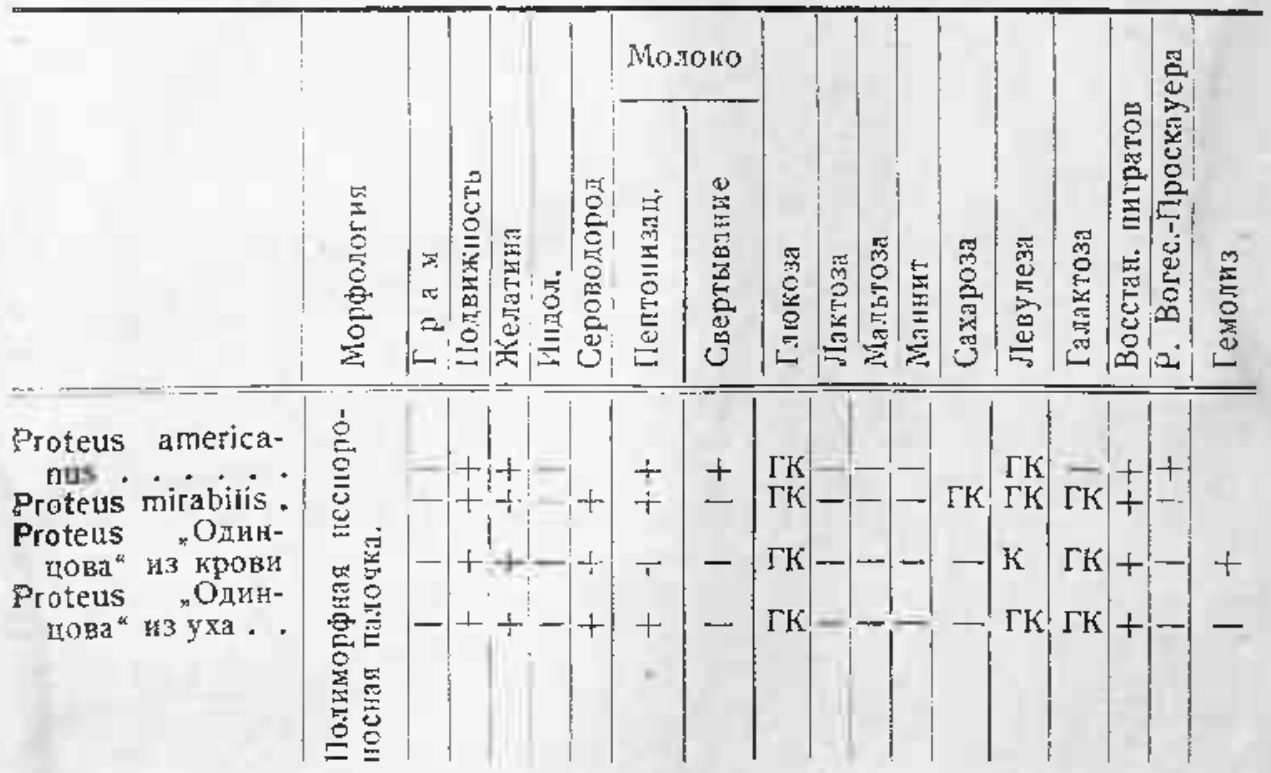

Особенности нашего случая: 1) Повторное выделение культуры из крови в разгаре болезни (задолго до смерти).

2) Ясно выраженная (на 2 креста) реакция агглютинаци нашей культуры с гомологичной сывороткой в разведении 1:100.

По литературным данным такой титр может считаться доказательным. IIo Клинебергеру Proteus vulgaris и mirabilis не атглютинируются нормальной человеческой сывороткой в разведении выше, чем 1:20. В случае протеусного менингита, описанном Гебелем, титр агглютинация культуры с гомологичной сывороткой был 1:60. Однако ввиду того, что Тюмякова и Попона (ненапечатанная еце работа) встречали штаммы b. Proteus, агглютинировавшиеся нормальной сывороткой до титра I:100, мы проверили свон культуры на ряде нормальных сывороток. 
Две дали агглотинацик (на 1 крест) п разведении 1:40, две 1:20 и 38 съвороток агглютинации не дали.

3) Гемолиз, который наблюдался в культурах, выделенных из крови и нетастаза, и отсутстновал в культуре из первиного очага, не ирошедшей через ток крони.

4) Илентинность во всех отношениях, кроме гемолиза культур, выделенных из крови, метастаза и первиного очага.

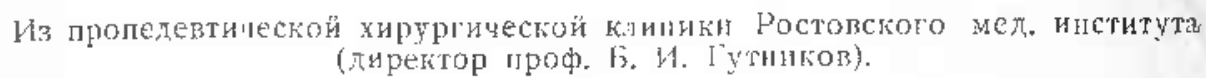

\section{0 кормлении больных при гастростомии.}

\section{B. A. Mákаренко.}

В целях ращионального питагия большых необходимо предоставить орлапизму достаточное количество пини строго определенного состава (белков и жиров животных и растительных, углеводов, солей) и в то же время нужно заботиться о достаточной даче витаминов, так ћак отсутствие последних ведет к ряду харантерних төжельд расстройств в организие. Роже считает, что больние во время болезни расходуют все свои запасы витаминов, и если с пищей они не получают их в достаточном количестве, заболеватот апемией авитамипозного порядка. В силу зтого при назгачении питания приходится, помимо характера заболевания, стелени болезии и стадии его развития, ущитывать и лечебпую сторону питания, его вид и форму.

В этой краткой статье мы пе ставим себе задачей осветить этот большой, сложный и чрезицчайно важный вопрос в целом.

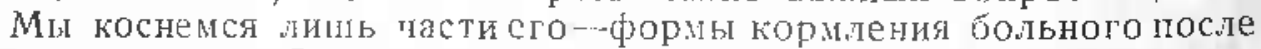
гастростомии. Здесь п большинстве случаев мп имеем перед. собой истощенных больных, оперированных по поводу негроходимости пищевода: рак, руб́цные сужения после ожогов кислотами и пцелогани, ллитсльне спастические сокращения пицевода. Обнцно питнис при свище по Витцело, Гадеру или Гопроверу исключитсльное жидкое (т. к. через трубку невозможно ввести ничего другого) и олнообразное: в основном бульон, молоко, яйца, масло, сахар.

Считая такое питание нелостаточным н неполноценым для Подобных больных, мы задались цельо создать им условия, при которых они могли бы, как и больные, у которых не выключен жевалельный и пишепроводнын̆ аппарат, лолучить разнообразый ассортимент питателығых веществ в форме рациопально приготовленных блюд. ГІоставленпуг задачу мы разрешили путем нспользования 100-граммового шприца с наконечником широкого диаметра. У болыны, оперированных по Топроверу, свип герметичеи, имеет трубку достаточного диаметра. Мы считаем, что для введения пищи может быть использован 
пприц любой системь, необходимо лишь, чтобы длина наконечника была достаточной: 5-8 cм (т. е. с учетом толпины передней стенки живота) и чтобы диаер просвета наконечника нмел 8-10 мм. При этих условиях можно без труда вводить тестообразную массу пици в желулок. Всякая пица-ливернаяк колбаса, паровая или жарегая млсная котлета, овощное, картофельное, яблоцное пlоре, сухари, каши, применялтся в иротертом нли_измельченном виде.

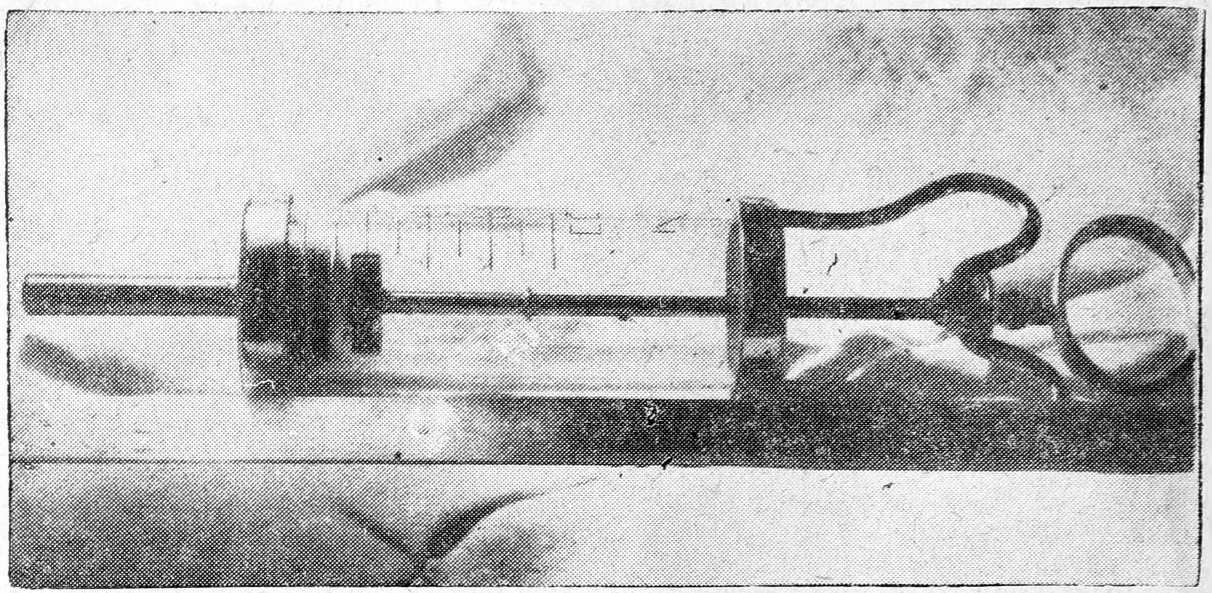

Блюда накладываются в иприц в теплом виде с добавлением сливочного масла, бульона, иолока, т. е. в кашицеобразном виде, как бц пережеванная. Больной получает в рот небольшую порцию этого же, или особо им любнмого блюда для жевания, чтобы создать полное впечатление нормального кормления. Проглатывать пину ему запрещается. Затем наконечник штрица, смазанный вазелином, вставляется в отверстие свицца; блюдо давлением норшня шприца проталкивается в желудок в нужном количестве. Количество пици и часы кормления назначаются врачом в зависимости от случая.

При таком способе кормления больные получают достаточное количество пици и надлежащего качества, независимо даже от их апнетита, и могут быстро восстанавливать потерннное равновесие в питании. ГІредлагаемый сıособ́ кормления больных после гастростомии иы с успехом применяем в клинике c $1936 \mathrm{~F}$. 
$\$ 13$ клиники нервных болезней (директор проф. Б. Н. Маиьковский) Киевского наститута усовершенствования врачей (директор Т. К. Катицкий).

\section{К клинике травм спинного мозга.}

\section{Доцснт Р. Я. Будияа и д-р М. В. Гольдельман.}

\section{Грн изучении клиники травм спинного мозга мы наблюдали одного больного, своеобразие патологин которого заставило} нас выделить и описать его отдельно.

Больной 9,2 , 2 ., рабочий, посгупил в клинику $1 / 1$ 1936 г. с жлдобами на

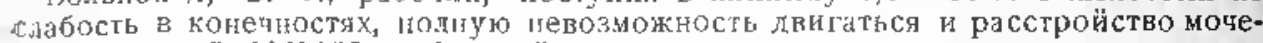
испускания, 2/VII !93; г. больнй во время кугания прыгнул с дерева в воду (с высоты в 4 метра) и ударился головон о канен на дне реки. Больной был жзвлечен из воды в бессозпатениом состоннии и каретой скорой помощи доставлен в Октябрьскую больнцу. Первые шесть дней сознание к больному не возвращалосы; liосле этого в теление полутора мғсялев болыной был в тяжелом состониии, не двигал конечностями, 4ерез 21/2 месяца без заметного улучшения был перенелеп в Психоневрологнческий институт, а затем в первую қлинку КИУВ. Родился здоровым, в летстве rеренес корь, қоклюш. Наследственной отягопенностн не отмечает, курит, пьет мало. Венболезяи отрицает.

Больной выше среднего роста, удовлетворительного питания. Со стороны черепно-мозтовых нервов укионений от нормы не обнаружено. Больной все время лежит. В верхних конечностях сохрннешы лишь ограниеныые движения в кистах. В левой nоле отмечағся отдельғые движения в пальцах и коленном суставе, в шраной ногс движелня отсутсвуют. Сухожильные рефлексы на верхзих копеностя умереные, рлвномерные. "Феноиены Майера и Лери-положительные с лвух сторон. На лижних копеностях рефлекся повышены $S>0$. Қлонус обеих стоп и коленных чашек $\supset$ D. Двустороний феномен Б̈абииского м Оппенгейма. Резко вырэженный фспомен Мари-Фуа с двух сторон. Брюшные рефлексы отсутствуют, Мышцы верхнил конечиостей дриблы, гилотоничны. Нмеется ясно выриженная атрофия в левом m. hуроthмnаг и $\mathrm{m}$. m. interossei с двух сторон, Со сгороны тувствительнои сферы -гинғстезия слева оr $\mathrm{D}_{2}$ до

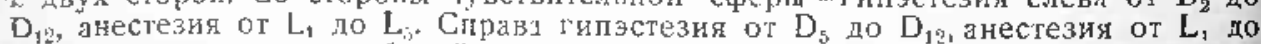
L. Остальныс виды глубокой и поверхноспой тунствительности без изменений. Дермогрзфиз быстро возникает, ярко розовый, сгойкий, равномерный с двух скорон. I1йомоторные рефлексы умереныңе, рлвномерные; мышемный валик выражен больше слева, Ашнер-минс единица, дыхание 23 в одыу ми. нуту; болевыс толки (по Маркесову) нерезко вырыжены. Спинномозговая жидкость (i1) $\mathrm{cm}^{3}$ ) бесивегная, прозрачная, белка $0,2 \%$. Лимфоцитов 7 в 1 мм $^{3}$, јеакция Нонге-Алельта -отрицательная; RW и реак. Кана в крови отрицатель-

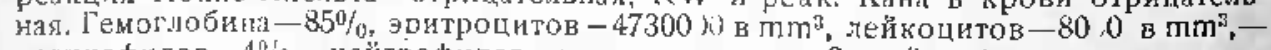
эозинофнлов $-4^{\eta} \%$, нейтрофнлов талочковидылх -8 , лейтрофилов сегментированих-66, тинфоцитов-І, моноцитов ‥5, анизохромия, РОЭ-24 по Ган-

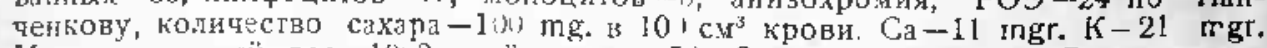
Моча-удетьный вес-10!3, лейколитов 5!) 6 ) в толе зрения. В остальном особых нзшеленй нет. Рентүенография шейной части позвочочника: компрессионны перелом тела 5-10 інейного позвонка и пебольшой подвывих его кзади. Вследсгияе разрушения тела 5+ю шейлого позвонка лейный лордоз превратился в небольшой кифоз.

Во врекл эребывапия болього в клинике в течение 11 дней тсмпература был нормилной; на 12-й ден у больного настулило внезалное повышение температуры до $39,5^{\circ}$, которое повторялось до 5 раз. Эго повышение темпераэуры обычно длилось от IU до 14 часов н резко падало до нормы, а один раз до субнормальной $\mathrm{t}\left(25,8^{2}\right)$. Наше внимание лривлекло пе только своеобразиое повышение темнерауры больного, но и развивавшиеся при этом припадки. Во время этих прападков бользой резко бледнел, сознания не терял, жаловался на затрудненное дыхание. Дыхательные экекурсии резко менялись за счет более ғаубокого и продолжительного вдоха и затрудненного выдоха. Одновременно у 
боль!ого появлялись клонические судороги, резкие боли во всех конечностях и резкое тоническое напряжение мышц живота, ригидность затылка. Припадки сопровождались рвотой, значительной потливостью и нелроизвольным мочеисуусканием. Бледность тица сменялась цианозом. Такое состояние длилось около थаса, после чего настулала общая слабость и соп.

Последующие пригадки бын такого же гига, но в двух случаях поза больного приближалась к опистотопусу; голова подергивалась, в стопах появлялась установка по тиіу філксорпой контрактуры. На высоте припадка мы могли уловить повышение темнературы до 39 , ү, больной был очень беспокоен, кри. тал и задыханся. Отдельные припадки шродолжались до двух часов с некоторыми колебантаяи в свосй нитенсивности. Ввиду угастившихея припадков, больной был переведен в нейрохирургическую кииику для оперативного нмешительства.

Выписка из прогокола огерации 8/1 1937 г. Больғой уложен лицом книзу на подставку Кушинга. Местиая анестезия. Сделана ламинектомия на уровне 4-го, 5-го и 6-го пшейных позвопков. Компресскониый перелом 5-го шейного џозвонка и подвывих его кзади. ІЈо вскрытии duгaе mater выделилось бодьшое количество ирозрачной спингомозговой жищкости Спинғой мозг в этом месте

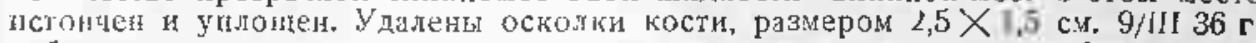
у больного неожиланно наслупито резкое ухудшение, и ол погиб при явлениях гаралича дыхания

Выдернка из прогокола сскция. Труп худого молодого қеловека с глубокими пролежнями на полсниде и на больших вертелах. Сзади на шее рубец, длиною н 20-30 си, дужки 4, 6 шейных позвонков оперативно удалены. Задняя половина 5-го шейного позвонка сменсна кзади в просвег канала приблизительно ја один сантиметр. Канал в этом месте соответственно сужен, а спипной мозг приплюснұтьй и нстонснный. Рнсунок серого вещества сігнного мозга на эоперетных разрезах, выше и пиже места сдавления, достаточно хорошо выявлеп; в белом веществе встречаюге изредка серокрасные мягковатые зелкие пятн1. Головной мозг бледный, 6 вз видимых гнездных изменеиий. Со стороны внутрении органов особых изменений нет.

Таким образом, у нашего больного имела место гипертермия, готорая была связана с припадками клонических и тоннческих судорог при полном отсутствии клинических нарушений со стороны головного мозга.

В настояшее время иместся ряд экспериментальных и клини ческих наблюдений, несомненно устанавливаюпих значение шейного н верхне-грудного отдела спинного мозга в механизме терморегуляции.

Де-мартейль опнсал больного со сшинальной опухолью, у которого после операции темпсратура поднялась до $43^{3} 6 е$ ннфекционного нанала. феера и Вальтғард описали случаи, тде травматическое поражение нижне-шейного отдела спинного мозга привело к картине расстройства терморегуляции. Экспериментально Фрейд и Штрассман, тот же Фрейд и Графе показали, что перерезка у кроликов 6 и 7 шейных сегментов ведет к расстройству терморегуляции. Все эти клинико-экспсриментальные дапные позволили Нахгарту, Фаунгаузеру присоединиться к той точке зрения, что в нижнешейном отделе спинного мозга находятся волокн, имеющие отношение к регуляцин температуры. Некоторыс авторы с помощью измерения кожной температуры пытаются днфференцировать центральную гипертерми о от обычной инфекционной лихорадки. При обыцной лихорадке кожная температура меняется параллельно с внутренней; размица между ними постоянна. При центральных гипертермнях 
разница знацительна, до 2-3 градусов, лричем изменения температуры кожи не следую' за изыенениями внутренней температуры. Гоцобнул диссоцнацио следует обляснить уменьшением теп.тоотдячи кокей, что зависит, вероятно, от одновременного поражения вазоноторного центра, расположенного в промежу точпом мозгу, близко к тепловому пептру. Нижне-шейный отдел спиного мозга имеет также отноление к обмену вешеств, в тастности, к жировону. Погона и Больгов сообщили о 4 случалх поражения слинного мозга (из которых 3 бьли изуцены үнстологически с остро развивнинсл отеком и лоянлениен пузьрей. Авторгі считают, что эти отеки зависели от центральных симпатиеских голокон, идуцих от толовного мозга к вислерильным зффекторным клеткам залнего рога. При этом в разнитии отеков играет роль острота процесса.

Вопрос о локализацин ироцессов терморегулящии в ядрах болыного мозта янлется нанболее трудны. Повынение температуры обнаруживали и ири уколев tuher cinereum (Oфф), corpus striatum (Аронсон и Закс), thalames opticus (Айзеншталт).

Некоторые авторы считают, что процессы терморегуляции осушествляются через tr. spino-thalamicus-thalamus-tuber cinereum. Другие авторы считают corpus striatun высшим тепловыи центpom, a tuber cincreum главныл тернореғуляторон.

У напего больного, кроме выпеуказанной гипертсмни, мы на блюдали лрипадки так назлнаемой „спинальгой элилепсии". Описание подобных прилалков ны очень редко.

Так, Колье онисал один случай: под его наблылением находилась мотодая желицин, которал за несколько месянев до поступления ничяла страдать местными эпилелтичсскими судорогами в пралой ноге и стопе, но без потери сознания. Впоследствии повился спастический парялич праной ноги, который постепенно усиливлсл. В этом случае автор спитал неосиорим ым наличие органического поражения мозга без точной топи-

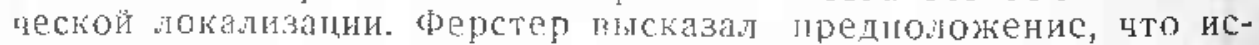
ходной точкой эпиелтического приступа мокет быть любой участок щервной системљ, как центральцой, так и периферической. При всей сложности проблемы элилепсии все же следует исходить из некоторых предпосылок, и в этом отногеник нам какутся приемлемыми следуюшис обпие положения патогенеза и кииники энилелсии: нет такого поражения мозга, которое обладало бы специфическия свойством вызывать эпилепсию, канов бл ни бнл его характер и мссто расположения; $с$ цругой же сторонл, вряд ли суцестуег такое поражение мозй, которое не обладало бы сеойтвом в изнсстнцд условиях вызынать эпилепсио. В вопросе о супцестловяния разлинных клинических форм, об их свгзи и взаимоотнопении друг с другом, нам кажется, заслуживает внимания сравнение, даваемое Кенеди. Автор говорит об, элилептическом слектре“, подчеркимая этим, что в этом спектре есть много цветов, которые незаметно персходят друг в другя. Может быть, где-то в эток пироком 
эпилеттческон спектре мл должны поместить и олисанныи нами случай так называемой "спинальной эпилепсии“.

У нашего больного патологический очаг был $\mathrm{n}$ шейном отделе спинного мозга $\left(\mathrm{C}_{4}-\mathrm{C}_{5}\right)$. Мы полагасм, что здесь имело место нарушение связи сиинного мозга с центральными механизмами теллорегуляции и обмена веществ, что привело к описанной шами гилертеряии и "спинальной әпилетсии".

Из хируртнеского отделени Старо-Челииккой больицы ТАССР.

\section{7 так называемом ",апендикулярном симптомокомплексе" при малярии.}

\section{А. А. Шкляев.}

Апџендицит, являясь наиболес распространенным заболеванием органов брюшной полости и в то же время наиболее „коварным“ заболеванием, при потором кардинальные симттомы принимают всевозможные оттенки, цолжен по црану занимать внимание врача-терапевта, а в особенности хирурга при жалобах больных на боль в жиноте.

Взяв себе строго за правило прислушиваться к малейшим жалобам больных на "боли в животе" и тщательно их исследуя, мы в своей работе встретились с проявлением клинических симптомов, вполне напоминающих острый аппендицит, Мы их назвали аппендикуляріны симптомокомплексом, встречаюшимся довольно часто при наиболее распространенном в нашей местности заболевании - малярии.

Приведу несколько историй болезни:

1. Больной М., 33 лет (ист. б. № 25), поступил 4. 1. 1935 г, в резкими болями

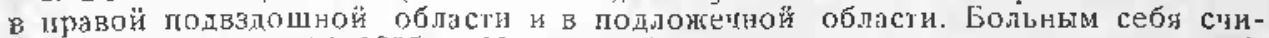
тает с 1 час. утра 4.11935 г. Начало заболевания отмечает резкими схваткообразнымн болями в гравой додвздошной области, рвогой и незначитсльпой головной болью. Темпсратура $38^{\circ}$, пульс-98, удовлетворительног паполнения. Так как в әтот денғ было шазначено несколько операций, то пебрежное исследованис больного, вследствие загруженности врача, привело больного на операционныӟ стол. На олерационном столе после туширования кожи живота иодон-иовторнос исследовапе. Брюшная стенка справа незначительно папряжена, болевые томки М. Бурнея и с париэталинй брюшины. Притуллелие меркуторного звука в полездошной области. „Блюмберг отрицательынй. Диагноз острого аипендицита при соотвегствующем апамнезс и других объективных данных, казалось, бып бесспорным. Разрез по М. Бурнсю. По вскрытии брюшной полости свободно извлсчена соесып без каких-лйо наслоений, слаек и явлений разлражепия брюшного покрова, и совсршенно макроскопически эеизменени й отросток бсз интекии и сосудов с неукороченной и нсутолщенной брыжжейкой, Аппешдектомия. $5 / 1$ самочувстве больюго хорошее. К вечеру газы отошли, що в почь на 6/1 1936 г. (5 цас. уюра) мы были вызваны дежурным цо болынце к больному. Больного застаем в тяжелом состоянии, температура $39,5^{\circ}$, пульс 110, удовлетворительного паполнепия. Жалобы на резкие боли в ране и цод гожсикой. Рвота. Предпринята рсвизия раиы. Края разреза не ицфильтрированы, ранка сухая, инфильтрата и красноты около раны нет. Ввиду резкой раздражительности больного введен подкожно Sol. morphii mur. $1^{0} / 0-$ $1 \mathrm{~cm}^{3}$, мұло уепокоивиий больного. Тмательное исследование больного дало 


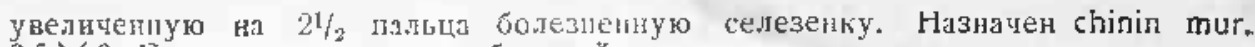
$6,5 \times 3$. Поспе приема хины больной услоколлся, уснуп, рвота прекратилась. н ла вечернсы обходс больной дал совершенно свободно пальпировать живот, аяяляя о полном отсутствии болсй в ране. В далыейцем течении заболевания состояне больоло уловыетворительное. Подъемы температуры регулярно через день, 10'1 сняты швы: Заживление иервичны натяжением. В крови больного обнаружены ппразиты mal. tertian. 11 ' выписап в хоропем состоянин для амбулаторного лечения.

2. ГІочти аналогичная история болезни больной Б. (№ 40), где налимо были все признаки острого аппендицита и где недостаточно добросовестиое исследование больного привело больнуғ на операционный стол. На операции мы нашли макроскопически соверценнонеизмененный отросток, не подававний и намека на бывыее или суцествуопее его воспалепие, а также на присут ствие каловых қамней, даюыцх так называемую „аппендикулярную колику". После дополнительного исследования мы в данном слуцае также нашли увеличеннуг селезенку, и хинизация больной выяснила истинуно картину заб̆олевания.

Подобног рода случаев, но с менее выраженными симптомами, мы можем отметить еце два. Наблюденис приведенных случаев В дальнейшем дало нам возможность избежать практической онибки и распознать паппендикулярный синцтом п пи малярии.

Приведу ряд примеров.

3. Больной M., 27 л. (ист. бол. № 420), поступил в 6ольницу 20/V!ll 1935 г. с жллобой чи језкие боли схваткообразного хирактери в гравой подвздошной области к р подложечной областн, Больным себя считает с 18 VII 1935 г. Заболевание началось резкими болями в тодложсчной области и в правой половине жнвота, разитого характера, 19,111 самочувствие лучше. Боли почти исчезли. Рвота повторно, зиоб, незначительная головная боль. Вид гяжело больного: язык сухой, слегка обложен, алиетнт совершенно ұтрачен. Состояне беспокойное, временами болн в животе. Со стороны внутренних органов отклонения от нормы не опредсляется. Температура $38^{\circ}$ угром, и $39^{\circ}$ к 12 часам дня. Пульс 98, хорошего наполнення. Живот равномерно вздут.

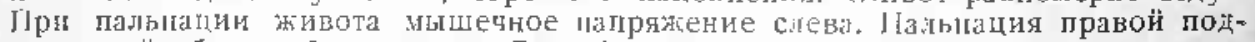
вздонной области болезненна. „Блюмберг“ отрицательный, Поченочияя туиость сохранена. Cелезенка увеличеш па 2 пальца, резко болезненна. Газы ие отходили, стул задержан. Склеры иктеритлы, имеется резко выраженшый супраөрбитальный рефлскс слева. Больному назатен chnin mur. 0,5Х3. Больной к вечеру вспотет, попросил кушать, ночь спал хорошо, ночью же отошли газы и нормальный стиі. Утром 2l/VIIl температура $\mathrm{N}$, пульс 72 , хорошего наполненяя. Живот мягкий, болезпшых зон и точек не онределяется; дальнейшая хинизаци, и на 5-й день больной выписан в хорошем состоянии,

4. Б-ой доставлег в больницу с диғпозом острого алпендицита, Начало заболевания острое. Тенпература $38,5^{4}$, пульс 10), но хорошего налолнения. Жалобы на незичительну боль годовы, разбитость. Все внимание больного сосрелоточено па правой подвздошной области (б́льной держит руку в этой өбласти). При Палъпации detense musculaire orсутствует. ЈІри пальиации в правой подвздошнй области больной резко реагирует, болезненааз точка М. Бурлея, рефлекс с париэтальнов брюшины, дороросовестно обследовав больного, жы налли увеличеную, резко болезненлую селезенку, выстунанщую из-лод. реберной дуги пз 2 иалца. Гененочия тупость сохранена; газы не отходили 2 дня. На основании состояния иульс, отсутствия выраженяого напряжения брюшной стенки, а также увеличеннй и болезпснной селезенки при иаличин левого супраорбитального рефлекса мы от операцик отказались, назначие боль ному chin. muг. 0,5 Х3. Ночью обильный пот, газы отошли, и больной успокоился. Лабораторное исследование крови выявио паличие паразитов малярии. В теченне нелели проводилось противомаяянйное лечение, и больной жалоб: на боли в животе ни разу не предвявлял. 
Описанный -аппендикулярный симптом“ мы провернли на материале более 200 случаев, находя у маляриков в стадик острого приступа следующие признаки:

1. Интенсивная в большей или меньшей степени болезненность в правой подвздошной области, как при пальпапии, так и в известных случая спонтанная.

2) Точка $M$. Бурнея почти всегда ясно положительна.

3) Défense musculaire в зиачительном количестве случаев отсутствует с правой стороны или выражен в очень незначительной степени.

4) Иногда наблюдается задержка газов и стула.

5) Симлтом Блюмберга, как правило, отрицательный.

6) Пульс во всех случаях удовлетворительного наполнения. и, несмотря на частоту, в некоторых случаях не носит абдоминального характера, говоряшего о раздражении брюшины.

В достулной нам отечествепной литературе мы нашли статьл д-ра Демьянова в Кубанском н. м. вестнике, том $V$ за 1936 г. нод заголовком „О малярийном аппендиците“. Вряд ли название „малярийны аппендицит“, правильно: слово appenditis говорит о наличии воспаления отростка, мы же полагаем, что подобные. случаи должны быть отнесены к категории разбираемого нами симптомокомплекса.

B "Вестнике хирургии и пограничных областей за 1928 г., т. XIV, помепена работа О. А. Флерова, где автор приводит данные Брессо о 5 маляриках с диагнозом аппендицита, у которых при операции аппендикс оказался неизмененным (что подтверждено и микроскопически). В зтой же работе приводится цитата Циманна, отметившего аппендицитоподобные явения при малярни.

Bыводы: 1) Своим сообщением мы отнюдь не намерены защицать консервативный метод лечения при остром аппендиците. Будучи принципиальным сторонником раннего оперирования при остром аппендиците, я желаю своим сообщением о так называемом "апнендикулярном симптоме при малярии предостеречь от возможности диагностической ошибки.

2) Так называемый апгендикулярный симптомокомплекс, элементы которого изложены выше, встречается в огромном проценте слупаев при острой малярии и должен быть учтен при постановке диагноза острого аппендицита.

3) Важным подспорьсм в дифференцидыьой диагностике слуе жат исследование крови на паличие паразитов малярии и гемоrрamia.

4) Механизм ироисхождения этих аппендикулярных болей при малярии не выяснен. Мы полагаем, что увеличенная селезенка тянет Lig. gastrolienale, а отсюда полугается раздражение всего plex. solaris. Отраженные боли проявляются именно в подложечной и правой подвздошных областях, у которых имеется между собой какое-то взаимодействие. Между селезенкой и ileo-coecal'ной областью имеется әмбриогенетическая связь, которой, вероятно, и можно объяснить возникновение „апендикулярного симптома“ при малярии. 


\section{Обзоры, рецензии, рефераты и пр.}

\section{Реуензия.}

IIpod). А. Д енкер, піроф. В. Алт брехт. Уиебник болезней

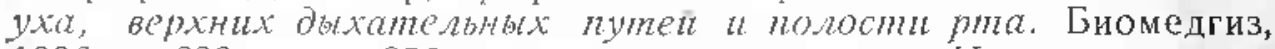
1936 г, 623 стр. с 350 рис. в тексте и атласом. ЦЦена в переплете 16 руб. Перевод с X! немсцжого издания д-ра А. И. Кортужанского под редакцией и с дополнениями доц. Я. Б. Каплана.

Учебник издан на удовлетворительной бумагс, набран отчетлившм шрифтом, богато иллюстрирован рисунками. Представляет собой весьма солидний труд, кратко и в то же время обстоятсльн излагаюций основи оториноларингологии. Предпосылка основ профилактики и терации изложению отдельңых частей, а такжс глява о заболеваниях полости рта и фонетическое приложение, делают учебник особенноценным. Совершенно очевидно, что он получит самое широкое распространение как среди упащихся, так и среди практических специалистов.

Однако отдельные места учебиика не лишены недостатков. Так, налр. отдел об исследовании уха изложен недостаточно полно. Не приведена даже форнула исследования ула, принитая на мекдународном орл Конгресе в 1912 г. Далеко не полностью приведены њетоды опрсделения выносливости вестибу лярного аптарата, примсняемые ири профотборе. Нигде не сделано описания Mеньеровского симитонокомплексы, тогда как сснлки на него встрецантся неоднократно. Совершенно не упоминается об особенностях воспалительных заболеваний ушей, осложненных присутствнем ьас. Plaut - Vincent'a. Физиология носа представляется в настоящее нремя зиачительно шире, дем это приведено в учебнике.

Некоторые положения авторов, частично оговоренные редакэором, не могут быть приниты полностью. На стр. 278 сказано, चто „При первичном склерозе проводить обцце лечение, до известиой степени профилактическое, не рекомендуется". Едва ли кто из нас с этими согласится. Томио так же утверждение, что „только при больших абсцсссах (околомипдаликовых), обэлруживаюпихся ясной флюктуацей, бываст проще вскрыть еғо спереди", не является обцепринятым. Рекомепдуемый авторами, как лучший, способ лечения острых воспалений челюстной пазухи, а ранно и острых гнойньх воспалений среднего уха промываниями требует, нах кажетсл, большой осторожности. Неверно гримечание редактора, что при определении голности к слукбе в РККА следует руководствоваться приказон РBC CCCP № 111 or 1931 г.

F заключение следует дысказать сожалсние, что некоторые рисунки получились недостаточно отчетливы, а цветные таблицы приложсны отдсльно. Все эти мелкие замечания должны быть уютенн лри следуюшем издании.

В. Громов. 


\section{Рефераты.}

\section{а) Иммунология}

$\mathrm{G} \mathrm{r}$ as s e t, E. et Le w in, W. Роль и знаиение антигена брюино-тиярозных zитаммов винбекиии, тммунитете, а также в полуиениа брғшно-тияозного энdo-анатоксина. (Comptes Rendus des Seances de la Societê de Hislogie, t. CXXIV. 숭 4, 1937, стр. 331). Автор подтверждает положение феликса о взаимной зависимости вирулентности, иммуногенных свойств брюшно-тифозных Штаммов и об инагГлютинабильности их.

Изучениз были подвергнуты тилизированиые штаммы Ту, и Watson, а также выделенные автором штамы Ту․ $7753 / 36,811,8 / 25$. Для контрольных исследований был использован штамм ७э. Рядом собственных наблюдений автор установил полную идентингость иммуногенных свойств вакцины, приготовленной из убитых нагреванием при $58^{\circ}$ инагглюгинабильных штамыов и эндо-анатоксина, полученноғо автором из тех же нітаммов. При этом отмечаетси отсутствие Vі-антител в снворотках. как вакцинированных мышей, так и кроликов иммунизированных әндо-анатоксином, независимо от того, ислользованы ли для приготовления анатоксина убитые при $58^{\circ}$ или живые микробы. О- и Н-антитела в таких сыворотках были обнаружены. Автор считует это подтверждением положения $\Phi$ ел и к с а о термолабнльности и нестойкости Vі-антигена.

Касалсь вопроса шрироды антигеня-Vi, автор счнтает, что вирулентность инаг глютинабильных штамнов брюшного тифа длля мышей зависит также и от токсияеских свойств, присугцих инагглютинабильным штаммам; автор предлагает поэтому аитиген-Vi характеризовать не как фактор лишь вирулентности, а как антиген, определяющий патогенность микроба, слагаюейся из вирулентных и токсинскких свойств

Последнее заключение автор осюовывает на пабюдениях, свидетельствующих, что үибель подолытыл мышей не является результатом сепсисл. Наоборот, опыты, цроделанные автором, показали, что из крови мышей, зараженных внутрибрюиинно авирулештым штаммом $0_{901}$, высеивллось огромное количество колопий, в то время как при заражении вирулентными штаммами из крови мышей высеивались лишь единнчные колония. Во внутрибрғшинном же эксудате находнлось большое количество микробов как в случаях заражепия вирудејтными, так и невирулегтными штаммами.

На основании полученных дапых автор приходит к следующим выводам: 1) наличие аптигена-Vi в брюшно-тифозном шгамые харақтеризуется 3 признаками: О-инагглютина6ильюостью, высокой патогенностью и иммуногенностью штамма.

2) Гоксический фактор играет важную роль в патогенности Vіштаммов бркшного тиф:.

3) Формализованный эндотоксин при своей атоксичности сохраняет подностью иммуногенные свойств:, шрисушие инагглютинбильным штамым, из которых этот эндотоксин получен.

А. Рубановский (Харьков).

$\mathrm{B}$ a $\mathrm{chm}$ is $\mathrm{n}$. А. Значение антигена-Vi в предохранительних свийствах пропивобрюинопияқозиой сыворопки". (Comptes Rendus des S. de la S. de Biologie, t. CXXIV, № 4, 193 , р. 280). На основании собстьенных олытов автор приходит к выводу, что превентивное дейстиие брюшнотифозных сывороток не зависит от наличия в них аГгыютинилов нли цреципитинов, но является результатом действия содержащихся в них олсонизируюших субстанций.

Из 66 мыней, полвергиутых олыту шассивной иммунизации агглютинирующей брющнотифозной сынороткой, лри контролъном заражении вирулентным тифозным чштаммом потибло $56 \%$ в то врсмя как при иммунизации адсорбированой сывороткой, Лпшецной О- и Н-антител, при тех жс устовиях опыта погибло мынсй лишк 2ю\% Иммуиитет длися лри этом 2-3 нсдели. Эффект предохранительнго действия олинаков, независимо от того, содержали ли полученные автором сыворотки Vі-антитела или были лишены таковых.

Легебное же действие адсорбированных сывороток значительно слабее, чем сывороток не адсорбированных.

Автор разлитает 3 тнпа опсонизирующих субстандйі:

1) Субстанци, проявляюшие опсолизируюшсе действие независимо от компле- 
мента и содержащаяся как в сыворотках, имеющих Vi-антитела, так и лишенных нx.

2) Субстанции, носителями которых являются лишь антил Vi сыворотки, проявляющие олсонизирующее действие при отсутствии компіемелта н усиливающие его при наличии комгыемента.

3) Субстанци. действующие в незнацительных колигествах (0,00005' в присутствни комплемента, но проявянщие свое действие независимо от $\mathrm{Vi}$ антител.

Подтвержденне своих выводов автор находит в тех работах $\Phi$ еликса и II итта, из которых следует, что сыворотки, қолученные имму низацией фор-

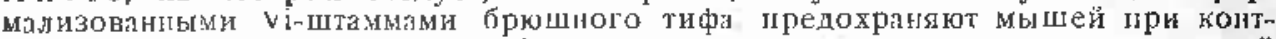
рольном заражении гораздо слабее, чем сыворотки, лолученныс иммунизацией живыми штаммами, несмотря на то, что титр Vілитител в этих сыворотках одинаков.

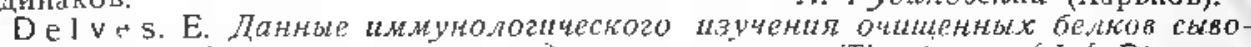
ропки, как обоснование теорит о еduнсmве aнmimeл. (The Journ of Inf. Diseases. vol. 6(!, 1937). В последние с ды появилось много рабор, подтверждающих теорию Ци нссера и у эл тса о единстве антітен. В свеге этих работ становится очевндым, что разрешение проблемы о сдилсте или множестве алтител может быть достигнуто лишь при применении антисыворотки, полученной внелением очищелного антијена вместо бактерий, эритрогитов или цельной сыворотки. Варьируя в этих условиях физичсское состояние антигена и испытывая гомологичные антисыворотки, жожно изучить различные реакции анигена с антителом (предилитцию, агглютиндцию связывџиие комллемента, фагоцитоз). Так как эти реакции могли бы быть существлены преципитируюшсй антисынорогкой, полуренной в результате иммунизчции отиценным антигеном, и так как предипитины удалены спелифической адсорбцисй, то, по мнению автора, изученне влияния т кой адсорбции па юличие других релкций антитела с аптигеном должно иметь большое значсние для докизательства правияыности той или ॠной тсории происхождения аштител.

В своих опытах автор заменил антисн двумя опищеными белкоными фракпияни сыворогки человека-- альбумином и псендогыобулином. Последияс приготовлялис по методу Гежтона и у ли ера, применялсь в $10 \%$ растворе в $1,85^{\prime} / \mathrm{NaCl}$ и сохранялись с толуолом. Частицы коллодия дия реакций готовились по методу Јё̈ а.

Опыты показали, что агглютипация и фагоцитоз коллодй̈ных тастиц, покрытых очицешным альбумином и псевдоглобулином человскя, а также реакция связывания коплемсита этими антгеияи в р с горе, могут быть получены при помощи гомологичной преципитирующсй ашти-сыворотки.

Когда преципитины падело удалены адсорбиией гомологичным антигеном, агглютинины и опсоннны совершенно не обнаруживаются.

Автор спитет, џто эти результ ты служат ирямым доқазательством того, что релкии жежду ашггеном и антителоя, проявляюицеся в внде аггиютиации, преципитлиии, связывани комплеменга и фиксации олсонинов, должын рассматривтться как шроявлене еднного антитела, когда последнес образовалось з результате введения очименого антигена.

I. $P$.

Uhle nht h, F. н R emv, E. $K$ aonpocy of anmumenax k yzлesodan. IV coобцение. Опыты с коллондийными адсорбатамн гликогси, рисового крахмала и крахмала ll у п ко в с ко го (Ztschr. f Inımunitatsf, Bł 84, (937) Авторы изутали антигениые свойства углеводов, исхоця из супествуюцего положения, что вы3вать образование антител могут только высикомолекуляріые ведисства. Они полагают, что низкомолекулярыые вещесть, алсорбировалые ији химически связангые с вепрествами высокомолекупяриыми, могут также обладать антигенными свойствами.

Резулғалыты әксперимента однако не подтвердили высказаниой авторами гипотезы. Оказалось. гто изутениые иии углеводы (гликогеп. рисовый крахмал и крахм л Цу лков кого), адсорбированные на чистом колиодии, будучи ввсдены интравенозно или интр перндопелльн кролику, пе вызывают выработки

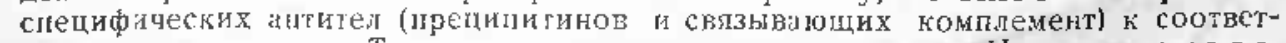
ствующеку углев ду. Только при имиунияции крахмалом II у лковского, употреблятшияся в виде эмулъсии в гумми-арабике и прованском масле, можно. вызвать образование специфических антиел против гумми-арәбика. I. $P$. 


\section{б) Эндокринология}

Stein ach, Kun и $\mathrm{P}$ eczеліk. Aнализ действия полового гормона. (Wieпег klin, Wsch. 2 29, 1936). В одной из свопх последних работ III т е й н ах указал, что кроме непосрелственного полового действия, гормон семенников обладает и несиецифическими влияниями, и в настности особ́уо роль играет гиперемизирующй фактор. Так, через 2 недели после вазолигатуры но Ш те й а ху появляется гишеремия мозга, которая может бын доказана́ методом витальной окраски: после внутрнвенного введения ализариновой синьки нозг животных с вазолигатурой, а также у старых и євнухоидыых животыых вследствие лонижения тонуса сосудов окрашивается несравленно интенсивнее, дем у контрольных. Этим методом авторы пользуюгся для проверки действия химически добытых как мужского, так и желского лолового гормона. В результате этих работ они пришли к следующему выводу: женский половой гормон (ирогинобензоат) дейснует на мужской организм так же, как физиологический инкрет яичек, т. е. получается та Же иитенсивная окраска мозга. Этот эффект не полуцается при введения химичсски полученных мужских гормонов (экстракт из мочи, андростерон, андростандиол, тестостерон).

Далее, авторь пытались установить, обладает ли женский половой гормон наряду с гиперемизируютия действием сиособюость содействовать развитию слсцифических, пснхических функций мужского полового гормона. Для этой цели авторы разработали истод, лозволяющй оцснить степен активности мужского гормона путем определения эролизирования и потецции у кастркрованных крыс самцов. При ломоши этого функционального теста определялось актнвирующес действие женского полового гормона. Окизалось, что при одновременном введении мужского и женского полового гормона колитество первого может быть слинено в $21,-10$ раз по сравнелию с количеством одного только мужского гормона, необходимым для вызыв ния психосексуальной фулкцин. Әто свойство женского лолового гормона авторы объясняют его способностью повышать кровоснабженис и возбудимость центральной нервной системы. Как показали опыты с витальиой окраской мозга, инкрет яичек, т е. физиологический гормон, обладает слособностью вызывать гиперемию мозга. Это свойство отсутствует у исследованыых химичсски добытых препаратов нужского гормона; следовательно, физиологичеккй горион содеужит какой-то фактор, действующий как химнчески добытый женский гормон.

Авторы нытаюся выяснить, откуда этол женский фактор появляется в мужскои организые. После установления выделения эстрогснного вешества в моче у некастрировннных и кастрировинных самцов им некоторое время впрыскивался мужской горнои. Оказалось, џто при этом резко пьвыраезся выделение эстрогенпого вещества, т. е., что женский фактор возникаст путем превращелия из яужского гормона, т. к. ловышение выдслсяия зстрогенного гормопа наб.юдляось и у кастрированных животных; процесс превращения в организе несомненно происходит и вне половых желез. На основе всех этих данных авторы применяли кокбинацию из мужского и жснского гормоное в клинике. Результаты чрезвычы йно обнадежив юцие, в особенности в отношеиия психического лействия, повышения энергии, прекрыпеиия бессонниды и в частности, повышенця потенции Приводится случай импотента, у которого 24 вирыскивания шровирола (м. п. г.) не дали никакого эффекта, а терез тод 19 впрыскиваний комбинацин щровирона с прогиноном (ж) дали полное восстановление потешции.

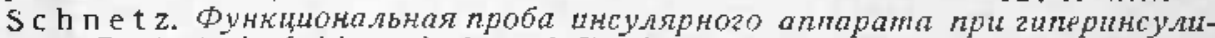
низде. ।Deut. Arch. f. kl. med. dec. 19"6). Состояние гинеринсулинизма по литературным данным последних лет находится в зависимости от печени, нервной системы, одной или лсскольких эाдокринных желез.

Вследствис язвенной болезни желудка или дуоденума, болезни желтымх ходов, резскции желудка и, наконец, чю епе недостаточно изучено, при острых и особеніо хронических ланкреопатиях набюдаюся приступы гипогликемии. В этих случаях гиперфунщция ијсулярного иппарата чәсто вызывает сишдром, ошибочно принимаемый за нстерический или неврастенический.

Автор провел серию опытов над такого рода больными, опрелеляя гликемию натощак, इикемическую кривую с нагрузкой гыюкозой и бсз нее и после подкожных ияъекций $1 / 2 \mathrm{~cm}^{3}$ адреналина и небольших поз инсулина.

В 4 слугаях заболевания полжелудотной железы, явившегөся следствием 
болезии желчных путей, найдено было, что гликемия натопак ниже нормальной; гликемическая кривая после нагрузки глюкозой дает незначительное nовышение и досгигат затем цифр значительно меньших чем в норме. Гилогликемия у этих больных иногда сопровожлается характеріыми симттомами (профузиыс поты, дрожание, слабость, отрыжки и т. д).

При применсаии панкреалиеских ферментов в течение $3-4$ лней совершенно исчез.и объективые и субьектиные симпюоы гипериисулинизма.

Только в одном случас Гнлогикемиеское состояние наблюдалось и после лечения и было выявдено ннсупиновой пробой, которая, по мнению авторз, является самой чувсгвительной пробой.

Такие же иссиедовния были произзедены в 4 слугая гигеринсулинизма при дуоденальной язве и в 5 случяя после резекции желудка. У всех зтих больных бына найден ненормпльна резктия инсуяяного аппарата. В некоторых спучаях даже были обнаружены при дуоденальном зондировании расстройства внешней секреции поджетудониой железы.

Авгор отмеуяет значение повышенного тонуса вагуса для появления самопроизвольюй гипогтижемин, т. К. слуци язвы двенадц ітилерсгной кишки с резекпией желудка предсавляют явые влготонические симлтомы. С другой сго

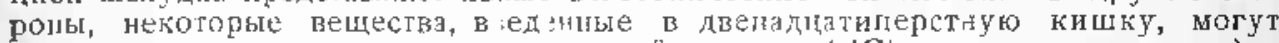
сгимуиюовть секрецию поделудоннй железы (НC), инкретин, секретин) и вызыв юг гиперинсулинемию.

Возможно, что воспилтельные изменения в жслудке, дуодепуме и желиых путях могут увелиивать секрепию вешеств, способных одиовременио вызыяать и увелимение кислотности и гиперинсулишемию.

A. Aуслендер.

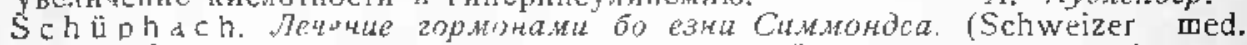
Woih, т. 66, № 50, 1937). Недостаточность передней доли гипофнза при богезни

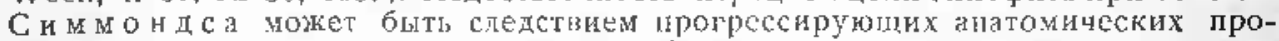
цессов, как зикачественая опухоль, лиро непрогрессирующих анатомических изменений, как атрофия, восплитеявые пролессы, трчвиа. Эго заболевание может иметь причиной и сифи.исии, наконец, оно может бй только функ-

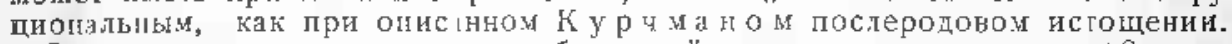

Одно из описаяых автором наблюдений относится к женпине, 8 лет, котор।я больна уже год. Б-ля весит 29 кг при росте $151 \mathrm{~cm}$ осповной обмен-40', кровлное давление $10 / 65$ и т. л., словом, - 1олинй симптомокомплекс болезни Сим нол са. Лечение препаратми переннй доли гипофиза (рraephyson), примснениое в течегие гола, дало резкое улучшеняе-вес б-ой повысклся до $44 \mathrm{kr}$, основной обмен-18'/я, появились отсутстзовавшие три уода менструации.

В лругом случэе, у 18-лстней девушк, примсление препрата передней доли пйофиза подкожно и пі ОS вместе с вытяжками овариальных и пцитовидной

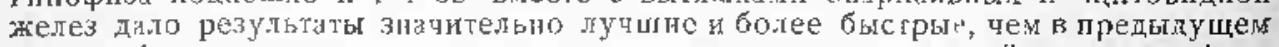
случас. Автор полагает, что ввиду пелостаточности шерелней доии гипофиза надиоченики и особенно щитовидая железа хишены сгимулирующело физиологитеского дейс:вия, поэтому следует в канесве вспомогательного средства прииенять горхоны надпочечника и овлри льные гормопы.

у одной б-ой 17 лет, весом в $29 \mathrm{kг,} \mathrm{при} \mathrm{росте} \mathrm{в} 155$ см, лсчелной описаппм способок, результаты были полүчены очень хоропие, несмотря на то, что после курсз течелия прошло нетоторое время до появелия первых симптомов улучшения, как если бы дейсгвие вы яжки щередпейдоти гипофиза нуждалось в некотором времени для окизіния втияння на коррелятивиые железы.

В некоторых спугая астении, в особениости при конститциональной астении, также следуё думать о прегипофизарной нсдостаточности Автор приводит тажже наблюдение, относяшееся к левущке 21 годэ, стридающей пристулами резкой слэбости, амепорреей, рлссройствми лицеварения, быстрым похудаяием, пони жением кровяного дівтения, у которой были подучены прекрасные резуліталы от лечения вытяжками передней доли гипофизя, в то время как никәкие цругие мегды лечения и укрепиягие средствл не приносили џикакой пользыт.

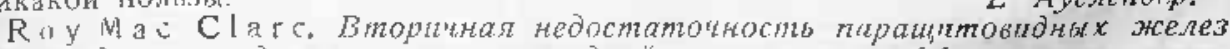

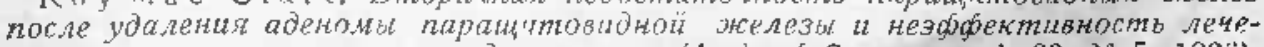

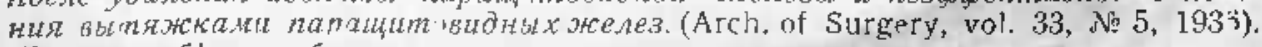
Женщине, 51 года, была произведена оперэция удаления прамиитовидын желез по поводу фобро-кистозного остента со сионтапыми переломами. Найдена опуголь паращиновидюой железы, примыкаюшая к нижиему полюсу правой 
доли щитовядной железы, вследствие чего была удалена вся правая доля. Слева был удален нижний полюс. После этого появилась тетания, которая вцачале купировалась кальцием, виостеролем, экстрактом парацитовидных желез; затем печение перестало давать эффект. Была сделана также попытка пересадки желез, но безрезультатно. Количество кальция в крови за 21. ме-

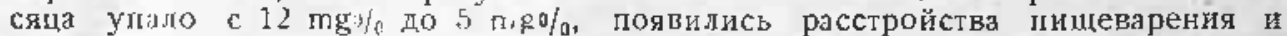
рвота, участияись судороги и все это привело болыную к смерти через 3 месяца после операции.

Автор приводит сборную статисгику паратиреоидэктомий, где ња 125 огераций, произведенных в аналогичных случаях, было 'l смертных исходов, 10 из которых были вызваны недостаточностью пар:щитовидных желез.

Отсюда явствст, что в этих слугаях имело место чрезмерное удаление нарацитовидных желез, и в настояпее время всемк признано, тто совершенно недопустимо удалять обе нижние парашитовидные железы, ибо могут быть случан, ге верхние парашитовидные жельзы отсутству кт.

Автор объясняет безусненность лсчения в описанном случае тсм, что вводимый витамил D из-за рвот не удерживался, а отсутствие витамина D в организме делило вытяжки пәращитовидных желез неэффективными. $E$. Aуслендер.

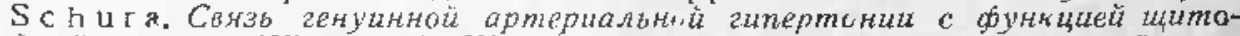
видноӥ железы (Wiener. klin. Wschr, № 14, 196). У больных генуиниой артериальной типертопией пасто наблюдаются длисельные тахикардиц. Это дало

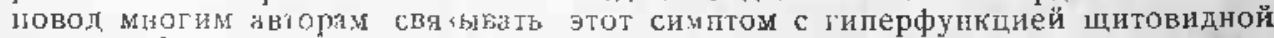
железы. Однако исстедования основного обмсиа, а тақже иечение иодом далеко не всегда подтверждают эту гилотезу. $\Lambda$ втор разбираст резличные возможности возникновения генуиной артериальной гипертонии, как при участии щитовидюй железы, так и без ее унсстя, возможности сдучйных совпадений типертония и гипертиреоидиза и т. д. В целом, однако, автор склоняется ж мысли о связи обонх состоннй. Он уқазнвнет, тто согласно Ба у э $\mathrm{p}$, повышение давлеиия в Sinus caroticus вызывает резкое повынение кровоснабжения щитовидиой железы и лалее ее гиперфугкцию. Автор считает мало вероятным, 'то гипертиреолдзм явтяется причиншым моментом возникновения генуинной артеризльной гипертонии, но он допускает, что оба симгтомокомплекса могут зависеть от одной общей причины, как папр, повышеиной функции базофилыных клеток гипофиза, при которэй повышается выделение тиреотропиого горяона.

Автор изыскнвает методы для доказательства связи генуинной артериальной гипертонии с гилертиреоидизмом, но так как исследования основного обмена и уровень иода крови не дали огределенных результатов, то он прибстает к следуюшему методу: $у$ больных генуинной артериальной гипертонией он лодситывыет колнчество эритроцитов с ви альной трлиуляцней, число которьх обычно повышсно при гилертиреоидизме и у люлей и животных, которым вводится гормон щитовидной железы. Количество таких әритроцитов по разным авторам равияется в среднем $8 \% 0_{0}$. Почти у всех исслсдованив типертоников это число оказалось гораздо выше. Цля того, чтобы еще подтвердить свои наблюдения, автор давал гипертоникам иод или дииодтирозин так же, как это делают при подготовке к операции при гипертиреоидизме. Тахикардия и другие симдтоиь ослабевали, и одновременно падало писло эритроцнтов с витальнй зернистостью. Тогда же, когда симптомы не ослабевали, яисло этих эризроцитов не изменялось. При прекращснии дачи дииодтирозина пулљс снова ухыцасл и количество витальио-зернистых эритроцитов повыналось.

Автор прнходит к твердоку убеждению, что в результате генуиниой артерилльной гиюертонии весьма часто, хотя и не всегда, поянляется гиперфункция щитовидной железы вследствие покышенного кровеснибжения этого оргына. Он подюркивет, что течение генуинной артериальной гипертонии тииодтирозином недопустим, так как при длительной даче благолринтый эффект переходит в токсический, как это приходится видеть при длительном лечении Гипертиреондизма иодон.

Ю. Канель.

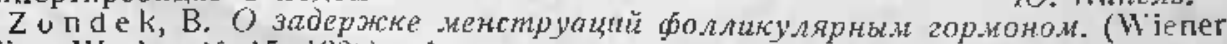
klin Wschr. № 15, 1934) Автор кратко изатает вопрос о роли различных факторов, вызывающих менструақию. Описывается ряд разнообразных теория, и в результате автор прихолит к выводу, что женструация-это комдлексиый rормоналыныи процесс. Механизм менструации зависит как от гонадотропного гормона передпей доли, так и от гормонов яичыика-фолликулина, лрогестина. 
Изыскивая методы летеняя женской стерильности, автор пытался бороться с гипоплизией матки впрысживаниями большихдоз фолликулига. Он, в среднем, вводил от 100 до 200 тысяч единид в течелие одлого менструального цикла. В резултате дейстинельно лолучалосы декоторое пабухание матки, но одноврәмено замечено, чго следуюцая менструация либо отодвигается, либо вовсе выпұдает. Часто такой же зффект получался и лри 70 тысянах единиц. Всего приводится 12 случаев; менсгруадии отодвигілись на 6-70дней Механизм этого процесса авгор объясняет тем, тғо фолликулярный гормон задерживает пременструаныую перестройку слизистой матки и этим тормозится образование же:того тела. Торможсние передается через голадотропиые гормоны передней поли гипофиз. [Товидимому, меняется взанмоогыошени: межуу проланом А н Б, так жак у женщин саменоррееі после введения фолликулнна увелиинается выдеасиие пролана А.

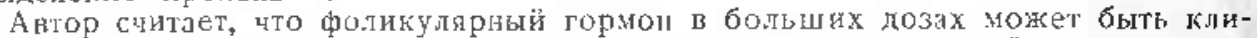
нически исподьзован как средство дыя вызывания искуссгвенной пменориен. 10. Канелb.

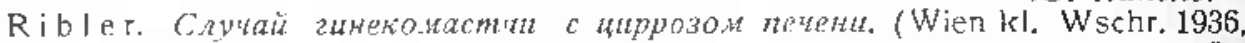
№ 35). Автор описывает сиучай тннекомастии в сиязи с пиррозом лсчени. On указызяет, что в литературе отмемело свыше 15 таких сиучаев. Патогенез конбнлаци эгих заболеваний автор объисняет следуюгия образом. Как известно, тирроз чрезвытайго насто связан с хроннческим алкоголизмом. С другон̆ стороны, ири циррозе неодноратно паблюдась дефективность яичек, которая отдасти зависнт от токсинов, встречнюцихся при циррозах нечени, огчасти жс от алжоголизм!. Возможио, что имеется сенейная конституциональная нелолнодениост ткан петени и яинк. У таких лия ғередко встречаюг гинекомастию. Росту грудной железы способствует женский половой гормон, залерживается же этот рост мужским горшоном. Гравда, тинекомастия зависит не исключительно от гормональых влияний, так как у кастратон далеко не всегда развиваются грудные железы. Но лри гинекоистии тасло наблодают неполноценность янчек, гилергызию коры надпочечника, а в рапем возрасте и тимуса. Прн цирроз:х печени может поврсжзиться копституионаньно сибая ткань яичек, и появнвшійея вследстие әтого педостаток мудскоуо полового гориона в некоторых случая может повести к разитию мужской грулной жслезы. В некоторых сяутаях гинекомастии монно полуиит удовлетворнтельный терац: втический әффект щри помощи нужского лолового гормона. Этот же мстод лечения следует нспытать прл гиперрофии женских грудых желез.

\section{в) Акуиерство и гинекология}

(O). Канель.

$\mathrm{Schultze-Rhonhof,F.} \mathrm{Jeqente} \mathrm{pruritus} \mathrm{vulvae.} \mathrm{(Zbl.} \mathrm{Gyn.} \mathrm{1937,} \mathrm{11,610-}$ 613). A. ла основанин собственых наблюдений рекомегіуст лля лечения эссенпиальіого pruritus valvac чистый пцелияый мед, обилыные смазывания которым дали оглнчне рсзультаты в ряде случаев этоло зчболевания. У одной подобной бопьой, через несколько дыей шосле примепеня меда совериенно исчезло мучительне чушсгво зуда; спусг некоторое времл поспедний появися слова, но в пезпачительной стелени и после нового смлзывания медом немехленно тропел; отсутстве редидива в тепение нескольких месятев Механизи

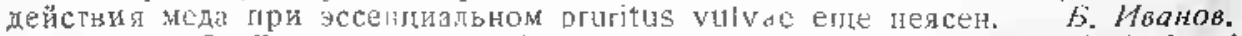

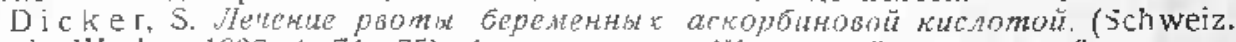
med. Wsthr. 1937, 4, 74-75). А. примсни в Кеневской акушерской клинике

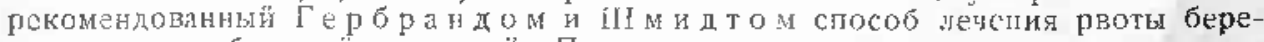
манных аскорбиновой кислотой. При этом оказалось, что уже после лервых

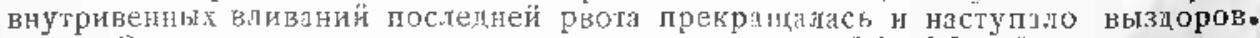
ление. В тяжелых случая сжедненно вводинось по $0,1-0,2$ с. дось от 10 до 5 внивлний.

b. Иоанов.

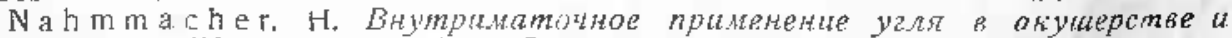
2инекологши. (Mtschr. Geburtsh u. Gyп. 1937, 104,5-6, 353-254). На основании свонх многолетин наблютелий а. рекомендует внугриматолне применепие угля в случая безлихорадочных и лихорадочны эбортов, общей септической инфекцин, пуэрперального эндометрита, кесарского сетения послс разрыва плод-

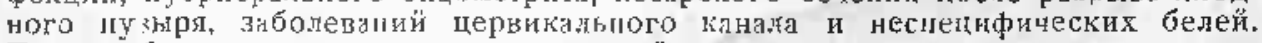
Посте обнажения зеркалом влагалицной части, захватывания пулевыми пиицами передней губ́ы матотного зсва и протирания канала шейки, дерез него 
возможно вяше R полость матки вводится угольный карандаш; в канал шейки во избежание преждевременного выделения частиц угля вводится на 2-3 даса марлевая турунда. IIо нилюдениям а. применение угля дает одень хорошие результаты в смыс Іе быстроты действия и улучшения местных явлений и обцего состояния; при этом отнюдь не исклюдается и общее лечение септического процесса. Никакого вредного влияния угля на ткани а. не отмечает. Благоприятное действие угля обусловливается его въсокой адсорбирующей способностью, вызывтющей высушивание поверхностыых тканей, создающее неблагогритную срелу для бактерий, а также обезврежив ющим действием угля в отношении токсинов бактерий с затруднением всасывания секрета лохий в ток крови и лимфи.

Ph ilip p. K клинике эндометриозов. (Zы. Gyn. 1977, 1, 2-3). А. указывает, что мпогие случан зндометриоза яи ников и брюшной полости возникают ретроградыым путем. При налични у больных резко выраженной дисменорреи и болей, усиливающихся при менструация, следует при дифференлиальном диагнозе подумать об эндометриозе. Эго особенно относится к тем слупаям, где раньце подобных явлений не наблдалось и они появились только в пожилом возрасте. В отношении лечения у молодых женщин а. рекоменд vет для сохранения способнос'и к занатию пронзводить операцию; в пожилом возрасте показаяа кастрпдия. Консервативная операция по поводу эидометриоза яиниижов не всегда приводит к бесплодию; после облучения яичника рентгеновскими луг̆ми эєдометриоидия ткан опухоли теряет способность отвегать на гормональное раздракенис.

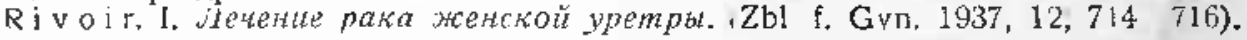
Рак жеңского моцеиспускателього канала встречается сравнительно редко и всегда посіє 4 -летнего возрлста. Летение дает тем лугшие результаты, чем раныше посавлен диягиоз; в запушенных случаях с метастазами в паховых железах прогноз леблагоприятный. Нанлучиим способом является комо̄инированн:я лучистая терапия, состоящая в об уучении опухсли радием, а областных лимфатических желсз-рен геновскиии лучани. Способ, согласно наблюдениям а., дает хор ии ие длителығые результаты и не вызывает, в противоположносьь оперативцону лечению, никаких функциональных рассгройсьв со стороны мочеиспускательноло канала.

Б. Иванов.

Molling E. Быолсия при заболеваниях грудных желез у женцин ( runs Beitr. 1937, 165, 2, $192-207$ ). Биопсия является ценным вспомогательным средством дыя дијназа заболеваний грудных желез, особенно зппкачесгвенного харлктера. У па зания многих хирургов на возможность поста нее бурного роста онудоли, огвергатся пзтолого-анатомами на основании биологических данных и результатов экслеримснтального изучения опухолей. А. суитает, что присущие биолсии оплености могут бын значительно уменьшены правильной установкой показаий и тпательным производством ее. Он шриводиг детали техннки биопсии и указывтет, что пос елняя требует клинической оз̆сановки и хорошего досгупа $k$ соответствующей пбласги груднй же цезы с иссечением достаточного количества ткани ее в нлдлежащем месте. Наиболее подходяџим для этой цели явтяется дугообр нзный рззрез по нижнему краю грудной железы по Га р д е г сй еру с откидываниек ее кверху. С целью обезболивапия следует лрименять внутривсныңй наркоз; исссчен ле лучше всего лроизводи әь әлектрическим ножом Бсли, в результате гиссо огичес ого исследования, окажется, уто заболсвание носит здокачствснный характер. Показана немедленная радикальн я операция, являющэяся вщесте с тсм и единственным мегодом, предотзращаюция опзелост бурного роста опухоли после биогсии. Б. Нванов.

W i em cr. Ieqente macmama inunch mad. Wschr. 1937, 4, 132-133). G целью профилактики мастига a. рекомендует лечи ь трсцины на сосках: пос е прсдзарилельного смазывания их $10 \%$ раствором новокаила и прижигания $0^{\circ} \%$ ра:'твором ияиса иаладывается стерильная повязка с индиффереитной мазью. Для пיддержания секреции мотока 3 раза в день пронзноди ся отсасыванис его. Спустя 3 дня процесс большей тастьо настолько утихзет, что ребенка можно сно а прикладывать к груди. При воспалслии показапо пемедленное рентген-облудение $\left(10^{\circ} / 0\right.$ HED при FH-расстоянии в 35 см и 0,5 мм мелиом фильтре). Облучения прои водятся в теqенне 3 дней Если, несмотря на это, все же остается инфиньтрат, ироводится дальнсйшее лечение ламлой Sollux. При гнойном млстите абсцесс доласн быть вскрыт, но только при наличии ясно выраженной флюктуации; при этом дсстаточно небольшого отвер- 
стия при помоши термокаутера: наложение контрапертуры а. считает излишним. Юолоств абелссса промывается раствором риваноля. В дальнейшем производится отсасывание по Би ру, безболсзненно олорожняющее абслесс. Б Нванов.

$\mathrm{R}$ ax as. Hеsponozuческие расстройсnва nри беременности. (Philippine Is]ands Med. Ass J. V. 16 IX 1936). Авторы взяли под свое наблюдение 78 беременных женшин. Они отметили гипогликемию, соедиленуу ю с неврологическими расстройствзми, у 58 из ғих. Симптомы сводились к парэстезии, сидорогам, мышечным подергивания, местным отекам, стеснению в груди, боли в спине; ломкости нолей, кариесу зубов, истолению волос и мышетной слабости. Авторы полаглют, что прежле всего происходнт нарушение кілыциево-фосфорного равновесия, вследс вие чего первные расстройст иа могул начаться еше до выявления гилогликемии. ІІричнной служит иибо недостаточный подвоз жальция или D-внтанин, пибо недостаточность прратиреоидных желез. При бсрибери каз у беремениых так $n$ н неберененных женщин снижелия кальция не происходит. Это важно длg дифферелйильного дизгыоза. Алалогитые невроцогическе симтомы проявляются при беремениости у жениин, стралающих туберкулезом и сердечной нсдостаточностью При проведении кальдиевой тсрапии у беременшых необходима больпля осторожность. Несоответствующее надобиости введение пальция может сделать роды более тяжелыми, вероятно, изза иреждевременного окостенегия черепл плода, ұто принодит к пеобходимости кесарева сечения.

В. Цембская.

\section{2) Эnидемиология}

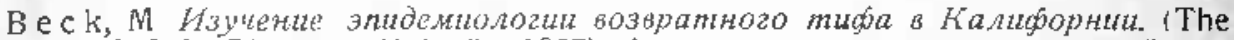
journ. of lnf. Diseases, Vol. 6(1, 1937). Автор установил, что возвратный тиф әндемичен в Калифорнии. В теленис 1921-1935 ю. было зарегистрировино 10 случаев в 9 очагах, рпсположелных в горах на высоте б0, футов. Было выделено 13 штаммов спирохет морфологически близих рекуррентых сиирохетам полевых грызунов. Инкубационный лсриод у мышсй, зараженпых этими спирохегам, достигал 114 дней. Спирохеты, выделениые от человека и грызунов, оказались резистентными қ замораживзнию, сохранялись в сгустках крови и в тканях и астанались неловрежденныии в тсцегие 95 дней в дефибринированной крови барана Автору удалось полуцитг иммүные сыворотки, вводя морским свинкам слирохсты, вықеленные от белок. Зацитное действие этих сывороток выявлялось кик против гонологиныл, так и против гетерологичных штамиов спирохет грызунов, а в одном случас такая антисыворотка оказала зашитное дейслвие и при заражении спирохетами, выделспными от человека.

На основании әтих даныых автор приходит к заключению, что штаммы слирохет грызунов н человека идентичны морфологичекки, а жабораторные животпые в равиой стспени восприимпнвы к пим. Автор лолагает, что сгирохеты грызунов могут непосредслвенно передаваться qслопеку,

I7. $P$.

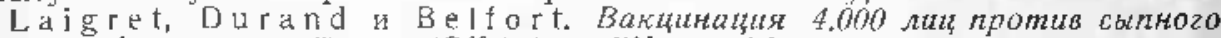

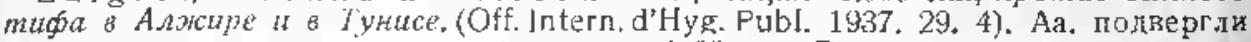
вакцинации против сыпного тифа сеыше 400 лиц. Вакцина ғатовнлась из крысиного штамма сыпюотифозного нируса, полученного от $\mathrm{F}$. C п а р p о у. Вакцину готовили по мәтолу, описанному Николлем. Сперва вирус высушивали, а затем обволакивали его яичным желтком и оливконым маспом. Вакцинировали двукратно, с промежутком в $20-30$ дней, притем для первой инъекции брали мозг зараженной морской свинки, а для второй-зараженной крысы. Отметается жезнатительное число реакций у привитых. Заболеваемость сыпным тифом среди привитых была залительно нияс, чем в контрольой группе. $I I K$.

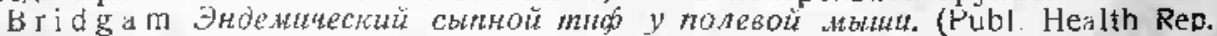
1937. 52. 21. 679). Einе в 1934 г. было устанолено, ито в птате Алабама имеется эндемическй сыпной тиф. Однако до сих пор резервуаров вируса найти не удавајось.

В настоящее время этот пробел уже восполнен, так как удалосъ обнаружитъ вирус эндемического сынного тифа в млзгу старой полевой мыши iPeromyseus polinnotus). При заражении морских свинок этот вирус давал повышение температуры на 6-е сутки и тиличный скротальный феномен. Олы: сравнительного изучення данного иируса с имевшимся у а. лабораторным шгаммо эндемического (крысиного) сыпнотифозного вируса показали их полную идентичность, 
G reen, C. Серологичские типь гежолитицеских стрептококков во время. эпидемии скарлатины. (J. of Нyg. 1037. 37. 2). А. производил типирование шттммов гемолитического стрептококка, выделенных им из зева скарлатинозных больных. Всего был изучел таким образом 1581 штамм. Титирование производилось по схеме Грифиц а, лричем тилировать удллось большую часть обследованиых культур (1488). Были обнаружены виды всех Іати типов Грифиц а. Исследование показало, что в предэпидемическом џерноде ча ще других выделялся тип $V$. Впоспедствии стал чаще выделяться тип іl. Те больные, которые сохранили стрелтококка ко времени выгиски из больницы, очычно имели тот же самый тип стрептококка, что и при поступлении.

A l b ison, V. D. и R rown, W. A. Реинфекция как прииина осложнении и рецицивов в скарлатинозных больнищах. (J. of Hvg. 1937. 37. 2). Гемолитические стрсптококки, выделяемые из зева скарлатинозных больных, относятся к различным типам str. pyogrnes. Во время пребывания в больниде больные заражаются от соседей стрептококками других серологическид типов, отличными от тех, которье имелись у них при поступлении. Тптательое исследонание показало, что из 47 болызых в общия палатах ?3 (т. е. 70,20\%) подвергіись реинфекции. Из этих 33 человек 18 дали осложнения. Все же больные, которыс были помсщены в изоляторы, или же находились в палатах, где у всех больных. имелся один и тот же серологический тип стрептококка, до самото колда пребывания в больнице не дали осложнений. Так называемые поздние осложнения при скарлатине развиваются больщей частью на третьей льеделе от натала заболевания, т. е. когда первичнос заболевание уже проходит. В 10 слугаях аа. даблюдали типичные клинические рецидивы скарлатины во всех этих слуџаях вторичное заболевание совлало с реннфекцией болыных новым сєрологическим типом стрептококка.

А. а. считают целесообразным помещать скарлатинозных больных в изоляторы. В тех случаях, когда зто технически не выполино, желательно соединять выесте бољьных, имеющих стрептококка одного и того же серопогического типа. $C$.

Watson, R. Bспьика сқарлатинь и тонзиллита в Донкастере молочного лроисхожденгя. (Br. Med. J. 19.77, стр. 1189). В г. Донкастерс (Англия) встыднула эпндемия скарлатйы, которая продолжалась с 9/XII по 20/XII 1936 г. Всего заболело 135 человек. Полробнос эпидемнологичскос обстедонание установило, что на молочной ферме имелся доильщик, который целую неделю болел аңгинй; у этого доилыиика ребенок болел отитом, ирицем из гноя (а также из отделяемого зева нескольких больных) были выделены штаммы

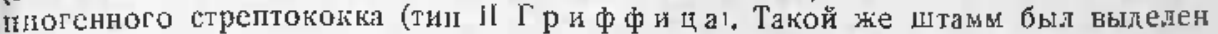
из молока от коровы, страдавшей поражениек сосков. Молоко с ээой фермы полуцали 380 сещсйств (1343 пеловека); заболело типипой скарлттиой 1 ц человек $\left(10^{\circ} \%\right)$, ангиной без сыпи $229\left(17^{0} / 0\right)$.

I ка сразу прекратилась.

H. $K$.

Kudo, Uragushi, Matsuda, Hashimoto. Ceponozaчeckoe pozautue supyca sнцеgjastuma 1935 2. Tокио и вupyca Cak-Лyu. (J. Immunol. 1937. 32. 2. $129-37)$. В качестве материала для вакцинации кроликов аа. пользовались 10\% эмульсией мозга зараженной мыми. Эмульсию цегтрифугировалй в теqение получаса при 50.0 оборотов и верхним слоем пользовались как антигеном. В работу пускали только таких кроликов, сыворотки которых до ва́кцинации не содержали алтител $\mathrm{k}$ вирусам ялонского и американского эндефалита. Инъекции производились слерва под кожу, а затем внутрибрюшинно с промежутком в + дня. Ни местнон, ни обией реакции у вакцинированных животных нс замечалось. Опыты по изучению пейтрализующих свойств в сыворотках вакцинированых кроликов дали следующие результаты. Сыворотки иротив япоњского вируса нейтралнзовали не только гомологичный вирус, по-частично-и гетерологичный. Наоборот, сыворотки кроликов, вакцинированых американским вирусом, пейтрализовали только гомологичныї вирус. Эти оцыты подтверждакт ирежіие сообщения относительго того, что вирусы ялонского и американского энцефалитов родственны, но не идентичиы.

H. $K$.

Rjokich i l n a a. O способе заражения при эпидемичском энцефалите. (La Presse Mid. 1937. 21. 386-87). В настоящее время различиые аа. поддерживают 2 гипотезы о способах заражения при эпидемическом энцефалите: 1) церез. носовые пути и 2) нерез укусы комаров. 
ІІервая гипотеза базируется па пличии типичных измешений в мозгу при экслериментальном заражении терез лос, а также на факте присутствия вируса н фильтрате лосовой слизи больных. При зарлжении животных через нос вирус сперва размножается в bulbus offactorius, а затем в мозгу. Переносить эти даниые на целовека пока еще рано.

Гилотеза о роли комаров в распространенин энцсфалита была впервые вы. сказана в 19 З г. М и т а у у о й̈; впоследствин ее поддернивал ряд аа. (натало эпидемн через недеми поспе г ивления комаров). В экспсрименте успех был лостигнут, когда комаров (culex trit tetiorhyn hus) заставляли сперва кусай больных пюдей, а затем чере 1 -4 пенен-мышей. Р 2 опытах из 7 удалось таким образом обларужить вирус, однако, лишь после нескольких пассажей.

Болсе удачтыс результаты удалось полудить, растмрая зараненных комаров и вводя эмульсию в иозу иышам. Лучшие результаты опят получались после घассирования. Такии образом песомненно, что комары являюгся резервуаром вируса, 10 детльне их роль пока не изуцсна. Важіо, цто иненсивиость эпидемин пе стоит в связи с количествон комаров.

II. $K$.

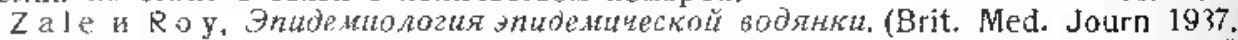
1110). Аа. нзучли в Ипдии заболевание. полугившее пазвние эпидемической волянк. Опо было опислно в провиниия. Ннбюдались случаи, кончавшиеся леталью. Было отмечено поятление этого заболевания среди пиц, питавшихся

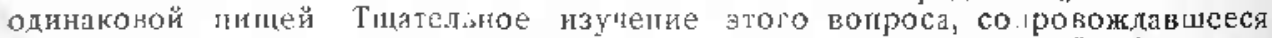
безулрсчно посгавенныни опытами ия пюдях, показало с полюй уо́едительностьи, тто все явления, развиващиеся при так назывиемой эпидемической воднкке, зависят от лриема в пищу горчичног масла, содержащего вредно действуюшее начало.

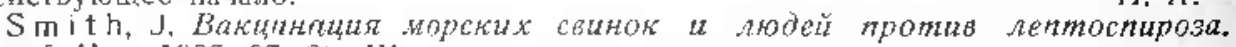
(J. of Hvg. 1937. 37. 21. Животных иммуцизнровли живыми авирулентными нли убитыми нирулентыни куштурами sn. i:terogenes. Людей (дети в возрасте от 8 ло 14 лет) мимунизиовали только убитыми культурами. Культизирование лроизводилось на среде ваниеи, тибо добанлением разлнтых химических вещестз. Выработка иммунитета определялась наличием антител, а у животых также заражснисм вирулентной куньурой Sf. icterngenes. Выяснилось, ато морские свинки вырабатывали очень хорошнй иммунтет, причем иакциация гомологичным штамом

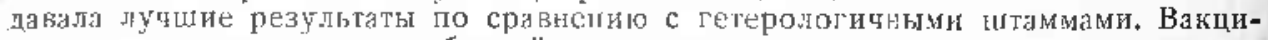
пация сопронождалась веработкой спирохеголизинов, причем а, установиј, что лри тите $1 / 6$ уже имести досгаточ.л превенивных антител. У детей титр спирохетолизинв был ниже, и а. поитаст, цто в чсловсческой практике следует юобще ґолзоваться большими дозами вакцины (в пастоящем исследовании а. вводил 1,0 и 2,0 с недельным промежугком).

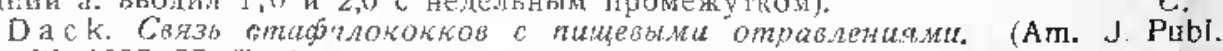
Health 1937. 27. 5). А. излагает литературные данные, касиющиеся роли стафилококков в пишевых отразления. Fуо собостеныле олыты сволились, главным образом, к изучению токсинов выделеныых им культур. В то время как мнотими аа. подтертивнтся знадение пишевого пролукта кан питательной среды,

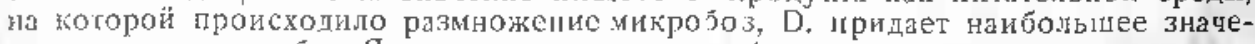
1ие симому микробу. Ядовитое вещестзо стафилококкон, вызынающее отравтение, гредсталяет собой не экзотоксин, но жокет быть скорее отнесено к эндотовсннам, Отличалса зитительой резистентносыю к действию нысокой и низкой температуры, имеющей большое значение в пагогелезе этих иятоксикаций.

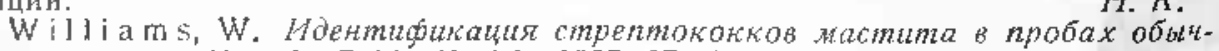
ного полока. (Am. J. Publ, Health 1937. 27. 5). А. yдалось показать, что при маститах у коров нз их молока даше всего удается выдепять культуры str. agalactiae. Maстит представляст собой довольно распространеное заболевание среди қоров, и кушьтры стрептокоқков чъсто упается выделить при таких форыах 3 болевания, жоторые клинически ничем себя пе проявляют А. обследювал 630 проб обычного продндного молока и в 441 сл. выделил культуры стрептококков, из которых свыше $50 \%$ составлял str. agal ctiae. А. подробно описыв ет биологические свойства стрецтококка әтого вида. Интересюо, что наибольисе количество культур Str. agaldctiae дают те пробы молока, которыс содержат много гнойыых клеток. Дия выделения культур а. рекомендует сперва ставить молоко в термостат, а затем делать посев на агар с кровью. $H . K$. 


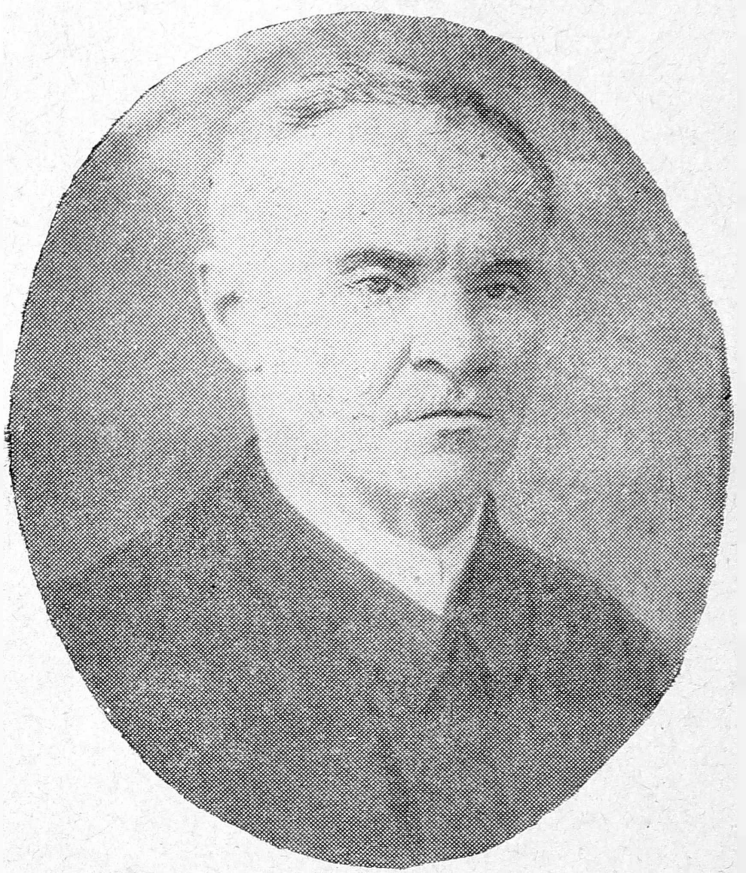

\section{Профнсоор владимир Нккслаевич Воробьев.}

25 октября 1937 г. трагически скончался грофсссор Краснодарского мединститута Владимир Николаевич Воробцев. Владимир Николаевич родился в 1 \$1 г. в г. Мосальске, Калужской губ. Среднее обрззование закончил в Гармской гимназии в 190 г и высшее в Казанском университсте, на медицинском фикультете, в 1907 году. В 1908 году был зачислен на должность штатного ординатора детской клиники Казанского гос. университета, находившейся в завед. ироф. Меньшикова, здесє затем он прошел стаж ассистента клиники. С 1914 ло 1918 эод был мобицизован на военную службу и зачислен старшим врачом дружины. Весной 1918 г, Іосле дсмобйлизации, возвратияся к весту службы в Кажань, где в течение 1918 -2н гг. читал обязательные курсы и вел практинские занятия со студентами 3,4 и 5 курсов. В 1920 г. был избран медицински факультетом па должность секретаря. В 1922 г. Занимал должнось секретаря обществз врачей при Казанском университете, с 1926 г. по 192 г. состояд в должиости заместителя декана факультета. В 1927 году представил н факультет для оценкі свою работу на тему ..Наблюления над атимарован ными животными“; эта работа постиновлением факультета признана работой 
Высокой паучной књалификацин. В 1929 году п1о конкурсу избрал па кафедру детских бо:езией Кубнкско мединститута. Он состоял членом правления Всесоюзного обцества детских врачей.

Профессор В. Н. В оробь $ө$ в являлся пелиатром с большим клиническим олытом и прекраспой научнй подготовкой, Бго днссертация "Наблюдения нал атимироваными животными" представляет больцой экспериментальный труд, проделанный над крупными животными (поросятамн), выращиваемыми после экстирпаци gl. thymus ғ течение длительных сроков, является трудом высокой ценности. Рлд работ В. Н. Вороб ве ва, законченых им в Казани, касался патологии эाдокрннной системы. Таковы рабогы: "Сиучай врождениой сенейной миксэдемы“ и "Опыт пересадки цитовидиой жслезы "К клинике Dystrophia adiposomgenitalis". Придавая болшшое आ1аниие роли конституции в вогросе питания детей грудного возрасти, он касался этого в одной из сlлокх работ в Каз. мел. жура в 1928 г. Интереслыми его работами являютея

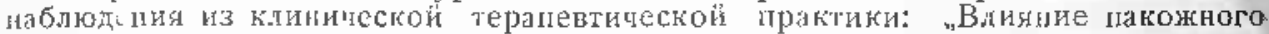
лрименения старото туберкулина с терапевтической цслью на больных туберку.яезом ${ }^{a}$ и „lеление коклюша впрыскиваниями серного эфира“"

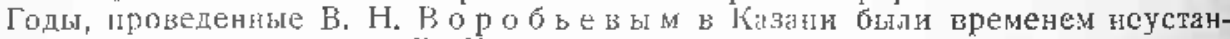
иого плодотворного труда. В Казин он пользовался уважением как со стороны членов факуыьтета, так іл среди учащенся нолодсжи, кат выдаюшийся лреполаватель. Большой полулярностью и любовью оп пользовался и среди населеияя, обрапаниегося к нему за врачео̆ным советом.

Заняв кафедру в Краснодаре, проф. В ороб в е в гивное впималие посвяшает оздоровителы мым мероприятия для детского возраста. Забота Советской власти о детих поспужила базой, па основе которой и героходит вся рябо.а покойного в Красподаре. Показателем этого являются работы: „К послановке оздоровительных жеропритий в детких лечебных учрсжленгях", грофилактики детского возраста“, „Іробиема постановки оздоровитстьной помопи детям на курорте Анапа“ и другие работы.

Проф. В. Н. Воробь в был врачом-общественикком. Будучи члеиом горсовета в Красподаре и работая легом на курорте Алала, он не мало положил забот о эучшей организиии лечебной ломощи детям местного края и курорта

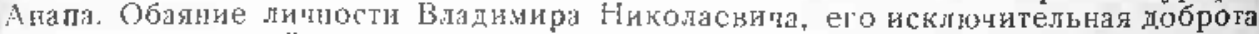
н скромность, крайняя дслнкатность и чуткость ко всем обрлшавшимся к иему, юлубокий опыт и знания прнвлекали к нему громадное число нуждавшихся в его совете. Он не унел и не мог нитому отқазывать в помощи. Все, знавше его, на допгие тоды сохранят о нем светлую память.

Iроф. B. Меявииков.

\section{Хроника.}

10 ) В результате закона от 27/Vi 1936 г. рост рождаемости в нашей стране особенно резко увеличилс. Наприср, в иоске за 5 месяпев 196 г. (с 1/l го $1 / \mathrm{VI}$ ) родилось 30.170 детей, за то жс время 193 г. родилось 56.398 , т. е.

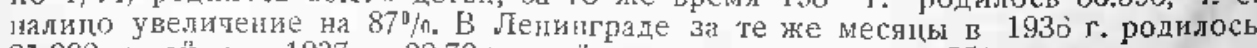
21.980 детей, в в 1937 г. 39.79 ! детей, т. е. увелименне на 5.5! \%.

В Азово-Черноморском крае: за 1-й квартал 1936 г. ролилось 47.4 0 детсй, за I квартал 1937 г. 6.800 детей, т. е. рост на -6\%; В Марийской АССР за 1-ї квартал 1936 г. родилось 5.436, за 1. й кв ртал 1937 г,-8.07\%, т. с. увелиление на $48,5 \%$. АССР пемцев Поволжья за соответственыне месяцы дает $5.41 \mathrm{l}$ и 8.333, т. с, отять-такн увеличение на 53,1\% и т. д. Одновременно с увелиयениеи рожпамости ндет резкое слиженте абортов. За 5 месяіев аборты снизились на $901 / \mathrm{c}$.

1(18) ГІаление рождаемости в большей части калиталистических страп Европы продолжалось в 1 \36 г. и в тервой ноловине 1937 года. Во Франции родилось в 1936 г. 11) $1(1500$ детей меньше, чем в 1935; за ұервую лоловину $19<7$ г. умсньшенис рождений по сравнению с $1936 \mathrm{r}$. уже ранғо 90\%. В Чехословакии число рокдегий в 19 иг. на 3600 (-2,30) мсльше, чем в 1935, а за первое полугодис 1937 г. на 1500 меньше, чем за тот же период 1936 г. В Венгрии

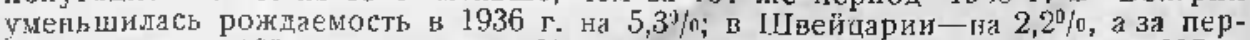
вую половину $193 /$ г, -почти на 6/6. В Австрин за первую головниу 1937 \%。 
рождаемость была на 3\%о меньше, чем за 1936 г. По сравнению с 1933 годом рождаемость в Венгрин, Фрағции, Бельгии, Чехословакии, Болгарии и Австрии снизилась в $193 \%$ г. на $7-8 \%$.

109). Удаление обширного упастқа мозговой коры было произведено недавно в США без какихлибо тяжелых последствий. У больного, страдавшего постеэенно учащяющимися приладками эпилепсии после леренесенн й в детстве травмы, была иссечена кора левого полушария, начиная от места соединсыия Роландовой и Сильвиевой борозды до Gvrus supramsrginalis и от нижней те. менной до второй висопюй извилины $(6,25 \times 3,8$ см), то есть центры речи Брока и Вернике. Между тем, несмотря на то, что сам больной и все члены его семьи были правшами, не постедовало никакого расстройства реди. В по. следовавших за сообшением об этом случае прения видные американские хирурги высказывили предлоложения об индивидуалџюых вариантах центров локализацик и о возможной эедооценке знахения правого полупария.

110) Нахождение элементарных тслец в ткани злокатественного новообразования, как в первичной олухоли, так й в метастазах, удыется при окраске тонких мазков из выступаюшей па поверхности разреза серозной жидкости по способу Пашепа или пользуясь новейшими методиками. Положительный результат был получен как при раковых и саркоматозных опудолях человека и животных, так и при эрлиховском мынином раке, куриной саркоме Роуса, крысиной саркоме Иенсена и кроличьей эпителиоме Броуп-Пирса, а также в культурах раковой ткани.

Если љанные этого предварительного сообщения получат полтвержделие, то зиачение сго, как теоретиеское, так и практическое, будет огромио.

111) Наличие связи между пиоррей и присутствием витамина $\mathrm{C}$ в организс установлено в Гарвардской зубоврнцебной школе путсм олытов на 弦ивотных и эаблюдений на больных. Огсугствие или недостаток этого витамина в организмс благолрияссгвует развитию чиоррси; ввсдение аскорбиновой кислоть мли продуктов, содеразаи мпого вигамина С, ослабляет этот процесс. Терапевтическая доза-около $150-200$ мг в деніь.

112) Изучениси канцерогенных свойств табака уже несколько лет занимастся известный аргентинский онколог Роффо (старшия). Известна относительная қастота рака на протяжении пымового хода ${ }^{4}$ у куриыншиков. Роффо приводит данные, имеюцие почти пқенность эксперииеитальных: на 5000 женщин, страдэющих раком, локализлция опухоли па протлжении „дымового хода “ была обнаружена у 42 ; все они много курили Канцрогенное действие принадлежит не пикотишу, а продуктам сгорания табака. Ошыты ша кроликах показали, цто наибольшей активностью обладаег продукт перегонки табака при $350^{\circ}$; химическое исследование этого шродукта показлло, что он содсржит большое қоличество конденсированных бензеновых ядер и гидрокарбоновых сосдинсний ароматического ряда (фанатрен, атрах н, бензпирен. дибеизаитрацен и тр.).

113) Театральные пьссы санитарно-просвстительного содержания псрсдағтся в CIILA по радио. Так, напр., в августе с. г. лерсдавалась пьеса, в которой женџина ринит палец, ухаживая за птицей и относится к этому пренебрежительно. Ярко обрисована оласность заражения колотых ран столбияком; большая роль в нљесе отведена энергичном сельскому врачу. Мораль пьесы излагается в конце, в краткой общелоступцой лекция, заниматей 4 минуты. Пьесы залписаны также на грамофопные пластинки, которье продаются по себестоимости всем орғанизация, ведущим санитрно-просветительую работу.

114) Оскорбитсльное проявление расовой нетерпимости содержится в сообцении правительства Индии о рсорганизации медицинской помощи в Индии от 25/11l 1937 г.: согласпо этому сообшенй, йдусы не имеют права зэнимать место обисств, врача в некоторых местностях, так как британские офидеры должны иметь для себя врачсй-апгкини.

I15) В Торонто (Канада) в настоящее время зарегистрировано свыше 275 случаев детского паратцча, с июня было 29 смертей. Во всей провиғций пасиитыватся 727 больиых.

1.6) Санитарное состояние Кореи продолжает находиться на весъма лизком уровне. Заболеваемость чрезвыпайно высокая. Смертиость среди детей моложе 10 лет доходит до $42,2^{3}$ н для мальчиков и $: 6,8^{0}$ / д для дсвочек. Борьба с летской смертиостьто находится в зачаточном сосгоянии, а в некоторых отношсниях цро нес нельзя сказать даже и этого. Тогда как нассление Кореи уже по переписи 1930 г. достигало 21 миллиона с ллотностью в 95 на квадратный киломстр, во 
рсей стране имеется всего 4 постоянно функционирующих яслей, обслуживающих 219 детей; лишь на время уборкн хлеба открывантся добаводные ясли. и тогді чиспо нх доходит до 960. Количество домов для сирот тоже ничтожно; они содержатся главны образом на часлные средства и вмеща от около Зе00 детей. В стране нмссгсп около 120(0) больных проказой, из которых под наблюдением врачей находится пе болес половины; срганизованный в $1935 \mathrm{it}^{\circ}$.

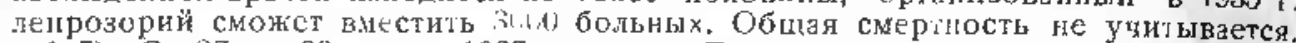

117) С 27 по 30 июня 1037 гола в Парижс проведен Международны Эидокринологический Конгресс, посвяценный как обшим вопросам эндокринологии, так и отдельым эндокринным железам.

Виднейлне эндокрипологи всех с ран дали доклады по вопросам биохимии, фармккодинамики, корреляцнн, клицики и тералии желез с впутренней секрециен̆.

C докладими выступали Roussy, Pende, Leriche, Maranon, Carrel, Houssay, Vincent, Sergent. Loeper, Purtier, Harvier, Fiessinger, Smith, Claude et Gougerot и др.

По предложению президиума Международного Конгресса проф. Д. М. Российским (Москва) были сделаны доклады ға тсмы:

1) Влияиие эидокұинных желез па секреторную и моторную функцию жепудка"

2) (Совместно с лроф. Г. П. Сахаровым) "Применение палкреотоксина при терапии сахарного диабета"; лослсдний докдап содержал изложение экспериментальн-кынииеских наблюленй, проводяшихся докладчиками пад ноњым жетодом летения сахарного диабста спєцияльным цитоноксином, нолученным пугем нммунизации животных поджелудочной желсзой человека.

118) На сессии Гэгиенической комиссии Лиги Наций, сослоявшейся недазо под председательством โаризо (Франаия), обсуждалась программа работ на ближайшие 3 тода; в ословном будут продолжены те работы, которые Комиссия пронодит в настоящее время. Энюдемиологичское бюро гигиенической комиссин вктючает Востогие бюро в Силг. пуре, которое собирает сведсния из восточных гортов, и Женевское бюро, огубликивывающсе данине об инфекциониғх болезнях, рождаемости и снертности из всех стран, где недется подобного рода статистика. Спсциальнй техницский комитет пересматриваст

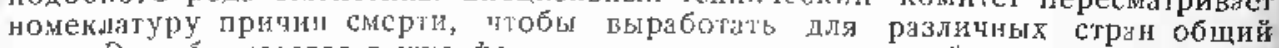
язык. Разрабатывается также форма представления сведений о насслении в отношении сго "витальности“ (рождасмости и прироста паселения) и состояния сто здоровья-заболевасмости, смертиоти и расиространени физитскки и лсихических дефектов, с учетом геогдафических, социлыных и экономиуеских услови и санитрио-гитиениеских меропрнятй. В рнде страп регистрирустся также матернал относиелын заболскаемос и и смертности родильинц с целью изучения причин этих явлений и оценки деятельности учреждений охраны материзства.

Малярийная комиссия подготовляет 1за 1930 год конференцию по вопросу o хинине и родственных препдратах и синдетических антимаярийных средствах. Имеетя также щредложение, т обы Лига органиова съезды предст.витеией различных органйций, занинающися изученисм проказы и разработкой про. тиволешрозных меропрнятий для обсуждения отделиных особо важеых вопроcon, на которые в б.лижаншсе врекя будет обралцено особое вниматие.

По иницитиве США Гигиеннтеская комиссия совместно с Междунар родивы 6 юро общественной гигиешы займеся изучением нового фонатренового производного морфия-дезоморфина, которое, повидимому, обиадает резко тожсическим действием и свойстном вызыватк приешкане В сферу деятельности комнссин входит также изучение различах мероприятий по борьбе с наркоманиямн.

119) В Iтрине со 2 по 6 июня с. г. под назвнием „Первые между-

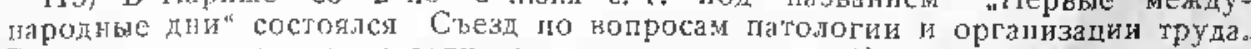
В порядкс дпя сьљ за стоялн следукщие вогросы: 1) преходавание гигиепы труда; 2) патолотия труда; 3) профилактика и лечешие; 1) законодательство. Наиболшшее число докладов ссвыше 20 было по 2-й теме, в том числе о хролическом отравлении окисью углерода, о скрытом бензолизме, а тетраэтиловом сянице, о свинцовых гпцуурях, о силнкозе, о труде беременных, о тробтеме аллерги, профессиональых дерматозах и пр. По з-й теме ряд локладов был посвящен оргащизаии 7 равматологичсской помощи, защите от действия 
лучей, вопросам психофизиология на траиспорте, охране чистоты воздуха и пр. По 4-й теме после докғада представителя Международного бюро труда Кародги о мировом законодательстве о профболсзнах, доктадчики от различных страғ (Франция, Италия, Германия, Бельгия и др.) п знакомили участников съезда со своия национальным законодательством о профболезнях.

120) Нобелевская премия по физиологии и медицине за 1937 г. присуждена стокюльмской высыей медицинской школой ютк называемым „Каролинския институтом") венгерскому профессору Альфреду Сцент-Гиорги за открытие биологических процессов окисления, протекающих под влиянием витамина, и за исследования по катализу фумаровой кислоты.

121) Известный шведский ученый, профессор Якобеус, изобретатель торакоскопа, скоропостижно скончался 29 октяб́ря 1937 г. в возрасте 58 лет.

122) Нlacеление земиого шара в 19.6 г. составляло согласно переписям и полспетам постеднего врсмени 2116 миллионов. Мз әтоло числа больше половины (1162 мил.) триходится на Азию, четверть (526 мил.)-ла Евролу и одна восьмая часть (266 мил.)-на Америку На I кв. километр придодится в Европе 46 жителей, в Азич- 28 , в других частях света- $-5,2$

123) Количество зарегистрнрованных случаев профессиональных заболеваний было в Германии в 1936 г. на 10,8\% больше, чем в 1:35 г., а в 1935 г. на 13\% выше, чем в 1933 г. Вознаграждение по поводу профессиолального заболевания было выдано лишь в 22 слупаях; в том числе было 113 снучая смерти.

124) Венгерское лрзвительство издало несколько лет тому назад, в интересах виноделов, распоряжеиие, согласно которому каждый солдат полудает ежедневно поллитр: вина. Со времени нздания этого закона положение в винодельческой промышленности не улүчцилось, а ухудшилось. В целях дальнейшей помоци виподелам, вр.вительство недавно раслорядилось, чтобы в ресторанах при еде подавалось вино, лезависимо от того, желаег ли этого потребитель нли не желает. Хорошо ещс, пишет Велгерский медицинский журнал, поо правительство не приназало выдавать вино детям вместо молока.

125) Алкоголизм среди школьников в Германии. Обследование более 5000 школьников в Вюртемб́ерге показало, что $75 \%_{0}$ из них привыкли употреблять алкозольные налитк. 19\% пьют их ежедневно. Почти тысяча школьников сообщили, што и младшие их братья и сестры употребляют спиртные напитки. -аще всего дети пьюг молодое вино, которое, как известю, сољержит довольно высокий процент алкоголя: второе место заниміет пиво.

126) В Париже имеется в частных домах 27.256 газоубежищ на 17200 со человек, два газоубежища на 4-5 тысят человек каждос находятся в подземной железной дороге и строятся повые газоубенища еще на 5 жо 0 человек. В јраге строится подземный госпиталь, зацицениы й от газов и брпзантых снарядов. В Ангии изучается вопрос, нельзя ли использовать в качестве газоубежищ имеющиеся в стране многочисленые пешеры и гроты, а заброщенные каменноугольные шахты предполагается использовать в катестье складов для лищевых продуктов. 


\section{ОБ Я Я А ЕН ИЯ}

Алатырской райбольнище Чувашской $\mathbf{A C C P}$ требуется врач акушер-гинеколог на 30 кэек родильного отделения, со стажем же менее 3 лет ординаторской работы в клинике или в крупной больнице.

Ставка по закону от 4/III 1935 г.

Подъемные по 82 ст. ЗКТ.

Предоставляется квартира.

Автобиографию и копии с трудового списка направлять: г. Алатырь ЧАССР. Глав. врачу нарбольницы.

НАРЫМсКИЙ ОКРЗДРАВОТДЕЛ Приглашает санитарных и лечащих врачей всех специальностей, фармащевтов, оканчивающих молодых врачей и средний медперсонал на службу в благоустроенные районные участковые больницы, роддома, детконсультации, медпункты и аппараты здравотделов.

Оплата труда согласно пост. СНК СССР от 4/III 1935 г. плюс $50 \%$ надбавки за отдаленность.

Коммунальные услуги предоставляются бесплатно натурой (квартира, отопление, электрическое освещение).

Проєзд к месту службы по закону КЗОТ обеспечивается полностью.

В особо отдаленных медточках по договоренности устанавливается персональная ставка.

В окружной центр Колпашево требуется: врач первой помощи, инфекционист, хирург, гинеколог, рентгенолог, энтомолог, невропатолог, физиотерапевт и рентгено-физиотехник.

Заявления почтой или телеграфно направлять по адресу Колпашево, Нарымскому Окрздраву Новосибирской области.

Лечпрофотдел окружного отдела здравоохраненкя. 


\section{Оглавление XX:III тома за $1937 \mathrm{r}$.}

A.

Абрамович И. А. и Фой А. М. (Ленинтрад). Обезболивание родов в начале периода раскрытия : . . . . . . . . . .

Агринский М. Е. (Сталинград). K клинике брюшного тифа у вакцинированных

Адамов Г. П. и Дыхно А. М. (Ростов н/Д). К вопросу о солитарных

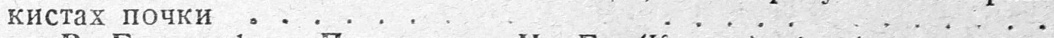

Адамюк В. Е., проф. и Пастернак Н. Г. (Казань). Атуберкулиновый антивирус Мазура в терапии скрофулезных и туберкулезных поражений органа зрения

Алеутская С. И. (Иваново). Аммиачные растворы солей серебра при лечении женской гонореи

Астраханов А. И., Глозман О. С., Белокопытова Э. Н., Демидова 3. Г. (Саратов) К вопросу о лабораторной диагностике активности туберкулезного процесса..............

Афанасьев Д. В. (Ташкент). Кислородная терапия психозов

Афанасьев Д. В. (Ташкент). Опыт лихорадочной терапий хронических энцефалитиков ... . . . . . . . . . . . . . . . .

Афанасьев Д. В., доц. (Ташкент). Нервно-психические явления при лихорадке паппатачи

5.

Багров Ю. Б. (Златоуст). К методике оперативного лечения мозговых

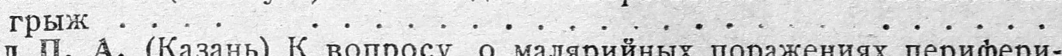

Бадюл ПI. А. (Казань) К вопросу о малярийных поражениях периферической нервной системы

Балахнин Н. Ф. (Соликамск). Ртутный пластырь при лечении хронических язв голени .. . . . . . . . . . . . .

Балахнин Н. $Ф$. (Соликамск). Итоги лечения массивными дозами гонококковой вакцины - Л. - .

Баркан М. Б. (Москва). Легочные абсцессы по материалам МОКИ за

Басыр $\Phi$. Х. (Казань). Переливание крови в клинике детских болезней

Белов В. Н. (Даурия). Лечение әрозий шейки матки рыбьим жиром.

Белокопытова Э. Н., Глозман О. С., Астраханов А. И., Демидова 3. Г. (Саратов). К вопросу о лабораторной диагностике активности туберкулезного процесса

Бикчурин III. В. и Еселевич Э. И. (Казань). К вопросу о повреждениях нервных стволов при внутримышечных инъекциях .

Биншток М. А. И Мариалкович Д. Б., проф. (Одесса). О применении топинамбура в диете диабетика .............

Благовидов $\Phi$. Я. (Казань). К казуистике внутренних грыж брюшной полости . . . . . . . . . . . . .

Благовидов Ф.. Я. (Казань). К казуистике инородных тел пищевода :

Бобинская Г. А. и Максутова М. Х. (Казань). Материалы по изучению пневмоний детского возраста ...........

Боговаров К. И. и Сегень Е. Б. (Казань). Наблюдения над основным обменом при сердечно-сосулистой недостаточности . . . . . . 
Бондарчук А. В. (Ленинград). Случай пластики сальником при повреж-

Бондарчук А. В. (Акимовка, Днепропетр. обл.). О применении гуманоля для лечения гнойных ран И. (Омск). Лечение переливанием крови

Борисов Н. А. и Вахрамеев П. И. (Омск). Лечение переливанием крови
помутнения стекловидного тела . . . . . . .

Брейтман M. Г. (Бершадь). К технике пересадки мочеточников в кишку

Бритван Я. М. (Одесса). Феномен Чейн-Стокса и его отношение к другим расстройствам ритма дыхания

Бритван Я. М. и Графф А. А. (Одесса). Периодические расстройства ритма дыхания при остром повторном кровотечении

Бродский О. А. и Корыткин-Новиков Л. Е. (Одесса). Хронические абб-

Брук А.И. и Либерман Щ. И. (Харьков). Рентгенотерапия 12-перстной

Будина Р. Я., доц. и Гольдельман М. (Киев). K клинике травм спинного мозга

Булгач Р. А. (Днепропетровск). К казуистике множественного осложнения при наложении искусственного пневмоторакса

Бух Ф. Л. (Киев). Феномен Шварцмана, вызываемый сопутствующей

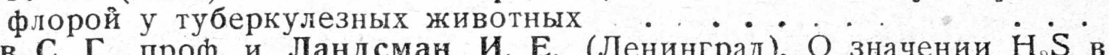

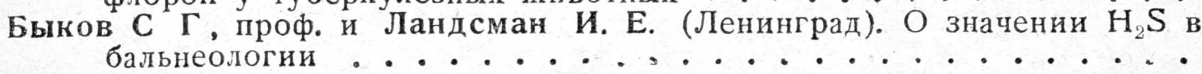

Вайндрах Г. М. и Фадеева С. В. (Москва). Картина крови при септической (агранулоцитарной) ангине

Вайнштейн А. С. (Москва). Об антигенных свойствах неосальварсана:

Вахрамеев П. И. и Борисов Н. А. (Омск). Лечение переливанием крови помутнения стекловидного тела

Beйс А. С., доц. (Казань). Лечение золотушных кератоконъюнктивитов атуберкулиновым антивирусом .

Велькер И. И. (Энгельс). Опыт лечения хронических остеомиелитов по Лэру

Венгеровский И. С. (Москва). Роль травмы в возникновении гематогенного остеомиелита у детей

Вербов А. Ф., проф. (Ленинград). Методика физкульттерапии заболеваний органов движения в условиях стационара

Винник Р. Д. (Одесса). Случай аденомы червеобразного отростіка . . .

Винокур Я. И. (Свердловск). Бруцеллезный ишиас

Вигдорчик Н. А., проф. (Москва). Наблюдения из области медицинской профконсультации . . . . . . . . . . . . . . . . . . .

Вилесов С. П. и Любина Н. И. (Казань). О лечении циститов хлорацидом

Виноградов А. С. (Казань). К клинике рака пищевода . . . . . . .

Вознесенский С. Д. (Москва). Динамика анимально-вегетативных рефлексов у туберкулезных в процессе эмоциональной мототерапии

Воловик А. Б., проф. (Ленинград). Ревматические пульмониты у детей

Воскресенский Г. ПІ. (Саратов). Случай кифоза после столбняка . . .

Вяселева С. М. (Казань). К вопросу о влиянии активной иммунизации на носительство дифтерийных палочек .

Вяселева С. М. (Казань). К оценке бактериологической диагностики дифтерии по методу Фольгер-Золе

\section{$\Gamma$}

Габай А. В. (Запорожье). К симптоматологии острых аппендицитов н острых брюшных выпотов

Галиновская С. И. (Сталинград). Опыт применения диатермии в лечении гипофункции яйников

Гаранкина С. П. (Казань). Случай одновременной маточной и внематочной (трубной) беременности 
Гельтцер О. В. (Казань). О применении основной пнтательной среды из творога для выращивания микробов . . . . . . . . . .

Герасимов И. Ф. (Елабуга АТССР). О язычном зобе ..... .

Герб Э. Ф. и Липовецкая Е. Н. (Саратов). Инфильтративные формы тбк $\mathrm{y}$ детей

Геринштейн И. М. (Кирово). Случай lithopädion четырехлетней давности . . . . . . . . . .

Гертман 3. А. (Казань). Диагностическое значение реакции БухштабаЯсиновского у детей-ревматиков

Герцберг Б. Г., проф. (Казань). Прободная язва желудка и 12-перстной кишки по данным хирургического отделения Обуховской им. Нечаева больницы в Ленинграде

Гетов Ф. А. и Иершевский Б. М. (Кисловодск) Изменения минутного опорожнения сердца под влиянием углекислых (нарзанных) ванн .

Гинзбург Б. С., доц. (Казань). Казанский государственный институт усовершенствования врачей им. В. И. Ленина к XX годовщине Октября

Глаголев С. И. (Свердловск). К вопросу об эмболиях венечных сосудов

Глозман О. С., Астраханов А. И., Белокопытова Э. Н., Демидова З.Г. (Саратов). К вопросу о лабораторной диагностике активности туберкулезного процесса

Глюзман М. А. (Баку). Посгроение рационального питания при острых гепатитах

Голиков А. И. и Григорьева М. М. К вопросу о лечебном значении перекармливпия нефротиков белками

Головань Е. П. и Израэльсон М. М. (Одесса), Реакция связывания комплемента на сифилис с экстрактом из бледной спирохеты . . .

Голосовкер С. Я., проф. (Свердловск). Эпидермофитня ........ .

Голубов Н. Ф., заслуж проф. (Ялта). О некоторых невро-вегетативных явлениях со стороны печени .

Гольдельман М. и Будина Р. Я., доц. (Киев). К клинике травм спинного мозга

Гольдштейн Д. Е., Лейзеровская М. О и Тямина Г. С. (Казань).

Гольдштейн Л. Н. (Саратов). К вопросу об обработке культи червеоб-

разного отростка при аппендектомии .
Гордиенко А. Н. и Старосветская 3. Б. (Краснодар). Влияние пищевого режима на феномен Артюса.

Гордиенко А. Н. (Краснодар). Роль нервной системы в сокращении гладкой мускулатуры при анафилаксии . . . . . . . .

Гордиенко А. Н. и Шиманский (Краснодар). Действие сыворотки на денервйрованную лапку

Графф А. А. и Бритван Я. М. (Одесса). Периодические расстройства ритма дыхания при остром повторном кровотечении . . . . . .

Григорьева М. М. и Голиков А. И. К вопросу о лечебном значении перекармливания нефротиков белками

Григорьев П. С., проф. (Саратов). Новый способ лечения стригущего

Гриневич Д. А. и Левин Я. Ф. (Харьков). О клинико-рентгенологической картине актиномикоза легких

280

1476

899

904

191

132

Груздев В. С., заслужен, деятель науки, проф. (Казань). К вопросу о радикальном лечении фибромиом матки

Гуревич Л. И. и Николаев А. П., проф. (Сталино-Донбасс). Лечение воспалений женской половой сферы парентеральным введением минеральных вод

Гуревич Т. 3. (Москва). Клинические наблюдения над скоростью кругооборота крови при помощи внутривенного вливания хлористого кадьция

Гурвич Е. Я. (Ленинград). Опыт лечения сердечной декомпенсадии видоизмененным карелевским режимом .

Гутман Г. А. (Чебоксары). Случай задержания костей плода в полости матки после аборта в течение шесіи лет. 


\section{$-1522-$}

Д

Давыдов В. И. (Омск). Простейший способ определения положения

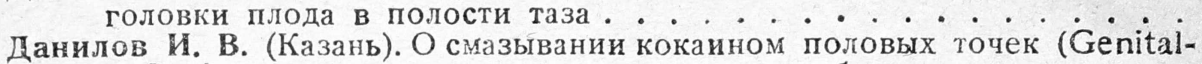
stellen) в носу при дисменоррее и родовых болях - $\cdot$ -

Демб И. Г. (Тобольск). Опыт антисептической (холодной) обработкн перчаток

Демидова 3. Г., Глозман О. С., Астраханов А. И., Белокопытова Ә. Н. (Саратов). K вопросу о лабораторной диагностике активности туберкулезного процесса . . . . . . . . . . . . . . . . .

Джапаридзе Б. С. (Сигнах, Грузия). Камень желудка ..........

Домрачев И. В., проф. (Казань). Результаты амбулаторного лечения новокаиновыми инъекциями больных по материалу 3-й (Плетеневской) рабочей больницы г. Казани . . . . . . . . . . . . . . .

Драбкина Р. О., доц. (Киев). К вопросу о механизме феномена Бордэ

Дунье М. В. (Полоцк БССР). К казуистйе ущемленных грыж Дугласова пространства

Дунье М. В. (Полоцк). Самопроизвольная гангрена наружных гениталий

Дыхно А. М. и Адамов Г. ПІ. (Ростов н/Д). К вопросу о солитарных кислотах почки

Дыхно А. М. и Ольштей С. Е. (Ростов н/д). О качестве хирургической струны

E

Eгерева С. А. (Казань). К клинике и лечению токсической дифтерии

Емелина А. В. (Саратов). К вопросу о дерматозах беременности . . . .

Ерзин М. А. (Казань). Динамика колебаний глютатиона при экспери-

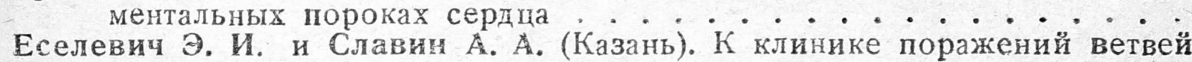
задней мозговой артерии

Еселеви Э. М. и Бикчурин И. В. (Казань). К вопросу о повреждениях
нервных стволов при внутримышечных инъекциях . . . . .

Еселевич Э. И. и Бикчурин Щ. В. (Казань). К вопросу о повреждениях
нервных стволов при внутримышечных инъекциях . . . . .

\section{Mำ}

Жолондзь А. М. (Ленинград). Сравнительная оценка способов оперативного ленения задних маргинальных переломов большеберцовой кости на основания анализа сосудистого снабжения . . . . . . .

\section{3}

Зайцев А. А. (Ленинград), О леченин самопроизвольной гангрены плацентарной кровью . . . . . . . . . . . . . . . . . . . .

Зальцберг А. А. (Одесса). Случай бруцеллеза в комбинации с трехдневной малярией

Звоницкий Н. С., проф и Юрина А. Н. (Москва). Клиническая иллюстрация к синдрому вегетативно-дискинетической желтухи . . . . .

Зенин А. С. проф. (Куйбышев). Случай раннего врожденного сифилиса

Золотарева М. М. и медведев H. И. (Сталино) К клинике Renitis albuminurica gravidarum.

Нванов А. Я. (Нежин) К вопросу о закрытых повреждениях органов брюшной полости . . . . . . . . . . . . . . . .

Ивашиненко В. А. и Харизоменова Е. С. (Сталинград). Влияние кумыса на моторную функцию желудка . . . . . . . . . . . .

Израэльсон M. M. и Головань Е. П. (Одесса). Реакция связывания комплемента на сифилис с әкстрактом из бледной спирохеты.....

Ишмухаметова Г. 3. (Казань). О влиянии десенсибилизирующей терапии на клеточковую реакцию организма 
Какубава К. А. (Очемчиры, Абхазия). Два случая заворота слепой кишки . . . . . . . . . . . . . . . . . . . . .

Каменорович Б. У. (Томск). Случай әхинококка левой почки . . . .

Каменский Е. А. (Ессентуки). Динамика рельефа при хронических воспалениях слизистой желудка в оценке лечебного әффекта . . . .

Канторович П. И. и Рахманчик Л. И. (Минск). Переливание плацентарной крови при раковых заболеваниях матки

Каплан А. Л. (Москва). ІІо поводу статьи проф. П. В. Маненкова „К вопросу о радикальном лечении фибромиом матки“ . . . . . . .

Каралис В. В. и Студницын А. А. (Москва). Опыт применения миарсенола при лечении сифилиса..................

Карташев П. Н., проф. (Саратов). О дистрофических процессах при введении разлитнд раздражителей в периферические ветви тройничного нерва

Кейлин С. Л. (Свердловск). Обследование полости послеродовой матки.

Кессель $\Phi$. К. (Воронеж). К вопросу о капсюльных ранениях . . . . .

Кечек Ә. К. (Ростов н/Д). Ostitis fibrosa cystica localisata.

Ковязин Н. (Казань). К вопросу о лечебном действии конваллена при сердечно-сосудистых заболеваниях . . . . . . . . . . . . . .

Ковязин Н. Н. и Копырин С. А. (Казань). К лечению колитов и гастритов аммиачными соединениями серебра

Koraн Д. А. (Ленинград). Морфологическая конституция и язвенная болезнь . . . . . . . . . . . . . . . .

Коган С. А. (Горький). О клинической ценности реакции Бухштаба и Ясиновского в диференциальной диагностике ревматизма

Козмодемьянский Г. И. (Казань). Лечение пиодермий лучистой энергией искусственных источников света....... . . . . . . .

Колачев А. А. (Щахты). О легочном раке у углекопов .....

Кондратьев Г. Г. (Казань). Реактивность кожи сенсибилизированных животных на воздействия микроорганизмов

Константинов В. Н. (Киев). Применение гипноза в хирургии . . . .

Копырин С. А. и Ковязин Н. Н. (Казань). К лечению колитов и гастритов аммиачными соединениями серебра ... . . . . . . .

Коробков Л., проф. (Иваново). Два случая геморагического плеврита .

Коробков Л., проф. и Чернышев В. (Иваново). Случай гнойного плеврита

Корчагина Н. А. (Казань). Лечение гинекологических больных на курорте Бакирово АТССР

Корыткин-Новиков Л. Е. и Бродский О. А. (Одесса). Хронические абсдессы грудной железы

Коф̆ман С. В., проф. (Ташкент). О ранних симптомах заболевания позвоночника туберкулезом ... .

Краснова А. И. (Саратов). Лечение трихомонадных колынтов хлорацидом .

Куденко И. Д. (Москва). Случай обратного перемещения внутренних органов в сочетании с Бремеровской дистрофией

Куденко И. Д. (Москва). Комбинированная электро-тимо-лизатотерапия при базедовой болезни и гипертиреозах.

Курьянова Е. М (Казань). К вопросу о выращивании гонококка на средах без асцитической жидкости

Кушев Е. Н., проф. (Саратов). Самонаблюдение врача над старостью. .

\section{л.}

Ландсман И. Е. и Быков С. Г., проф. (Ленинград). О значении $\mathrm{H}_{2} \mathrm{~S}$ в бальнеологии

Лебедев В. E (Саратов). Хирургическое лечение фибромиом матки :

Лебедевский Б. Н., проф. (Пермь). Из практики бронхо-эзофагоскопии.

Левин Я. Ф. и Гриневич Д. А. (Харьков). О клинико рентгенологической картине актиномикоза яегких 
Лейзеровская М. Е., Михлина Э. Е., Милованова Н. Н. (Казань).

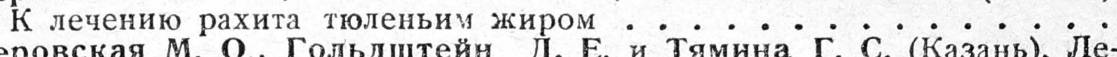

Лейзеровская М. О., Гольдштейн Д. Е. и Тямнна Г. С. (Казань). Лечение рахита витаминолем . . . . . . . . . . . . . . .

Лейзеровский А. М. (Казань). Случай симметрической кератодермии с резко выраженными изменениями вегетативной нервной системы .

Лепский Е. M, проф. (Казань). О ранней диагностике авитаминозов . •

Лепский Е. М., проф. и Ратнер А. А. (Казань). О профилактике и лечении рахита диетой

Либерман Ш. И. и Брук А. И. (Харьков). Рентгенотерапия 12-перстной кишки

Либов А. Л. (Ленинград). О методике борьбы с энтеротропными инфекциями

Липовецкая Е. Н. (Саратов). Әндоназальный метод применения туберкулинотерапии у детей

Липовецкая Е. Н. и Герб Э. (Саратов). Инфильтративные формы тбк у детей

Литвак Л. Б. (Харьков), Общие проблемы ото-офтальмоневрологии и роль височной доли

Любина Н. И. и Вилесов С. П. (Казань). О лечении циститов хлорацидом .

M.

мазур Б. Л., проф. (Казань). О типах туберкулезных бацилл в свете учения о диссоциации

759

1494

Макаренко В. А. (Ростов н/Д). О кормлении больных при гастротомии.

Малкин 3. И., проф. (Казань). Проб́лема эндокардитов в связи с учением об алергии

Максутова M. Х. и Бобинская Г. А. (Казань). Материалы по изучению пневмоний детского возраста

680

268

387

1454

702

308

994

Мальковский Г. М. (Воронеж). Влияние Сергиевских минеральных вани на проницаемость капиллярных сосудов кожи и гидрофильность ткани

Маненков П. В., проф. (Казань). Ответ на статью доц. А. Л. Каплан „По поводу статьи проф. П. В. Маненкова „К вопросу о р.дикальном лечении фибромиом матки“

Мариупольский Р. М. (Свердловск). Лечение сифилиса осарсолом -
Мартынюк А. Г. (Харьков). К вопросу о расширении вен верхних конечностей

Маршалкович Д. Б., проф. и Биншток М. А. (Одесса). О применении топинамбура в диете диабетика

Медведев Н. И. и Золотарева M. M. (Сталино). К клинике Renitis albumi u ica gravidarum

Месик Р. Е. и Пайн Э. Я. (Москва). О своеобразной дизентерии, вызванной палочкой паратифа В

милованова Н. Н., Михлина Э Е., Лейзеровская М. Е. (Казань). К лечению рахита тюленьим жиром

Мильман И. С., проф. и Рогинская С. С. (Днепропетровск). Әкспериментальиые исследования о дискератозе кожи

Михайлов В. И. и Мухамедьяров Г. И. (Казань). Результаты хирургического лечения язв желудка и 12-перстной кишки

михлина Э. Е., Лейзеровская M. Е., Милованова Н. Н. (Казань). К лечению рахита тюленьим жиром

мустафина Х. А. (Казань). Опыт лечения чешуйчатого лишая внутривенными вливаниями гипосульфита

мухамедьяров Г. И. (Казань). Случай двойной самоампутации червеобразного отростка слепой кишки .

Мухамедьяров Г. И. и Михайлов В. И. (Казань). Результаты хирургического лечения язв желудка и 12-перстной кишки

Мясников К. Е. (Казань). О клиническом значении исследования морфологического состава кантаридинового пузыря при алергических состояниях 
H.

Нарышкина 3. П. (Москва). Бактериофаг как терапевтическое средство при дизентерии .

Невский А $\mathrm{H}$. (Катач) Кишечная (Аеноходимост. . . . . .

Нестерова А. И. и Шейман А. И (Астрахань). К клинике сирингопиемии.

Николаев А. П., проф. (Сталино-Донбасс). О хорионәпителиоме

Николаев А. П., проф. и Гуревич Л. И. (Сталино-Донбасс). Лечение воспаления женской половой сферы парентеральным введением минеральных вод ...............

Новиков В. А. (Казань). Описание термопары для исследования кожной температуры методом гальванометрии

Новиков В. А. (Казань). Первый советский томограф . . . . . . . 1376

0.

Оделевская Н. Н. (Казань). Опыт сличения диагнозов амбулаторных (направительных) и стационарных (заключительных) .........

Ольшинский $Ф$. М. (Киев). Реакция Бускино при внутренних заболеваниях

Ольштейн С. Е. и Дыхно А. М. (Ростов н/д). О качестве хирургической струиы

омороков Л. И., пр ф. (Казань). О Кожевниковской әпилепсии травматического происхождения и о значении травмы в рззвитии эпилепсии

Орлов М. М. (Севастополь). О ревматической этиологии эндартериита . .

Осипова М. Л. (Казань). Случай заражения сифилисом при переливании

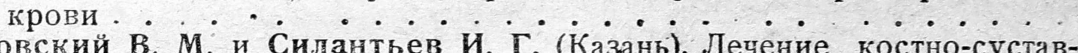

Осиповский В. М, и Силантьев И. Г. (Казань). Лечение костно-суставного туберкулеза в практике участковой больницы

Осиповский В. М. (Казань). Новокаиновый блок по Вишневскому как метод лечения отрлвления змеиным ядом ............

Отвиновская 3. Е. и Успенский Б. В. (Оренбург). Тифоподобные заболевания с палочкой Гертнера в крови .............

1424

I.

Пайн Э. Я. и Месик Р. Е. (Москва). О своеобразной дизентерии, вызван-

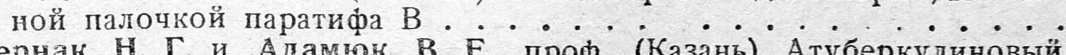

Ластернак Н. Г. и Адамюк В. Е., проф. (Казань). Атуберкулиновый антивирус Мазура в терапии скрофулезных и туберкулезных поражений органа зрения

Перлин М. С., Эльяиев А. И., Цюрло Э. А. (Ленинград). О воздействий некоторых веществ на регенерацию костной ткани . . . . . . . .

Першин А. Г. и Филинов Н. Е (Сочи). К вопросу о клиническом значении опреде"ения скорости кругооборота крови у сердечно-сосудистых больных

Перчук Р М. и Попоs И. И. (Одесса). Испытания сердечно-сосудистой системы у лиц, подверженных морской болезни . . . . . . . . .

Петерсон В. С. и Рубашкина Б. К. (Саратов). Случай септического заболевания, вызванного B. pr. teu;

Петров Б. Н. (Тамбов) К вопросу об активной иммунизации против ветряной оспы •. . . . . . . . . . . . . . . . . .

Петров С. И (Казань). Медицинская кровать для предупреждения и лечения пролежней, гангрены и ля облсгчения состояния больных

Петровых В. А. (Советская гавань, ДВК). Лєчение обморожений открытым способом (без перевязок) . . . . . . . . . . . .

Платов В. Н. (Москва. Опыт применения моновалентных сывороток в терапии эпидемическото менингита . . . . . . . . . . .

1226

470

255

140

1491

Покомарев П. Е. (Шахты). Случай рецидивирующей хореи в связи с введением противодифтеритной сыворотки 
Пономарев П. Е. (Толдом). К вопросу о малярийных психозах . • . • •

Попов В. Н. (Казань'. УІрощенный способ выращивания анаэробов в пластинчатой культуре . . . . . . . . . . . . . . . .

попов И. И. и Перчук Р. М. (Одесса). Испытания сердечно-сосудистой системы у лиц, подверженных морской болезни

1407

Попов Н. И. (Казань). Проницаемость гематоэнцефалического барьера для нодистого натрия при некоторых органических заболеваниях

нервной системы
Потехин Д. Е. и Яльцев П. Д. (Казань). Рентгенотерапия хронического грина

\section{P}

Равикович А. У. и Шмундак Д. Е., проф. (Днепропетровск). Витальная окраска гомологичных органов при введении лизатов . . . . .

Рабовская А. Е. (Запорожье). К вопросу о некрозе тканей после местнй анестезии новокаином

рапиовец В. Л. (Сталинград). Случай повышенной чувствительности к плазмоциду .

Ратнер А. А. и Лепский Е. М., проф (Казань), О профилактике и чении рахита диетой

ратнер Е. A. (Ленинград). Что такое гомеопатия

рахманчик Л. И. и Канторович П. И. (Минск). Переливание плацентарной крови при раковых заболеваниях матки . . . . . . . . . . .

Репин Г. Я. (Астрахань). Масса крови при малярии

Рифман М. А. (Казань). О влиянии токсических доз плазмоцида на нервную систему

рогинская С. С. и Мльман И. С., проф. (Днепропетровск). Экспериментальные исследования о дискератозе кожи

родионов В. Е. (Арда А. $\Phi$. и Знверт К. Н. (Томск). Трансфузия крови при кожных заболевания $\mathrm{x}$

Рубашкина Б. К. и Петерсон В. С. (Саратов) Случай септического заболевания, вызванного B. proteus

Руссков Н. В. и Степуховкч Д. М (Кисловодск). Хрं причина тромбоза нижней полой вены

C.

Сандуковский И. Э (Полтава). О подкожных разрывах селезенки . . .

Cereнь Е. Б. и Боговаров К.И. (Казань). Наблюдения над основным обменом при сердечно-сосудистой недостаточности . . . . . . . . . .

Сегень Е. Б. (Казань). О влиянии сарабикуловских сероводородных ванн на динамику глютатиона у сердечно-сосудистых больных . .

Серебренников Н. А. (ст. Ртищево, Р.-У. Ж. д.). Случай фиброзной остеодистрофии

Силантьев И Г. и Осиповский В. М. (Казань). Лечение костно-суставного туберкулеза в практике участковой больницы . . . . . . .

Сиротинин Н. Н., проф. (Киев). Аллергия при туберкулезе . . . . . .

Славин А. А. (Казань). К симптоматологии поражений conus meduliaris

Славин А. А. и Еселевич Э. И. (Казань). К клинике поражений вегвей задней мозговой артерии

Случевский И. С. (Калинин). Лечение острого ревматизма стрептоцидом

Сойников В. В. (Харьков . Условия физико-химических и биологических явлений в поле ультракоротких волн ....... . . . . . .

Соколова Н. С. (Тетюши). Случай отшнуровавшейся дермоидной кисты

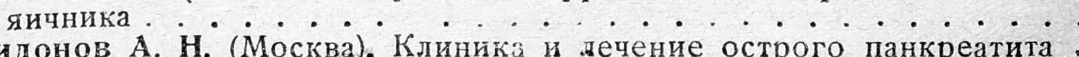

Спиридонов А. Н. (Москва). Клиника и .ечение острого панкреатита -
Старосветская 3 Б. и Гордиенко А. Н. (Краснодар). Влияние пищевого режима на феномен Артюса . . . . . . . . . . . .

Степухович Д. М. и Руссков Н. В. (Кисловодск). Хрониосепсис как причина тромбоза нижней полой вены . 
Степухович Д. М. и Щершевский Б. М. (Кисловодск). Изменения количества циркулирующей крови под влиянием углекислых (нарзанных ванн . . . . . . . . . . . . . . . . . . .

Студницын А. А. и Каралис В. В. (Москва). Опыт применения миарсенола при лечении сифилиса

Суворов B. A. (Казань). Экспериментальные данные о судьбе погруженной и непогруженной культи слепого отростка толстой кишки у собак......................

Суворов В. А. (Казань). О перфорациях язвы желудка при рентгеноскопии . . . . . . . . . . . . . . . . . . . .

Сулиовская Н. А. и Улицкая Э. М. (Харьков). Определение количества циркулирующей крови во методу Марковица (с помощью определения сахара крови до и после внутривенного вливания глюкозы)

\section{T.}

Талантов В. И. (Казань). Исследование реакции кожных капилляров на травматйзацию при заболевании внутренних органов. . . . . .

Тарабухин А. А. (Москва). Стоматит и ангина Венсан-Плаута . . . .

Татаров А. ПІ., доц. (Архангельск). Влияние кислорода на организм животных и людей при курсовом подкожном применении . . . . .

Терегулов А. Г., проф. (Казань). К патогенезу и клинике нефрозов .

Терегулов А. Х. (Казань). К вопросу о возбудимости блуждающего нерва у собак в связи с местным давлением на большой мозг при остром опыте . . . . . . . . . . . . . . . . . .

Трутнев В. К., проф. (Казань). Об инородных телах трахеи и бронхов ,

Тямина Г. С., Гольдштейн Д. Е. и Лейзеровская М. О. (Казань). Лечение рахита витаминолем

\section{$y$.}

Улицкая Э. М.и Сулимовская Н. А. (Харьков). Определение количества циркулирующей крови по методу Марковица (с помощью определения сахара крови до и после внутривенного вливания глюкозы)

Успенский А. Д. (Новые Горки, И. П. О.). Абортная масса как пласти-

Успенский Б. В. и Отвиновская 3. Е. (Оренбург). Тифоподобные заболевания с палочкой Гертнера в крови ...........

Устиновский А. В. (Москва). Лизатотерапия при кожных болезнях . .

\section{ф.}

Фаддеева С. В. и Вайндрах Г. М. (Москва). Картина крови при септической (агранулоцитарной) ангине .............

Фадеев И. П. (Казань). О повреждениях черепа в состоянии опьянения

фельдман В. И. (Москва). IV Всесоюзный съезд по борьбе с венерическими и кожными болезнями ............ . . . . . .

1065

$1: 87$

787

Филинов Н. Е. и Першин А. Г. (Сочи), К вопросу о клиническом значении определения скорости кругооборота крови у сердечно-сосу-

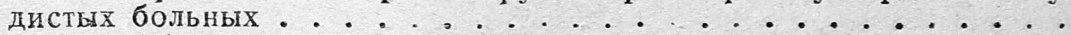

Фой А. М и Абрамович И. А. (Ленинград). Обезболивание родов в натале периода раскрытия

фурман A. C (Москва) Легочный туберкулез и вегетативная нервная система

\section{$\mathbf{X}$}

Харизоменова Е. С. (Саратов). Кумысолечение при желудочно-кишечных заболеваниях

Харизоменова Е. С. и Ивашиненко В. А. (Сталннград). Влияние кумыса на моторную функцию желудка

Хлюпин П. И (Энгельс). К вопросу о переломах тазового кольца и вывихе одной половины таза. 
4.

Цирулик Г. Л. (Могилев). Острая ложная диафрагмаяьная грыжа . . . .

Цюрло Э. А., Эльяшев А. И., Перлин М. С. (Ленинград). О воздействии некоторых вещесте на регенерацию костной ткани. . . . . .

\section{4.}

Черных Г. С. (Ижевск), Случаи камкя носовой полости . . . . . . . 1385

Чернышев В. и Коробков Л., проф. (Иваново). Случай гнойного плев-

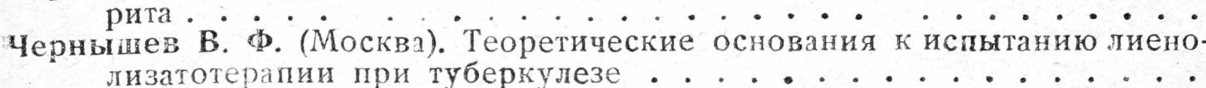

L1.

Шалагин М. М. (Казань). О разрывах малярийной селезенки • • • • • • Шамарин П. И. (Саратов). К клинике и цитологии гемоторакса • . • • Jayфлер K. K. (Саратов). Новое антисепгическое средство "хлорацид" Шейкин А.И. (Астрахань) К вопросу об острой спонтанной инфекции нервной системы . . . . . . . . . . . . . . . . Иейкин А. И. (Астрахань). Микродозы брома при неврозах . . . •. . Шейкин А. И. (Астрахань). Лизатотерапия при заболеваниях нервной си-

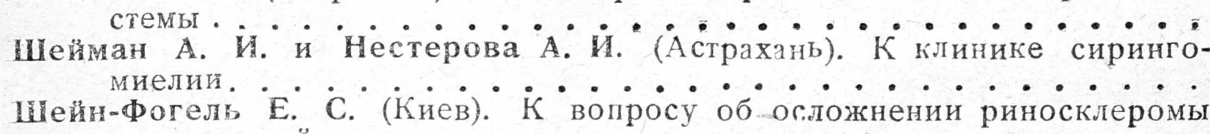

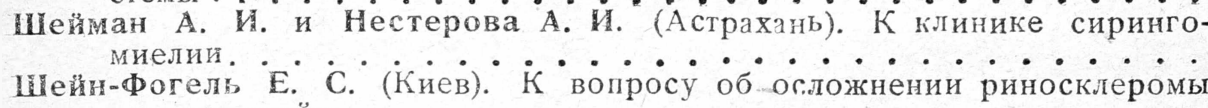
эпителиомой

Икляев В. В. (Омск). Изолированный перелом ладъевидной кости за-

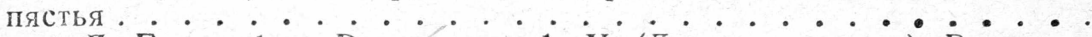

Шиундак Д. Е. проф. и Равикович А. У. (Днепропетровск). Витальная окраска гомологичных органов при введении ли атов .

штерн Л. С., засл. деят. науки, проф (Москва). Роль метаболитов и роль гисто-гематических барьеров в регуляции функций организма

Иулутко Л. И., доц. (Казань). Наблюдения над лечением некоторых форм костного туберкулеза антивирусом Мазура..........

Шиарин А. С. (Воронеж). Случай перекручивания фиброматозной матки. Икляев А. А. (Челны). О так называемом аппендикулярном симптомокомплексе при мал рии . . . . . . . . . . . . . . . . . . . .

Шкляев В. В. (Омск). Случай развития эхинококковой кисты в операционном рубце после эхинококкотомии

11ершевский Б. М. и Степухович Д. М. (Кисловодск). Изменения количества циркулирующей крови под влиянием углекислых (нарзанных) ванн . . . . . . . . . . . . . . . . . . . .

Шериевский Б. М. и Гетов Ф. А. (Кисловодск). Изменения минутного опорожнения сердца под влиянием утлекислых (нарзанных) ванн .

Шиманко И. И. (Москва). Кожный туберкулез и алергия . . . . . . .

Ииманский и Гордиенко А. Н. (Краснодар). Действие сыворотки на денервированную лапку

\section{II.}

Щербатов И. И. (Казань). II поволжская конференция рино-ларингоотиатров ........................

Әльяшев А. И., Перлин М. С., Цюрло Э. А. (Ленинград). О воздейст-

вии некоторых вецеств на регенерацию костной ткани . - . .
Энтин Н. А. (Витебск). Ранний симптом инфицирования герниотомной раны 
10.

Юрина А. И. и Звоницкий Н. С., проф. (Москва). Клииическая иллюсрация к синдрому вегетативно-дискинетической желтухи . . . . .

Юринов Т. М. (Брянск). Применение сериокислой магнезии для лечения эссенциального недержания мочи . . . . . . . . . . . . .

ต.

Яльцев П. Д. (Казань). Рентгенотерапия гидродденитов . . . . . . . . 858

Яльцев П. Д. и Потехин Д. Е. (Казань). Рентгенотерапия хронического грипа

\section{Обзоры:}

Гасуль Р. Я. (Казань). Второй украинский съезд рентгенологов и радио-

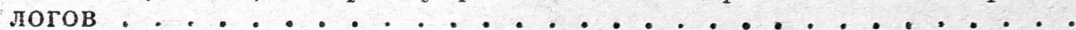

Гитис Д. О. (Киев). Проблема аммилка в клинике ...........

Грязнов И. С и Богоявленский В. М. (Москва). Ботулизм . . . . .

Дмитриев А. И. (Мос $`$ ва). Всесоюзная конференция урологов .....

Коробков Л. И. (Саратов). Значение осмотра в диагностике внутренних болезней

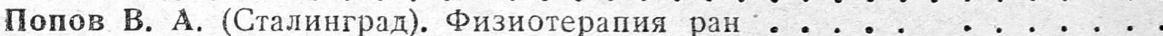

Российский Д. М., проф. (Москва). Грипозная проблема по работам сессии Ученого медицинского совета Наркомздрава РСфСР . . . . . .

Фоменко Б. П. (Ленинград) K вопросу о применении наружного поворота при ягодичном предлежании

Библиография и рецензии ๑109, $928,1284,1502$

Рефераты:

1) Экспериментальная медицина . . . . . . . . . . . . 940

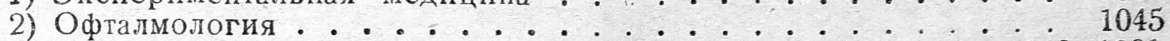

3) Внутренние и нервные болезни ..... $503,(44,1142,1391$

4) Хирургия....110,244,378, 5 5, 645, $92,938,1041,1144,1285$

5) Кожные й венерические заболевания . . $245,247,378,640,935,1043$.

6) Иммунология, серология, бактериология $115,510,634,796,920,1040$,

7) Невропатология . $\begin{array}{rr}1139, & 1506 \\ 801\end{array}$

8) Эндокринология

9) Гинекология и акушерство ................ 63 , 802, 932, 1141

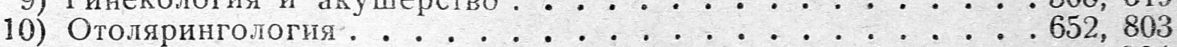

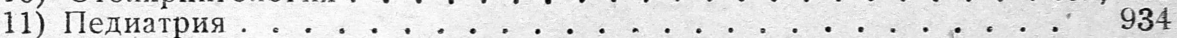

12) Инфекционные болезнй .......................... 1391

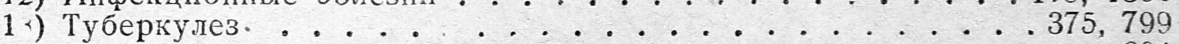

14) Урология

Заседания медищинских обществ:

1) Хирургическое о-во АТССР ......380, 518, 657, 1046, 1048, 1399

2) Казанский филиал акушерско-гинекологического общества . . 515

3) Общество рентгенологов АТССР . . . . . . . . . . . 518

4) Общество терапевтов АТССР ............ 65 7

5) Оториноларингологическое общество АТССР . $\quad . \quad . \quad 653$

6) Казанский филиал общества невропатологов и психиатров . 1398

\section{Съезды и конференции:}

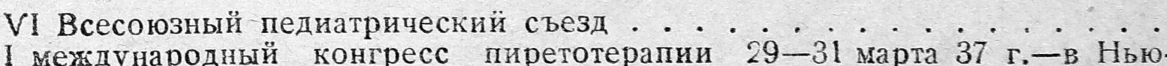
Иорке

XVI сессия Конгресса невропатологов и психиатров Франции и стран французского языка 17-22 мая 37 г.-в Нанси 
Международный терапевтический конгресс 19-21 мая-в Берне . . . .

II международный конгресс спортивной медицины июнь-в Париже . . IX международный конгресс военной медицины и фармации 2-10 июняв Бухаресте

V международный госпитальный конгресс $6-11$ июля-в Париже . . Международный конгресс охраны детства 12-21 июля 37 г.-в Париже . XI международный психологический конгресс 25-31 июля-в Париже . II международный конгресс по переливанию крови в сентябре-в Париже. V международный радиологический конгресс 13-17 сентября-в Чикаго, IV международный педиатрический конгресс 27-30 сентября-в Риме . Международный офталмологический конгресс 1 декабря-в Каире . . . Конференция кумысолечебниц Башкирии . . . . . . . . . . . . . . . Международный терапевтический конгресс $19-21 / \mathrm{V} 1937$ в Берне . . І съезд врачей Армении, III. 1937 . . . . . . . . . . . . . . . . VI Всесогозный съезд физиологов в Тбилиси, 1937 . . . . . . . . . . Интернациональный конгресс акушеров и гинекологов в 1938 г. .
VI съезд международной лиги борьбы с ревматизмом в Оксфорде, $і 1$. 1938 г.

Антиревматическое международное совещание в Париже, 9/X 1937 г. . Международный конгресс по переливанию крови в Париже 29/IX 1937 г. Международная конференция по борьбе с проказой 21/III 1938 г. в

Каире . . . . . . . . . . . . . . . . . . .

Международный конгресс офталмологии 8-14/XII 1938 г. в Каире $\checkmark$ конгресс латинских обществ ото-рино-ларингологии 16/IX 1937 г. в

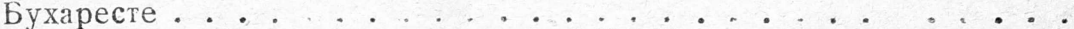
Международный курортный конгресс $3-9 / \mathrm{X} 1937$ г. в Будапеште : $20 / \mathrm{X}$

1937 г. во Франкфурте и Висбадене . . . . . . . . . . . .

\section{Юбилеи.}

115 s

Проф. Д. М. Российский. К 25-летию его науцной, врачебной, педагогической и общественной пеятельности .............

Некрологи.

Профессор И. Г. Гельман. Доц. Арнаутов . . . . . . . . . . . . . . . 863 Памяти профессора Цытовича. В. Громов . . . . . . . . . . . . . . . 660 Проф. В. Н Воробьев. Проф. В. Меньииков . . . . . . . . . . . 1516

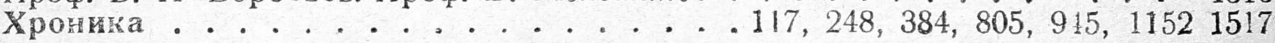
Письма в редакиню... . . . . . . . . . . . . . . 253, 807 Резолющи. Враг под маской советского врача . . . . . . . . . . 809 Приказы . . . . . . . . . . . . . . . . . . . . 946 


\section{ПРЕДМЕТНЫЙ УКАЗАТЕЛЬ.}

Передовые статьи . . . . . . . . . . . . . №№ $6,10,11$

A.

Абортная масса как пластический материал в хирургии 214.

Абсцесс мозга 1150.

Абсцесс верхушки пирамидки височн. кости, операт. лечение его 652 ,-а. легочные 876.

Авитаминозы, их ранняя диагностика 121.

Агглютинация прижизненная, ее роль в терап. эффекте пневмококковой иммунной сыворотки 512.

Адамантинома нижней челюсти 381.

Аденома червеобразного отростка 1136.

Адреналин, его действие на функцию щитов. железы 933.

Acanthosis nigricans, доброкачественный тип 246.

Акрихин 118, 385.

Активная иммунизация против ветряной оспы 61 .

Актиномикоз легких, клиника 1111.

Алергические кожные высыпания после лечения рентгеном 246 ,

Алергия при туберкулезе 1237.

Алергия и проблема эндокардитов 13.

Alopecia areata 246.

Амбулаторные и стационарные диагнозы 25.

Аммиак, его проблема в клинике 222.

Аммиачн, растворы соединен. серебра, их применение по теории д-ра Ермолаева 928.

Амблиопия табачная, лечение ее адетилхолином 1045.

Ампутация по Киршнеру, остеопласт. способ 1044.

Анафилаксия и роль нервн. сист. в сокращ гладк. мускулатуры при ней 899.

Анаәробы, упрощенный способ их выращивания в пластинчатой культуре 346 .

Ангина септическая (агранулоцитарная) и картина крови 1065.

Анимально-вегетативные рефлексы у туберкулезных в процессе эмоциональной мототерапии, их динамика 547.

Аномалия локтевого отростка 1394.

Антиген "Vi“ брюшнотифозной палочки 116.

Антигенные свойства неосальварсана 1126.

Антитела, нейтрализующие вирус свиной инфлюенцы 116.

Антитела к углеводам 1504 .

Антитуберкулезная сыворотка 386.

Аппендикулярный симптомокомплекс при малярии 1499.

Аппендектомия и обработка культи червеобразного отростка 71 .

Аппендициты с инфильтратом 794 .

Аппендициты острые, острые брюшные выпоты и их симптоматология 729 .

Арсен-детоксиновые производные 1041.

Артриты, их лечение рыбъим жиром 1014.

Артюса феномен 21.

Асептика (кажущаяся) и полная стерилизация 374.

Атебрин 385.

Атрезия влагалища с гематометрой и гематосальпинксом 518.

Атуберкулиновый антивирус Мазура 1210, 1226.

Ацетилхолин, лечение им табачн. амблиопии 1045.

Ацидоз беременности физиологический, кетогенный его характер 649.

5.

Бакирово, курорт АТССР, лечение гинекол. больных на нем 616 .

Бактериофаг, 385, - бактериофаг, как терапевтическое средство при дизентерии 561.

Бальнеология и значение в ней $\mathrm{H}_{2} \mathrm{~S} 415$.

Белки, к вопросу о лечебном значении перекармливания ими нефротиков 132.

Беременность и перитонит 1044. 
Бескровное склерозируюшее лечение $505 . \mathrm{g}^{\mathrm{s}}$

Беременность и ее распознавание 1288, маточная и внематочная одновременно 1133.

Библиография травматологическей литературы 253.

Биларзиаз мочевого пузыря с хилурией 1397.

Биопсия при заболеван. грудных желез у женщины 1509.

Бир и его теория о врожденной слабости соединительной ткани 82.

Болезни уха, верхн. дыхат. путей и полости рта 1502.

Болезнь Реклингазена 91, 933.

Болезнь Симмондса, лечение ее гормонами 1506.

Боли в копчике 1393,-родовые и смазывание кокаином половых точек в носу 185.

Ботулизм 1271.

Бремеровская дистрофия и случай обратного перемещения внутренних органов $47 \%$.

Бром, его микродозы при неврозах 305.

Бронхоскопия 654.

Бронхо-эзофагоскопия 352.

Бруцеллез в комбинации с трехдневной малярией 621.

Бруцеллезный ишиас 1076.

Брюшной тиф у вакцинированньх, клиника 954.

Буллезный сальварсанный дерматит 1397.

Бухштаба и Ясинковского реакция, клиническая ценность ее в диференциальной диагностике ревматизма 263.

\section{B.}

Ваготомия и подвижность желудка 1393.

Вакцина гонококковая, опыт "лечения массивн. дозами 921 , и изучение растворим. преципитир. веществ 1040,-противосыпнотифозная 385.

Вакцинация морских свинок и людей против лептоспироза 1512.

Вакцинация против сыпного тифа в Марокко 798.

Вегетативная система, ее нарушения 80.

Вегетативная нервная система и легочный туберкулез 442.

Венозные клапаны, теория их первичной недостаточности 81.

Вены верхних конечностей, их расширение 7 .

Вернейль, его теория о недостаточном функционировании анастомозов 82 .

Ветряная оспа и активная иммунизация против нее $\ell 1$.

Вирус паховой лимфогрануломы 379.

Вирус пузырчатки и дерматита Дюринга 245.

Вирусы и обусловливаемые ими заболевания 796.

Витальная окраска гомологичных органов при введении лизатов 337.

Витмин С 122,- его бактерицидное и антитоксическое действие 636.

Витаминоль, лечение им рахита 280.

Витамины и заживление ран 112.

Влияние пищев. режима на феномен Артюса 1476.

Внутренние болезни и диагностика их 97.

Вну ривенные вливания угля при лечении кожных болезней 947 .

Внутриматочное применение угля в акушерстве и гинекологии 1508.

Внутримышечные инъекции и повреждения нервных стволов при них 590 .

Возбудимость блуждаюего нерва у собак в связи с местным давлением нљ большой мозг при остром опыте 1258.

Возвратный тиф в Калифорнии, изучение его эпидемиологии 1510.

Волчанка 62

Воробьев В. Н. проф., некролог 1503.

Воспаления женской половой сферы и лечение парентеральн. введением минер. вод 1117.

Второй украинский съезд рентгенологов и радиологов 235.

Вульгарная прыщеватость, ее лечение экстрактом мочи беременных 247.

Вывих одной половины таза 1197.

Газовая флегмона 645.

I.

Гали-Валерио и его работа с дизентерии 48.

Гангрена наружных гениталий самопроизвольная 781 . 
Гангрена самопроизвольная, ее иечение плацентарной кровью 215.

Гастриты и колиты, их лечение аммиачными соединениями серебра 152.

Гельман И. Г., проф., некролог 663.

Гемато-энцефалический барьер, его проницаемость на иодист. натрий 1319.

Гемоторакс, к его клинике и цитологии 42.

Генуинная артериальная гипертония, функция щитовидной железы, их связь 1507 .

Гепарин и замедление свертываемости крови 120.

Гепатиты острые и рациональнсе питание при них 142.

Германин и неосальварсан, их влияние на бактерицидность крови кроликов 634.

Герниотомная рана и ранний симптом инфицирования 1342.

Гилроадениты, их рентгенотерапия 857.

Гидроадениты подмышечной впадины, их новый способ лечения 793.

Гинекомастия и цирроз печени 108

Гипертиреоз и гипофизарная корреляция 637 .

Гипертиреоз и дијбет, излеченный тиреоидэктомией 933.

Гипертрофия предстательной железы, этиология 506.

Гиперэргия, локализирование 1143.

Гипноз в хирургии $7<5$.

Гипогликемия менструальная и функциональная дисменоррея 650 .

Гипосульфит, его применение при остром ревматизме 22.

Гипофизарная корреляция и гипертиреоз $(37$.

Гиршпрунга болезнь 1044.

Глютатион в крови при гипер-и гипотиреозах, его содержание 802.

Гнойны : раны и применение гуманоля 182.

Гомеопатия 755.

Гонококк, его выращивание на средах без асцитической жидкости 1371.

Гонорея, диагностика 1043,-и беременность 509,-и лечение его антивирусом 248 .

Гонорея женская, ее лечение аммиачн. растворами солей серебра 861.

Гонорея, к методике ее серодиагностики 247.

Гоноройная офталмия и искусственная лихорадка 248.

Гоноройные артриты, диффер. диагностика 143.

Гонадотропный гормон при лечении муж. стерильности 803.

Гоноройная инфекция, кожн. приба для диагн. 1043.

Гормон половой, его действие 15,5, ,-беременности 60.

Гормональные воздействия на рост грудн. желез и лактацию 638.

Грибовидный микоз 246.

Грип, его лечение 114.

Грипозная проблема по работам сессии Ученого медиц. совета Наркомздрава РСФСР 495.

Грудные позвонки, их перелом и дыхание 111.

Грыжа диафрагмальная, острая ложная 776 ,-легкого травматическая 95.

Грыжи брюшной полости, внутренние, к их казуистике 357 ,-внутренние брюшной полости 28, - Дугласова пространства, ущемленные 49, -мозговые, методика их оперативного лечения 212.

Гуманоль при лечении гнойных ран 182.

\section{A.}

Декомпенсация сердечная и карелевский режим 36.

Дерматит эксперимент. и обмен веществ в печени при нем 640 .

Дерматология и пограничные лучи 641.

Дерматоз беременности 1097.

Дерматомицеты, к вопр продолжит. их жизни 1144.

Десенсибилизирующая терапия 21.

Десенсибилизирующая терапия, ее влияние на клеточковую реакцию организма 1121.

Диабет, лечение 1147 .

Диагноз беременности, химический 649.

Диагнозы амбулаторные и стационарные 25.

Диагностика внутренних болезней, значение осмотра при ней 97.

Диатез эксудативный и лейкоррея 651 .

Диатермия в лечении гипофункции яичников, ее применение 1206. 
Диатермия слизнстой матки при расстройствах менструации 1289.

Дивертикул в простатической части уретры 804,-женской уретры 805.

Дизентерия, вызванная палочкой паратифа В 47.

Динамика рельефа при хронич. воспалениях слизистой желудка в оценке ле. чебного эффекта 1178.

Дискератоз кожи, әксперимент. исследования 1009.

Дисменоррея и смазывание кокаином половых точек в носу 185.

Дисменоррея функциональная и менструальная гипогликемия 650.

Диспансеризация трахоматозных больных 117.

Дистрофические процессы при введении различн. раздражителей в периферич, ветви тройничн. нерва 1014.

Дифтерийные палочки 1460.

Дифтерийный токсин 59.

Дифтерийный токсин-антитоксин, изучение свойств его смесей 510 .

Дифтерия токсическая 53.

Дифгерия, к оценке ее бактериолог. диагностики по методу Фольгер-Золе 908 Добавочные селезенки 507.

Дюпюитреновская контрактура, операция при ней 371.

E.

Египетская дизентерийная эпидемия 48.

M.

Железы паратиреоидные, их функция 114.

Желтуха вегетативно-дискинетическая, клин. иллюстрация к ее синдрому 533. Желтые тела, искусствениое образование их у кроликов 517.

Желудочно-кишечное заболевание и кумысолечение 1058.

Жир рыбий, его действне на бактерии 1042.

3.

Заворот слепой кишки $520,1137$.

Задержание костей плода в полости матки 359.

Задержка менструаций фолликулярным гормоном 1507.

Задержки остатков последа, новый симптом их 649.

Задняя мозговая артерия, к клинике поражения ее ветвей 716 .

Злокачественная иододерма 1144.

Зменный яд и новокаиновый блок по Вишневскому, как метод лечения при отравлении им 6.4.

Илеус острый 648 .

и.

Иммунизация активная, прогив ветрнной оспы 61.

Иммунизадия активная против полимиелита 513,514, -кишечного тракта 510. Иммунитет кроликов к пнеймококку. Роль комплемента сыворотки 511.

Иммунология tiemophilus pertussis 1290.

Ингаляции 655.

Инородные тела пищевода 2 !8.

Инородные тела трахеи и бронхов 1442.

Инородное тело в уретре и мочевом пузыре 805.

Инсулин в терапии пептической язвы 1142 .

Интоксикация при токсической дифтерии 55.

Интравенозная паралдегидовая анестезия 245.

Инфаржты яичка 1146.

Инфантилизм и сахарный диабет 802.

Инфекц. заболевания кожн, их рентгенотерапия 642.

Иррадиадия гипофиза и резистентность к инсулину 114.

Искусственное влагалище из тонкой кишки 518.

Искусственный пневмоторакс и осложнения при нем 87.

Ишиас, его лечение 110.

Камень желудка 1134.

K.

Камень носовой полости 1385,-мочеточнйка 1150. 
Катскиьне ранения 1108.

Кардиальный затвор у человека, графическ. метод иселедования 381.

Кардиты ревматические 16.

Карелевский режим и сердечная декомпеисация 36.

Кардинома придатка яичка, первичная 1396.

Катарры среднего уха секреторные 652.

Кёшинга болезнь 637.

Кислород, его влияние при курсовом подкожном применения 198.

Кислородняя терапия Психозов 299 .

Киста яичника дермоидняя, отшнуровавшаяся 626.

Кисты костные, хирург, их лечение 372.

Кишечная палочка 48.

Кишечная непроходимость и беремениость 750.

Кифоз после столбняка 1383.

Клиника и цитология гемоторакса 42.

Кожевниковская эпилепсия травм. происхождения 580.

Кожные проявления при лейемии 1391.

Колиты и гастриты, их лечение аммиачными соединенияии серебра 152.

Кольпиты трихомонад и их лечение хлорадидом 999.

Конваллен, его лечебное действие при сердечно-сосудистых заболеваниях 259.

Conus medullaris, симптоматология поражений 1025.

Корь, ее вакцинотерапия 1396.

Кормление больных при тастротомии 1494.

Костные опухоли, диагностика 507.

Крапивница, ее излечение аппендектомией 646.

Кровь беременных и паратиреоидный гормон в ней 114.

Кровь плацентарная, ее переливание при раковых заболеваниях матки 1203.

Кровотечение, его остановка влажными шариками 3. 4.

Кровотечения маточные, лечение их ионтофорезом 517.

Кровотечение носовое, его остановка 113.

Кругооборот крови у сердечно-сосудистых больных, клиническое значение определения его скорости 255.

Кругооборот крови, клин, наблюд. над его скоростью при помощи внутривен. вливания хлористого кальция 824.

Ксантома 112.

Культя слепого отростка толстой кишки у собак, әксперим. данные о судьбе погруженной и непогруженной культи 332.

Кумыс, его влияние на моторную функцию желудіка 675.

Кумысолечебницы Башкирии 383.

Кумысолечение при желудочно-кишечн. заболев. 1058.

Јабильность сыворотки крови 510.

ก.

Легочный рак у углекопов 1419.

Лейкоррея и әксудат. диатез 651 .

Лечебная сыворотка для пневмококковых пневмоний V типа 798.

Лечение ран по Löhr'y 1287.

Лиенолизатотерапия при tbc, теорет. основания к ее испытанию 347.

Лизатотерапия при заболев. нервной системы 1081.

Лизатотерапия при кожн. болезнях 1090.

Лимфогранулома паховая, ее вирус и пах. лимфогранулематоз $3: 9,380$.

Лимфогранулематоз в Бадене 503.

Lipiodol 1044.

Lithopädion четырехлетней давности 782.

Лихорадка паппатачи, ее нервно-психическ. явления 1312.

Лишай чешуйчатый и его лечение внутривен. вливаниями гиносульфита 973. Лучистая терапия при новообразованиях 1287.

\section{M.}

Мазки ири дифтерии, их повторное исследование 1396.

Мак Клюра" и Альдрича проба 22.

Малярийная гемоглобинурия, ее леченйе С-витаминовой кислотой 1391. 
Малярнйные поражения пернфернческой нереной системы 566. Малярия трехдневная и бруцеллез 62?, - хемотерапия при ней 503. Масса кровн ири малярин О47.

Mactur, ero merenне 1509.

Матка послеродовая, обследованте се полости 731.

Медиастннт гионый при перфорацни пищевода, его самодренирование Медицинская кровать для предупреждения и лечения пролежней, тантрены и дия облегчения состояния больных 1267.

Медицннская профконсультация 1.

Мелореостоз 111.

Менннгит, вызванный мнкроорганизмом группы Salmonella 1342

Ненингит, вызваниый палочкой паратифа 1392.

Менингит, вызваныый нафекцией Br. abortus bovis 931.

Менструальные расстройства, лечение 518.

Менструацин, о задержке их фолликуляным гормоном 1517.

метаболиты, их роль и роль гисто-гематических барьеров в регуляиии функцин̈ организма 391.

Методика фұнкультерапии заболеваний органов двнжения в условия станионара 1184.

Миарсенол при теченни сифилиса 1102.

Молозный режим при сердечной декомпенсацни 26.

Морская болезнь ін испытания сердечн. сосудист. системы у лиц, подверженных ей 1407.

Морфий, его применение после операций в брюшной полости 244.

Морфологнческий состав кантаридинового пузыря при алергіческих состояниях, клин. значение его нсследования 554.

Музыка и операция 374.

H.

Невро-вегетативные явления со стороны печени 665.

Неврозы н мнкродозы брома 205.

Неврологические расстройства при беременности 1510.

Недержание мочи ночное, лечение его поварен, солью 924.

Нейфельда реакцня н определенне типа пиевмококков 115.

Некроз тканей после местной анестезин новоканном 325.

Неосальварсан и германин, их влиянне на бактерицидность крови кроликов 634. Непроходимость кишечннка, врожденная 1148.

Углекислые (нарзанные) ванны, нх влияние на изменение кол-ва циркулир. крови 408 .

Нервная система, ее болезни и их физиотерапия 109.

Нефрозы, к их патогенезу и клинике- 126.

Нефролнтиаз двусторонний, в сочетании с двусторонним гидронефрозом 518.

Новоканновый б̆ок по Вишневскому как мегод лечения отравления змеинми Ядом 0 \}.

Новокаиновые инъекции, результаты лечения ими 165.

Носовое кровотеченне и его остановка 113.

Носовые нервы, их строение 804.

0.

Обезболивание на фронтах 37 ;.

Обезболивание нормальных родов 516

Обезболивание родов в начале пернода раскрыгия 610 .

Обморожения и их лечение без перевязок 84.

Обработка перчаток антисептнческая 870.

Ожирение, его диэтическое и гормональное лечение $63 \%$

Ожоги фосфорные, лечение 648.

Озена, ее лечение 864.

Oперативная фиксапня позвоночника 1286

Orepanня Cotte 1289.

Определение срока родов 1289.

Oпределение степен раскрытия маточного зева при родах приемом Schatz

Unterberger'a $5 ! 7$.

Оптнко-механический завод в Татарин 117. 
пухоли, влияние эстрнна на нх рост 115.

Опухоли позадибрюшинные зиокачественные 1145.

Опухоли, их симптомотология 5.8 .

Опухоль мозга и воспалит. реакция 801.

Органы б;юшной полости, их закрытые повреждения 778

Осарсол н леченке им сифилиса 67.

Осмовной обмен при серд-сосуд недостат, 81 .

Оспа ветряная и активная, нммунизация против нее 61.

Остеодистрофия фибрсзная 91

Остеомиелит челюсти, лечение его стафилококковым апатоксином 244.

Остеониелит гематогенный у детей и травма 1073.

остеомиелиты гематогенные острые, их консервативное лечение 793.

Остеомиелиты хронические, опыт их лечения по Лэру 323

Остит генерализованный фиброзный, его течение 505.

Ostitis fibrosa cystica localisata 1336.

Острая спонтанная инфекция нервной системы 71 .

Острын̆ ревматиз: 13.

Острый ревматизм и лечение его стрептоцидом 1304.

Отнт мукозный острый 653.

Ото-офталмоневрологня, ее общне шроблемы и роль внсочной доли 3 и.

ก.

Панкреатит острый, его клиннка и лечение 885.

Папилломы и карциномы мочевого пузыря у рабочнх красочн, промышл. 1396. Парагормон 932.

Паралич кишок, послеоперационный, лечение 373.

Паратиреондный горнон в крови беременных 114.

Паратнф В и днзентерия, вызванная его палочкой 47.

Патогенез, клиника и лечение послеродов. лактационного мастита 1504.

Первнчная карцинома женской уретры 85.

Первичный туберкулез мышц 1288.

Первый съезд врачей Армении 384.

Переливание крови в клинике детских болезней 693.

Переливание плацентарной крови 1149.

Переливание плацентарной крови прн раковых заболеваннях матки 123.

Переломы бедра у детей $€ 48$

Переломы со смещеннем шейных позвонков 1044.

Перелом грудных позвонков и дыхание 111.

Перелом большеберцовой кости. Метод внутрикортикального соединения костным клином 507.

" Перелом ладьевндн. кости запястья, изолированный 1431.

Переломы тазового кольца и вывих одной половины таза 1197.

Переломы шейки бедрл, их лечение 112

Переломы пяточной кости, лечение их 371 .

Переломы большеберцовой кости задние маргинальные, сравн. оценка способов их операт. лечения 891.

Пересадка мочеточников в кишку, техника еe 328.

Перитонит и беременность 1044.

Перкаин 373.

Перфорация язвы желудка при рентгеноскопии 988.

1Іерфорации желудка и 12-перстной кишки 794.

Печень, резекция ее доли 67.

Печень, ее резекция поо поводу ракового метастаза 111.

Пиелография при вдохе и выдохе 794.

Пижо, его теория о расширении вен 8 ?

Пиодермин, их лечение лучистй әнергией искусственных источников света 291.

Пирамидон и его действие 20 .

Pyrethrum - дерматит 25.

Плазмохии 385 .

Плазмодид, влияние его токсических доз на нервную систему 576 ,

Плазмоцид, случай повышенной чувствнтельности к нему $118,285,492$.

Плевральные срашения 800 . 
Питрессин при вздутии кишечника 1391.

Пластика губы 1150.

Пластическая индурация члена 805.

Пластический способ восстанов ения заднего прохода 1286.

Плеврит гнойный 916.

Плеврит геморагическ. 913.

Пломбирование при туберкулезе легких 111.

Пневмококковая сыворотка, ее действие в организме 930.

Пневмококки, быстрое определение их типа при помощи реакии Нейфельда 115.

Пневмонии детск. возраста и их изучение 959.

Пневмоторакс искусственный и осложнения при нем 87.

Повреждение кисти и пальцев, и лечение их рыбьим жиром и гипсовой повязкой 1288.

Повреждение черепа в состоянии опьянения 1387.

Повреждения медия̊льной боковой связки коленного сустава 1287.

Поджелудочная железа, ее острые заболевания после огерации на желчых путях 139 ?.

Полисахариды дрожжей 931.

Половой гормон, анализ его действия 1505.

Положение головщи плода в полости таза, простейш. способ́ его определения $62 \uparrow$.

Помутнение стекловидиого тела, его дечение переливан. крови 1472.

Почки, их поражение при дифтерий 57.

Применение наружн. поворота при ягодичном предлежании 1035.

Прогрессирующий некроз кожи 1395.

Протез ткани роговицы 248.

Профконсультация медицинская 1.

Pruritis, лечение 5 '0.

Pruritus vulvae его лечение 1508.

Псевдоартроз, излечение его инфекцией 506.

Псевдожелтуха 118.

Психозы, их кислородная терапия 299.

Психозы малярийные 449.

P.

Разрывы малярийной селезенки 976.

Рак пищевода, клиника 480.

Рак на люпозном осиовании 1150,-женской уретры, лечение 1509.

Рак прямой кишки, урологические осложнения при нем 508.

Рак прямой кишки и рентгеновское его исследование 1394.

Раны инфицированные и рыбий жир 112.

Расстройства овариально-менструальнго цикла, опыт лечения их моџей беременных 516.

Рахит 123.

Рахит детей, его профнлактика и лечение 680.

Рахит, его лечение тюленьим жиром 64.

Рахит, его лечение витаминолем 280.

Рвота беременных, ее лечение аскорбиновой кислотой 1508.

Реяктивность кожи сенсибилизированньх животных на воздействия микроорга= Низмов 124).

Реакци кожных капилляров на травматизацию при заболев, внутрен, органов, исследование 1291.

Реакция Бухштаба-Ясиновского у детей ревматиков и ее диагностическое значение 685.

Реакция отклонения комплемента при инфлюенце 799.

Реакция Бусканно при внутр. заболев. 811.

Реакция Таката-Ара 505.

Ревматизм в детском возрасте 1284.

Ревматизм хрон, и паратиреондэктомия 933.

Ревматические пульмонить у детей 1448.

регенерация костной ткани 470 . 
Резекции желудка (437) по поводу рака 507.

Резекция печени по поводу ракового метастаза 111.

Резистентность к инсулину и иррадиация гипофиза 114.

Реинфекция в скарлатинозн. больницах, как причина остожнений и рециди. вов 1511.

Ректидон в ортопедии 373.

Рентгеновский аппарат, изобрет. врачем Бувэрс 249.

Рентгенотерапия 12-перстной кишки 268.

Рентгенотерапия гипертиреозов 1287.

Рентгенотерапия хроническото грипа 274.

Рефлексы, вызываемые давлением на нервные стволы при зклямпсии и презклямпсии, их значение 509.

Рнно-ларингоотиатр. конференция Поволжская 3-я, 629.

Ринопластика, новый метод 1145.

Риносклерома, ее осложнение эпителиомой 843.

Ритм дыхания, его расстройства при остром повторном кровотечении 191.

Российский Д. М., проф., к его 25-летнему юбилею 251.

Рыбий жир, его действие на течение инфицированных ран 112.

C.

Самоампутация червеобразного отростка слепой кишки, двойная 356.

Самонаблюдение врача над старостью 1021.

Сарнбикуловские сероводородные ванны 429.

Саркомы колен. сустава 1045.

Свищи хронич., их лечение медн. купоросом 647.

Селезенка, ее подкожные разрывы 452.

Сенная лихорадка, ее рентгеновское лечение 503.

Сенсибилизация организма 14.

Септическое заболевание, вызван. В. proteus 1491.

Сергиевские минеральные ванны, их влияние на проницаемость капялярных сосудов кожи и гидрофильность ткани 424.

Сердечная декомпенсация, ее лечение видоизмененным Карелевским режиMOM 36.

Серодиагностика tbc сыворотки морской свинки и ее значение для эксперим. изучения tbc 635 .

Серологическая специфичность патологически измененных тканей органов 634 ,

Сибирская язва, химич. и иммунолог. изучение механизма инфекции 1289.

Сильвиев водопровод, его сужение на почве опухоли 644.

Симметрическая кератодермия и вегетативная нервная система, ее изменения 1381.

Сирингомиелия, к клинике ее 363.

Сифнлис, роль его в заболеваниях носоглотки 1397.

Сифилис и переливание крови 1398.

Сифилис и беременность 1398.

Сифилис легких, ранний врожденный 1028.

Сифилис и эксперим. изучение иммунитета при нем 1012.

Сифилис, его лечение осарсолом 67.

Сифилис мозга и сиф. атрофия мозжечка 645.

Сифилис, заражение им при перелив. крови 919.

Сифилитический Ішанкр влагалища 1397.

Скаленотомия при лечении верхушечных каверн 801.

Склеродермия прогрессивная 1144.

Склерозирующее лечение водянки яичка 1397.

Скорбут 123.

Случай пласпики сальником при поврежлении поджелудочной железы 1030.

Случай перекручивания фиброматозной матки 1032.

Смертность, ее процент при дифтерии 5 .

Соли желчных кислот в борьбе с инфекцией 113.

Солитарные кисты почек 1331.

Sohaceloderma 2.6.

Спинномозговая жидкость, при коклюще, ее изменения 1395.

Спинномозговая анестезия перкаином 373.

Спирт, его влияние на бактерицидную силу крови 116. 

Спнрохета бледная, реакция связввзния компленента на енфилис с ее экстрак-
том 7f9.

Спирохеты 68 .

Спленопатин, нх гирург. и терапевт..лечение 1285.

Станнонарные н амоулаторные днагнозы 25.

Стафилококковый анатоксин, дечение ны остеомиелита челюсти 244.

Стафилококки и нх связь с пишевыми отравлениями 1512.

Стерилнзащия мужчин ненщин, показания к ней 118.

Стерилизация инструментов 796.

Стрептококки патоген. для человека, взаимозависиность яежду их вирулентьо. стью и фибрннолитической способиостью 920.

Стоматит н ангина Вен-Сан-Плаута 967.

Cтрептококк зеленый 1041 .

Cтрептоинд 118.

Стрептотрнхоз, его значение в хирургин 110.

Стригущий лншай, новый способ его лечения 210

Стриктуры мужск. уретры после применения хлорист. цинка 804.

Сыворотка, ее дейстие иа денервиров. лапку 904.

Сыпной тиф, изучение механизма иммунитета прн нем 515.

Сыпной тиф эндемнческнй у полев. мыши 1510.

Сынной тнф, вакцннация против нето 1510.

\section{T.}

Творог, применение его для основной питательной среды при выращивании микробов 342.

Теория хемоцепторов 930.

Терапня заболеваний тнфозной групиы 113.

Терапия десенснбилизируюшая 21 , протенновая 15.

Термопара для исслед. Кожной температуры методом Гальванометрин 620 .

Тимус-снндром у новорожденных 115.

Тиреондоэктомня при базедовнческой аснстолин 802.

Тнреотокскко3, снмметр. Заболев. кожи алерг. типа прн нем $є 37$.

Тнреотоксикоз эксперик, его пат.-анатом. картина 802.

Тиреотоксикозы н Базедова болезнь 1142.

Тиф, его лечение специфической сывороткой 1392.

Тиф, его лечение неоарсфенамином и дегидрохлоратом натрия 1391.

Тнф возвратный в Калнфорнии, изучение эпидемиологии его 1510.

Тифозная группа заболеваний, ее терэпия 113.

Тифоподобные заболеван. с палочкон Гертнера в крови 1424.

Токсин дифтернйный 59.

Томограф первый советский 1376.

Товинамбур в диете диабетика 1308.

Токсическая пифтерия, ее клиника и лечение 53.

Tt. brucei н действне лекарств. веществ 931 .

Траваы спнниого мозга, клиника 1496.

Трансфузия крови прн кожн. заболев, 849.

Трипанозомная ннфекция кроликов, спонтанная, апатогенная 635.

Трихлоруксусная кислота, ее применение при послеоперационных свищах в урологин 375 .

Тромбоз и эмболия; их профнлактнка н лечение 1287.

руберкулез и остеомиелит сочленений тазового кольи 1394 ,-легких и пломбирование при нем 111 ,-мыши первичный 792.

Туберкулез у детей и его ннфильтративные формы 702,-легочный и вегетативная нерьная система 442,-Костно-суставной, его лечение 596, - серодиатностнка его н вотчанка 379.

Туберкулез кожный, бессолевая днета при нем $378,-$-легочный, новые пуги хирургической коллапсотерапии 377 ,-легочный, значение пневмоперитонеума в его лечении 378 , легочный,- новая орнентация в его климатотерапии $377,-$ - кспериментальный костный и костно-суставной у кролика 376 , легочның, общке критерни его классификацин 376.

Туберкулез открытый, прогноз и рентабельность методов лечения 375 , поозвоиочинка, ранние симптомы заолевания 1428. 


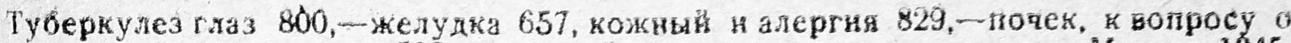
симптоматологин 508 - костнй н лечение его антивнрусом Мазура 1345.

туберкулезия зтнология узловатой эритемы, экспернм. подтверждение 801.

Туберкулезное поражение правпго груднноключниного сочлененна 519.

Туберкулезные бацнллы, продолжительность их жнзнн в мокроте 116.

Туберкулезнье бациллы, их типы в свете учения одиссоциации 759.

Туберкулезный процесс, лабораторная дкагностнка ега актнностй 42.

Туберкулинотерапия у детен, эндоназльнын -метод 1457.

Туляремическая пневнония 504.

Тюлений жир, леденне нм рахита 64

y.

Уголь, внутриматочиое его применение в акушерстве и гниекалогни 1308.

Уретропеле, диверткиу уретры, субуретральний абсцеес у жениин 1397.

Урологическай нсесоюзная конференция 499.

Феномен нитерференцин 930

(⿻)

Феномен Циварцмана 1358.

Феномен Бордэ, к вопросу о механизме 1364.

Феномен Артюса 21, 1476.

Феномен Чейн-Стокса и его отношение к др. расстройствам рияна дықания $10,2$.

Ферменты окислительные н пищеварение 505.

Фиброзная остеодистрофия 91.

Фиброид основания черепа, лучнстая терапия 803.

Фибромиомы маткн, их хирургическое леченне 458.

Фибромномы матки, их радикальное лечение $740,744,749$.

Физнко-хнм. н биолог, явлення, их условия в поле ультрлкорогких воли 896.

Фнзиотерапия болезней нервной системы 109

Физиотерапия ран 784

Фнльтрованиые, ультрафнолетовые лучн и применение их при лапаротемияд 1394.

Фолликулин при свнщах грудной железы и мастнте 509.

Фурункулез и леченне его внтамнном А 1288.

фурункулы лица, нх леченне 795.

Хемотерапия при малярни 503.

$x$.

Химиотерапия рака 1505.

Хнмнотерапия қокковых заболеваний 1143.

Хнмизан крови" при болезни Педжета и гнперпаратиреоз 932.

Хирургіческая етруна 176.

Хлорацнд 211.

Хорея рецнднвир. в связи с введен. противоднфтер. сыворотки 924.

Хорнонэпителнома 463.

Хронносепсис,- как причнна тромбоза нижней полой вены 366

Хроннческие абспесы грудной железы 1436.

Цнбальгин 373.

4.

Циститы и их лечение хлорацндом 994.

Cystoadenoma papillaris renis 518 .

Читология и клиника гемоторахса 42.

Цытович проф., некролог 6 6?

U1.

Шейа бедра, леченне ее переломов 112.

Нига-Крузе, дизентерийная палочка, 49.

U1.

Щнтовндная железа, ее рентенотерапия при сердечн. недостатөчности 8)3.

ЦЦитовидная железа и беременность 1289.

Щитовидная железа, кожная $\mathrm{T}^{\circ}$ прн ее заболеваннях 638. 
Экзена" от одежды 641.

Экзематозные изменения кожи, нх влияние на надпочечникн 641 .

Экзопернкардиопексия 1145.

Экетракты аскарнд и кожа 642.

Электро-тино-лизатотерапия при Баледовои болезни и гипергиреозах 439.

Электрокардиограмма при хирургическом обезболивании 793.

эмболектомия и ее отдаленные результаты 112.

Эмболин венечных сосудов 1173.

Эмболия н тромбоз; нд профилактнка и лечение 1287.

Эндартериит, ревматическая его этиология 1051

Эндокардиты, их проблема в связи с учснием о6 алертии 1319.

Эндометрнозы, клиннка 1509.

Эндоскопня при заболеваниях легкнх 799,

Энтеротропные инфекцин, методика борьбы с ними 387.

Эниефалитики хронические н општ лихорадочной терапии 162.

Эпидемнология эпидемической вәдянки 1512.

Эпидемнческий менинги, опыт применения моновалентных сывороток в его терапин 155.

Эпидемический энцефалит, способ заражения 1512.

Эпидемический энцефалит в Японии 798.

Эпидермофнтия 836.

Эпилепсия, значение травмы в ее развитии 580.

Эрготизм 1503.

Эрозии шейки матки и их лечение рыбьин жиром 1119.

Эссенциальное недержание мочи, применение сернокис. магнезии для его лечення 866.

Эстрин, его влияние на рост опухолей 115.

Эхинококк брюшной полости, диссеминированный 1148.

Эхинококковая киста, после эхинококкотомии 488.

Эхинококк левой почки 925.

Эфирные клнзмы прн коклюше 1395.

Язва желудка 506,1392

Язва желудка и двенадцатиперстной кишки, прободная 170.

Язвы голени, хроническ. и ртутн. пластырь при их лечении 922.

Язвы желудка и 12-перстной кишки и результаты их хирургического лечения 317.

Язвенная болезия и морфологическая конституция 149.

Язычны这 306484 . 
3.

Экзена от одежды 641."

Экзематозные изменения кожи, нх влияние на надпочечники 641.

Экзопернкардиопексия 1145.

Экетракты аскарнд и кожа 642.

Электро-тино-лизатотерапия лри Баэедовоц болезни и гипергиреозах 439.

Электрокардиограмма при хирургическом обезболивании 793.

эмболектомия и ее отдаленные результаты 112.

Эмболин венечныд сосудов 1173.

Эмболия н тромбаз; нд профилактнка и лечение 1287.

Эндартериит, ревматическая его этиология 1051.

Эндокардиты, их проблема в связи с учснием о6 алертии 1319.

Эндометриозы, клиннка 1509.

Эндоскопня при заболеваниях легкнх 799,

Энтеротропные инфекцин, методика борьбы с ними 387.

Эниефалитики хронические н опыт лихорадочной терапии 162.

Эпидемнология эпидемической водянки 1512.

Эпидемнческий менингт, опыт применения моновалентных сывороток в его терапин 155.

Эпндемический энцефалит, способ заражения 1512.

Эпидемический энцефалит в Японии 798.

Эпидермофнтия 836.

Эпилепсня, значение травмы в ее развитии 580.

Эрготизм 1503.

Эрозии шейки матки и их лечение рыбьия жиром 1119.

Эссенциалное недержание мочи, применение сернокис. магнезии для его лечення 866.

Эстрин, его влияние на рост опухолей 115.

Эхинококк брюшной полости, диссеминированный 1148.

Эхинококковая киста, после эхинококкотомии 488.

Эхинококк левой почки 925.

Эфирные клнзмы при коклюще 1395.

ค.

Язва женудка 506, 1392.

Язва желудка и двенадцатиперстной кишки, прободная 170.

Язвы голени, хроническ. и ртутн. пластырь при их лечении 922.

Язвы желудка и 12-перстной кишки и результаты их хирургического лечения 317.

Язвенная болезй и морфологическая конституция 149.

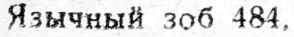


В. С. Петерсон и Б. К. Рубашкина (Саратов), Случай септичесжого заболевания, вызванного b. proteus .

В. А. Макаренко (Ростов на/Д), О кормлении больных при гастростомии. 1494 Доц. Р. Я. Будина и М. В. Гольдельман (Киев). К клинике травм спинного мозга.

А. А. Шкляев (Челны), О так называемом „аппендикулярном симптомокомплексе\& при малярии.

Обзоры, рецензии, рефераты и пр.

Проф. А. Денкер, проф. В. Альбрехт. Учебник болезней. уха, верхних дыхательных путей и полости рта. В. Громов.

Рефераты: а) иммунология; б) эндокринология; в) акушерство и гинекология; г) эпидемиология.

Проф. В. Н. Воробьев. І. Проф. В. Меньшиков. . . . . . . . . . . 1513

Хроника.

В ближайшее время выходи т из печати и будет разослан П О П И Сч и К М ТОМ .ТРУДОВ КАЗАНСКОГО ГОС. МЕДИЦИНСКОГО ИНСТИТУТА эа 1937 г.

В томе помещены следующие работы: 1) проф. В. Н. ТЕРНОВСКИй, „Ави ценна, его жизнь и труды в области биологии и медицины (к 900-летию со дня смерти). 2) А. М. МЕЩЕРЯКОВ, „К морфологии парасимпатического отдела вегетативной нервной системы тазового сплетения человека и некоторых животных“. 3) В. Н. МУРАТ, „Опыт экспериментально-морфологического анализа нервных окончаний в поперечнополосатых мышцах глаза“. 4) И. Ф. ХАРИTOHOB. „В вопросу о кровоснабжении симпатической нервной системы человека“. 5) И. Н. МАТОЧКИН. „К вопросу о высоком отхождении артерий предплечия у человека".

В 1938 году будет издано четыре выпуска, до 20 печ. листов каждый. Стоимость одной книги 5 руб., т. е. 20 руб. в год з а ч т тр е вы пу к к.

В первом вып ске за 1938 г. будут помещены статьи:

1) РАСПОПОВА, „О возможности замены кураре сернокислой магнезией В опытах со стрихнином». 2) КАНДАРАТСКИЙ, „Состояние нервной системы матки при раке и фибриллярная структура раковой ткани“. 3) МУКОСЕЕВА „К гистопатологии и патогенезу острых и хронических мастоидитов“. 4) РОТШТЕЙН, „Неспецифическая аллергия и әкспериментальная гонококковая инфекция". 5) ОЛЕСОБљ, , Лсчение рахита советским препаратом витамина Д“. 6) КАСАТКИНА, „К вопросу о косвенном определении малых количеств калия в присутствии большого К̈оличества натрия“. 7) АДО, „Материалы к учению o гиперэргическом воспалении Aithus'a".

Подписку на „Труды КГми“ и заказы на отдельные книги следует направлять: г. Казань, редакции „Казанского медицинского журнала“. 


\section{ОТКРЫТА ПОДПИСКА}

HA

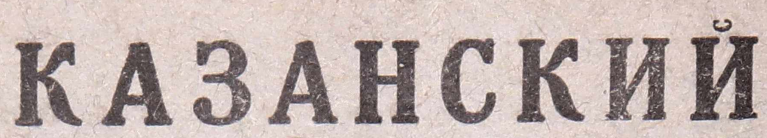

МЕДИЦИНСКИЙ ЖУРНАА

ИЗДАНИЕ СОВЕТА ФИЛИАЛОВ НАHА 1938 ГОД УЧНЫХ МЕДИЦИНСКИХ ОБЩЕСТВ ТАТАРСКОЙ АССР

(Год иӟдания XXXIV)

Орган Азанского медицинского института и Казанского института усовершенствования врачей им. В. И. Л енина.

„Казанский медицинский журнал" содержит следующие основные отделы: 1. Социалистическое здравоохранение, социальная гигиена, профгигиена и профпатология; II. Теоретическая и клиническая медицина; ILI. Краткие сообщения из практики; IV. Обзоры по наиболее интересным и важным для врача вопросам, рефераты важнейших работ из заграничной печати, рещензии и библиографические заметки о вновь выходящих медицинских книгах, отчеты о научных командировках, о главнейших врачебных съездах, о диспутах при защите диссерт́аий, о заседаниях медицинских обществ Казани и др. гор. СССР; хро. ника медицинской жизни в СССР и загранищей; вопросы, ответы и объявления.

Журнал выходит өжемесячно книжками, до 9 печ. листов каждая.

\section{ПОДПИСНАЯ ПЛАТА С ДОСТАВКОЙ И ПЕРЕСЫЛКОЙ}

На год (12 №Na)-15 руб.

На $1 / 2$ года (6 №№) -7 р. 50 к.

ПОДПИСКА ПРИНИМАЕТСЯ ВО ВСЕХ ПОЧТОВЫХ ОТДЕЛЕНИЯХ

Можно также направлять подписку по адресу редакции:

г. Казань, редакция „Казанекого медицинского журнала“. 